Universidade de São Paulo

Faculdade de Filosofia Letras e Ciências Humanas

Departamento de Letras Modernas

FRANCESCA NUTI PONTES CRICELLI

\title{
DIÁLOGOS EM TRADUÇÃO:
}

Cartas a Bruna de Giuseppe Ungaretti

São Paulo

2019 
Autorizo a reprodução e divulgação total ou parcial deste trabalho, por qualquer meio convencional ou eletrônico, para fins de estudo e pesquisa, desde que citada a fonte.

Catalogação na Publicação Serviço de Biblioteca e Documentação Faculdade de Filosofia, Letras e Ciências Humanas da Universidade de São Paulo

$\mathrm{Cd}$

Cricelli, Francesca Nuti Pontes

Diálogos em Tradução: cartas a Bruna de Giuseppe Ungaretti / Francesca Nuti Pontes Cricelli ; orientador Mauricio Santana Dias. - São Paulo, 2019. $504 \mathrm{f}$.

Tese (Doutorado)- Faculdade de Filosofia, Letras e Ciências Humanas da Universidade de São Paulo. Departamento de Letras Modernas. Área de concentração: Língua, Literatura e Cultura Italiana.

1. Ungaretti. 2. Poesia. 3. Tradução. 4. Cartas. 5. Teoria Literária. I. Dias, Mauricio Santana, orient. II. Título. 


\section{FRANCESCA NUTI PONTES CRICELLI}

\section{DIÁLOGOS EM TRADUÇÃO: \\ Cartas a Bruna \\ de Giuseppe Ungaretti}

(versão corrigida)

Tese de Doutorado apresentada ao Departamento de Línguas Modernas da Faculdade de Filosofia, Letras e Ciências Humanas da Universidade de São Paulo para a obtenção do título "Doutora em Letras", no programa LETRA (Línguas Estrangeiras e Estudos de Tradução).

Orientador: Prof. Maurício Santana Dias

Candidata: Francesca Nuti Pontes Cricelli

São Paulo 

Nome: CRICELLI, Francesca Nuti Pontes

Título: Diálogos em tradução — Cartas a Bruna de Giuseppe Ungaretti

Tese de doutorado apresentada à Faculdade de Filosofia Letras e Ciências Humanas da Universidade de São Paulo para obtenção do título de Doutora em Letras.

Aprovado em:

Banca Examinadora

Prof. Dr.

Instituição:

Julgamento:

Prof. ${ }^{a}$ Dr. $^{a}$

Instituição:

Julgamento:

Prof. ${ }^{a}$ Dr. ${ }^{a}$

Instituição:

Julgamento:

Prof. ${ }^{a}$ Dr. ${ }^{a}$

Instituição:

Julgamento: 
Às minhas ljósmaður, mães de Luz:

Paula, Ana Rita e Myrthes. 


\section{AGRADECIMENTOS}

Nos meses em que preparei a curadoria para uma exposição em homenagem à presença da poesia italiana em São Paulo, na Casa das Rosas, escrevi um poema que apontava um processo de condensação de experiências, tanto pessoais quanto curatoriais, mas, sobretudo, uma espécie de diálogo íntimo com um verso de um poema de Ungaretti. Aproprieime do seu verso e usei-o para arrematar meu poema. Tudo isso ocorreu muito antes de que eu descobrisse as cartas que o poeta dedicou à sua amada Bruna Bianco. Usei um verso que dizia da necessidade de se manter uma distância feito a que se tem diante de um espelho: imaginava que, muito perto, perdia-se a visão refletida e, distante demais, incluia-se no recorte muitos outros elementos. Distanti come in uno specchio. Descobrir o arquivo, pesquisálo, traduzir e escrever esta tese foi a experiência mais radical que já vivi, tanto intelectualmente como emocionalmente. Foi nesta perlaboração que descobri a verdade sobre o primeiro verso do poema escrito por mim - é uma longa estrada repatriar a alma. A alma errante do poeta e o enigma da poesia foram os faróis de luz emanados por Ungaretti que há muito tempo venho seguindo. Para chegar aqui, devo reconhecer e agradecer a todos que, de alguma forma, me guiaram, me deram a mão, me abraçaram.

Bruna Bianco, por ter confiado a mim a honra e o prazer dessa transcrição, por ter decidido abrir o baú de cartas, me contar suas memórias mais queridas e íntimas, por termos sido confidentes durante esses anos de transcrição. Por ter me apresentado o seu Ungà, outro e também o mesmo do que conhecia por poemas e ensaios. Sua filha Anna Maria, seu genro Daniel, seu filho Francesco, seus netos Lorenzo e Francesca.

Agradeço também à Universidade de São Paulo, pelos anos de ensino público e gratuito, ao Departamento de Letras Modernas, pelo apoio e pela presteza, à Coordenação de Aperfeiçoamento de Pessoal de Nível Superior (Capes), pela bolsa concedida que possibilitou a realização desta pesquisa.

Ao Prof. Maurício Santana Dias, meu orientador, a quem devo o incentivo por ter abraçado esta pesquisa e trazido-a para dentro dos muros universitários. Desde a época da exposição na Casa das Rosas, sua dedicação, sua amizade e sua experiência foram presentes inestimáveis para mim. Tenho aprendido, de fato, os ossos do ofício da tradução literária com a prática e com o diálogo riquíssimo que me proporciona sua presença, seus corajosos incentivos. 
À Prof. ${ }^{a}$ Lucia Wataghin, por ter me recebido na USP durante a época da produção da exposição na Casa das Rosas, por ter me aberto a sua extensa e rica reserva de saber literário, sua expertise ungarettiana. Por ter participado do meu exame de qualificação apontando caminhos e melhorias, por ter visto em mim a paixão pelo nosso poeta e ter acreditado nela muito antes que as cartas para Bruna atravessassem meu caminho. Também agradeço por ter me acolhido no Grupo de Estudos e Pesquisas em Literatura Italiana e Tradução da USP.

Aos amigos Davide Rondoni e Antonio Riccardi, pela presença e por me encorajarem desde o início no abraço desta pesquisa e no meu caminho como poeta e tradutora. À Luisa Finocchi, da Fondazione Mondadori, por todo o apoio.

Ao Prof. Álvaro Faleiros, por ter participado do meu exame de qualificação e ter apontado com simpatia qual era realmente a minha questão que se sobrepunha a todas as outras, saltando entre as linhas. Ao Prof. Yuri Brunello, pelo curso proferido na USP sobre Ungaretti e Montale tradutores, por ter aberto um diálogo amistoso sobre estas questões, por ter estado presente em minha banca de defesa, por sua inestimável e genial contribuição e por fazer com que meu pensamento vá além do que está escrito. Ao Prof. Murilo Marcondes, pelo curso proferido com a Prof. ${ }^{a}$ Lucia Wataghin, especialmente por ter discutido a relação de Ungaretti com Murilo Mendes, suas traduções e ter mostrado sua preciosa edição de Finestra del Caos aos alunos. À Prof. a Prisca Agustoni, por aceitar estar nesta banca e pelo fértil e rico diálogo poético e tradutório deste viver entre-mundos. À professora Maria Betânia Amoroso, por sua preciosa contribuição e instigantes provocações durante a defesa. Aos profesores do nosso antigo programa Tradusp com quem tive maior contato, Prof. João Azenha, Prof. John Milton e as professoras com quem pude trabalhar na CPG: Prof. ${ }^{a}$ Luciana Carvalho, Prof. ${ }^{a}$ Heloisa Cintrão, Prof. ${ }^{a}$ Adriana Zavaglia, Prof. ${ }^{a}$ Ângela Zucchi. À querida Edite dos Santos Nascimento, secretária do nosso departamento, pela dedicação, carinho e atenção em todos os momentos. Aos professores Stefano Rosatti e Gauti Kristmannsson, da Universidade da Islândia, por acolherem minha pesquisa por lá, e à Prof. ${ }^{a}$ Silvia Zoppi Garampi pela rica conversa e pelo amor ungarettiano compartilhado.

Aos meus colegas e amigos Marcelo de Souza Moreira e Telma Franco, ao Grupo de Estudos e Pesquisas em Literatura Italiana e Tradução, em especial às colegas Dayana Loverro, Leila Marangon e Laura Fiore Ferreira. 
À Casa das Rosas e à Casa Guilherme de Almeida, por tantos anos de parceria e amizade, ao seu diretor Marcelo Tápia, a todos os meus alunos que por lá passaram. Ao Instituto Italiano de Cultura, em especial a Sara e João.

Aos que fizeram dos meus longos anos em São Paulo e no mundo motivo de júbilo: Francesco D’Amico, Diya Ghosh, Paula Villanueva, Ligiana Costa, Eunice Souza Costa, William Zeytounlian, Isabella Martino, Roberta Ferraz, Ana Rüsche, Lubi Prates, Simone Paulino, Donny Correia, Simone Homem de Mello, Dirceu Villa, Maria Helena Serrano, Fabianne Secches, Fred Spada, Vanderley Mendonça, Maria Borio, Franca Mancinelli, Alex Dias, Fernanda e Daniela Almeida Prado, Prof. Antônio Lázaro de Almeida Prado e tantos outros.

Às minhas mães-de-luz, Paula, Ana Rita e Myrthes, a quem dedico este trabalho. Por todo o apoio amoroso e incondicional, sempre, mesmo sem entenderem a fundo este meu caminho, por serem matéria viva de inspiração e luta. Ao Paolo, meu pai, por ter me mostrado a poesia nas andanças e silêncios. À minha avó Sônia e à minha tia Antonella. Aos meus avôs Gino e Alceu, in memoriam. Ao meu querido analista Alexandre, por ter caminhado comigo por outros arquivos.

Ao Luciano, por ter me mostrado a importância da vida além dos arquivos e das cartas de amor, por ter me ensinado o risco que se deve correr para observar horizontes mais amplos, sentir o cheiro do Atlântico norte e inscrever no hoje o que ainda é porvir.

É UMA LONGA ESTRADA REPATRIAR A ALMA

Há que se faz̧er o silêncio

para owvir os dedos

sobre o velho piano da ferrovia

é uma longa estrada repatriar a lama

a rota é na medula

descida ingreme

ou subida sem estanque -

demolir para construir

e não fugir do terror sem nome

de não ser contido

apanhado, compreendido

é preciso seguir adiante

no fogo e sem ar

e se a dor perdurar

é preciso ser destemido

para espelhar o rosto

em outros olhos

distantes como num espelho.

Ribeirão Preto, maio de 2019

Francesca Cricelli 

$[\ldots]$

Tolo quem vê termo às loucuras do amor,

Pois o sol cavalgará cavalos negros,

a terra dará trigo de cevada,

O fluxo pulará dentro da fonte

Antes que amor se saiba moderar,

E o peixe nadará em riachos secos.

Não, enquanto dure, que o fruto da vida seja incessante.

Poema de Ezra Pound extraído de uma elegia de Propércio vertida ao português por Dirceu Villa

Sustento ao infinito, para o ausente, o discurso de sua ausência.

Roland Barthes, Fragmentos de um discurso amoroso 



\section{ÍNDICE}

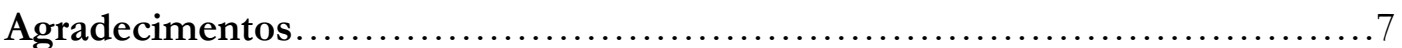

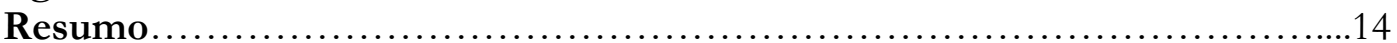

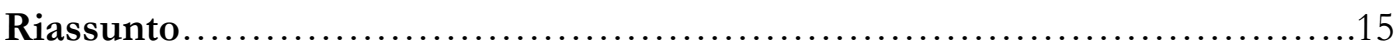

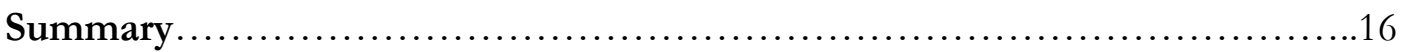

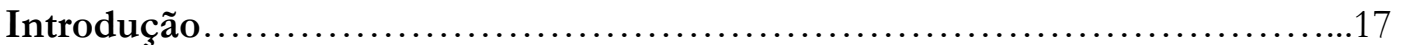

1 A DESCOBERTA DE UM ARQUIVO EPISTOLAR

1.1 A DESCOBERTA DE UM ARQUIVO EPISTOLAR ......................23

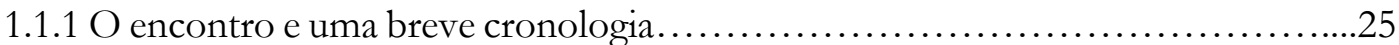

1.2 ALGUMAS CONSIDERAÇÕES SOBRE O GÊNERO EPISTOLAR ...........28

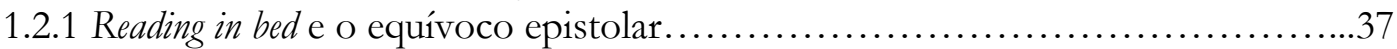

1.2.2 Retorno ao biográfico ou autobiográfico?..................................42

2 ESTRUTURA DO ARQUIVO E RECORTE

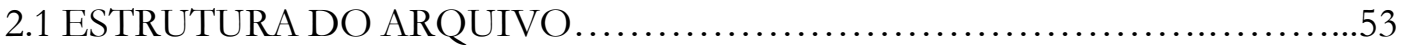

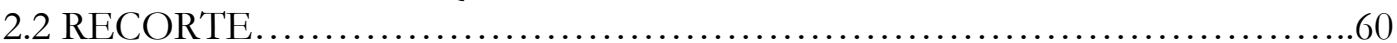

\section{O PORTO SEPULTO DA POÉTICA TRADUTÓRIA DE UNGARETTI}

3.1 UNGARET'TI TRADUTOR ..........................................71

1.1.1 A PRESENÇA E O PAPEL DA TRADUÇÃO NAS CARTAS A BRUNA......78

4 UMA LEITURA POSSÍVEL

4.1 UMA LEITURA POSSÍVEL.............................................99

4.2 PERLABORAÇÃO DO POEMA E QUESTÕES DE CRÍTICA LITERÁRIA...100

4.2.1 A língua e a confusão entre línguas..................................... 103

4.2.2 Traduções e tradutores................................................. 108

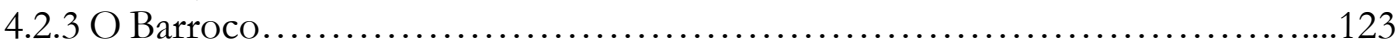

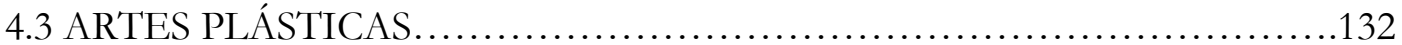

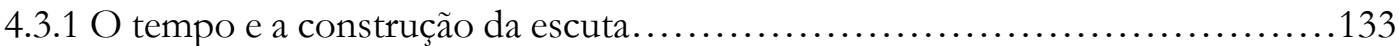

4.3.2 O caráter europeu da obra e das relações de Ungaretti.........................135

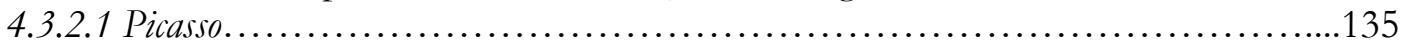

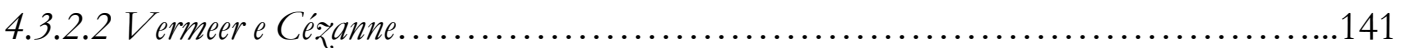

4.3.2.3 Fautrier, De Chirico, Savinio, Modigliani, Burri, Dorazio e Cagli......................145

4.4 ARTES, ARTISTAS E INTELECTUAIS NO BRASIL DE UNGÀ.............168

TRADUÇÃO COMENTADA DAS CARTAS

PRIMEIRA PARTE...................................................... 189

SEGUNDA PARTE ...................................................... 427

TERCEIRA, QUARTA E QUINTA PARTES................................453

5 CONSIDERAÇÕES FINAIS........................................... 475

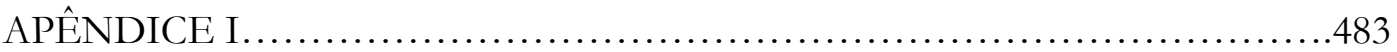

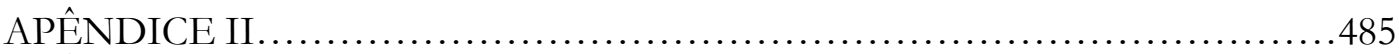

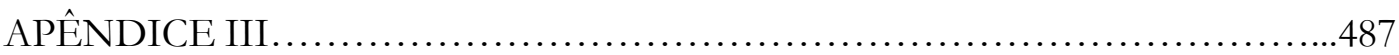

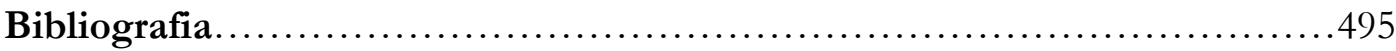




\section{RESUMO}

Diálogos em tradução - Cartas a Bruna de Giuseppe Ungaretti apresenta em primeira mão um estudo sobre o epistolário de Giuseppe Ungaretti para a sua musa ítalo-brasileira. Após cinquenta anos do início desta relação epistolar, recebemos a autorização de Bruna Bianco para transcrever, organizar, traduzir e estudar as cartas enviadas pelo poeta à sua amada. Esta tese tem como preocupação primária indagar qual o papel do pesquisador-tradutor diante da descoberta de um arquivo inédito e de grande importância para os estudos literários, especialmente no campo da italianística. Para oferecer alguma resposta a essa pergunta, percorremos um caminho através da apresentação da descoberta do arquivo, da análise de sua estrutura e recorte apresentado, observando o trabalho desenvolvido por Ungaretti, anteriormente, como tradutor, e a presença das traduções como recriações nas missivas a Bruna. Por fim, apresentamos uma cartografia para navegação no arquivo, uma leitura possível, um recorte da transcrição das cartas e nossa tradução anotada.

Palavras-chave: tradução, Ungaretti, poesia, cartas, Bruna Bianco, poesia italiana 


\section{RIASSUNTO}

Dialoghi in tradurione - Lettere a Bruna di Giuseppe Ungaretti presenta di prima mano uno ricerca sull'epistolario di Giuseppe Ungaretti alla sua musa italo-brasiliana. Dopo cinquanta anni dall'inizio del loro rapporto epistolare abbiamo ricevuto l'autorizzazione di Bruna Bianco per trascrivere, organizzare, tradurre e studiare le lettere inviate dal poeta alla sua amata. Questa tesi ha come scopo primario riflettere su quale sarebbe il ruolo del ricercatore-traduttore che dinnanzi a una scoperta simile di un archivio inedito e di grande importanza per gli studi letterari. Per offrire alcune risposte a questa domanda abbiamo percorso un cammino di presentazione della scoperta dell'archivio, analisi della struttura e del ritaglio presentato, osservando il lavoro sviluppato da Ungaretti, precedentemente, come traduttore e la presenza delle traduzioni come nuove creazioni nelle lettere dedicate a Bruna. Infine, presentiamo una cartografia per la navigazione dell'archivio, una lettura possibile, un ritaglio della trascrizione effettuata delle lettere e la nostra traduzione con note.

Palavre-chiavi: traduzione, Ungaretti, poesia, lettere, Bruna Bianco, poesia italiana 


\section{SUMMARY}

Dialogues in translation - Letters do Bruna by Giuseppe Ungaretti presents a first-hand study of the letter archive of Giuseppe Ungaretti to his Italian-Brazilian muse. After fifty years of the start of their relationship, we were authorized by Bianco to transcribe, organise, translate, and study the letters sent by the poet to his beloved. This thesis has a primary concern the scope of indagating the role of the researcher-translator as she discovers an unpublished archive of great relevance for Literary Studies, particularly in the field of Italian Studies. To offer an answer to this question, we have followed a path presenting the archive, analysing its structure and presented edition, observing both the work previously done by Ungaretti as a translator and analysing the presence of translations as recreations in the letters to Bruna. Finally, we present a possible cartography for navigating the archive, proposing how it could be read, as well as presenting an edition of the transcribed letters and our annotated translation.

Keywords: translation, Ungaretti, poetry, letters, Bruna Bianco, Italian poetry 


\section{INTRODUÇÃO}

Diálogos em tradução: Cartas a Bruna de Giuseppe Ungaretti apresenta em primeira mão um estudo sobre o epistolário de Giuseppe Ungaretti para sua musa ítalo-brasileira. Após cinquenta anos do início desta relação epistolar, recebemos a autorização de Bruna Bianco para transcrever, organizar e estudar as cartas enviadas pelo poeta à sua amada. O corpus total é de 375 cartas e 2 telegramas escritos entre 14/09/1966 a 14/04/1969. Este corpus é a base do livro Lettere a Bruna editado pela Mondadori em 2017 com prefácio de Silvio Ramat. Nosso trabalho de transcrição e organização é anterior à publicação. Nesta tese, apresentamos um recorte traduzido e comentado deste arquivo.

Esta tese tem como preocupação primária indagar qual o papel do pesquisador-tradutor diante da descoberta de um arquivo inédito e de grande importância para os estudos literários, especialmente no campo da italianística. Para oferecer uma resposta a essa, pergunta percorremos um determinado trajeto. No primeiro capítulo, situamos o leitor em relação à história da descoberta do arquivo, oferecemos uma breve cronologia dos anos que levaram ao encontro de Giuseppe Ungaretti com Bruna Bianco e como se deslocaram nos anos de correspondência. Em seguida, apresentamos algumas considerações sobre o gênero epistolar, apresentando algumas das discussões mais pertinentes sobre o seu vínculo com os estudos literários, e então propomos observar o nosso objeto de estudo como uma obra que se encaixaria nos termos denominados por Philippe Lejeune como "espaço autobiográfico". É importante, de toda forma, frisarmos como estas missivas habitam o espaço literário não somente como fonte de informação sobre a vida e os processos de criação do autor, mas com o peso de um retorno ao autobiográfico que acompanha o interesse de estudos e publicações na contemporaneidade. Neste sentido, apontamos o que pode ser lido, nestas cartas, como uma dose de autoficção. Nos amparamos nas leituras do já citado Philippe Lejeune, mas também de Vincent Kaufmann, Brigitte Diaz e André Lefevere (em particular a visão deste último sobre tradução, reescrita e manipulação da fama literária). No segundo capítulo, nos ocupamos do trabalho formal de fixar um texto do manuscrito para sua transcrição. Além de apresentarmos descrições físicas das cartas — incluindo algumas fotos no corpo do texto e também no Apêndice III — discutimos a estrutura do arquivo e o nosso recorte, amparados por leituras de Alan Páges, Brigitte Diaz 
e Walnice Nogueira Galvão. No terceiro capítulo, já enfrentada a questão do recorte, apresentamos com maior atenção Ungaretti enquanto tradutor nestas cartas endereçadas a Bruna. Após um breve excursus com relação ao seu histórico como tradutor de poesia, analisamos de que forma o autor lança mão de poemas de James Joyce, al-Mutanabbi e Ibrahim Ibn Sahl e, num gesto de transcriação mefistofélica, para dizê-lo com Haroldo de Campos, extrai seus próprios poemas para a amada. Amparamo-nos aqui na leitura, entre outros, do próprio Haroldo de Campos mas também no posfácio de Marcelo Tápia ao volume de seus ensaios reunidos Transcriação. ${ }^{1}$ Enfim, no quarto e último capítulo, apresentamos o que observamos como uma resposta parcial à indagação inicial: qual o papel do pesquisador-tradutor diante da descoberta de um arquivo inédito? Uma das respostas é propor ao leitor deste arquivo um percurso, uma cartografia, para navegar o extenso arquivo, mesmo em seu recorte. Nossa proposta de leitura incide sobre os seguintes temas contidos no recorte privilegiado: a perlaboração do texto poético e questões de crítica literária, a relação de Ungaretti com a tradução e com seus tradutores, o que emerge nas cartas sobre o Barroco, seu vínculo fértil com as artes plásticas através dos discursos proferidos em carta e outras publicações, deste mesmo recorte histórico, sobre Picasso, Vermeer, Cézanne, De Chirico, Modigliani e outros artistas com quem o poeta colaborou, como Burri, Cagli e Dorazio. Enfim, dedicamos atenção especial às relações e aos vínculos de Ungaretti com as artes e com artistas e intelectuais brasileiros. No final da nossa proposta de leitura, nossa cartografia para navregação, apresentamos as cartas — tal como foram transcritas (no período entre 2013 e 2015), acompanhadas de nossa tradução anotada.

Enfim, em nossas considerações finais, tentamos pensar mais uma vez o papel do pesquisador diante da descoberta do arquivo epistolar, a tradução como meio de leitura profunda, a organização e a crítica na contemporaneidade — mas também na própria escrita de epístolas, gesto que se perde no agora, como busca de uma narrativa de si e de uma escuta privilegiada do outro, seu leitor.

${ }^{1}$ CAMPOS, Haroldo. Transcriação. Org. Marcelo Tápia e Thelma Médici Nóbrega. São Paulo: Perspectiva, 2015. 

A DESCOBERTA DE UM ARQUIVO EPISTOLAR

1.1 A DESCOBERTA DE UM ARQUIVO EPISTOLAR

1.1.1 O encontro e uma breve cronologia

1.2 ALGUMAS CONSIDERAÇÕES SOBRE O GÊNERO EPISTOLAR

1.2.1 Reading in bed e o equívoco epistolar

1.2.2 Retorno ao biográfico ou autobiográfico? 



\subsection{A DESCOBERTA DE UM ARQUIVO EPISTOLAR}

No final do ano de 2011, fui convidada para trabalhar na curadoria de uma exposição na Casa das Rosas, cuja abertura seria no ano seguinte, por volta de junho de 2012, com o objetivo de integrar os festejos do primeiro sesquicentenário da unificação italiana. Pareceu-me natural ocupar-me, sobretudo, de Giuseppe Ungaretti, para forjar este elo entre a Itália e o Brasil. Para além do recorte que fiz dentro da biblioteca de Haroldo de Campos, expondo o que em seu acervo havia de literatura italiana e trazendo à tona os processos de tradução dos cantos da Comédia, das rimas pedrosas e dos poemas de Ungaretti dentro das anotações do poeta recriador, quis montar um cômodo da casa inteiramente dedicado ao poeta nascido em Alexandria, resgatando, desta forma, alguma memória de sua permanência no Brasil, os vínculos aqui estabelecidos e as sementes plantadas que seriam mais tarde os frutos colhidos a partir da década de 1960. Serviu-me de inspiração para a exposição e ciclo de encontros entre escritores e críticos italianos e brasileiros o título do volume de traduções organizado por Lucia Wataghin, daquela estrela à outra, ${ }^{2}$ pois decidimos denominar nossa exposição de uma estrela a outra, tentando traçar através desse nome um caminho de correspondências. Este breve preâmbulo serve como reconstrução do cenário de fundo em que ocorreu meu primeiro contato com Bruna Bianco e com as cartas que Giuseppe Ungaretti lhe dedicou entre os anos de 1966 e 1969.

Ainda que seja uma fugaz anedota, sem valor científico, devo relembrar o exato momento em que soube que poderia ter algum contato direto com Bruna Bianco. Numa tarde de agosto, recebo um bilhete da recepcionista da Casa das Rosas com o nome Bruna Bianco e um número de celular. Segundo a recepcionista, eu estava em reunião e, por esse motivo, não me chamara para conhecer pessoalmente a senhora que desejava saber quem estava por trás da curadoria da exposição. Recebi o recado com um tanto de espanto, já que nenhuma reunião poderia ser mais importante do que conhecer a mulher com quem Giuseppe Ungaretti não só se correspondera por vários anos, mas com quem também publicara um pequeno livro de líricas intitulado Dialogo no ano de 1968. Havia um adjetivo num poema de Bruna, incluído naquele volume, que me chamara a atenção anos antes: ela descrevia São Paulo como drusiaca città e esta imagem, esta dúvida sobre o que realmente significava esse adjetivo, me acompanhava há um bom tempo. Olhando aquele bilhete, por

\footnotetext{
2 UNGARETTI, Giuseppe. Daquela estrela à outra. Organização de Lucia Wataghin, tradução de Haroldo de Campos e Aurora Fornoni Bernardini. São Paulo: Ateliê Editorial, 2003. Cabe também um agradecimento especial à professora Lucia Wataghin por ter fornecido todo o material em vídeo da exposição, cedido a ela por uma jornalista da Rai, assim como os manuscritos da tradução de Haroldo de Campos que foram expostos na Casa das Rosas.
} 
fim, eu imaginava que poderia, no mínimo, perguntar-lhe algo sobre aquele verso. A verdade é que a curiosidade de olhar nos olhos o último grande amor de um dos maiores poetas do século XX e de saber dos bastidores de um dialogo poético eternizado numa publicação de pequena tiragem me lançavam impetuosamente ao encontro de Bruna. Após um primeiro contato no qual Bruna me entrevistou, pedindo o meu currículo e um compêndio dos meus próprios poemas, pude ler algumas cartas de Giuseppe Ungaretti transcritas à máquina por alguém que, nos anos de 1990, havia auxiliado num início de transcrição das missivas. A partir desse primeiro encontro, quando eu ainda não mantinha vínculo algum com a universidade ou com a pesquisa, propus a Bruna minha assistência em caráter gratuito para organizar o seu acervo e transcrever todas as cartas que ela havia recebido do poeta entre 1966 e 1969. Há dois únicos registros de publicação prévia parcial destas cartas: uma é a tradução de Lucia Wataghin ${ }^{3}$ publicada no jornal Folha de São Paulo, acompanhando a entrevista de Bruna Bianco cedida a Augusto Massi; a outra, um apresentação de três cartas publicadas em maio de 1999 na revista Quaderni ${ }^{4}$ do Instituto Italiano de Cultura, apresentadas por Anna Carboncini, do Instituto Lina Bo e P.M. Bardi, e amiga pessoal de Bruna Bianco. As cartas apresentadas naquela seleção são: a primeira e mais longa, enviada por Ungaretti em setembro de 1966, ainda durante a viagem de retorno à Itália; uma outra datada de 31 de outubro de 1966 e enviada de Roma; e, por fim, uma datada de 15 de novembro de 1966, escrita em Paris durante uma série de reuniões a que o poeta compareceu na sede da Unesco naquela cidade. As primeiras que Bruna havia recebido de Ungaretti foram transcritas nos anos de 1990 por incentivo de Pietro Bardi. Naqueles anos, Bianco se encontrara no MASP com uma voluntária, esposa de um executivo da Pirelli, para transcrever as missivas. Por motivos que desconhecemos, a relação não perdurou por muito tempo, e pouco mais do que dez cartas foram transcritas.

O trabalho de transcrição das cartas foi feito junto a Bruna Bianco, com quem examinei cada carta manuscrita durante os anos de 2013 a 2015. Foram dois anos de trabalho assíduo, durante o qual nos encontrávamos todas as sextas em seu domicílio; um cômodo especial da casa, situada na rua Abegoaria, foi dedicado a esse trabalho: lá estavam a biblioteca com todas as obras de Ungaretti, os quadros de Cagli e de outros artistas que retrataram o poeta, as bengalas de Ungaretti — as quais ele passou a não usar mais a partir do seu encontro com Bruna, e outros objetos que o poeta enviara à sua maior interlocutora

\footnotetext{
${ }^{3}$ WATAGHIN, Lucia. "Te amo muito, de maneira desmedida". In Folha de São Paulo. Domingo, 21 de julho de 1996. Caderno “+mais!” https://www1.folha.uol.com.br/fsp/1996/7/21/mais!/8.html.

${ }^{4}$ CARBONCINI, Anna. Il carteggio Ungaretti-Bruna Bianco. In Quaderni. Nuova serie, n. 8, maggio 1999, Istituto Italiano di Cultura, São Paulo.
} 
nos últimos anos de sua vida. Foram transcritas trezentas e oitenta e seis cartas e dois telegramas enviados por Ungaretti entre os anos de 1966 e 1969. Não tive acesso às cartas que Bruna enviou ao poeta, as quais foram resgatadas em 2015 após contato com Anna Lafragola, a neta de Ungaretti, que atualmente é a detentora dos direitos autorais do avô. Bruna me revelou que tem trabalhado sozinha na transcrição dessas cartas. Salvo em dado momento em que pude ler trechos de algumas cartas, em suas mãos - mas sem transcrevê-las nem fazer qualquer anotação - não tive de resto acesso a esse material. Bruna, nesse momento, não deseja que essas cartas sejam lidas. Meu maior interesse no conteúdo delas é justamente ler as versões originais dos poemas que Bruna escreveu e que estão contidos no volume Dialogo. Através das respostas de Ungaretti, pude ler as sugestões de mudanças nos versos, comparar a evolução dos poemas numa troca cotidiana de cartas, mas não pude ler a primeira versão dos poemas. Quiçá este material se torne disponível para o público no futuro; caso isso ocorra, seria interessante observar o trabalho de edição exercido pelo poeta.

\subsubsection{O encontro e uma breve cronologia}

O encontro de Bruna e Ungaretti acontece graças a outra breve correspondência, muito importante, que o traz de volta ao Brasil nos anos de 1960. A troca de cartas é com Edoardo Bizzarri, tradutor de Guimarães Rosa e então diretor do Instituto Italiano de Cultura em São Paulo. ${ }^{5}$ Aquelas cartas, mesmo tratando-se de uma troca formal e burocrática, trazem à tona o respeito e o afeto existente entre aqueles dois homens de cultura. Percebese, naquelas cartas, o ávido desejo do poeta de voltar ao Brasil, e também a dificuldade da organização de tal viagem, além das dificuldades da comunicação em si, com os extravios de telegramas. Desde que voltara à Itália, em meio à Segunda Guerra, Ungaretti só havia visitado o Brasil em 1954, quando proferiu algumas palestras e fez uma leitura de suas traduções de poemas de Mário de Andrade no edifício da Universidade de São Paulo na Rua Maria Antônia. Foi uma breve passagem, esse seu retorno à "terra da trágica agonia": teve pouco tempo para rever os amigos e pisar o solo do país que lhe extirpara a pessoa mais amada — o filho Antonietto, falecido com somente nove anos devido a uma apendicite mal curada - como ele mesmo escrevera a Bizzarri numa carta datada de 3 de julho de 1966, motivando a razão da sua visita: “[...] volto para rever um país amado, o mais

\footnotetext{
${ }_{5}$ A breve correspondência foi organizada e traduzida por nós no volume: BIZZARRI, Edoardo. UNGARETTI, Giuseppe. Cartas Lettere 1966/67. São Paulo: Scriptorium/Instituto Italiano de Cultura, 2013.
} 
amado de todos que preserva o corpo e os últimos gritos de quem mais amei na Terra". Foi aqui, entre 1939 e 1940, que Ungaretti escrevera a primeira versão do poema "Gridasti soffoco", no qual teceu em versos o horror daquela sua grande perda. ${ }^{6}$

Em meio à correspondência de Ungaretti e Bizzarri, parte de um acervo encontrado por acaso pelo arquivista João Carlos Destro no Instituto Italiano de Cultura, há um cartão postal assinado pelo poeta e por Antonio Candido, quando ambos se encontravam em Gênova, no qual cumprimentavam Bizzarri pela sua tradução de Corpo de Baile, de Guimarães Rosa, publicada na Itália em 1964. Pequenos detalhes como esse demonstram como Ungaretti permanecera sempre próximo do Brasil, ao menos em seu imaginário, e que vinha cultivando há algum tempo aquele desejo de retorno. O encontro de Bruna e Ungaretti acontece durante esta primeira parte da viagem de retorno do poeta, no mês de agosto de 1966. A respeito deste primeiro encontro, possuímos um depoimento de Bruna Bianco, ${ }^{7}$ que foi parcialmente reproduzido no volume que organizamos das cartas de Ungaretti e Bizzarri. ${ }^{8}$ O poeta contava então setenta e oito anos; Bruna, vinte e seis. Ela o procurara no hotel Ca' d'Oro para mostrar-lhe alguns poemas seus. Nos dias após o primeiro encontro, passarão um período juntos em São Paulo. O verdadeiro encontro que acontece é o entendimento que se instaura entre os dois, a admiração mútua, o carinho e a troca literária e poética que alimenta por três anos uma densa rede de cartas, traduções, livros e relatos de viagem. Num depoimento sobre este primeiro encontro, Bruna relata:

\footnotetext{
Stavo leggendo il giornale di mia abitudine "O ESTADO DE S. PAULO" e incontrai nel quaderno, dedicato alla letteratura, la foto di Ungaretti, con la notizia della sua visitazione alla città di S. Paulo. Il suo volto era aperto con un sorriso felice, bensí le spalle un pó curve al peso della saggezza. Da quell'istante fui posseduta d'una impazienza irrazionale, legando il mio pensiero al poeta per tutta la giornata. ${ }^{9}$
}

As primeiras cartas enviadas pelo poeta a Bruna Bianco vão justamente desse período após e encontro em agosto de 1966 até a volta de Ungaretti ao Brasil em abril de 1967. Durante esta segunda viagem, Ungaretti permanece no país até junho de 1967. Em São Paulo, mantém contato sobretudo com Paulo Emílio Sales Gomes, Ciccillo Matarazzo e a família Magnelli. Através de Alcântara Machado, e a convite dos governadores de Minas Gerais e da Bahia, Ungaretti visita Belo Horizonte, as cidades históricas de Minas Gerais e Salvador, sempre acompanhado de Bruna. Seu intuito era conhecer melhor as expressões mais importantes do Barroco brasileiro. Em Salvador, Bruna e Ungà visitam Jorge Amado e

\footnotetext{
${ }^{6}$ Ibid., p. 17.

7 Vide Apêndice I.

8 BIZZARRI, Edoardo. UNGARETTI, Giuseppe. Op. cit., p. 95-101.

${ }^{9}$ Vide Apêndice I.
} 
família, Caribé, Mário Cravo, Emmanoel Araújo e Joaquim Floriano. Em novembro do mesmo ano, Ungaretti volta ao Brasil, recebendo em São Paulo, nessa ocasião, o título de doutor honoris causa pela Universidade de São Paulo. Durante esta estada, viaja com a Bruna também a Buenos Aires a convite da Olivetti, participando do júri de um prêmio literário. Durante aquela mesma viagem, visita a mãe e a irmã de Jorge Luis Borges que, segundo Bruna, encontrava-se em exílio. De Buenos Aires, viajaram para Bariloche por alguns dias, e de lá para o Peru, onde Ungaretti recebeu outro título honoris causa pela Universidade $\mathrm{Na-}$ cional Maior de São Marcos, em Lima. Bruna e Ungà visitam Cusco e Machu Picchu. Pouco tempo depois, em janeiro de 1968, Bruna vai para a Itália e lá permanece até o final de março. Em fevereiro, ela e Ungà passam um período em Capri, onde Ungaretti traduz uma parte da Odisseia, diretamente do grego, para um programa da Rai. Passados esses dias, viajam a Carso, onde visitam o cemitério dos heróis de guerra. Em março, se hospedam com a família de Bruna em Canelli, no Piemonte. Em Alba, encontram Cagli, Dorazio e Nini Santoro. ${ }^{10}$ Em 1968, celebra-se o aniversário de oitenta anos do poeta, e Bruna voltará mais uma vez à Itália no mês de setembro. Nessa ocasião, é apresentado o volume Dialogo, com as poesias de Ungaretti e Bruna. São publicadas cinquenta e nove cópias não comercializadas, com uma combustão de Burri, em edição da Fògola na cidade de Turim. A ideia do livro nasce já em outubro de 1966. Ungaretti havia inicialmente pensando em publicar de forma anônima os poemas e intitular o volume Il libro di un Amore Segreto. ${ }^{11}$ Em 1969, Bruna volta à Itália e acompanha o poeta em sua viagem a Munique. Visitam então Hamburgo e passam algumas semanas em São Galo, na Suíça, onde encontram Dorazio e os donos da Galeria Erker para conversarem sobre a preparação do livro La Luce. Sempre acompanhado por Bruna, Ungaretti viaja até Crotone para receber um prêmio e, de lá, vão até Taormina, onde são recebidos por Cagli. Nos dias que passam juntos em Roma, Ungaretti apresenta Bruna aos artistas e intelectuais que frequentava naqueles anos, entre eles Burri, Pasolini, Angelini, Manzù e Elsa Morante. Voltam à região de Alba para a

\footnotetext{
${ }^{10}$ Corrado Cagli (1910-1976), artista plástico, cujo catálogo da exposição nos anos da correspondência com Bruna contou com um texto escrito por Ungaretti. Piero Dorazio (1927-2005), artista plástico, ilustra o volume La Luce, contendo poemas de Ungaretti do período 1914-1961. Pasquale Nini Santoro (1933-), artista plástico italiano que trabalhou com escultura, pintura, gravuras, amigo de Giuseppe Ungaretti, sobre o qual o poeta testemunhou no volume Racconto: “So per istinto, per vocazione e per lunga pratica d'un'arte, distinguere senza ingannarmi mai, distinguere, intendo dire, da un artista un ciarlatano, e da quel lontano giorno del 1958, quel guardare e quasi senza farci attenzione, alcune acqueforti di Santoro, mi sono persuaso che Santoro è un artista, un artista nato, un artista che va di attimo in attimo, progredendo, cocciuto e illuminato, stravagante e osservante stretto della regola, cercandosi la propria strada, un artista che finalmente, credo, abbia trovato la strada che gli darà quelle maggiori soddisfazioni alle quali un artista vero possa ambire. Quel non molto lontano giorno del 1958, anche se avevo solo settant'anni, e non ancora la perizia che distingue i giovincelli di ottant'anni, seppi subito che Santoro meritava ciò che mi chiedeva, ossia d'essere presentato a Jean Paulhan, a quell'occhio e a quella mente sicuri che da Braque a Fautrier, agli attuali giovanissimi più dotati, ha incitato e giustificato tutte le iniziative fertili, e quindi necessariamente rivoluzionarie dell'arte d'oggi." Giuseppe Ungaretti, 1968. In SANTORO, Pasquale Nini. Racconto, Roma: Exorma Edizioni, 2014.

${ }_{11}$ Carta datada de Roma, 27 de outubro de 1966.
} 
inauguração do monumento à Resistência de Santoro. Segundo Bruna, naquela época, Ungaretti demonstra já os primeiros sintomas de um mal-estar respiratório. No começo de 1969, Ungaretti pede a Bruna que venha a seu encontro nos EUA, onde ele ministrava algumas aulas na Universidade Columbia e depois em Harvard. Porém, nesse mesmo período, Bruna sofre um acidente grave em seu local de trabalho — um incêndio no depósito da empresa familiar — o que a impede de encontrar Ungà em Nova Iorque. O poeta, que prometera estar no Brasil para o aniversário de Bruna, não consegue se desvencilhar dos compromissos assumidos nos EUA. Nunca mais se encontrariam pessoalmente. Com o tempo, a partir desta data, diminuíram as cartas que Bruna recebia de Ungaretti. O poeta acusava, em algumas comunicações, não mais receber nenhuma carta de Bruna. Em depoimento pessoal, durante o período de transcrição das missivas, ela insistiu que continuou a lhe escrever. Alguns meses antes da morte do poeta, ele envia um livro de arte com poemas seus para Bruna, escrevendo em sua dedicatória: "meu amor por ti arde/ sempre sob as cinzas". ${ }^{12}$

\subsection{ALGUMAS CONSIDERAÇÕES SOBRE O GÊNERO EPISTOLAR}

Nos tempos da Antiguidade grega e romana, a carta (Ars Dictandi $)^{13}$ era vista como um meio de se usar e treinar a persuasão, o argumento e o convencimento, isto é, a arte retórica, quaisquer que fossem os assuntos e temas. Temos, certamente, nas cartas de Horácio, Sêneca e Cícero, um panorama amplo do desenvolvimento da arte epistolar, mas também nas cartas de São Paulo, que são uma referência para toda a cultura cristã ocidental, não somente como mediação entre o divino e o terreno, mas também como exemplo de uma forma epistolar que combina também a oratória. Há, nas cartas, um discurso que deve trazer um arranjo adequado de palavras, mas sem se distanciar do caráter presente num diálogo. Ao longo dos anos, a correspondência passou por várias e significantes transformações, mudando desde as suas características até a sua função e o seu modo de se proceder. Há uma passagem histórica da Antiguidade à Idade Média em que floresce a exigência de submeter a técnica do discurso, oral e epistolar, a uma codificação precisa e sistemática

\footnotetext{
12 O relato da dedicatória pode ser lido aqui: "L'amore mio per te arde/ sempre sotto la cenere. Ungà". GRASSO, Sebastiano. Ungaretti e Bruna Bianco: M'illumino d'amore. Pen Club Italia, setembro de 2013 (http://www.penclub.it/c/125137/18243/ungaretti-e-bruna-bianco.html, consultado em 16 de outubro de 2016). ${ }^{13} \mathrm{Da}$ Ars dictaminis há, como definição de carta, aquela encontrada no tratado Rationes dictandi, de 1135, de um autor anônimo da cidade de Bolonha. Segundo esse tratado, a carta "é adequado arranjo das palavras assim colocadas para expressar o sentido pretendido por seu remetente. Ou, noutras palavras, uma carta é um discurso composto de partes ao mesmo tempo distintas e coerentes, significando plenamente os sentimentos de seu remetente." In TIN, Emerson (org.) A arte de escrever cartas. Campinas: Editora da Unicamp, 2005.
} 
(ars dictandi ou dictaminis). Esta se difunde no século XII, paralelamente à expansão dos centros urbanos e ao consequente desenvolvimento das atividades públicas e administrativas. Não por acaso, a maior parte dos exemplos vem de Bolonha, cidade em que a ars dictandi nasce conectada às atividades de chancelaria e tabelionato.

Se pensarmos, novamente, a carta como um arranjo adequado de palavras, que, porém, não se distancie do caráter coloquial presente num diálogo, podemos recordar Erasmo de Roterdã em sua Brevíssima e muito resumida fórmula de elaboração epistolar, ${ }^{14}$ publicada em 1520, em duas colocações: uma, concernente ao "estilo epistolar", que "deve ser simples e mesmo bastante descuidado, no sentido de um descuido estudado"; ${ }^{15}$ a outra, concernente à sua definição do tipo de comunicação que é possível existir na correspondência: Erasmo diz que o sofista grego Libânio define a carta como um "colóquio de ausente a ausente". ${ }^{16}$ Talvez seja essa definição a que mais nos sirva ao observarmos o nosso objeto de pesquisa. Há, sobretudo na epistolografia amorosa, uma troca entre ausências em que cada carta enviada urge representar algo que não pode ser suprido, ou seja, não só a ausência do outro - mas sua própria falta e incompletude, forjando, nessas condições, através das palavras, aquilo que Philippe Lejeune denomina como "espaço autobiográfico". ${ }^{17}$ Digamos que as cartas não se encaixem nem dentro daquilo que o autor descreve como pacto autobiográfico tampouco no que seria o pacto romanesco. Nesse caso, talvez possamos tentar alguma aproximação como o dito espaço autobiográfico, ou mesmo aquilo que Lejeune denomina pacto fantasmático. ${ }^{18}$ Extrapolando algo de sua definição, diríamos que o leitor “[...] é assim convidado a ler os romances não apenas como ficções remetendo a uma verdade da 'natureza humana', mas também como fantasmas reveladores de um indivíduo". ${ }^{19}$ De certa forma, a extensa correspondência entre Giuseppe Ungaretti e Bruna Bianco poderia ser — quase numa provocação fronteiriça entre gêneros — um romance epistolar autobiográfico, ou, sendo ainda mais ousados: autoficcional. Isso é o que Lejeune chama de pacto autobiográfico sob forma indireta, e é essa mudança de ângulo que nos

\footnotetext{
${ }^{14}$ Ibid.

${ }^{15}$ Ibid., op. cit., p. 112.

16 Ibid., op. cit., p. 83.

${ }^{17}$ Há uma discussão muito mais ampla levantada pela pesquisa de Lejeune, mas nosso objetivo por agora é beber de algumas questões por ele apresentadas e adaptá-las ao estudo do nosso objeto. De forma sucinta, o que Lejeune coloca em discussão é o gênero autobiográfico: as relações entre biografia e autobiografia, as relações entre romance e autobiografia. Seu corpus de estudo, inicialmente, são textos publicados cujo tema comum é a contar a vida de alguém o período que cobre é de dois séculos (começa em 1770), e diz respeito à literatura europeia (LEJEUNE, Philippe. O pacto autobiográfico de Rousseau à Internet. Belo Horizonte: Editora da UFMG, 2008).

${ }^{18}$ Lejeune afirma haver um "pacto fantasmático", uma forma indireta de pacto autobiográfico que convida o leitor a ler esses romances não apenas como ficções, mas também como fantasmas que revelam um indivíduo. O acordo tácito com o leitor se dá com o distanciamento entre o autor, o narrador e o protagonista, por meio da diferença entre os respectivos nomes, bem como por meio de informações paratextuais que corroboram com o caráter ficcional da obra. ${ }^{19}$ Ibid., op. cit., p. 43.
} 
interessa para pensarmos as cartas e, com elas, os poemas e traduções produzidos nesse período e discutidos na relação epistolar. O pesquisador francês adverte:

\begin{abstract}
Não se trata mais de saber qual deles, a autobiografia ou o romance, seria o mais verdadeiro. Nem um nem outro: à autobiografia faltariam a complexidade, a ambiguidade etc.; ao romance, a exatidão. Seria então um e outro? Melhor: um em relação ao outro. O que é revelador é o espaço no qual se inscrevem as duas categorias de textos, que não pode ser reduzido a nenhuma delas. Esse efeito de relevo obtido por esse processo é a criação, para o leitor, de um "espaço autobiográfico". ${ }^{20}$
\end{abstract}

Claro que não estamos falando aqui nem de um romance nem de uma autobiografia, mas sim de um extenso epistolário que foi também oficina de criação de um livro de poemas, traduções, relatos de viagens e breves ensaios sobre arte e crítica. Neste sentido, por conter muitas manifestações literárias dentro de si, nosso objeto se aproxima da definição que Brigitte Diaz oferece sobre o gênero epistolar, ou seja, a carta como registro de um pensamento nômade:

As cartas são textos híbridos e rebeldes a quaisquer identificação genéricas. Gênero literãrio indefinível, flutuam entre categorias vagas: arquivos, documentos, testemunhos. De tal forma que não se sabe muito bem que lugar lhes é atribuído na geografia ordenada da literatura. A crítica do século XIX situou-as nas fronteiras do literário e as aprovou; gostou delas desde que não ultrapassem esse limite. ${ }^{21}$

Assim como e espaço autobiográfico citado por Lejeune é algo que abarca o biográfico mas também a ficção, o gênero epistolar, nos estudos de Brigitte Diaz, aponta à natureza paradoxal das cartas no âmbito literário. A questão é, justamente, como conter, dentro de um limite restrito, que não deveriam ultrapassar, as cartas. Ainda segundo Diaz, “[...] ao mesmo tempo que eram fervorosamente colecionadas, editadas, difundidas, comentadas, exatamente como obras de fato [...], foram reduzidas ao estatuto subalterno de dados biográficos ou psicológicos para servir à história de um homem e, eventualmente, de uma obra ${ }^{22}$. Há, segundo a autora, certa reabilitação do gênero e um retorno a ele, como se houvesse saído "discretamente do purtagório crítico no qual nossa modernidade o havia trancafiado ${ }^{23}$ " - mas o conflito provém do esgarçamento que, por um lado, observa as missivas como linhas demasiadamente próximas à vida, "miserável amontado de segredos", ${ }^{24}$ portanto depreciadas em seu valor intrínseco e literário; por outro, o pesquisador que se debruça longamente sobre este tipo de arquivo pode

\footnotetext{
${ }^{20}$ Ibid.

${ }^{21}$ DIAZ, Brigitte. Gênero epistolar. O pensamento nômade. São Paulo: Edusp, 2016, p. 11.

22 Ibid.

${ }^{23}$ Ibid., op. cit., p. 12.

${ }^{24}$ Ibid., op. cit., p. 13.
} 
ainda ser taxado de "fetichista [...] inocente ou perverso, dependendo das circunstâncias, fixa seu desejo nesses objetos", ${ }^{25}$ segundo Diaz, confeccionados pelos editores, mas o que dizer então quando o pesquisador é também quem revela o arquivo ao público? Talvez seja um ato ainda mais condenável, como veremos mais adiante, nas palavras de Sanavio sobre a publicação das cartas à Bruna.

As cartas à amada Bruna não são objetos isolados da obra poética, ensaística e tradutória de Giuseppe Ungaretti. Sendo assim, podemos adotar algo apontado por Lejeune como critério de leitura. ${ }^{26}$ Há uma dupla refração: a obra surge nas cartas — como se pudesse ser também a correspondência um laboratório de escrita e ideias - mas é também contaminada pelo diálogo cotidiano organizado em missivas; a obra é, por sua vez, fecundada pela troca de cartas. É neste sentido que tentamos apresentar nosso critério de leitura no capítulo 4, percebendo os pontos de tensão na escrita das cartas, os argumentos que ressurgem, os pontos nevrálgicos em que vida e obra se tocam, como se o critério de leitura partisse, também, do desejo de entender - através do íntimo diálogo — os caminhos explorados por Ungaretti ao tratar de grandes temas recorrentes em sua obra e pensamento: a tradução, a criação literária, o tensionamento da linguagem poética, a luz, a relação e o diálogo com as artes plásticas, as viagens e as redes de influência. Para recortarmos esta proposta, nos amparamos em Lejeune e Lefevere. Nos aproximamos a Lejeune no sentido de interpretar a correspondência de Ungaretti a Bruna dentro de um espaço biográfico de criação que é também literária; propomos um recorte de cartas sugerindo um pacto de leitura, colocando em evidência o espaço biográfico do poeta em diálogo com sua obra e com o trabalho que desenvolvia naqueles anos. Para Lejeune:

[...] a história da autobiografia seria então, antes de tudo, a história de seu modo de leitura: história comparativa na qual poderíamos fazer dialogar os contratos de leitura propostos pelos diferentes tipos de texto (pois nada adiantaria estudar a autobiografia isoladamente, já que, assim como os signos, os contratos só têm sentido por seus jogos de oposição), e os diferentes tipos de leitura a que esses textos são realmente submetidos. ${ }^{27}$

A criação atravessada pela vida e a vida atravessada pela obra, lendo, desta forma, o que pode existir tanto de biográfico quanto de ficção nas cartas. Pensamos, aqui, a ficção no sentido mais amplo do imaginário necessário para elaborar uma obra, mas também para elaborar o enredo de um diálogo amoroso. Lembramos, aqui, mais uma vez, Diaz, quando

\footnotetext{
25 Ibid.

${ }^{26}$ LEJEUNE, Philippe. O pacto autobiográfico de Rousseau à Internet. Belo Horizonte: Editora UFMG, 2008, p. 46. 
sugere que "[...] a relação epistolar convoca facilmente o modelo da paixão amorosa", 28 uma linha tênue na construção do outro, uma procura de algo que a autora descreve como “mesmice", citando Ricœur, ${ }^{29}$ onde a diferença é leve mas deve existir pois seria “[...] triste e estéril só conversar consigo mesmo, é preciso [...] um outro apoio, um segundo de si mesmo". ${ }^{30}$ Este segundo de si pode também soar como um duplo, um gêmeo, um self espelhado no passado ou no futuro, ainda segundo Diaz: “[...] o destinatário será esse outro si mesmo ou si mesmo como um outro: deliciosa duplicação que promete excitantes cara a cara" ${ }^{31}$ Se pensarmos, portanto, a correspondência como pertencente ao espaço biográfico, será fundamental observar sua função, ou seja, o gesto de endereçamento do discurso, como expõe Diaz: “[...] quaisquer que sejam os efeitos de verdade ou de ilusão que suscita, qualquer que seja a auntenticidade da ligação construída, a carta seria, portanto, antes de mais nada, endereçamento ao outro".32

Enfim, dentro do recorte de um pacto de leitura, dentro do espaço biográfico, cabe, ao abordar uma seleção, nos amparamos nos conceitos de reescrita e manipulação da fama literária, apresetados por André Lefevere. ${ }^{33}$ Em sua obra Tradução, reescrita e manipulação da fama literária, o autor adverte que trata dos intermediários, ou seja, "[...] homens e mulheres que não escrevem literatura, mas a reescrevem. ${ }^{34} \mathrm{O}$ autor expõe a importância de quem se ocupa de tal ofício pois “[...] são, no presente, co-responsáveis, em igual ou maior proporção que os escritores, pela recepção geral e pela sobrevivência de obras literárias entre leitores não-profissionais". ${ }^{35}$ Conscientes de que um autor como Ungaretti é dono de fama e estatura imensa e inquestionável, queremos, em nossa tese, nos valer da capacidade de forjar o conceito de reescritura enquanto seleção das cartas e interpretação do que chamamos de uma leitura possível, de uma cartografia proposta para ler as missivas. Temos a intenção de explicitar de forma consciente o que, em nosso recorte, aponta para certa poética ou "ideologia" (cujo critério de seleção passa, invariavelmente por alguma bússola inconsciente). Pensando com André Lefevere e Susan Bassnett, observamos como "[...] reescrituras podem introduzir novos conceitos, $[\ldots]$ gêneros, $[\ldots]$ artifícios $[\ldots]$ também da inovação literária, do poder formador de uma cultura sobre outra". ${ }^{36}$ Enquanto

\footnotetext{
${ }^{28}$ DIAZ, Brigitte. Gênero epistolar. O pensamento nômade. São Paulo: Edusp, 2016, p. 156.

${ }^{29}$ A autora se refere a Ricœur e o cita em nota de rodapé: "A mesmice é um conceito de relação e uma relação de relações". RICCEUR, Paul. Soi-même comme um autre. Paris: Seuil, 1990, p. 140 (Col. "L'ordre philosophique").

${ }^{30}$ DIAZ, Brigitte. Op. cit.. São Paulo: Edusp, 2016, p. 156.

31 Ibid.

${ }^{32}$ DIAZ, Brigitte. Gênero epistolar. O pensamento nômade. São Paulo: Edusp, 2016, p. 158

${ }^{33}$ LEVEFERE, André. Tradução e manipulação da fama literária. Bauru: Edusc, 2007.

34 Ibid., p. 13.

35 Ibid.

36 Ibid., p. 12.
} 
pesquisadora e tradutora, coloco-me como intermediária entre o descobrimento do arquivo e a apresentação do mesmo ao público brasileiro, ainda que tenha que admitir o fato de ocupar um duplo lugar ao ser também, eu mesma, autora, poeta e, por tal motivo, ter privilegiado o recorte que se apresenta nesta tese. Como aponta Lefevere em sua pesquisa:

[...] produzindo traduções, histórias da literatura ou suas próprias compilações mais compactas, obras de referência, antologias, críticas ou edições, reescritores adaptam, manipulam até um certo ponto os originais com os quais eles trabalham, normalmente para adequá-los à corrente, ou a uma das correntes ideológica ou poetológica dominante de sua época. ${ }^{37}$

Neste caso, talvez, usar o conceito de ideologia — tão carregado semanticamente — possa soar como um exagero, e certamente o é, tendo sido a palavra-conceito super-apropriada e vestida de um manto que denota certo uso negativo do termo; usa-se, por exemplo, popularmente a expressão “ideologia de gênero” para desqualificar reivindicações progressistas no cenário sociopolítico. Há, porém, que se admitir que até mesmo um recorte poetológico carrega em si uma política — ou intenção política — subjacente. O que nos interessa aqui, considerando o que nomeamos com Lejeune de espaço biográfico, é pensar a obra e a vida mescladas na representação que se oferece de cartas, um texto que é algo que, para além do espaço dito biográfico, pode, em parte, conter indicações de autoficção. Se as cartas podem servir como espaço para pensar e criar conceitos e poéticas, esse espaço em si mesmo pode ser digno de reclamar a denominação de uma obra, se o observamos sob a lente do contemporâneo. Não estamos aqui desapropriando o lugar das missivas ao tentar encaixá-las noutro subgênero — a autoficção — mas queremos, isso sim, nos apropriar, em alguma medida, desse recorte, levando em consideração que o gênero epistolar, como o define Diaz, é também a expressão de um pensamento nômade. Entre Ungaretti e Bruna, houve uma relação tanto epistolar quanto real e concreta, pois a correspondência registra algo — que vai além da relação em si — mas não registra tudo: também deixa um silêncio, algo em branco, algo que se cala. Os interstícios que separam uma carta da outra, uma vivência não registrada de um poema escrito, uma versão provisória de um texto do texto final; isso é algo que poderia ser representado alegoricamente com a observação que o escritor e pesquisador Julián Fuks tece em sua tese ${ }^{38}$ sobre o que o pó, resquício da pintura, representa para Max Ferber, uma personagem do escritor W.G. Sebald. Ferber, um

37 LEVEFERE, André. Tradução e manipulação da fama literária. Bauru: Edusc, 2007, p. 23.

38 FUKS, Júlian. História abstrata do romance. Tese de doutorado, FFLCH, USP: 2016, p. 132 (https://www.teses.usp.br/teses/disponiveis/8/8151/tde-14032017-160249/publico/2016_JulianMiguelBarberoFuks_VOrig.pdf, consultado em 14 de abril de 2019). 
pintor errático e melancólico, trabalha com a técnica de aplicar às suas telas um excesso de tinta para depois removê-la: o artista opera "[...] o tempo todo acometido pela suspeita de que o pó que se acumulava no chão [...] lhe era muito mais íntimo que a luz, ou o ar ou a água", ${ }^{39}$ como se o pó fosse "[...] o verdadeiro resultado de seus esforços continuados e a prova mais cabal de seu fracasso". ${ }^{40}$ Para Fuks, Sebald vale-se da escrita, como Ferber da pintura, dos “[...] resquícios indigentes que o real lhes concede para que possam compor uma ficção vívida". " Tentamos, em nosso recorte, também privilegiar algo deste resquício, algo que no fundo escapa, para tecer a capa freática de um leito de rio subterrâneo sobre o qual se inserem os principais temas que ocupam a escrita e a reflexão de Giuseppe Ungaretti.

O pacto com o leitor não profissional ${ }^{42}$ das cartas, seguindo aqui a definição de leitor profissional oferecida por Lefevere, é algo ditado pela curiosidade que se tem em saber mais sobre a esfera íntima de um escritor, esta revelação tardia e vouyerística da intimidade do poeta. Já para o leitor profissional, as cartas poderiam servir como arquivo de estudo para comparar a genética de textos literários, poemas ou, até mesmo, ideias que concernem sua visão sobre as artes plásticas. Mas o leitor profissional estaria isento da curiosidade que habita o leitor não profissional, aquele em busca de uma boa narrativa sobre uma história de amor?

É necessário forçar as fronteiras para que o que poderia se apresentar meramente como autobiográfico e voyerístico ocupe outro patamar — o pacto ficcional e fantasmático também pode ser observado nesta correpondência literária, talvez de forma mais explícita por se tratar de uma correspondência amorosa. A leitura crítica, segundo Diaz “[...] seria um desses inúmeros fantasmas que recobrem o percurso da carta, desviando-a para o infinito, os mesmos fantasmas que Kafka, evoca com terror resignado":43

\footnotetext{
${ }^{39}$ Ibid.

40 SEBALD, W.G. Os emigrantes. São Paulo: Cia. das Letras, 1992, p. 163-4. Apud FUKS, Julián. Op. cit. p. 132.

${ }^{41}$ FUKS, Júlian. História abstrata do romance. Tese de doutorado, FFLCH, USP: 2016, p. 132 (https://www.teses.usp.br/teses/disponiveis/8/8151/tde-14032017-160249/publico/2016_JulianMiguelBarberoFuks_VOrig.pdf, consultado em 14 de abril de 2019).

${ }^{42}$ Lefevere diferencia o leitor profissional do leitor não-profissional. O primeiro seria um leitor de "alta" literatura (de obras clássicas, professores e leitores da área de Letras, trabalhadores do mercado editorial) ou seja, alguém que possui uma influência maior nas instituições de ensino, crítico de literatura. O tipo de leitura consumida por um leitor nãoprofissional seria distinta, ou seja, livros seriam olhados sem essa análise crítica. Para Lefevere (2007), o leitor profissional é um professor ou estudante de literatura e se diferencia do leitor não-profissional por não viver apenas da cultura do livro adaptado ou reescrito para cinema, televisão e música. "No passado, assim como no presente, reescritores criaram imagens de um escritor, de uma obra, de um período, de um gênero e, às vezes, de toda uma literatura. Essas imagens existiam ao lado das originais com as quais elas competiam, mas as imagens sempre tenderam a alcançar mais pessoas do que o original correspondente e, assim, certamente o fazem hoje. No entanto, a criação dessas imagens e seu impacto não foram frequentemente estudados no passado e continua não sendo objeto de estudo detalhado. Isso é bastante estranho, uma vez que o poder exercido por elas e por seus produtores é enorme". (Lefevere, 2007, p. 18-19). ${ }^{43}$ DIAZ, Brigitte. Gênero epistolar. O pensamento nômade. São Paulo: Edusp, 2016 p. 14.
} 
Como pode ter surgido a ideia de que cartas dariam aos homens um meio de comunicação? Pode-se pensar em um ser longínquo, pode-se captar um ser próximo: o resto ultrapassa a força humana. Escrever cartas é se despir dos fantasmas: eles esperam por esse gesto com avidez. ${ }^{44}$

O questionamento de Sophia Angelides é sempre subjacente ao lidarmos com missivas: "Pode ser a carta lida e usufruída como obra de literatura, ou constitui apenas um material auxiliar para o conhecimento de seu autor, de problemas relacionados com a sua obra, de suas concepções e de seu ambiente social?" ${ }^{45}$ Seguindo Philippe Lejeune, as cartas ocupariam o espaço autobiográfico, mas ao ocupar este espaço não se retrairíam do campo literário, especialmente no caso do nosso corpus. As cartas de Ungaretti a Bruna certamente transcendem a definição de material auxiliar ao estudo de sua obra, como ressalta Lejeune: “[...] não se trata de buscar, aquém, uma inverificável semelhança com uma pessoa real, mas sim de ir além, para verificar, no texto crítico, o tipo de leitura que ela engendra, a crença que produz." 46

Voltando à leitura crítica, podemos levar em conta o que observa Paola Montefos$\mathrm{chi}^{47}$ sobre o movimento de enxertos literários dentro da obra de Ungaretti. Este mesmo movimento é possível de ser observado na tessitura das cartas: é o caso dos primeiros meses de correspondência, quando Ungaretti se apropriou da alguns poemas para "estar com Bruna", e assim, numa intenção de tradução, foi escrevendo seus próprios versos. No capítulo 3, observaremos com mais cuidado essa presença nas cartas. Sobre as fontes presentes na poética de Ungaretti, Montefoschi diz:

La presenza di fonti della poesia é quasi sempre esplicitamente dichiarata da Ungaretti, quando discorre di poetica o rievoca le varie epoche della sua formazione, quando complia meticoloso e provocatorio l'elenco dei suoi "maggiori" [...] Altre volte, però, probabili relazioni intertestuali, soltanto alluse o dissimulate o addirittura negate dal poeta, si manifestano al lettore per mezzo di minimi indizi, segnali di decifrazioni disseminati nel testo (echi, calchi, citazioni, pretiti lessicali). ${ }^{48}$

\footnotetext{
${ }^{44}$ KAFKA, Franz. Lettres à Milena. Paris: Gallimard, 1956, p.260. Apud DIAZ, Brigitte. Gênero epistolar. O pensamento nômade. São Paulo: Edusp, 2016, p. 14.

45 ANGELIDES, Sophia. Carta e Literatura. Correspondência entre Tchekhov e Gorki. São Paulo: Edusp, 2001, p. 15.

46 Ibid., op. cit., p. 47.

${ }^{47}$ MONTEFOSCHI, Paola. Ungaretti Le Eclissi della Memoria. Napoli/Roma: Edizioni Schientifiche Italiane, 1988, p. 9-39.

48 Ibid., op. cit., p. 9.
} 
Noutras palavras, há uma combinação de momentos em que Ungaretti revela explicitamente suas fontes, e outras em que podemos observar realações intertextuais, momentos em que as referências são dissimuladas e só podemos observar pequenos indícios. Montefoschi adverte, sobretudo, quanto ao perigo de como interpretar as informações dadas de forma explícita pelo autor e as outras, resgatadas através daquilo que ela chama de processo indiziario. Essa seria a medida de uma leitura crítica. Esse olhar assinalado por Montefoschi, associado aos parâmetros apontados por Lejeune e, mais adiante, também por Vincent Kaufmann, deverá servir como um crivo analítico. Montefoschi continua, ao explicar os dois tipos de enxertos textuais do poeta:

Nel primo caso, quello della piena confessione, l'individuazione dei vari rapporti refenziali è favorita, anche se va sottoposta a verifica perché, in generale, non è sempre opportuno dare pieno credito alle affabulazioni dei poeti. Nel secondo caso, quello del processo indiziario, la cautela del lettore deve esser estrema, considerando, tra l'altro, in quale misura un discorso sul sistema delle fonti ungarettiane coinvolga profondamente le "ragioni della poesia"del déraciné, che nei versi [...] di Italia ha indissolubilmente legato $[\ldots]$ la sua affermativa e responsabile pronuncia di poetica $[\ldots]$ al proprio nomadismo intelletuale: Sono un frutto/ dinnumerevoli contrasti d'innesti/ maturato in una serra. ${ }^{49}$

Com efeito, pensamos num olhar que conjugue o que Montefoschi descreve como uma posição dialética existente em Ungaretti em relação ao milieu cultural e literário, que ora privilegiava a dimensão europeia, sobretudo francesa, ora encontrava-se em sintonia com o ambiente italiano, ora se via como uma experiência poética apartada e plenamente autônoma em suas escolhas. Mais uma vez, relembramos que Lejeune, noutra edição da obra já citada, descreve a epístola como uma partilha ${ }^{50}$ que possui várias faces e expressões, apresentando três dessas faces, a saber: a carta como um objeto (que se troca), a carta como um ato (que coloca em destaque o "eu", o "ele" e os outros) e a carta como um texto (que se pode publicar). ${ }^{51}$

Dentro da divisão da carta enquanto objeto de troca, ato que define o eu e o outro e um texto que pode ser publicado, agregamos também a possibilidade de leitura destas ressaltando a rede de leituras do autor, suas relações e trocas que provocaram, durante o desenrolar desta relação epistolar, um pensamento crítico por vez traduzido em ensaios, por outras só contido nas cartas. Em alguma terra do meio, entre a memória e a inocência

\footnotetext{
${ }^{49}$ Ibid., op. cit. p. $9-10$.

50 Nos referimos aqui ao texto de abertura da revista Teresa, edição especial sobre cartas: EDITOR, O. Sobrescrito. Teresa, n. 8-9, p. x-xi, 18 dez. 2008.

${ }^{51}$ LEJEUNE, Philippe. Pour l'autobiographie. Chroniques. Paris: Seuil, 1998.
} 
que pairam em todo seu pensamento e obra, uma rede de relações e de ideias que é, talvez, complementar à sua disposição à solidão, o que Montefoschi denomina verginità intelettuale, ou seja, sua exigência por palavras ingênuas, cultivada como raiz de sua inspiração. ${ }^{52}$

\subsubsection{Reading in bed e o equívoco epistolar}

Vincent Kaufmann propõe uma leitura interessante para o estudo de cartas, ao afirmar que haveria um equívoco na interpretação do gesto epistolar. Embora, supostamente, a troca epistolar encoraje a comunicação e a proximidade, esta parece, de fato, desqualificar formas de partilha e aproximação, produzindo, ao contrário, uma distância, um afastamento necessário para que a própria correspondência aconteça. $\mathrm{O}$ que nos interessa no estudo de Kaufmann ${ }^{53}$ é o traço fronteiriço que emerge de suas observações a partir do estudo de correspondências entre escritores e seus interlocutores, pois o autor considera que as trocas epistolares analisadas (Flaubert, Baudelaire, Mallarmé, Valéry, Proust, Kafka, Rilke e Artaud) funcionaram como "laboratórios" à fronteira da escrita poética. Certamente, as cartas de Giuseppe Ungaretti a Bruna Bianco possuem a mesma qualidade, o mesmo traço. Nos capítulos 3 e 4, apontaremos em quais momentos o diálogo se transforma num laboratório criativo, seja no que diz respeito à criação poética, o surgimento da ideia do livro Dialogo, quanto no que diz repeito das questões tratadas em seus ensaios sobre artes plásticas.

Outro aspecto da pesquisa de Kaufmann que interessa destacar é o método analítico de leitura que ele propõe, ou, ainda, a dimensão analítica de aproximação ao texto. Segundo o autor, mais do que uma escolha teórica, ocorre impor uma limitação ou circunscrição para se olhar o texto, uma escolha que supõe, também, abertura aos equívocos de leitura. A reflexão do autor nasce de um episódio biográfico no qual, após apresentar o seu livro L'Equivoque epistolaire, um psicanalista presente na platéia lhe pergunta sobre seu método de leitura com a seguinte pergunta: "E como o senhor lê?”. À tal indagação, o pesquisador responde instintivamente, e talvez por isso provocando um ruído ou equívoco, que lia deitado. O interlocutor, obviamente, referia-se a um método, e não a uma posição física. No entanto, a partir deste equívoco, nasce uma reflexão em torno ao que seria uma leitura de inspiração (psic)analítica, ao que Kaufmann ${ }^{54}$ diz:

52 MONTEFOSCHI, Paola. Ungaretti Le Eclissi della Memoria. Napoli/Roma: Edizioni Schientifiche Italiane, 1988. p. 11.

53 KAUFMANN, Vincent. L’equivoque epistolaire. Paris: Les éditions de minuit, 1990.

${ }^{54}$ KAUFMANN, Vincent. Post Scripts. The Writer's Workshop. Tradução inglesa de Deborah Treisman. Cambridge (Massachusetts)/Londres: Harvard University Press, 1994. 
$[\ldots]$ reading a text from an analytical point of view requires the reader to occupy not only the position of the analyst - from whom he borrows a certain assumed knowledge - but also the position of the patient being analyzed, of the one who is there to express himself in words. Valéry once said that the poem listens to its reader. We could say more generally that reading a text in an analytical way, observing its gaps and repetitions, makes us its "analyst" but also puts us in a position to be analyzed or "spoken" by the text. 55

Os gaps e repetitions, ou seja, as lacunas e repetições que ocorrem neste compêndio epistolar são traçadas com mais atenção nos capítulos 3 e 4 . De toda maneira, é evidente que a mais frequente repetição é o chamamento amoroso, as juras de amor que ocorrem a cada carta escrita, assim como os nomes carinhosos que sofrem algumas alterações mas se repetem constantemente, repetem-se as narrativas do cotidiano (mesmo existindo uma grande variedade no cotidiano, devido a tantas viagens), repetem-se as listas em que o poeta classifica quem seriam os melhores artistas plásticos, os melhores escritores, os melhores poetas, os melhores tradutores. Repetem-se minuciosas listas com presentes enviados à amada, relatos em listas dos trabalhos que deve cumprir ou já cumpriu, das publicações em andamento. Seriam os encontros presencias, lacunas? A maior é certamente o desfecho da relação epistolar e não só, em 1969 a comunicação entre os dois se torna cada vez mais rarefeita, até no dia 14 de abril do mesmo ano, Bruna recebe a última carta de Ungaretti. Em relato conferido-me durante a transcrição das cartas, mostrou-me uma cópia da edição de luxo de Il Dolore, na qual se lê a derradeira dedicatória "Per Bruna indimenticabile/ Buon Natale / Buon Anno Ungà", e na segunda página 'L'amore mio per te / arde sempre, sotto la cenere /Ungà / Roma il 6 XII 1969”. Lacunares também os planos de viagens a serem feitas juntas, o desejo de uma união entre os dois - a impossibilidade de um fechamento claro, lacunar a dificuldade própria do período para se receberem cartas ou mesmo para se comunicarem por outros meios. Há enfim, no hiato, a presentificação da ausência.

\footnotetext{
${ }^{55}$ KAUfMANN, Vincent. Post Scripts. The Writer's Workshop. Tradução inglesa de Deborah Treisman. Seminário na Universidade de São Galo (https://www.unisg.ch/-/media/dateien/unisg/schools/shss/franzoesisch/vincentkaufmann_post-scripts.pdf, consultado em 14 de abril de 2019).
} 
Desde o princípio há lacuna, o hiato — trata-se, como vimos, de ausências comunicantes (Erasmo de Roterdã). Prosseguimos, portanto, um pouco mais pelo caminho a que Kaufmann nos conduz, ao estudar uma relação epistolar pela metáfora de uma relação analítica. O jogo de espera e ausência, entre os breves encontros, é graficamente bem representado no quadro Mulher de azul lendo uma carta, de Jan Vermeer, pintor muito amado por Giuseppe Ungaretti, ${ }^{56}$ ao qual nos dedicamos com mais espaço no capítulo 4, narrando como ele surge nas cartas a Bruna, enquanto o poeta pensava o texto que escreveria para a editora Rizzoli. Vermeer traduz esta atmosfera do espaço interior — nas palavras de Ungaretti: "nella stanza dove la gente è raccolta nei suoi pensieri’" — o interior em que as pessoas se recolhem com os seus pensamentos, com alguma analogia ao que nos apresenta o estudo de Kaufmann:

A psychoanalytical treatment and an epistolary exchange have several elements in common - the most significant being between the person to whom one writes, often over a period of years, and the analyst to whom one speaks, also over a period of several years. Both figures have an ambiguous or equivocal status. They are there without being there. The first cannot respond immediately and the second stops herself from doing so. They exist within a "depragmatized" discourse, floating between reality and fiction (or fantasy). Like the analyst, the correspondent exists as a listener. ${ }^{57}$

O correspondente existe como um ouvinte, a criação de uma escuta — real e imaginária — é necessária para que frutifique o espaço de troca, para que surjam as ideias e associações.

But in as much as she maintains a necessary silence, the speech ostensibly addressed to her drifts into the essential irresponsibility that is also necessary for desire to surface. By moving into the shadowy, your correspondent gives free reign to your imagination, to narcissism, to the mirror effect; she teaches you to enjoy the sound of your own voice. ${ }^{58}$

Como se pode observar, tanto na leitura das cartas traduzidas, quanto no capítulo onde propomos uma cartografia para esta leitura (capítulo 4), é este silêncio — a dificuldade de receber as cartas, o atraso, o descompasso entre os compromissos de Ungaretti e o trabalho de Bruna - que nos mostra um apanhado de vida que segue seu curso se forma não regular: "viver não é preciso", para extirpar um verso de Pessoa, e assim seguem as missivas, o espaço necessário para a emergência do desejo, seu deslocamento. As últimas cartas

\footnotetext{
56 Ungaretti relata em carta datada de Paris, 27 de novembro de 1966: “[...] Vermeer è un pittore sopratutto d'interni (e se leggi gli scritti da Amsterdan del mio 'Il deserto e dopo' vedrai che cosa è l'interno olandese. Pittura di somma calma, dove la luce vibra piano dai vetri — che cosa sono di meraviglioso i vetri illuminati in Vermeer — e produce lievi cadute, che non cadono, di ombre, nella stanza dove la gente è raccolta nei suoi pensieri e nel suo riposo". ${ }^{57}$ KAUfMANN, Vincent. Post Scripts. The Writer's Workshop. Tradução inglesa de Deborah Treisman. Seminário na Universidade de São Galo (https://www.unisg.ch/-/media/dateien/unisg/schools/shss/franzoesisch/vincentkaufmann_post-scripts.pdf, consultado em 14 de abril de 2019).

${ }^{58}$ KAUFMANN, Vincent. Post Scripts: The Writer's Workshop. Tradução inglesa de Deborah Treisman. Cambridge (Massachusetts)/Londres: Harvard University Press, 1994.
} 
de Ungaretti contém infinitas listas de compromissos e suas datas, versões de poemas e traduções de Vinícius, um tipo de silêncio preenchido com o pragmatism do cotidiano. $\mathrm{O}$ silêncio, ou talvez uma conversa escrita que se assemelhe, em seus dias finais, a uma linha cruzada numa ligação por telefone. Ainda que não tivemos a oportunidade de ler as cartas que Bruna Bianco recuperou, escritas por ela mesma, através da neta de Ungaretti, imaginamos que seja nessa releiutra que a interlocutora talvez tenha buscado aquilo a que Kaufmann se refere como "something akin to truth, and ot desire":

By remaining there, though, she also leads you to a point where the imagination exhausts itself, working in a void, it loses solidity, becomes removed from itself, as if watching an image of itself. Behind the requests entrusted to the mailman, in the spaces between the lines, lies something akin to truth, and to desire. ${ }^{59}$

Ungaretti è nella stanza raccolto nei suoi pensieri enquanto escreve a Bruna e coloca em relação seus pensamentos sobre a vida, a poesia, a tradução e a arte, além de relatar detalhadamente suas atividades de trabalho e suas viagens por diversas cidades. A condição de quem escreve uma carta é a de uma solidão "assistida", uma solidão exposta e em busca do olhar de sua interlocutora, Bruna Bianco, um olhar não direto mas sim distanciado no tempo: há aí, sem dúvida, algo de um amor transferencial ${ }^{60}$ que se instaura. Pensemos, por exemplo, nas palavras de Ungaretti, quando relata que uma sofrida e lacerante condição solitária é em alguma medida o contraponto para um "estado de graça", almejado e perseguido tanto na poesia como no desejo de encontro, a questão subjacente que o aflige é também a do pertencimento, esta impossibilidade de pertencer a uma tradição ou algum lugar que é repensada e reformulada de outro jeito, não como seu amigo Mohamed Sceab que não podia dissolver o canto do seu abandono - E non sapeva / sciogliere / il canto / del suo abandono - mas daquele que encontra a possibilidade do canto mesmo sendo sempre um homem só, um homem avulso, um homem expulso:

È uno stato di grazia che implica con crudeltà l'impossibilità di appartere a qualsiasi luogo, a una qualsiasi tradizione, a una qualsiasi realtà spiritualmente unificante, anche se, via via, crescendo negli anni e nell'arte, lungo la vita come scampo dalla pazzia, sia ricorso a illusioni $\mathrm{o}$, si dica pure, a surrogati. Le compagnie più amabili del mondo mi sono state concesse in tanto cammino della troppo lunga vita, ma non

\footnotetext{
${ }^{59}$ KAUfMANN, Vincent. Post Scripts: The Writer's Workshop. Tradução inglesa de Deborah Treisman. Cambridge (Massachusetts)/Londres: Harvard University Press, 1994.

${ }^{60}$ No ensaio "La memoria letteraria, gli innesti", op. cit., Montefoschi usa o termo transfert ao abordar certas características de movimentos do poeta em relação a seu processo criativo, por exemplo, e diz, ao comentar a citação que segue em nosso texto: "Questa confessione fornisce la chiave per decifare i modi in cui le ragioni di Ungaretti lettore, critico, teorico della letteratura si organizzino attorno alle domande della sua poesia. Alla luce di tali considerazioni si giustifica infatti il tono coinvolto, tormentanto di alcune sue letture e interpretazioni, non tutte ortodosse, che si qualificano come veri e propri transfert identificativi, tentativi di riconoscimento e di autodeterminazione trasversali" (p. 13).
} 
c'è mai stato legame al mondo, per quanto m'avvincesse la sua profondità, che potesse fare di me non più un uomo solo, un uomo separato, un uomo avulso, uno uomo espulso. ${ }^{61}$

Há, no endereçamento a Bruna, se não a esperança, pelo menos, em parte, de uma saída daquela condição, um desejo que se insinua, como por exemplo, o retorno à escrita após um hiato de seis anos em que Ungaretti não escreveu poemas. Há uma presença ausente e também imaginada que impulsiona a criatividade e a intensidade dessa correspondência amorosa: é como se nosso poeta procurasse o leitor ideal que Kaufmann descreve como “o leitor ausente". Noutras palavras:

To the ideal or implicit readers assumed by the aesthetics of reception, ${ }^{62}$ and to the readers with whom, whether in accordance with Bakhtin or not, one maintains a dialogic relationship, I propose to add another kind of reader: not a partner in dialogue, and even less a partner in a trivia game $[\ldots]$, but a desired reader who is fundamentally absent. ${ }^{63}$

Um leitor desejado que seja ausente; quanto mais se aproxima a perspectiva de uma vida comum, conjugada, de uma mais longa permanência, mais se rarefaz a escrita das cartas pelo menos é o que observamos entre às enviadas de Ungaretti para Bruna.

As cartas de Kafka, Proust, Flaubert, Baudelaire, Rilke e Valéry analisadas por Kaufmann são textos literários, ainda que fronteiriços, assim como no caso de nosso objeto de estudo. É pertinente, portanto, tentar entender qual é esse novo paradigma de leitor que tenta forjar o estudioso e de que forma este exemplo pode iluminar um caminho, ou revelar uma urdidura, a ser seguida na leitura do epistolário amoroso ungarettiano. Há, segundo Kaufmann, um interesse primário na correspondência de um escritor, por fazer com que o outro desapareça - a ponto de poder ele mesmo desaparecer. Numa perspectiva lacaniana, poder dizer que o que define o texto literário é a habilidade de endereçar, antes e para além do outro imaginário (que é sempre semelhante a si mesmo), um Outro que é a causa e a fonte do desejo. Segundo a fórmula que o autor elabora ao tratar da correspondência de Kafka, é a habilidade de endereçar-se a ninguém, sendo esse, porém, um "ninguém" em particular. ${ }^{64}$ Kaufmann quer contrapor, a um pensamento dialógico e hermenêutico, aquilo que denomina de "pensamento epistolar". ${ }^{65}$ A dimensão de ausência pode também vir ao

\footnotetext{
61 Citação de Ungaretti apud PICCIONI, Leone. Vita di Ungaretti. Milão: Rizzoli, 1979, p. 57, in MONTEFOSCHI, Paola. Ungaretti Le Eclissi della Memoria. Napoli/Roma: Edizioni Schientifiche Italiane, 1988. p. 12.

62 Em seu texto, Kaufmann refere-se aos seguintes autores em sua nota: "I am thinking specifically of the works of the Ecole de Constance, most notably those of H.-R. Jauss and W. Iser".

63 KAUFMANN, Vincent. Post Scripts. The Writer's Workshop. Tradução inglesa de Deborah Treisman. Cambridge (Massachusetts)/Londres: Harvard University Press, 1994.

64 Ibid.

65 "In short, I want to play the epistolary against the dialogic and the hermeneutic. It may not seem a particularly timely
} 
encontro do que Lejeune havia descrito como pacto fantasmático. ${ }^{66}$ Talvez pudéssemos retornar à reflexão de Kafka, que apontamos anteriormente em nossa leitura de Brigitte Diaz, a propósito da relação entre cartas e fantasmas, em que o autor se pergunta:

Como foi que neste mundo alguém chegou à ideia de que pessoas podem se comunicar umas com as outras através de cartas?! Podemos pensar sobre uma pessoa distante, e podemos agarrar uma pessoa que está próxima - tudo o mais vai além da força humana. Escrever cartas, entretanto, significa desnudar-se diante de fantasmas, algo pelo qual eles aguardam avidamente. Beijos escritos, em vez de alcançarem seu destino, são bebidos no caminho pelos fantasmas. É a partir desta nutrição abundante que eles se multiplicam tão enormemente. A humanidade o pressente e resiste e, buscando eliminar ao máximo o elemento entre as pessoas, e criando uma comunicação natural, a paz das almas, ela inventou a ferrovia, o carro motorizado, o avião. Mas já não adianta, essas são invenção criadas evidentemente já no momento do estrondo. $\mathrm{O}$ lado opositor é tão mais calmo e forte; depois do serviço postal ele inventou o telégrafo, o telefone, o rádio. Os fantasmas não passarão fome, mas nós iremos perecer. ${ }^{67}$

\subsubsection{Retorno ao biográfico ou autobiográfico?}

O volume organizado por Walnice Nogueira Galvão e Nádia Batella Gotlib, ${ }^{68}$ há quase duas décadas, nos oferece um excelente panorama do interesse pelos estudos de missivas de diversos pesquisadores brasileiros, sobre autores nacionais e também estrangeiros. Com o tempo e com o advento cada mais veloz da tecnologia digital, as cartas parecem adquirir um status de preciosismo, talvez por tornarem-se agora não apenas raras como por correrem o risco de não mais existir, no presente, como campo e possibilidade de estudo na literatura futura. ${ }^{69}$ Certamente, há de se concordar com Galvão quando declara que podemos ter nas cartas:

1) Elementos preciosos para a reconstituição de percursos de vida.

2) Fontes de ideias e de teorias não comprometidas pela forma estética

3) Em certos casos ainda - como os de Madame de Sévigné, Lady Montagu e Sóror Mariana Alcoforado — um estatuto exclusivo devido à qualidade impecável da escrita. ${ }^{70}$

\footnotetext{
debate, but I am not convinced that it isn't — especially in an academic context that places so much importance on fixed cultural identities and seems generally uninterested in the disappearance of the reader or the writer. Evidence, impassivity and irresponsibility are not highly valued these days." Ibid., op. cit.

66 Referência citada e elaborada na nota 16.

${ }^{67}$ Apud BUTLER, Judith. "Uma poética de não chegada", traduzido por Tomaz Amorim Izabel. São Paulo, Cult, ed. 194 (http:/ / revistacult.uol.com.br/home/2014/11/uma-poetica-da-nao-chegada/, consultado em 7 de dezembro de 2016).

${ }^{68}$ GALVÃO, Walnice Nogueira. GOTLIB, Nádia Batella (orgs.). Prezado senhor, Prezada Senhora. Estudo sobre cartas. São Paulo: Cia. das Letras, 2000.

${ }^{69}$ GALVÃO, Walnice Nogueira. À margem da carta. Entrevista concedida à revista Teresa. São Paulo, Universidade São Paulo, 2008 (www.periodicos.usp.br/teresa/article/download/116656/114243, consultada em 20 de dezembro de 2016).

${ }^{70}$ GALVÃO, Walnice Nogueira. A margem da Carta. São Paulo, Universidade de São Paulo, Revista manuscrita, n. 7, 1998 (http://revistas.fflch.usp.br/manuscritica/article/view/882/799, consultado em 20 de dezembro de 2016).
} 
Temos, em nosso objeto de estudo, uma espécie de fusão entre esses três elementos descritos pela pesquisadora, pois há, nalgumas cartas, não só um comprometimento estético, mas a busca pelo texto final — particularmente os poemas que nascem a partir das traduções, bem como os poemas inéditos que são escritos e em alguma ocasião "saltam da página", ou seja, saltam da forma em prosa para transmutar-se em verso, como por exemplo na Carta n. ${ }^{\circ}$ 356, datada de 15 de janeiro de 1969 , em que Ungaretti escreve: ${ }^{71}$

Caro amore mio, questa lettera è piena di "cose pratiche".

Ma l'amore per Te mi riabilita, amore, e, se in qualche tuo segreto Ti pare a volte d'essermi sfuggita, Ti scopro che T'inganni, anima mia. La purezza tornandomi negli occhi. Ti bacio, sulle Tue labbra che ricorderanno sempre alle mie che mi ami per sempre. Per sempre. Ti bacio.

[a margine del quinto foglio]

Ma l'amore per Te,

Mi riabilita, amore,

E se, in qualche Tuo segreto,

Ti pare, a volte,

D'essermi sfuggita,

Ti scopro che T'inganni, anima mia,

La purezza tornandomi negli occhi.

As cartas que Ungaretti escreveu a Bruna Bianco certamente nos ajudam na reconstituição de algumas questões e alguns percursos de sua vida: as viagens a trabalho nos últimos anos de sua vida, os convites para leituras, as colaborações com instituições, os seminários nacionais e internacionais, assim como um relato minucioso sobre as relações que manteve com outros artistas naquele período, quando foram suas férias, onde se deslocou e o que lia, traduzia, escrevia e organizava naquele período, e com qual colaborador estava trabalhando. De fato, alguns dos volumes mais conhecidos sobre a obra de Ungaretti, na coleção "Meridiani” da editora Mondadori, foram também preparados naqueles anos, com o auxílio, por exemplo, de Mario Diacono, mencionado inúmeras vezes em suas missivas. As cartas, então, testemunham, por vezes, as fontes de ideias e teorias, especialmente no que diz respeito à sua poética e à sua poética da tradução, mas não se poderia dizê-las "não comprometidas pela forma estética", sendo impossível desagregar conteúdo e forma, já

\footnotetext{
${ }^{71}$ Inserimos na tese o texto em italiano, ainda que a carta esteja traduzida, para explicitar com mais força a questão que apontamos do poema que "salta da página, salta da prosa": Segue a tradução deste trecho da carta: "Querido amor meu, esta carta está cheia de 'coisas práticas'. / Mas o amor por Ti me reestabelece, amor, e, se em algum segredo teu Te parece que às vezes me foges, descubro-Te que Te enganas, alma minha. A pureza voltando-me aos olhos. Beijo-te, nos Teus lábios que recordarão sempre aos meus que me amas para sempre. Para sempre. Te beijo / Unga. [à margem da quinta página] mas o amor por Ti, / Me reabilita, amor, /E se, em algum segredo Teu, / Parece-te, por vez, /De ter-me fugido, / Te descubro que Te enganas, alma minha, / A pureza voltando-me aos olhos." [Carta n. ${ }^{\circ} 365$, datada de 15 de janeiro de 1969].
} 
que a qualidade literária intrínseca é um objeto em si. Por fim, um inegável "estatuto especial devido à qualidade das cartas", não só pelos poemas que surgem nesta troca epistolar, mas também pela gênese de ideias, há sempre a comoção do poeta diante do mundo e da vida, dado que se insinua nas linhas e entrelinhas de cada carta endereçada a Bruna.

Pertinente é também refletirmos não só sobre o peso que as cartas podem assumir dentro dos estudos literários, mas também sobre o tipo de pesquisador que deseja se ocupar de questões fronteiriças que transitam pelos campos da biografia, da autobiografia, da produção literária, algo que pertence também ao campo da genética textual que emerge, para os estudos literários, com força nos anos de $1980 .{ }^{72}$ Segundo Galvão:

[...] o surgimento da genética textual nos anos 80 tem muito a ver com este tipo de impulso, exasperado pela ameaça de obliteração de versões e variantes trazida pelo uso do computador. Sem esquecer a chamada "cultura do Eu", típica deste fin-de-siècle tão narcisista, em que a edição de epistolografia se acopla a uma produção autobiográfica sem paralelos em épocas anteriores. ${ }^{73}$

Enfim, se pensarmos a epistolografia também como um campo híbrido, contendo um claro valor literário e também situando-se entre a biografia e a autobiografia, poderíamos considerar a expansão que Lejeune faz à definição deste termo na revisão de $O$ pacto autobiográfico. $\mathrm{O}$ autor adverte que a palavra foi importada da Inglaterra (para o francês) no início do século XIX, e empregada em dois sentidos próximos, mas mesmo assim diferentes. O autor escolheu adotar o primeiro sentido, proposto por Larousse, em 1886: "vida de um indivíduo escrita por ele próprio". ${ }^{44}$ Segundo Lejeune, Larousse contrapõe à autobiografia as memórias que contam fatos que podem ser alheios ao narrador e, ainda num sentido mais amplo, diz que a "antobiografia pode designar também qualquer texto em que o autor parece expressar sua vida ou seus sentimentos, quaisquer que sejam a forma do texto e o contrato proposto por ele." ${ }^{, 75}$ Lejeune apresenta, então, outra definição, dessa vez anterior, do Dictionnaire universel des littératures (1876), que diz: “Autobiografia [...] obra literária, romance, poema, tratado filosófico etc., cujo autor teve a intenção, secreta ou confessa, de contar sua vida, de expor seus pensamentos ou de expressar seus sentimentos."76

\footnotetext{
72 Ibid., op. cit., p. 50-51.

${ }^{73}$ Galvão coloca a seguinte nota em seu texto, justamente retomando o que está implícito em nosso subtítulo — "biografia ou autobiografia?" - que é inspirado nos textos de Philippe Lejeune. A autora diz: "Não é por coincidência que Philippe Lejeune deu a um de seus livros o maldoso título de Moi aussi (Paris, Seuil, 1986). Vide, do mesmo autor: Le pacte autobiographique. Paris: Seuil, 1975; e Je est un autre. L'autobiopraphie, de la littérature aux médias. Paris: Seuil, 1980."

74 Apud LEJEUNE, Philippe. Op. cit., p. 53.

75 Ibid.

${ }^{76} \mathrm{Ibid}$.
} 
Diríamos, portanto, que, seguindo esta definição, aproximamos nosso objeto de estudo a essa categoria. Com este raciocínio, Lejeune coloca também em evidência a responsabilidade que o leitor deve assumir diante do texto, pois, se a intenção do autor for secreta, diz ele, quem decidirá de fato a intenção será o leitor. ${ }^{77}$ Este jogo, este pacto, fica bem evidente ao lermos as cartas que Ungaretti endereçou a Bruna. Inaugura-se, a partir dessa definição, uma nova forma de escrita, mas também de leitura, e diz ainda, citando Vapereau: “[...] a autobiografia abre um grande espaço à fantasia e quem a escreve não é absolutamente obrigado a ser exato quanto aos fatos, como nas Memórias, ou a dizer toda a verdade, como nas confissões". ${ }^{78}$ Claro que, se considerarmos que este é um comentário e uma definição de 1876, entenderemos que, de fato, para aquele momento, talvez não se questionasse, da mesma forma que se faz na época contemporânea, a veracidade de memórias e confissões. Hoje, seria difícil abordar confissões e memória sem pensarmos no ato imaginativo que está presente em cada esforço que se faz para recordar algo — na ausência e distância algo se inventa, algo se recria. Porém, para não nos afastarmos demais da nossa discussão, voltemos a outras considerações apontadas na literatura epistolográfica sobre este campo de estudo, e sua ambivalência.

Galvão fala do estudioso de cartas como um “amador”, dizendo que muitas vezes se chega até elas por acaso e este "acaso [...] logo se metamorfoseia em necessidade", ${ }^{79}$ ou seja, há uma clara distinção entre o uso de cartas enquanto proto- e paratextos, e o deslocamento das mesmas para o lugar central de objeto de pesquisa. Há um inconfessável prazer dúbio próprio do voyeur, segundo a autora. "O coração do amador de cartas se confrange ante a impossibilidade de reparar o irremediável” — nos diz Galvão — "cogita-se no gesto admirável dos familiares, ao curvar-se ante a importância dos documentos e abrir mão deles, por mais íntimos e [...] dolorosos que fossem. Torna-se compreensível, então, uma vacilação residual de resguardo".$^{80}$ Embora Bruna tenha resgatado suas próprias cartas — que seguiam guardadas na casa em que Ungaretti morou na rua Sierra Nevada, em Roma — através de Anna Lafragola, neta do poeta, ela até o presente não as disponibilizou para nossa leitura, nem para leitura de outrem.

Haverá sempre algo que nos escapa e, afinal, escolhemos apresentar um recorte que privilegia o primeiro período de correspondência entre os dois. Nos primeiros meses em que Ungaretti e Bruna se corresponderam, entre setembro de 1966 e abril de 1967, as cartas são

\footnotetext{
77 Ibid.

78 Ibid., op. cit., p. 54.

${ }^{79}$ GALVÃO, Walnice Nogueira. A margem da Carta. São Paulo, Universidade de São Paulo, Revista manuscrita, n. 7, 1998, p. 50 (http://revistas.fflch.usp.br/manuscritica/article/view/882/799, consultado em 20 de dezembro de 2016.

${ }^{80}$ Ibid., op. cit., p. 51.
} 
não só mais frequentes, mas contêm o mais denso conteúdo literário, pois trata-se da gênese do livro Dialogo. É nestes oito primeiros meses que se consolida a relação, que Ungaretti começa a incentivar a escrita de Bruna, corrigir seus poemas, dialogar sobre a língua, escrever seus próprios poemas endereçados à amada fazendo uso da tradução como gesto propulsor da criação. Muitos dos temas se repetem ao longo das cartas, alguns se tornam mais rarefeitos com o tempo. Ainda que tenham sido incluídas cartas de outros períodos, de outros anos, privilegiamos o recorte do início da relação amorosa e epistolar, por tratar-se do período mais fértil no campo poético e também das ideias. No quarto capítulo, o que contém as cartas selecionadas traduzidas e anotadas, propomos uma cartografia para navegar as missivas, ou seja, nossa particular leitura possível dentro de um diálogo "entre duas ausências".

Algo de lacuna e desencontro, e também de ausência, é intrínseco à natureza das cartas, talvez algo que se acentue nas missivas de amor — são cartas dessa índole que compõem aqui o nosso objeto de estudo. O primeiro texto da coletânea organizada por Walnice Nogueira Galvão é um texto ficcional — ou, poderíamos dizer, talvez ficcionalmente autobiográfico, para borrar ainda mais nossas fronteiras - escrito pelo poeta português Ernesto de Melo e Castro e dedicado à companheira Elza Miné, professora e pesquisadora que também possui um texto no mesmo volume. O desfecho desta minicoletânea de missivas ordenadas por Melo e Castro possui o título "Carta de amor", e ele diz:

[...] espero que não saibas ler estas palavras que te são dirigidas, tal como sempre soubeste ler as que não soube dirigir-te.

[...] espero que um pouco de mim ressurja da linha do horizonte enquanto os galos não cantam nem os olhos vêem.

$[\ldots]$ numa noturna sensação de não saber se no escuro espero que não leias (esta carta). ${ }^{81}$

Melo e Castro, talvez com um pacto romanesco à la Lejeune, tenha ficcionalmente tocado a verdade sobre incompletudes, pois o não dito também deve ser lido. Na distância de meio século, o não dito da carta final de Ungaretti é algo que pode ser lido, intimamente, somente por sua interlocutora e amada Bruna — nós, leitores e pesquisadores, podemos da possa parte oferecer somente um recorte que insinue uma chave de leitura dentro deste compêndio.

Como já tentamos descrever neste capítulo, quando tratamos de estudar, e também traduzir, um acervo epistolográfico, caminhamos pelos territórios fronteiriços da biografia, da autobiografia e da escrita literária; por esse motivo, também nos parece interessante, mais uma vez, tentar entender as colocações de Vincent Kaufmann em seu livro L'equivoque

\footnotetext{
${ }^{81}$ GALVÃO, Walnice Nogueira. GOTLIB, Nádia Batella (orgs.). Prezado senhor, Prezada Senhora. Estudo sobre cartas. São Paulo: Cia. das Letras, 2000, p. 17.
} 
epistolaire, no que diz respeito a uma reatualização da questão biográfica. O autor tenta trilhar outro caminho que não aquele que afirma que "a obra fala por si" ou aquele que sustenta "a morte do autor" propostos por Blanchot, Barthes e Foucault. ${ }^{82}$ Kaufmann diz que em vez de "[...] se curvar aos mitos tanatográficos que continuam a construir a derradeira legitimidade do discurso literário” prefere, então, reatualizar a questão biográfica, “[...] mais precisamente, tentar demonstrar que o tanatográfico é apenas uma variante, ou a outra face da medalha, do biográfico". ${ }^{83}$ Após um período em que se viveu uma espécie de "guerra fria" entre vida e obra, cujas fronteiras eram bem fechadas, é possível agora, segundo Kaufmann, manter outro olhar complementar em relação às duas coisas, sendo as cartas objetos fundamentais para integrar essa perspectiva. Ele diz:

"[...] letters are a passage between the lived and the written, independent of their potential aesthetic value. They position and keep the writer's life within the literary sphere. The letter writer is thus the infamous missing link between the person and the work, the yeti of literature." 84

É através de uma metáfora humorística, na qual as cartas se tornam "O abominável homem das neves", que o autor tenta situar sua discussão em relação ao espaço literário proposto por Blanchot, tentando se contrapor, em alguma medida, a ele e a outros autores do pósestruturalismo. ${ }^{85} \mathrm{Um}$ passo arriscado, talvez, mas que aponta para uma direção algo desafiadora. A questão de um espaço autossuficiente para a produção literária é o que mais parece incomodar Kaufmann. Segundo Blanchot, a literatura é plural por abdicar da verdade previamente estabelecida no meio social em favor da ambiguidade na elaboração de seu próprio espaço discursivo. Desse modo, se subtrai a ideia de literatura enquanto decalque do mundo para privilegiar-se a ideia de literatura enquanto espaço autossuficiente, ${ }^{86}$ espaço cujas leis e regras são distintas das regras estipuladas pelo mundo em que vivemos. A literatura não serve para algo. A literatura não é um simples reflexo do mundo. A literatura não é apenas um meio de expressão do mundo. A literatura é: “a obra - a obra de

\footnotetext{
$82 \mathrm{O}$ autor faz essa declaração no texto da edição americana: KAUFMANN, Vincent. Post Scripts. The Writer's Workshop. Tradução inglesa de Deborah Treisman. Cambridge (Massachusetts)/Londres: Harvard University Press, 1994.

83 Ibid., tradução nossa.

84 Ibid., op. cit.

85 A diretriz tomada pelo escritor francês Maurice Blanchot em sua análise do espaço literário pode ser enquadrada, por ora, no que atualmente se denomina de pós-estruturalismo. No contexto literário, o ponto central da abordagem pósestruturalista é o desenvolvimento de um pensamento voltado para o texto, para a configuração estrutural da narrativa, para a análise desconstrucionista e performática da palavra, liberando o texto para uma pluralidade de sentidos. 86 Pensamos aqui também numa ligação com Barthes, "Nessa perspectiva a leitura é verdadeiramente uma produção: não mais de imagens interiores, de projeções, de fantasias, mas, literalmente, de trabalho: o produto (consumido) é devolvido em produção, em promessa, em desejo de produção, e a cadeia dos desejos começa a desenrolar-se, cada leitura valendo pela escritura que ela gera, até o infinito. (BARTHES, Roland. O rumor da língua. São Paulo: Martins Fontes, 2004, p. 40).
} 
arte, a obra literária — não é acabada nem inacabada: ela é. O que ela nos diz é exclusivamente isso: que é — e nada mais. Fora disso, não é nada. Quem quer fazê-la exprimir algo mais, nada encontra, descobre que ela nada exprime" ${ }^{87}$ Kaufmann questiona o espaço literário separado, quase sagrado, pois observa que isto lhe confere uma qualidade de mito. Sobre o pensador francês ele diz:

Maurice Blanchot was, to my knowledge, the first to note that "A La recherche du temps perdu" was the result of Proust's epistolary apprenticeship. But it was a theory he did not linger over or try to document; not, of course, because he was unable to but because the myth, or his myth, of writing wanted it that way. 88

Ainda para Kaufmann, para dar plena credibilidade à ideia de "solidão essencial", ou separar radicalmente o espaço literário, que não tem nada a ver com a "palavra não refinada" da qual fala Mallarmé, ${ }^{89}$ há de se assumir uma entrada na escrita e tentar evitar a discussão das especificidades da singularidade desta entrada: “[...] sempre haverá um ponto em que a escrita se torna sagrada, um lugar de encontro, invisível e indescritível, entre a profanidade das palavras não refinadas e a santidade das palavras essenciais." ${ }^{90}$ Por este motivo, apresentar a figura do escritor de cartas num palco que é território fronteiriço da literatura, dessacralizando o espaço literário sem destruir sua especificidade. Para o autor, é necessário transformar esse espaço literário em algo que possa ir além do mito com o qual é associado, já que o mito, por definição, resiste à singularidade e à subjetividade.

Ir além do mito do espaço literário, para Kaufmann, é uma revindicação que ganha força com o tipo de escrita epistolar, na qual estão presentes uma multiplicidade de figuras e representações, numa espécie de cruzamento entre a vida e a obra. De acordo com o autor, a correspondência de um escritor existe a partir do lugar em que esta pode criar um elo entre a vida e a obra. Por conseguinte, cada leitura pode descobrir quais elos estão presentes, cada correspondência de cada autor com cada interlocutor apresenta sua montagem e encaixe com certo momento do seu trabalho. O que tentamos apresentar nesta tese é a nossa leitura, especialmente nos capítulos 3 e 4, o nosso recorte a partir das cartas de Ungaretti enviadas a Bruna entre 1966 e 1969.

Enfim, ao transitarmos por estas considerações ao redor do gênero epistolar, é impossível não lançar nosso olhar um pouco mais adiante para imaginar o futuro, aquele já

\footnotetext{
${ }^{87}$ BLANCHOT, Maurice. O espaço literário. Rio de Janeiro: Rocco, 1987, p. 12.

${ }^{88}$ KAUfMANN, Vincent. Post Scripts. The Writer's Workshop. Tradução inglesa de Deborah Treisman. Cambridge (Massachusetts)/Londres: Harvard University Press, 1994.

${ }^{89} \mathrm{Ibid}$. a citação decorre do texto de Kaufmann, porém sugerimos aqui a leitura do seguinte artigo: JEAN ABES, Gilles. Uma tradução de "crise de verso" de Mallarmé: a ótica do enigma como símbolo do texto literário. São Paulo, Universidade de São Paulo, Revista TradTerm, n. 6, 2010, p. 149-174.

${ }^{90}$ Ibid.
} 
contido em nosso prsente, não tanto das cartas, mas sim desse tipo de comunicação interpessoal. Nesse sentido, o advento das inovações tecnológicas trouxe também uma mudança no tipo de relação possível entre os escritores e seus correspondentes. Quase vinte anos após o artigo de Walnice Nogueira Galvão, o cenário é ainda mais complexo e multimidiático do que se supunha. Naquele momento, parecia ser o fax o que havia proporcionado "novo fôlego ao manuscrito, viabilizando queimar as etapas de uma digitação e impressão morosa para pequenas mensagens pessoais". ${ }^{91}$ Cogitava-se a possibilidade de consequências imprevisíveis com o advento da internet, e hoje sabemos que, muito mais do que a comunicação por correio eletrônico (e-mail), são as redes sociais que imprimem uma nova forma de comunicação também entre os escritores e seus leitores.

Há uma mudança radical no que se compreende como exposição pública através do virtual, a noção do escritor personagem e não só autor parece ser uma realidade. Existiria, hoje, o poeta e o escritor que não estão presentes nas redes sociais?

\footnotetext{
${ }^{91}$ GALVÃO, Walnice Nogueira. A margem da Carta. São Paulo, Universidade de São Paulo, Manuscrita, n. 7, 1998,
} p. 53 (http://revistas.fflch.usp.br/manuscritica/article/view/882/799, consultado em 20 de dezembro de 2016. 



\section{2 ESTRUTURA E RECORTE DO ARQUIVO}

2.1 ESTRUTURA DO ARQUIVO

2.2 RECORTE 



\subsection{ESTRUTURA DO ARQUIVO}

[...] uma carta comunica sua mensagem não somente pelo texto que propõe, mas também pela multiplicidade dos signos que acompanham o texto: a forma da escrita, a ocupação do espaço da página, o número de folhas, os acréscimos colocados nas margens, a assinatura. ${ }^{92}$

Começamos a trabalhar em 2013 na organização, transcrição, anotação e catalogação das cartas enviadas por Giuseppe Ungaretti a Bruna Bianco. Após a conclusão da transcrição, em março de 2015, Bruna decidiu depositar as cartas num fundo na Fondazione Mondadori, portanto, quase todas as cartas encontram-se neste fundo e podem, atualmente, ser consultadas com agendamento prévio. Algumas cartas permanecem com Bruna. Em seguida, trabalhei auxiliando o professor Silvio Ramat com as notas de edição do volume publicado em setembro de 2017 pela Mondadori, na coleção “Oscar”, com o título Lettere a Bruna. A transcrição das trezentas e oitenta e seis cartas e dois telegramas, bem como a releitura com controle dos manuscritos, durou cerca de dois anos. Nos reuníamos, Bruna e eu, todas as sextas-feiras em seu domicílio. O material foi lido e transcrito na casa de Bruna Bianco, na sua presença, enquanto as anotações foram feitas em meu domicílio, fora do horário de trabalho conjunto. Trabalhei sob sua observação todas as sextas-feiras entre as 9 e 17 horas. Bruna me ditava o conteúdo das cartas enquanto eu as transcrevia, e o trabalho era interrompido com frequência para que eu pudesse olhar o manuscrito e verificar o conteúdo, bem como o desenho do texto espalhado pela página. Esse procedimento de controle de cada carta manuscrita foi repetido três vezes.

Seguindo as diretrizes de Pagés ${ }^{93}$ sobre a materialidade da carta, apresentamos aqui algumas indicações sobre o estado do arquivo e os critérios adotados para a transcrição e análise. Ao falar da centralidade da materialidade das cartas, o autor começa apontando a importância já do envelope - lá onde a carta está contida. Por sorte, quase todas as cartas enviadas por Ungaretti a Bruna foi conservadas assim, exceto as primeiras dez que haviam já sido transcritas. Segundo Pagés:

O envelope contém a carta. Fina barreira de papel que protege o segredo da comunicação. Abrimos para descobrir o texto ali contido. Mas, tal qual, antes mesmo de ser deslacrado, o envelope entrega uma mensagem à pessoa que o segura nas mãos: a escrita, o nome, o endereço redigido ou não de forma completa. Em se tratando do futuro editor (caso tenha ele a sorte de dispor desse precioso documento, muitas vezes lamentavelmente destruído), uma indicação essencial é fornecida pelo carimbo postal quanto este registra uma data às vezes ausente da própria

92 PAGÈS, A. A materialidade epistolar. O que nos dizem os manuscritos autógrafos. Revista do Instituto de Estudos Brasileiros, n. 67, p. 106-123, 31 ago. 2017.

${ }_{93}^{3}$ Ibid. 
carta manuscrita. Será que as linhas inscritas no retângulo do envelope (também chamado de "sobrescrito" — etimologicamente "a escrita em cima"...) não poderiam ser consideradas como introdução da carta? No entanto, essas linhas são sistematicamente apagadas de todas as edições de correspondência. ${ }^{94}$

A conservação dos envelopes foi importante para corrigir as datas que, nas cartas, estavam escritas incorretamente, assim como controlar a data das poucas missivas que não continham a data em que foram escritas. Outro aspecto importante foi controlar qual o endereço apresentado pelo remetente, já que Giuseppe Ungaretti viajava muito, ausentava-se de Roma e esperava que Bruna continuasse e lhe escrever, desta forma fornecia à amada, muitas vezes, o endereço de amigos ou assistentes - Mario Diacono, por exemplo. Durante as viagens de Ungaretti a Paris, Londres, Israel e Suécia, as cartas de Bruna eram guardadas em Roma, no endereço indicado.

Outro aspecto importante apontado por Pagés, em seu estudo sobre as missivas de Zola, é a observação da grafia do autor:

É pelo encantamento de sua escrita, antes mesmo de ser decifrada, que uma carta se oferece ao olhar. A beleza de um manuscrito autógrafo reside, acima de tudo, em sua aparência escritural. Como um rosto que convida à contemplação, essa beleza compõe-se de diversos parâmetros: a regularidade ou a irregularidade das linhas, o legível ou o ilegível, os caracteres estreitos ou mais espaçados, a tinta mais fosca ou nítida, a cor (preta, vermelha ou azul)... Os manuscritos autógrafos mais notáveis são aqueles que mantiveram, a despeito dos anos passados, uma parte de juventude: guardaram todo o seu frescor. ${ }^{95}$

As cartas foram escritas em folhas com tamanho A4, por vezes em folhas menores, sempre um tipo de papel muito fino, normalmente uma só face era escrita pois a marcante tinta verde da caneta tinteiro penetrava até o outro lado da página. Como Pagés em sua citação de Labadens, verificamos em nosso processo como “[...] há evidentemente um primeiro nível de sedução, de ordem puramente estética. [...] O poder do traço. Uma escrita que fala ou não fala com você. Organizar um manuscrito prolonga esse sentimento muito particular de atração"; 96 com efeito: "O corpo do escritor fica marcado na escrita". ${ }^{97}$

\footnotetext{
${ }^{94}$ PAGÈS, A. A materialidade epistolar. O que nos dizem os manuscritos autógrafos. Revista do Instituto de Estudos Brasileiros, n. 67, p. 106-123, 31 ago. 2017 p. 108.

95 PAGÈS, A. Op. cit, p. 110.

${ }^{96}$ LABADENS, François. Cet obscur objet du désir. Propos d'un amateur d'autographes. [Este obscuro objeto do desejo. Entrevista com um amante de manuscritos autógrafos.] In L'entreprise et sa mémoire. Mélanges en l'honneur de Maurice Hamon. Organização de Didier Bondue. Paris: Presses Universitaires de Paris-Sorbonne, 2012, p. 236. Apud PAGĖS, A. A materialidade epistolar. O que nos dizem os manuscritos autógrafos. Revista do Instituto de Estudos Brasileiros, n. 67, p. 106-123, 31 ago. 2017 p. 110.

${ }^{97}$ In PAGÈS, A. Op. cit., p. 111.
} 
Sobre o espaço da escritura, Alan Pagés comenta que "[...] uma carta é um quadro e, em uma página, tem o poder de entregar o conteúdo total da mensagem, segundo uma disposição gráfica que lhe é própria." ${ }^{98}$ As cartas de Ungaretti a Bruna começam deixando uma ampla margem, o texto principal sempre centralizado, as linhas um pouco tortas e as bordas, no final, eram preenchidas com várias observações, por vezes numeradas “ 1 , 2, 3...”, ou indicadas com asterisco “*”. Fizemos um mapeamento da distribuição do texto na página: em alguns momentos, o maior desafio era entender de fato a ordem de alguns parágrafos, pois pareciam migrar às laterais. Os textos escritos nas bordas estão apresentados por uma marcação em conjunto de parênteses quadradas “[ ]", com a indicação em grifo de que o texto está contido na primeira, segunda ou seguintes páginas da carta. As cartas estão quase sempre datadas, indicando também o local onde foram escritas; em algumas ocasiões, o poeta fez uso de papel timbrado, ou próprio, ou do hotel em que se encontrava. Todos esses elementos foram considerados, anotados e permanecem no próprio corpo da carta, não em notas. Nossas notas foram distribuídas tanto para esclarecer dados biográficos das pessoas citadas como para demarcar questões pertinentes ao trabalho e à dificuldade da tradução das mesmas. Resta sempre relembrar o que Pagés resume como os dois objetivos contraditórios na edição e organização de cartas:

A edição de uma correspondência é tensionada por dois objetivos contraditórios: por um lado, o dever intelectual, que consiste em oferecer ao público um texto legível, uniformizado, livre de eventuais imperfeições; por outro, a necessidade de conservar, tanto quanto possível, a mensagem contida nos manuscritos autógrafos. Quando o editor dispõe do direito de reprodução dos documentos originais, a maneira de resolver tal contradição passa pela reprodução de fac-símiles, ou pela escolha de uma edição eletrônica, oferecendo a visualização tanto do texto editado quanto da imagem do manuscrito. ${ }^{99}$

Inserimos aqui, para apreciação, a fotografia da primeira página de uma carta escrita em Paris no dia 23 de novembro de 1966. No primeiro contato que fizemos com a editora Mondadori, enviamos algumas fotos em alta resolução juntamento com a transcrição que fizemos, para que a editora pudesse se certificar da autenticidade das cartas. A caligrafia do poeta é bastante clara, em alguns momentos aumenta o tamanho da própria letra, especialmente no final de cada carta, porém, em contraponto, há numerosas intervenções e correções nas próprias.

\footnotetext{
98 Ibid. Op. cit, p. 111.

${ }^{99}$ Ibid. Op. cit, p. 122.
} 


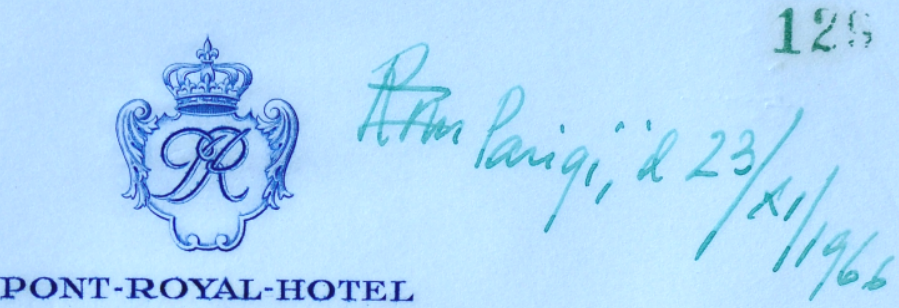

7. Rue Montalembert_PARIS

TÉL. $548.42-50$

TELEX. 23976. POSTE 306

Anima mia, oggi ero in uno stats d'siquie.

tudine folle. Occondo i mini conts,

le The letions avubles dovet esere

qui ini, i, tuk' al pris mele giomats.

Drasena ua gia'tandi, wo tomath

dall min galua. cayptaro degl'

Amia du Joresano poranzan cons na,

ed uns dovera utilizzan la comversa-

zinu mostra à bâtm rompus fur

Un' in tevista Jue Marda. The "

vinuto fuosi un' vituputazima tmi.

tile d'una lncidità che contiusu

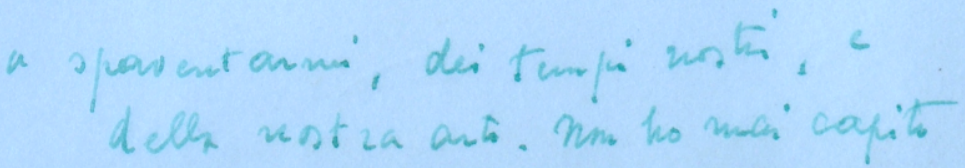


Ungaretti se mostra, mais uma vez, o poeta das variações - mesmo o texto epistolar deve sempre ser elaborado e corrigido. Num primeiro momento, acrescentamos as palavras que se encontravam fora da linha escrita com os sinais “ $<>$ ” para facilitar nossa transcrição; durante o processo de revisão da transcrição, esse sinal foi apagado para facilitar a leitura, pois as cartas já se encontravam bastante rasuradas - mantivemos prevalentemente no corpo do texto todas essas variações e rasuras. No começo do trabalho de escrita dessa tese, e até o momento do nosso exame de qualificação, adotamos, em nossa tradução, uma limpeza desses sinais de variações. Escolhemos, num primeiro momento, eliminar esses elementos gráficos que agregavam certa dificuldade à leitura para privilegiar uma aproximação às cartas que deixasse para trás a sua materialidade. Esse critério foi revisto após a qualificação, sobretudo a partir da leitura de Pagés e do encontro com Silvia Zoppi Garampi (vide abaixo). Com o avanço da pesquisa, se fez presente a necessidade de manter todas as variações também no texto traduzido. Esta mudança nos custou bastante tempo e atenção, pois tivemos que enxertar nossas traduções com as variações, "provocar" erros e encontrar soluções para que os erros pudessem funcionar com alguma correspondência ao original. Isso porque observamos o quão fundamental seria apresentar ao público leitor brasileiro toda a qualidade ungarettiana das variações, da perlaboração do texto, suas hesitações, a reescrita. Nos foi particularmente importante o encontro, mencionado acima, com Silvia Zoppi Garampi, durante um congresso internacional de italianistas ocorrido em Reykjavík em junho de 2018, ${ }^{100}$ e a leitura de seu trabalho sobre as variações do poeta nas cartas endereçadas a Leone Piccioni, ${ }^{101}$ em especial o poema "Stella", dedicado a Bruna Bianco, e presente, em diversas versões, também neste apanhado de cartas. Foram mantidas as rasuras em palavras que não se repetem, exceto na trascrição de poemas, e as que foram apagadas e surgiram novamente iguais foram descartadas em sua repetição. $\mathrm{Na}$ transcrição, foram mantidos os nomes citados com eventuais erros de grafia, "Oswaldo" ou "Osvaldo" em vez de "Oswald", "D’Orazio" e às vezes o correto "Dorazio", ou "Ginzberg” por "Ginsberg”. Os pronomes surgem em todo o conjunto às vezes com maiúscola, às vezes com minúscula, e dessa forma foram mantidos. A pontuação adotada por Ungaretti é peculiar, pois ele usa muitos apostos, e a leitura provoca uma sensação de estranheza,

\footnotetext{
100 Sponde, confini, trincee: l'Italia nell'Europa post-1918. Convegno Internazionale organizado pelos departamentos de estudos italianos da Universidade da Islândia e da Universidade de Varsóvia. Reykjavík, 7-8 jun. 2018 (http://www.iksi.uw.edu.pl/documents/11738337/12295789/REYKJAVIK_PROGRAM.pdf, consultado em 17 de maio de 2019).

${ }^{101}$ GARAMPI, Silvia. Varianti d'autore negli epistolari: il caso Ungaretti. I cantieri dell'italianistica. Ricerca, didattica e organizzazione agli inizi del XXI secolo. Atti del XVII congresso dell'ADI - Associazione degli Italianisti (Roma Sapienza, 18-21 settembre 2013), a cura di B. Alfonzetti, G. Baldassarri e F. Tomasi, Roma, Adi editore, 2014 (http:/ /www.italianisti.it/Atti-di-Congresso?pg $=$ cms\&ext=p\&cms_codsec=14\&cms_codcms $=581$, consultado em 20 de junho de 2018).
} 
mesmo em italiano. Decidimos manter, na maior parte dos casos, esse mesmo tom. Em alguns momentos, optamos por algumas modificações - para hospedar o caráter próprio da outra língua, mantendo porém, como intenção, a preservação de alguma estranheza no texto, alguma dificuldade de percorrer o texto livremente. Todos os registros de data foram mantidos, tanto na transcrição quanto na tradução, incluindo as variações do autor, ora indicando o mês por extenso, ora em números romanos, ora com pontos, ora com vírgulas. Onde ocorreram erros de registro da data, os mesmos foram corrigidos em nota da tradutora, indicando a data de envio postal contida no envelope. Também com colchetes "[]" e listas em grifo, indicamos em quais cartas o poeta anexou recortes de jornais, fotos e cartões postais. Mantivemos a variação também na transcrição da assinatura do poeta, ora "Unga", ora "Unga"” ou, ainda, "Ungà".

Em nosso trabalho de transcrição das cartas, nos guiamos primeiramente pelo estudo e leitura de outras obras epistolares publicadas nos últimos anos na Itália ${ }^{102}$ e, num segundo momento, nos amparamos em algumas publicações reunidas e específicas sobre o tema, como o dossiê "Artífices da correspondência" resa ${ }^{104}$, intitulada "Sobrescrito: cartas", como citamos anteriormente. A escolha por manter os traços, as revisões e as correções também em nossa tradução refletem uma tentativa de olhar para o material de arquivo, neste caso espistolar, através da lente de análise que nos apresentou Alan Pagés, ${ }^{105}$ pois o que ocorre é sempre um apagamento da materialidade do manuscrito, da materialidade das cartas:

Embora indiquem com precisão a origem do corpus a que se referem, a maioria das edições de correspondência apagam, no texto impresso que produzem, a materialidade do manuscrito autógrafo. É absolutamente normal. As edições têm como objetivo transcrever um manuscrito, transformar em obra coerente o que só existia, orginalmente, sob a forma de folhas dispersas. No entanto, todos aqueles que se dedicaram ao trabalho de edição sabem que uma perda considerável resulta do efeito de neutralização provocado pela forma impressa. O que se perde é o próprio aspecto do manuscrito, o poder de sedução que possuem uma escrita e folhas que exalam cheiro de um arquivo antigo que se preservou do desaparecimento graças aos cuidados de uma conservação escrupulosa ou, ainda, graças ao acaso de alguma milagrosa transmissão $0^{106}$.

\footnotetext{
102 Consultamos as cartas de Pirandello e Marta Abba, as de Montale e Clizia e cartas trocadas entre Ingeborg Bachmann e Paul Celan, a saber: Pirandello, Luigi. Lettere a Marta Abba. A cura di Benito Ortolani. Mondadori: Milano, 2013, col. "I Meridiani”. BACHMANN, Ingeborg. CELAN, Paul. Troviamo le parole. Lettere 1948-1973. Roma: Nottetempo, 2010. MONTALE, Eugenio. Lettere a Clizia. Milano: Arnoldo Mondadori, 2009.

103 MORAES, M.A.; NEVES, R.J. Apresentação do Dossiê Artífices da correspondência. Revista do Instituto de Estudos Brasileiros, n. 67, p. 103-105, 31 ago. 2017.

${ }^{104}$ EDITOR, O. Sobrescrito. Teresa, n. 8-9, p. xi-xi, 18 dez. 2008.

105 PAGÈS, A. A materialidade epistolar. O que nos dizem os manuscritos autógrafos. Revista do Instituto de Estudos Brasileiros, n. 67, p. 106-123, 31 ago. 2017.

106 Ibid.
} 
Apresentamos aqui mais uma exemplo da escrita nômade de Ungaretti, não somente em seu gênero - como observamos ao ler Brigitte Diaz — mas literalmente em trânsito pela página, como demonstra a última página da mesma carta que apresentamos logo acima, datada de novembro de 1966:

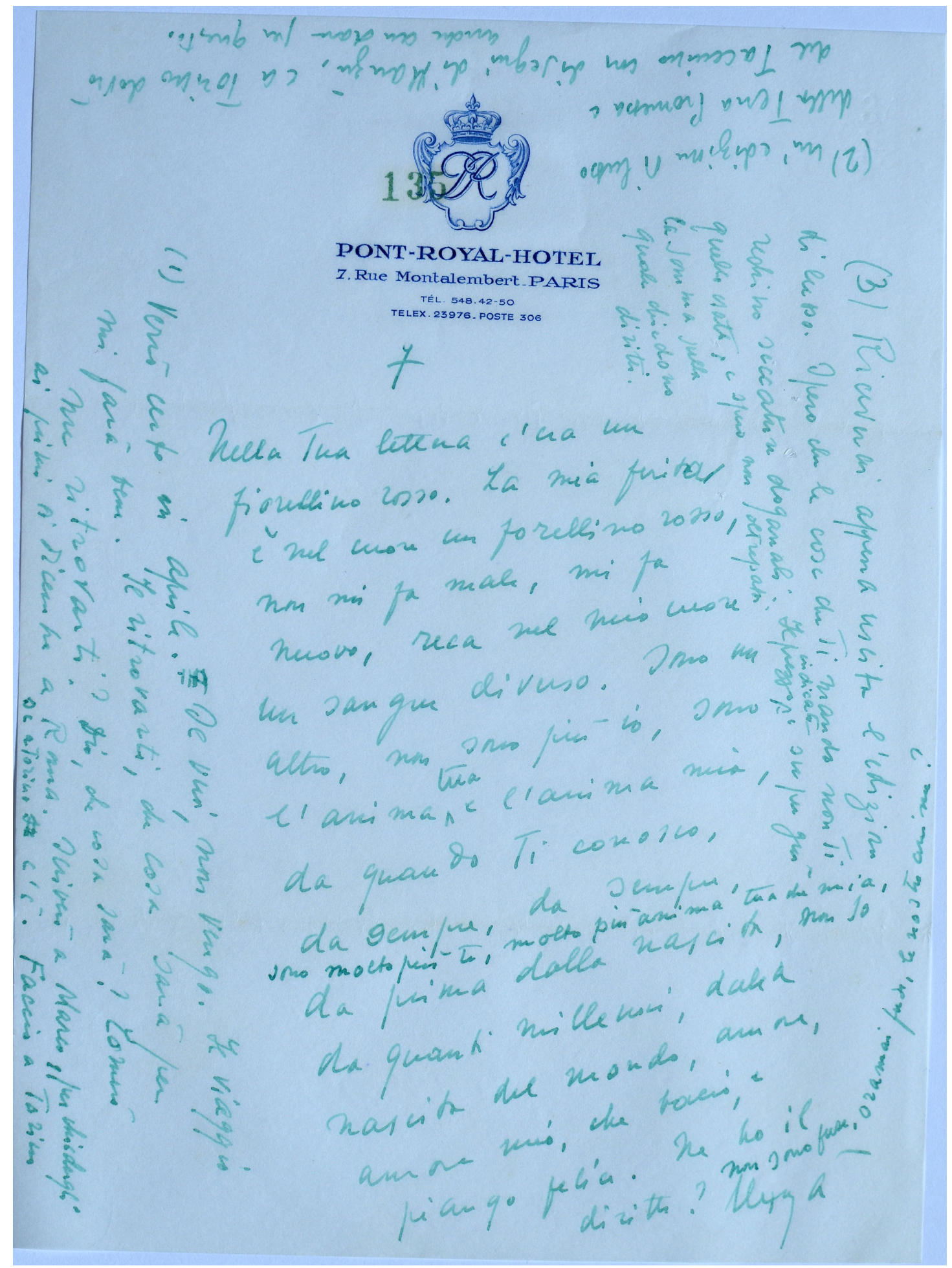


Por cinquenta anos, as cartas de Ungaretti estiveram guardadas, em perfeito estado, num baú, primeiramente no escritório de Bruna Bianco, depois num cômodo em sua casa. Foram mantidas, em sua vasta maioria, dentro dos respectivos envelopes, abertas — segundo a receptora — uma só vez, ou seja, quando as leu pela primeira vez, somente no momento em que as recebeu. Ela relata ter relido somente algumas, antes do nosso trabalho de transcrição, quando nos anos de 1990 tentou adiantar este processo com a ajuda da esposa de um executivo da Pirelli, por indicação de Pietro Maria Bardi. Houve um intenso cuidado em preservar as missivas, cuidado esse bem sucedido, talvez por algum acaso milagroso, pois não foram expostas nesse tempo todo a quaisquer intempéries fora do controle de um sujeito, simplesmente por estarem numa residência ou num escritório particular. Não houve incêndios nem enchentes que colocassem em risco a existência física daquelas cartas. Hoje, após nosso esforço em transcrevê-las e intermediar o diálogo com a editora Mondadori, as cartas podem ser consultadas na Fundação Mondadori em Milão. Um pesquisador pode tropeçar quase por um acaso num arquivo de cartas, ainda que estivesse à procura há muito tempo, resta o encanto deste...

[...] objeto preciosíssimo, a carta autógrafa, cujo formato, aparência gráfica e a própria fragilidade provocam uma emoção imensa naqueles que a contemplam ou a seguram nas mãos. Todas as bibliotecas conservam coleções que possuem múltiplos tesouros. Seria uma lástima permitir que os arquivos abertos da internet nos afastassem, hoje, pela facilidade de consulta, desses inúmeros arquivos que escapam à digitalização e obrigam o pesquisador a se deslocar, mas que lhe oferecem o privilégio de ter acesso a documentos raros e totalmente desconhecidos ${ }^{107}$.

Ou, como apontou Walnice Nogueira Galvão: "Há um estilo epistolar, em que as pessoas não brincam quando estão escrevendo cartas, porque aquilo vai ficar documentado, pode ser lido por terceiros $[\ldots]^{\prime 108}$

\subsection{RECORTE}

A fortuna literária e crítica presente nas cartas endereçadas a Bruna, assim como a poética da prosa de Ungaretti, os poemas escritos e traduzidos nos últimos anos da sua vida, as revisões dos mesmos, as revisões dos poemas de Bruna, podem apontar para diversos caminhos interpretativos e recortes. Seria impossível abordar todas essas possibilidades neste trabalho, ainda que fosse certamente tentador debruçar-se sobre todo o material tão rico e

107 Ibid. Op. cit., p. 122.

108 GALVÃO, Walnice Nogueira. A margem da carta. Teresa, n. 8-9, p. 14-29, 18 dez. 2008, p. 17. 
abarcar, num estudo crítico, de uma só vez, todo o seu conteúdo. No entanto, a sensação de nos perdermos num labirinto quase borgeano de hipertextos e referências fez com que tomássemos uma decisão diferente, ou seja, restringir o campo de estudo e ação, propor um recorte - uma cartografia para navegar as cartas e segui-la com atenção e maior profundidade.

Privilegiamos, cronologicamente, a seleção e tradução de cartas do primeiro período da relação entre Ungaretti e Bruna, ou seja, de setembro de 1966 a abril de 1967. Neste período, alguns dos temas centrais, que se repetem ao longo dos anos, surgem pela primeira vez e com maior vigor. É também nos primeiros meses que Ungaretti retoma a sua escrita de poemas, fazendo-o com a intenção de endereçá-los à amada e, por esse motivo, recorre a outros poemas e poetas, como inspiração e pretexto, para "estar com sua amada". Suas traduções se modificam em novas versões apresentadas quase cotidianamente e, assim, os poemas traduz̨idos se tornam autorais. São esses poemas que irão compor o volume Dialogo, com respostas de Bruna aos poemas de Ungaretti. No capítulo 3, iremos nos deter nessas versões. No capítulo 4, privilegiamos ressaltar temas bem presentes em todo o compêndio de cartas, mas que surgem com vigor sobretudo nos meses iniciais, ou seja, quando Ungaretti e Bruna começam a se conhecer. As questões que privilegiamos abordar foram: a perlaboração do poema e questões ligadas à crítica literária; dentro dessa divisão, apontamos o que diz respeito à língua italiana e à confusão entre línguas, a tradução e a relação de Ungaretti com seus tradutores e o Barroco. Num segundo momento do capítulo 4, decidimos aproximar as citações de Ungaretti sobre os artistas plásticos da sua escrita a respeito deles — tanto os seus contemporâneos, como outros artistas que fazem parte de suas reflexões em seus ensaios, ou atravessaram, em algum momento, a sua vivência biográfica. Começamos por retomar a questão da escuta, como já havíamos apontado no capítulo 1, como algo fundamental para a escrita dessas cartas e, então, descrevemos o caráter europeu da obra e das relações de Ungaretti, passando por Picasso, Vermeer, Cézanne, De Chirico, Modigliani, Savinio e outros artistas com quem o poeta colaborou, como Cagli, Burri e Dorazio. Enfim, também traçamos alguns paralelos e relações com as observações sobre as artes, os artistas e intelectuais brasileiros com quem Ungaretti não apenas conviveu nos anos em que morou em São Paulo, mas com os quais manteve-se em contato e encontrou-se também nos anos em que retornou ao Brasil para encontrar Bruna. Mantivemos também as cartas enviadas de Israel, por conter um profundo lirismo e relação com o texto bíblico, assim com algumas cartas de Londres - Paris, por sua vez, é a cidadepessoa sempre presente nas cartas de Ungaretti. Não pudemos examinar essas cartas com 
a mesma profundidade que as demais, ainda que constem aqui selecionadas, traduzidas e anotadas. A riqueza contida nessas cartas é tamanha que uma pesquisadora se vê obrigada, em algum momento, a parar e tentar costurar os caminhos abertos. Neste sentido, uma tese de doutorado é apenas o começo de um estudo profundo, pois, mesmo apresentando algumas vertentes de leitura e sendo estas analisadas com certa profundidade, permance a possibilidade de se continuar o trabalho. Tentamos oferecer aqui uma primeira cartografia para se navegar este arquivo, também com a esperança de que outras pesquisas apresentem outros caminhos.

Para além da análise do trabalho de tradução e criação exercido por Ungaretti nessas cartas de amor, apresentamos nossa tradução do recorte apontado. Seguindo o binômio conceitual de Berman — ação e reflexão — ${ }^{109}$ no capítulo 4, observaremos com maior atenção de que forma isso entra em relação com o discurso de Ungaretti e com o nosso esforço em traduzir as cartas. Houve também um outro questionamento enquanto traduzíamos: o que poderia, dessa correspondência, interessar ao público brasileiro? Em razão disso, privilgiamos um recorte que realce os afetos brasileiros do poeta, mas também onde o espaço dado à relação com as artes plásticas e o Barroco se mostra central. Os artistas citados e examinados por Ungaretti são centrais para toda a história da arte, e oferecer essa nova perspectiva pode ser interessante não apenas para os estudiosos do poeta nascido em Alexandria, mas também para abrir outras e novas possibilidades de leitura. Um recorte maior do que aquele que apresentamos aqui poderia ser adequado para o mercado editorial brasileiro. Ao nos determos com mais profundidade nas questões levantadas nessas cartas, a forma em que elas se apresentam e estão em relação com a sua obra, restringimos nossa atenção aos primeiros meses de relação entre Ungaretti e Bruna. A partir do nosso estudo, porém, seria interessante oferecer, caso exista uma demanda e um interesse nas cartas, um numero maior de traduções, abarcando também — com mais cartas — os outros períodos de encontro e distância entre os dois amantes, até culminar na última carta recebida por Bruna, no dia 14 de abril de 1969.

\footnotetext{
109 BERMAN, Antoine. A tradução e a letra, ou, O albergue do longínquo. Traduzido por Marie-Hélène Catherine Torres, Mauri Furlan e Andréia Guerin. Rio de Janeiro: 7Letras/PGET, 2007.
} 
Nestes fragmentos de um discurso amoroso ${ }^{110}$ tecidos através das cartas, o outro é invocado e constantemente representado na tentativa compreender e reduzir a dupla ausência. Os limites ditados pela vida, o tempo curto dos encontros e diálogos, parece ser compensado pela quantidade de cartas escritas por parte de Ungaretti e pelo florescimento de poemas e prosas riquíssimos. Recordamos aqui, aquilo que aponta Roland Barthes:

O discurso amoroso é hoje de uma extrema solidão. Tal discurso talvez seja falado por milhares de sujeitos (quem pode saber?), mas não é sustentado por ninguém; é completamente relagado pelas linguagens existentes, ou ignorado, ou depreciado ou zombado por elas, cortado não apenas do poder, mas também de seus mecanismos [...]. Quando um discurso assim é lançado por sua própria força na deriva do inatual, deportado para fora de toda gregariedade, nada mais lhe resta além de ser o lugar, por exíguo que seja, de uma afirmação. ${ }^{111}$

A aproximação imaginada e imaginária é facilitada pelos poemas e traduções apresentadas de um ao outro, voltando à imagem que já havíamos evocado a Erasmo de Roterdã: duas ausências comunicantes. Todo o corpo do discurso e da voz são direcionados a esse Outro amoroso. Ungaretti, na sua Carta n. ${ }^{\circ}$ 10, datada de 6 de outubro de 1966, confessa a Bruna: "erano sei anni che non facevo più poesia"112 — "há seis anos eu já não fazia poesia" — e poucos dias antes, na Carta n. ${ }^{\circ}$ 6, datada de 28 de setembro, " $m$ 'è rinata nel cuore la poesia, l'ba fatta rinascere la gentileza d'una pura voce di poesia; ma ciò che è, è, e non c'è Mefistofele che lo sappia mutare” ${ }^{113}$ _ "renasceu-me no coração a poesia, o que a fez renascer foi a gentileza de uma pura voz de poesia; mas o que é, é, e não há Mefistófeles que o saiba mudar”. Barthes começa o seu capítulo "O ausente” com a seguinte definição de ausência: “[...] todo episódio de linguagem que encena a ausência do objeto amado - sejam quais forem sua causa e sua duração - e tende a transformar essa ausência em provação de abandono". ${ }^{114}$ Esta reflexão parece acompanhar o que chamaríamos de onda mais longa da troca epistolar — ou seja, o discurso amoroso que se oferece como um rio subterrâneo e caudaloso, capa freática, que acompanha todas as cartas e que em alguns momentos emerge à superfície apresentando outras questões - língua, tradução, artes, referências, luz, identidade. É esta a imagem que já citamos: as ausências comunicantes, e partir delas emergem, protagonistas,

\footnotetext{
${ }_{110}$ Nos referimos aqui a BARTHES, Roland. Fragmentos de um discurso amoroso. Traduzido por Maria Valeria Martinez de Aguiar. São Paulo: Martins Fontes, 2003.

111 BARTHES, Roland. Fragmentos de um discurso amoroso. Traduzido por Maria Valeria Martinez de Aguiar. São Paulo: Martins Fontes, 2003, p. XV.

112 Carta n. ${ }^{\circ} 10$, datada de 6 de outubro de 1966.

${ }_{113}$ Carta n. $^{\circ}$ 6, datada de 28 de setembro de 1966.

114 BARTHES, Roland. Fragmentos de um discurso amoroso. Traduzido por Maria Valeria Martinez de Aguiar. São Paulo: Martins Fontes, 2003, p. 35.
} 
as criações literárias, as ideias, os devaneios, as correções de poemas e a reflexão sobre língua e tradução.

Há um duplo movimento de aproximação e distância: por um lado, as traduções que, aos poucos, se transformam em poemas autônomos, representam a possibilidade de lidar com a condição da ausência; por outro, a distância é também o motor propulsor da criação. O discurso da solidão, neste caso, encontra sustentação de ambas as partes, remetendonos novamente a Barthes, quando diz:

Sustento ao infinito, para o ausente, o discurso de sua ausência; situação em suma inaudita; o outro está ausente como referente, presente como alocutário. Dessa distorção singular nasce uma espécie de presente insustentável: fico acuado entre dois tempos, o tempo da referência e o tempo da alocução: você partiu (do que estou me queixando), você está aqui (já que me dirijo a você). Conheço então o que é o presente, esse tempo difícil: um puro pedaço de angústia. ${ }^{115}$

É nesse presente que cada carta se escreve e se inscreve (na relação), nesse pedaço de angústia, cada uma autônoma, mas também relacionada à anterior e sucessiva, também repetida alguns meses mais tarde. Há uma linha sutil que separa o rascunho do desenho há sempre a marca da edição, talvez um dos elementos textuais mais interessantes e sedutores. Há o preparo do texto, mas há também a espontaneidade de quem responde à carta recebida, há cobranças e reclamações, algumas acusações — mas é também nesse contexto que surgem as traduções e os poemas: na seleção que apresentamos aqui, tentamos também oferecer uma amostra do ambiente que facilitou cada criação contida entre as linhas. Quando Ungaretti recorre à tradução para endereçar seu discurso amoroso a Bruna, esta explosão — gênese do livro Dialogo — é o momento de maior tensionamento e de manipulação da linguagem, pois "a linguagem nasce da ausência", 116 é ela o atarefamento que acontece neste vácuo, continuando na descrição de Barthes:

A ausência dura, preciso suportá-la. Vou portanto manipulá-la: transformar a distorção do tempo em vai e vem, produzir ritmo, abrir a cena da linguagem (a linguagem nasce da ausência: a criança fabrica um carretel, joga-o e apanha-o, mimando a partida e a volta da mãe: um paradigma foi criado). A ausência torna-se uma prática ativa, um atarefamento (que me impede de fazer qualquer outra coisa); cria-se uma ficção com múltiplos papéis (dúvidas, recriminações, desejos, melancolias). ${ }^{117}$

\footnotetext{
115 BARTHES, Roland. Fragmentos de um discurso amoroso. Traduzido por Maria Valeria Martinez de Aguiar. São Paulo: Martins Fontes, 2003, p. 38-39.

116 Ibid.

117 Barthes prossegue: "Essa encenação linguageira afasta a morte do outro: um momento brevíssimo, dizem, separa o tempo em que a criança ainda crê que a mãe está ausente e o tempo em que já a crê morta. Manipular a ausência é alongar esse momento, retardar tanto quanto possível o instante em que o outro poderia resvalar secamente da ausência pela morte." Ibid. Op. cit., p. 38-39.
} 
Antes de avançarmos na análise e leitura das cartas selecionadas, é prudente relembrar outras publicações e relações epistolares que Giuseppe Ungaretti manteve. Em 2013, foi publicado o volume de cartas de Giuseppe Ungaretti e Leone Piccioni, sob o título L'allegria è il mio elemento, ${ }^{118}$ com curadoria de Silvia Zoppi Garampi, trezentas cartas trocadas pelo poeta com pupilo e amigo Piccioni. Na Universidade de São Paulo, a colega Laura Ferreira traduziu e analisou um recorte deste volume em sua disertação de mestrado, privilegiando um retrato de Ungaretti e sua chiara fama, não somente o recebimento do título de doutor honoris causa por notório saber, mas explorando também as suas redes de relacionamentos — de alguma forma, a sua manipulação da fama. Trata-se de uma correspondência afetuosa, concernente, sobretudo, ao trabalho poético e editorial de Ungaretti. Também conhecidas são as trocas com Soffici, De Robertis, Papini, Paulhan, Prezzolini e Giuseppe Raimondi. ${ }^{119}$ Houve também outra correspondência amorosa de Ungaretti. Este arquivo ainda permanece inédito. Estas cartas foram escritas para Jone Graziani, ${ }^{120}$ uma jovem que Giuseppe Ungaretti conheceu logo após a morte de sua esposa Jeanne Dupoix, nos anos de 1950. Essa correspondência, que durou por mais tempo — estima-se que por sete anos — contém um numero inferior de cartas, a saber, trezentas e setenta e seis, das quais trezentos e vinte e sete conservadas e quarenta e nova desaparecidas, talvez destruídas pela destinatário devido ao conteúdo, segundo ela, obsceno. O que restou de maior valor literário da correspondência com Graziani foi o poema "Canto a due você", o penúltimo do livro Taccuino del Vecchio. ${ }^{121}$

A comunicação entre Ungaretti e Bianco possui uma característica de urgência, talvez pela distância física, ou pela idade mais avançada de Ungaretti, talvez pelo pouco mais

\footnotetext{
118 UNGARETTI, Giuseppe. L’allegria è il mio elemento. Org. Silvia Zoppi Garampi. Milano: Mondadori, 2013. 119 UNGARETTI, Giuseppe. Lettere a Soffici (1917-1930). A cura di P. Montefoschi. Firenze: Sansoni, 1981. UNGARETTI, Giuseppe. De Robertis, Giuseppe. Carteggio (1931-1962). A cura di D. De Robertis. Milano: Il Saggiatore, 1984. UNGARETTI, Giuseppe. Lettere a Giovanni Papini (1915-1948). A cura di M. A. Terzoli. Milano: Mondadori, 1988. UNGARETTI, Giuseppe. PAULHAN, Jean. Correspondance (1921-1968). Éd. par J. Paulhan, L. Rebay et J.-C. Vegliante. Paris: Gallimard, 1989. UNGARETTI, Giuseppe. Lettere a Giuseppe Prezzolini (1911-1969). A cura di M.A. Terzoli. Roma: Edizioni di Storia e Letteratura, 2000. UNGARETTI, Giuseppe. Lettere a Giuseppe Raimondi (1918-1966). A cura di E. Conti. Bologna: Patron, 2004.

${ }^{120}$ Dentre essas cartas, há o que são consideradas as "cartas francesas": “[...] analoghe considerazioni possono farsi in merito alle 75 lettere francesi di Ungaretti a Jone Graziani conservate a Parigi nella Bibliothèque Littéraire Jacques Doucet unitamente ad altre 253 in italiano. In una lettera in data 7 gennaio 1970, Jone Graziani mi informava di essere in possesso di 376 lettere e 41 telegrammi del poeta e che con il di lui consenso, ma a condizione ne fosse vietata la pubblicazione prima della sua morte, avrebbe desiderato vendere l'intero carteggo alla Columbia University, dove Ungaretti come è noto era stato Visiting Professor nel 1964. Più tardi appresi da lei che aveva invece deciso di cederlo alla Doucet dopo averne distrutto varie missive — suppongo le 49 mancanti al conteggio — a suo dire "decisamente oscene". Volle donare gli originali dei 41 telegrammi più, in facsimilie, un fascicolo di lettere francesi e italiane e cinque manoscritti autografi della poesia che Ungaretti aveva composto per lei e le aveva dedicato — quattro di essi esclusi dal lascito alla Doucet", como escreve Luciano Rebay em seu ensaio (REBAY, Luciano. Ungaretti lettere a Jone, Prima poesia per Jone, Canto a due voci per Jone. Revue des Études Italiennes. Nouvelle série. Tome 49. No. 1-2, Gen.Giu. 2003 p. 113.

121 REBAY, Luciano. Ungaretti: Lettere a Jone, Prima poesia per Jone, Canto a due voci per Jone. Forum Italicum, Anno 2004, n. 1, p. 45-65.
} 
de meio século de idade que separava os dois. Com tal urgência, coexiste uma profusa discussão poético-literária, traduções e correções e um nítido recomeço, para Ungaretti, do fazer poético, aliado ao começo de Bruna, à urgência se servir como o mestre num laboratório de versos, corrigindo suas tentativas, enviando-lhe os textos com suas sugestões e demandando, sempre, um retorno.

Ungaretti foi um correspondente prolixo, como observamos pelos volumes reunidos de correspondências trocadas. Mais uma vez, retomamos a questão do pacto que se faz ao ler uma carta, já que parece não ser possível dissociar dos endereçamentos epistolares a própria ideia de ficção e encenação. Silviano Santiago ${ }^{122}$ aponta que “[...] o leitor precisa tomar a mesma atitude reflexiva que possui ao ler um texto literário quando se encontra em contato com cartas entre escritores, pois 'a carta tem algo de diário íntimo e [...] de prosa de ficção" ${ }^{123}$. Ou, como aponta Julio Castañon Guimarães, ${ }^{124}$ “[...] a correspondência, ao contrário do que se pensa, nem sempre é o lugar de um compromisso sincero: trata-se de uma encenação". ${ }^{125}$ Nos próximos dois capítulos, tentamos observar como essas manifestações que entrelaçam ficção e autobiografia — assim como o jogo de encenação que ocorre dentro do espaço autobiografico - se manifesta. No capítulo 3, olhamos com atenção para a tradução de poemas, nos primeiros meses de correspondência, passando do gesto tradutório à recriação e, enfim, à edição e lapidação de um poema autoral — uma forma de encenação literária. No capítulo 4, propomos uma cartografia para a navegação das cartas, explorando alguns dos temas centrais — na obra e vida do poema — e como eles surgem e ressurgem nas cartas endereçadas à amada. Além do lirismo da prosa poética que caracteriza o estilo do epistolário de Ungaretti dedicado a Bruna Bianco, há incursões a respeito de teoria e crítica literária, referências, por vezes explícitas, por vezes veladas, assim como inúmeras observações sobre pintores contemporâneos, da modernidade e da antiguidade, poetas e escritores contemporâneos ao autor, poemas e traduções apresentados em diversas versões e relatos de suas viagens: Telavive, Paris, Urbino e Londres, entre outras. Entre as cartas, surge também a composição de um poema, ou texto, que deverá ser musicado, deverá se transformar em canção: Ungaretti escreve um poema para que Marco Bianco, irmão de Bruna, componha

\footnotetext{
122 Davi Pessoa, em sua dissertação de mestrado, analisa a tradução de Edoardo Bizzarri para a língua italiana do romance Grande Sertão: Veredas de Guimarães Rosa, há neste trabalho uma análise extensiva e bastante profunda do epistolário de Bizzarri e Rosa, assim como a análise de algumas cartas trocadas entre Rosa e seu tradutor para língua alemã Meyer-Clason. Além da dissertação — que pode ser consultada aqui: http://bdtd.ibict.br/vufind/Record/UFSC_478f8cf87aca181962f17ed54866e73d (consultado em 20 de junho de 2015) — indico: PESSOA, Davi.

Terceira margem: testemunha, tradução. Florianópolis: Editora da Casa, 2008.

123 PESSOA, Davi. Op. cit., p. 33 e SANTIAGO. Op. cit., p. 76.

${ }_{4}^{4}$ Autores citados por Davi Pessoa: GUIMARÃES, Julio Castañon. Contrapontos: notas sobre correspondência no modernismo. Rio de Janeiro: Fundação Casa de Rui Barbosa, 2004.

SANTIAGO, Silviano. Suas cartas, nossas cartas. In Ora (direis) puxar conversa! Belo Horizonte: Ed. UFMG, 2006.

125 PESSOA, Davi. Op. cit., p. 33 e Castañon. Op. cit., p. 9.
} 
uma música. Acaba tecendo promessas de apresentá-lo aos amigos da Rai, a Vinícius, que está morando na Itália, a Chico Buarque. Marco Bianco estudava engenharia em Turim e, mais de uma vez, encontrou o poeta e o acompanhou por suas viagens e leituras na Itália.

São trezentos e setenta e cinto cartas e dois telegramas, no total, o material transcrito, além de inúmeros livros, artigos, presentes e fotografias que compõem a materialidade desta troca - seu corpo. Em nosso recorte, privilegiamos o começo da relação entre Ungaretti e Bruna, muitas cartas traduzidas sequencialmente, ainda que existam, enfim, cartas de outros períodos, também selecionadas e traduzidas. Tentamos privilegiar o Ungaretti tradutor-criador: Ungà tradutor por amor. Demos maior atenção aos poemas traduzidos durante o primeiro ciclo romano, ou seja, as cartas que foram trocadas entre setembro e outubro de 1966, os primeiros dois meses de relacionamento. Entretecido, juntamente com o diálogo amoroso, há a recriação de poemas, revisões e comentários a partir de autores árabes e de James Joyce. Há também, curiosamente, um poema transcriado por Ungaretti a partir do estilo da sua amada Bruna Bianco. 



\title{
O PORTO SEPULTO
}

\section{DA POÉTICA TRADUTÓRIA DE UNGARETTI}

\author{
O porto sepulto é o que de secreto permanece \\ em nós indecifrável \\ Giuseppe Ungaretti, Vita d'un nomo
}

3.1 UNGARETTI TRADUTOR

3.2 A PRESENÇA E O PAPEL DA TRADUÇÃO

NAS CARTAS A BRUNA BIANCO 



\subsection{UNGARETTI TRADUTOR}

A tradução não é só um laboratório essencial para a escrita de Giuseppe Ungaretti, mas também uma atividade que não se pode separar da criação. Carlo Ossola, em seu texto de apresentação ao volume da coleção "Meridiani”" de Traduz̧ioni Poetiche, afirma:

Per comprendere la poesia di Ungaretti, occorrerebbe leggere prima questo "Meridiano" di traduzioni e poi Tutte le poesie, perché qui, nella convocazione dei classici della poesia europea: Shakespeare e Góngora, Racine e Blake e Mallarmé, non meno che nella solidaeirtà con la più altra poesia contemporanea; da Saint-John Perse a Michaux, da Murilo Mendes a Ponge, e infine nel dialogo di "affinità elettive" con i poeti che l'hanno tradotto nelle loro lingue: Pierre Jean Jouve, Philippe Jaccottet e ancora Ponge, come Ingeborg Bachmann e Paul Celan; qui risiede il ruolo essenziale che Ungaretti svogle nella poesia del Novecento italiano $[\ldots] \cdot{ }^{126}$

Para entender a poesia de Ungaretti, ocorre antes ler suas traduções, pois é na relação com os clássicos europeus, ou na tradução de seus contemporâneos — diz Ossola — bem como no diálogo com seus companheiros e tradutores, que observamos o papel fundamental que Ungaretti ocupa na poesia italiana do século XX. E não apenas no panorama poético italiano, diríamos, mas em toda poesia ocidental. É preciso recordar as traduções brasileiras de Ungaretti, suas viagens a tantos outros cantos do mundo, do Japão à Suécia, da Argentina a Israel - recordar seu vínculo com diversos artistas, seu estado de diálogo constante, tanto em textos escritos para catálogos como em reflexões mais extensas para editoras. Fruto de numerosos enxertos, como ele próprio se definiu, Ungaretti é dono de uma poética impar, rica e aberta ao outro. Neste capítulo, examinamos com maior atenção o processo de tradução e criação que surge nos primeiros meses da relação epistolar com Bruna Bianco, quando Ungaretti volta à escrita e faz uso da tradução como motor propulsor para a sua própria criação poética.

Para Ungaretti, renovar a linguagem é uma atividade que entrelaça a tradução à criação poética: traduzir, para o poeta, seria "[...] la risposta più alta che possiamo dare all’invecchiamento della língua", ${ }^{127}$ a resposta mais alta que se pode dar ao envelhecimento da língua-linguagem. O trabalho de tradução abarca um "[...] um estado quase perene de inquietação, que também traz à luz a condição do estar sempre num espaço híbrido, no

126 UNGARETTTI, Giuseppe. Vita d'un uomo. Traduzioni Poetiche. Milão: Mondadori, 2010, p. XI-XII, col. "Meridiani".

127 Ibid. 
qual as fronteiras culturais se misturam", ${ }^{128}$ como afirma Patrícia Peterle. Se, por um lado, Ungaretti pode parecer um "sujeito desgarrado", ${ }^{129}$ por outro, é profundamente arraigado nos territórios multiplos que compõem suas pátrias: Egito, França, Itália e Brasil, que formam "esse complexo conjunto pátrio do habitar". ${ }^{130}$

A primeira tradução publicada de Giuseppe Ungaretti é a de um conto de Edgar Allan Poe, "Silence", do livro Romances of death, ou, em sua tradução, Silenæiio, publicada em 1910 no jornal Il Messaggero Egiziano. Não por acaso, o jovem Ungaretti escolhe Poe, o escritor admirado por Baudelaire e Mallarmé, mestres que o nosso poeta seguiu em seu período de formação. Ungaretti começa com o desejo e a ousadia de se colocar como tradutor daquele que foi traduzido por eles: Baudelaire, "um poeta maldito, marcado por Deus", e o outro, Mallarmé, tomado "pelo mistério da formação das palavras". ${ }^{131}$ Ungaretti traduz Edgar Allan Poe cinco anos antes da sua estreia como poeta, na revista Lacerba. Ao cotejar a tradução do texto de Poe com o original, parecem saltar da página versos (prontos) de Ungaretti, como um laboratório de experimentação e medida do próprio corpo com o corpo-texto de outro escritor.

Ossola analisa com minúcia ${ }^{132}$ como alguns dos temas presentes no primeiro livro do poeta já estavam contidos nas palavras que emergem dessa tradução: silêncio — na tradução de Poe: “[...] nel deserto illimitato [...] la parola scolpita: SILENZIO" ${ }^{133 ” ; ~ n a ~}$ poesia de Ungaretti: "Quando io trovo / in questo mio silenzio / uma parola / scavata è nella mia vita / come um abisso" 134 — ou desolação — na tradução de Poe: "[...] ma la luna irradiò uma luce di più rossa animazione: mi volsi, lessi: DESOLAZIONE"; na poesia do tradutor: "Da questa terraza di desolazione". ${ }^{135}$ O fato de a tradução incidir sobre sua criação é, portanto, uma constante, algo que encontra-se desde o início de seu trabalho como tradutor e poeta. Ungaretti escolhe sua filiação e coloca-se no mesmo fluxo, operando também como tradutor, seguindo as pegadas de Baudelaire e Mallarmé, e extraindo do seu exercício um artifício, uma apropriação da linguagem, uma refração do que é para o autor a via de renovação da mesma. Outra curiosidade é como, nessa tradução, Ungaretti introduz elementos que pertencem ao seu histórico biográfico, como observado por

\footnotetext{
128 PETERLE, Patricia. No limite da palavra. Percursos pela poesia italiana. Rio de Janeiro: 7Letras, 2015.

129 Expressão citada por Peterle apud Raul Antelo em Maria com Marcel. Duchamp nos trópicos. Belo Horizonte: Editora da UFMG, 2010.

130 PETERLE, Patricia. Op. cit.

131 Do ensaio “Per Mallarmé”. In UNGARETTI, Giuseppe. Vita d'um Uomo. Saggi e Interventi. Op. cit. p. 208-209, tradução nossa.

132 Introdução ao volume UNGARETTI, Giuseppe. Vita d'un uomo. Traduzioni Poetiche. Op. cit., p. XV-XXI.

133 UNGARETTI, Giuseppe. Vita d'un uomo. Traduzioni Poetiche. Milão: Mondadori, 2010, p. 12, col. "Meridiani”".

134 UNGARET'TI, Giuseppe. Vita d'un uomo. Tutte le poesie. Op. cit., p. 96.

135 UNGARETTI, Giuseppe. Vita d'un uomo. Tutte le poesie. Op. cit., p. 62.
} 
Ossola: "[...] egli traduce, con felice calco il morass di Poe, il marécage di Baudelaire, con 'maremma', unita — in Poe come nella sua vita — a 'deserto' e 'desolazione"'136 — é o ano de 1910, Ungaretti ainda não conhece a Maremma senão pela narrativa familiar, apesar de conhecer, sim, e muito bem, o deserto da sua terra natal. Movimentos de apropriação, recriação e transcriação surgem desde o começo da trajetória de Ungaretti, já com a tradução do conto de Edgard Allan Poe.

Ungaretti segue traduzindo, e reúne numa publicação de 1936, na revista Novissima, os seguintes nomes: Saint-John Perse, Blake, Góngora, Iessienin, Paulhan. Trata-se, em sua maioria, de textos já publicados anteriormente noutras periódicos. Conclui essa antologia com um conjunto cujo título é "Affrica", composto de textos traduzidos a partir do francês, com curadoria de Blaise Cendrars. ${ }^{137}$ Ao examinarmos as traduções presentes no diálogo com Bruna, há de se levar em consideração o tradutor do passado, ou seja, observar como a tradução também foi participando de sua escrita. $\mathrm{Na}$ aprsentação desse volume de traduções, o poeta-tradutor afirma não haver chegado àqueles poetas e poemas por acaso: ${ }^{138}$ decide traduzir Blake para reagir a uma paralização que sofria em relação aos "problemas de técnica", e prossegue, assertivo: "Na arte, o sentimento nunca saberá se separar da inteligência, e também a tradução, que, como todos sabem, é para um escritor que queira treinar sua mão, um exercício sem igual". ${ }^{139}$

O atravessamento biográfico está presente no trabalho de Ungaretti seja enquanto autor como quanto tradutor. Sua escolha de traduzir Saint-John Perse parece ser motivada pela história épica de um "estrangeiro", diz o poeta, "vinculado aos seus modos" e andarilho "por todas as estradas da terra"; ${ }^{140}$ há o deserto como espaço presente nesta poética, além da preponderância da força da natureza. Ungaretti procura os seus temas e os extrai dos trabalhos sobre os quais se debruça, sejam eles de tradução ou outra forma de diálogo,

\footnotetext{
136 UNGARETTI, Giuseppe. Vita d'un uomo. Traduzioni Poetiche. Op. cit., p. XVII.

${ }_{137}$ Sobre a relação Ungaretti com Blaise Cendrars, Oswald de Andrade e Haroldo de Campos, recomendamos consultar o artigo: WATAGHIN, Lucia. Ungaretti entre Oswald de Andrade, Blaise Cendrars, Haroldo de Campos: afinidades e assimetrias. Remate de Males. Campinas-SP, v. 37, n. 2, p. 971-984, jul./dez. 2017. É interessante notar como a questão da antologia de contos negros organizada por Cendrars chegou até Ungaretti já em 1919, e não houve notícia de uma edição italiana, até muito mais tarde, quando, numa carta a Bruna, o poeta comenta ter sido chamado para apresentar uma antologia análoga, já nos anos de 1960. Wataghin escreve: "Mas voltando à primeira Anthologie nègre, uma reação imediata à sua ideação (antes mesmo da publicação), no ambiente que nos interessa aqui, foi justamente a de Ungaretti. Naquele 'mês' (ou pouco menos de um mês) de 1919 em que preparava sua Anthologie, Cendrars teve tempo ainda de projetar, com Ungaretti (1988), uma nova antologia negra, em italiano, feita do material não utilizado na primeira. O projeto foi apresentado a Giovanni Papini, a quem Ungaretti pediu que encaminhasse a proposta para o editor Vallecchi, mas isso não foi realizado, e dele restou, na produção de Ungaretti, apenas a tradução de um dos textos da Anthologie de Cendrars ('La danse des animaux', que Ungaretti traduziu com o título 'Tam tam degli animali') (UNGARETTTI, 1936)" (p. 975). Já na carta datada de 14 de janeiro de 1967, Ungaretti afirma: "Il 9 devo presentare alla libreria paesi nuovi il libro della poesia d'oggi della gente nera curato dalla Societé Africaine de culture."

138 UNGARET'TI, Giuseppe. Vita d'un uomo. Traduzioni Poetiche. Op. cit., p. 19.

$139 \mathrm{Ibid}$, tradução nossa. Ainda segundo Ungaretti, as traduções de Blake aparecem anter na revista Tevere, sete anos antes dessa publicação.

140 Ibid.
} 
como, por exemplo, nos ensaios sobre artistas plásticos ou em textos escritos para esses catálogos, como veremos no capítulo seguinte. Assim como Ungaretti inicia sua participação no mundo literário com uma tradução de Poe — seguindo as pegadas dos seus mestres - ele continua traduzindo atento aos seus temas e a como esses autores são também recebidos e traduzidos pelo mundo. Destaca, na apresentação, do volume de 1936 da revista Novissima, que os mesmos poemas de Saint-John Perse surgiam em tradução russa, espanhola e inglesa, esta última assinada por T.S. Eliot, e, por fim, em alemão - cuja primeira tentativa foi de Rilke, completada por Berbar Groethuyesen. Noutras palavras, Ungaretti se insere no debate e no meio literário também traduzindo. Traduzir faz parte de sua pesquisa, do treino do verso, mas também é uma forma de estar no mundo num sentido mais amplo. Sobre a tradução de Góngora, falaremos mais adiante, no capítulo 4, anotando aqui, en passant, que ela reafirma a certeza da pesquisa contínua e obsessiva pelo Barroco. Sobre a tradução dos dois poemas de Iessienin, Ungaretti dizP “[...] queria traduzir $[. .$.$] para conhecer o motivo da relutância às massas rurais russas no primeiro regime$ soviético". ${ }^{141}$ Também admite que só pôde traduzir a partir da intervenção dos seus amigos Maria Miloslawsky e Franz Hellens. Sobre estas traduções é interessante consultar a leitura de Aurora Fornoni Bernardini no volume Daquela estrela à outra, ${ }^{142}$ na qual a autora observa atentamente, a partir das duas versões traduzidas por Ungaretti (em 1933 e 1936), o que permanece do orignal e o que é carregado como uma tradução literal. Bernardini também observa como o ritmo, nessa tradução, não é reportado ao italiano, e analisa a tradução de Ungaretti mostrando ao leitor uma tradução literal para o portugês. Há, enfim, traduções de seu grande amigo Jean Paulhan, citado inúmeras vezes nas cartas a Bruna, e alguns poemas da sua terra de infância e adolescência, “[...] para demostrar como em grande parte [...] neste volume" — diz o poeta — "está a minha saudade". ${ }^{143}$

Ungaretti desloca seu pensamento sobre a composição poética — elaborando-o de início num sentido mais concreto, ou seja, a intensificação do uso da própria língua a partir da experiência com liberdade de composição, e aqui se poderia acrescentar que é algo que nasce também a partir da experiência de tradução, ou seja roçar a liberdade que existe na língua do outro - para um patamar metafísico, no qual diz ser preciso devolver à memória sua medida de angústia. É neste sentido que Ossola afirma, em seu texto de 2009, que abre edição das traduções reunidas de Ungaretti, celebrando, naquela ocasião, os quarenta anos

141 UNGARETTI, Giuseppe. Vita d'un uomo. Traduzioni Poetiche. Op. cit., p. 21.

142 WATAGHIN, Lucia (org.). Daquela estrela à outra. Traduções de Haroldo de Campos e Aurora Fornoni Bernardini. São Paulo: Ateliê Editorial: 2004.

143 UNGARET'TI, Giuseppe. Vita d'un uomo. Traduzioni Poetiche. Op. cit., p. 21. 
da edição príncipe do volume: "Tradurre è innervare sulla patina d'uso di una lingua la ‘libertà’ dell'altrui comporre, 'restituire alla memoria la sua misura d'angoscia”'. ${ }^{44}$ Nas traduções presentes no diálogo com Bruna, há um deslocamento contínuo com vistas a explorar a liberdade de composição do outro. Isso fica patente já na escolha dos versos de Joyce e também dos poetas árabes: esta forma de partir de uma tradução e conjugar versos traduzidos — de um poema e de outro — num novo poema próprio. Ungaretti incentiva a escrita de Bruna, oferece correções e propõe mudanças, mas também escreve um poema para a amada usando a própria poética dela, incorporando os recursos da jovem iniciante como ponto de partida e inspiração. Também durante o trabalho de tradução dos versos de Vinícius de Moraes, esforço que cumpre em conjunto com Bruna, ele observa o estilo prolixo do amigo e traduz como se buscasse uma síntese entre a língua de partida e a possiblidade mais sintética de apresentação na língua de chegada. Por exemplo, na Carta n. ${ }^{\circ}$ 366, datada de 12 de fevereiro de 1969, Ungaretti escreve: "Deves ter recebido minhas traduções de Vinícius, ótimo poeta, mas quanta conversa para dizer o que para nós se diz em poucas palavras”, e continua: “[...] a síntese na arte é um privilégio europeu (e não de todos os países europeus) que ainda não atravessou o oceano, pelo menos o que banha os países do sul". Ungaretti toma, neste breve momento de escrita à amada, a poesia de Vinícius de Moraes como toda a poesia brasileira, ou toda a poesia escrita no Sul do mundo. É comum observarmos essa característica de Ungà em todo o conjunto epistolar: o movimento de fazer declarações por vezes inflamadas e radicais enquanto escreve à amada. Pelo comentário, Ungaretti parece ignorar completamente o manifesto da poesia concreta, ou sua própria experiência de tradução de Oswald de Andrade.

Ungaretti segue traduzindo Shakespeare, Góngora, Racine, Blake, Mallarmé e seus contemporâneos Saint-John Perse, Michaux, Murilo Mendes e Ponge. Também mantém um diálogo com seus tradutores e, a partir da sua vivência no Brasil, seleciona e traduz, sob o título de Pau Brasil, não apenas poemas de Oswald de Andrade, mas também mitos da criação indígenas (tupi, carajá e bororó) sob o título "Fábulas indígenas da gênese"145, além de José de Anchieta, Tomás António Gonzaga, Gonçalves Dias, Mário de Andrade, e, mais tarde, Drummond, Bandeira, Vinícius de Moraes e Augusto Frederico Schmidt. Em sua nota de abertura aos sonetos de Shakespeare, Ungaretti diz traduzir desde 1931 com constância, num “[...] extenuante empenho de renovação, problemas de ordem ténica

\footnotetext{
144 OSSOLA, Carlo. Ungaretti, Poeta. Venezia: Marsilio, 2016, p. 53.

145 Recomendamos duas leituras aqui: (1) WATAGHIN, Lucia. Um mito tupi traduzido por Giuseppe Ungaretti: 'Mai Pituna Oiuquau Ãna' ('Como a Noite Apareceu'). Revista USP. São Paulo, no 37: 168-173. Março/Maio, 1998. E (2) LANCIANI, Giulia (org.). Il Brasile di Ungaretti. Roma: Istituto Poligrafico e Zecca dello Stato, 2003.
} 
ou de simples inspiração". Segundo ele, essas indagações "[...] me levavam para resolvêlos ou conferir pelo menos a validade das pesquisas, a analizar ao vivo, como só pode ser feito traduzindo, certos aspectos de escritores de diferente índole e origem." 146 Ungà diz ter adentrado tantas em traduções diversas em busca de um poesia sonhada, ou seja, “[...] uma poesia em que o segredo da alma, não traída nem falseada pelos impulsos, se conciliasse com uma extrema sabedoria do discurso". ${ }^{147}$ O poeta abraça este exercício para fazer, dele também, uma forma de crítica, de reflexão sobre o próprio fazer da poesia — traduzir como uma expansão da compreensão sobre a escrita.

Nas traduções que apresentaremos no próximo capítulo, tentamos seguir esta mesma linhagem analítica proposta por Ungaretti. O poeta parece apontar para um movimento longo de memória no qual está contida a poesia em todo nosso tempo, sendo a tradução como que um gesto que se faz, mas que está também sempre para ser feito e repetido, como um devir. Observamos, neste sentido, alguma refração no pensamento da filósofa e filóloga francesa Barbara Cassin. ${ }^{148}$ Ungaretti diz: “[...] os velhos temas são de todos os tempos e, para dizer a verdade, da própria poesia popular”; e continua: “[...] mas, desde Petrarca, em toda Europa quer-se dizer que a poesia possui o movimento da memória e tende, para uma linha de testemunho autobiográfico"; e conclui: “[...] sem perder nada de sua variável concretude de época e lugar". ${ }^{149}$ Barbara Cassin, que se ocupou dos limites do traduzível e do não traduzível no seu Dicionário dos Intraduzíveis ${ }^{150}$, fez seu elogio à tradução, complicando o universal, ${ }^{151}$ relembrando-nos aqui o pensamento de Ungaretti sobre a expansão da própria língua através da passagem pela liberdade da linguagem do outro. Para Cassin, é somente através da tradução que chegamos a localizar o intraduzível como dimensão fundamental de uma língua. A autora, que também fertiliza seu pensamento com a psicanálise, traça uma analogia, pois é também é somente na relação com o outro que podemos nos dar conta do próprio sintoma. Ungaretti habita a língua do outro e usa sua relação com aquela para aprofundar a sua própria escrita — não apenas para resolver questões técnicas, como ele próprio diz, mas também solucionar questões de inspiração. $\mathrm{Na}$ alteridade, não só se percebe o que não se traduz, mas também o que resiste à

\footnotetext{
146 UNGARET'TI, Giuseppe. Vita d'un uomo. Traduzioni Poetiche. Op. cit., p. 131, tradução nossa. 147 Ibid. Tradução nossa.

148 CASSIN, Barbara. Après Babel, traduire. Actes Sud Beaux Arts Hors collection. Paris: Décembre 2016. (https://www.actes-sud.fr/catalogue/musees-collections-expositions/apres-babel-traduire, consultado em 14 de abril de 2019).

149 UNGARETTI, Giuseppe. Vita d'un uomo. Traduzioni Poetiche. Op. cit., p.131-132, tradução nossa.

${ }^{150}$ CASSIN, Barbara. Dictionary of Untranslatables. A Philosophical Lexicon. Traduzido ao inglês por Steven Rendall, Christian Hubert, Jeffrey Mehlman e Nathanael Stein. Princeton: Princeton University Press, 2014.

151 CASSIN, Barbara. Éloge de la traduction. Compliquer l'universel. Paris: Fayed, 2016.
} 
universalização. Desta forma, como Ungaretti, observa a poesia que carrega os velhos temas de todos os tempos, sem perder, porém, nada da variação dada pela época e lugar. Um universal distante como pano de fundo diante de tantas refrações e reverberações diferentes. Traduzir é como estar em movimento, em trânsito dentro da própria língua e tradição. Desta forma, escrever numa língua já é uma forma de tradução de algo intraduzível — esta uma das definições de poesia para Ungaretti, ${ }^{152}$ o sujeito em sua dimensão real. No esforço da tradução, assim como no da escrita, o poeta se dá conta de sua própria intraduzibildiade, motor propulsor da própria escrita de Ungaretti. Dentro da impossibilidade, ou da intraduzibilidade, há de se percorrer um caminho de um ponto a outro e, a partir dessa constatação, a necessidade da prática da tradução para o próprio fazer da poesia.

Em seu consagrado ensaio "Ragioni d'una poesia", podemos resgatar, nos detalhes, nos dizeres menos óbvios, como a sua reflexão e o seu pensamento se desenvolviam também durante os exercícios de tradução. Enquanto estudava Leopardi, ele traduzia SaintJohn Perse, dizendo a respeito:

[...] enquanto fazia estas observações sobre os textos de Leopardi, por um feliz acaso me ocupava também da obra poética de Saint-John Perse. Desta forma, as minhas observações encontraram um espaço que se estendia do Romantismo até hoje, sem que tivesse que apelar à minha experiência pessoal de poeta ou à poesia italiana recente. ${ }^{153}$

Que o traduzir esteja intimamente ligado ao compor é algo muito bem documentado por Ossola nas refrações que Racine e Góngora provocaram na obra de Ungaretti:

Il richiamo a Racine proprio nella lezione inaugurale, nel 1943, ai corsi di Letteraturai taliana moderna e contemporanea all'Università di Roma [...] bene segnalano il fitto intrecciarsi di traduzione e composizione, anche sul versante dei debiti che il tradurre contrae dal comporre, da Le Stagioni (1920) a Il Capitano (1926), e Ti svelerà (1931) attraverso un complesso lavoro figurale. ${ }^{154}$

O exercício da tradução sempre o acompanhou, tanto na sua criação poética, como nos seus estudos. Ungaretti foi, assim, criando uma coleção de clássicos da poesia europeia, não somente seguindo a continuidade platônica ou petrarquiana (memória e estilo) das ideias, mas também deixando espaço à experiência biográfica, constituíndo uma visão mediterrânea que se estendeu à América Latina, ou voltando às suas origens, buscando alguma inspiração na poesia árabe, como podemos observar em algumas cartas a Bruna. Ungaretti nasce e se forma em lugares e civilizações que são o berço e a encruzilhada de línguas e

152 DELLA GIOVANNA, Ettore. Incontro con Giuseppe Ungaretti . Rai, 1961 (https://www.youtube.com/watch?v=4qbNPMT915A, consultado em 14 de abril de 2019).

153 UNGARETTI, Giuseppe. Vita d'un uomo. Traduzioni Poetiche. Op. cit., p. 36.

154 OSSOLA, Carlo. Op. cit., p. 61. 
tradições nas literaturas, naquele momento: basta pensar em Alexandria, sua cidade natal, onde traduziu Poe e se criou, na cidade de Kavafis, Agostino, Pea e Marinetti; ou em Paris, onde estudou e frequentou o fervilhar de ideias e invenções em seus anos de estudo. Ossola adverte: “[...] para Ungaretti como para Mallarmé e Pound não basta uma só língua para provar da substância verbal do segredo de poesia": ${ }^{155}$ nessa busca pela substância verbal, está em jogo a tradução, pois “traduzir não é 'transformar' nem fazer 'passar' [de uma língua à outra], mas procurar a alma da 'matéria fônica". ${ }^{156}$ Num equilíbrio sutil entre a palavra e o silêncio, presença e solidão, Ossola realça o ensaio “Testimonianza su Valéry”, de 1946, no qual Ungaretti retoma o poeta francês em Varieté $V$, no ensaio dedicado à tradução de São João da Cruz, e escreve, citando Paul Valéry: "mi sembra che l'anima [...] ben sola con se stesssa, di tempo in tempo, tra due silenzi assoluti, non impiega mai se non un piccolo numero di vocaboli e nessuno straordinario. A questo si riconosce che c'è anima in quel momento". Trata-se de uma imagem que ressurge algumas vezes nas cartas endereçadas a Bruna, especialmente em suas tentativas de direcionar a escrita poética de sua amada. No entanto, também ao falar de amor, Ungaretti parece fazê-lo usando a mesma matéria com que trata a poesia, como, por exemplo, na sua Carta n. ${ }^{\circ} 72$, datada de 31 de dezembro de 1966, quando escreve a Bruna:

Amo-te, nem pode-se dizer mais nada. É uma palavra que não quer acréscimos. Diria que é uma palavra que não quer nem mesmo ser pronunciada, surge do silêncio, vai em direção ao silêncio, é um vinculo silencioso. Não sentes, como eu sinto, que quando é a verdadeira palavra, contém e transmite todo segredo, é o segredo. Como se faz para revelar com palavras, o segredo?

\subsection{A PRESENÇA E O PAPEL DA TRADUÇÃO NAS CARTAS A BRUNA}

A cada carta lida, ecoa o que Ungaretti disse sobre a palavra na poesia: “[...] é impotente, a palavra não conseguirá nunca dar o segredo que está em nós; mas aproxima-se dele. Sabese que entre a palavra e aquilo que se quer dizer há sempre uma defasagem enorme". ${ }^{157}$ Quando Ungaretti transcria poetas árabes e Joyce, é como se tentasse transpor o intransponível, dizer o indizível, e todas as suas tentativas ocorrem com um escopo bem preciso: estar com Bruna, sua destinatária e interlocutora. Ungaretti faz-se tradutor por amor ao

\footnotetext{
155 OSSOLA, Carlo. Op. cit., p. 55-56, tradução nossa.

156 Ibid.

157 Citado por MARCONDES, Murilo. O Mundo Sitiado. A poesia brasileira e a segunda Guerra mundial. Apud Encontros com Ungaretti”. In Céu, inferno. Op. cit., p. 360.; também na entrevista à Rai: DELLA GIOVANNA, Ettore. Incontro con Giuseppe Ungaretti . Rai, 1961 (https://www.youtube.com/watch?v=4qbNPMT915A, consultado em 14 de abril de 2019).
} 
começar, através de traduções, a redigir, ainda sem saber, o livro Dialogo, no qual reuniu seus poemas e as réplicas da amada. Ungaretti usa a tradução como motor propulsor para sua criação. Que tipo de tradução é esta que se apresenta nas cartas a Bruna?

Ocorre resgatar Haroldo de Camposl, em seu "Da tradução como criação e como crítica", ${ }^{158}$ para nos aproximarmos das traduções de Ungaretti nos primeiros meses da correpondência endereçada a Bruna Bianco. Ao lermos essas cartas, temos o privilégio de ver, em primeira mão, de que forma alguns dos versos tão conhecidos de Ungaretti foram forjados a partir das traduções. Como observamos anteriormente, Ossola, analisou minuciosamente a relação entre tradução e criação na obra de Ungaretti em seu prefácio ao volume Tradurioni poetiche, de sua obra reunida Vita d'un uomo. Nessas epístolas, temos o laboratório criativo em si, sua mudança e trasformação de uma versão à seguinte, quase a cada dia em que escreve à amada. O que podemos observar aqui é algo que vai além do que Haroldo apresenta como "isomorfismo", resgatando o conceito a partir da leitura de Max Bense, pois, mesmo partindo da língua inglesa (poemas de Joyce) ou da língua francesa (poesia em árabe, cuja versão de partida é certamente o francês), o que Ungaretti faz é algo que extrapola as fronteiras até da recriação. Recordamos aqui brevemente o resgate que o autor faz de Bense:

Admitida a tese da impossibilidade em princípio da tradução de texos criativos, parece-nos que esta engendra o corolário da possibilidade, também em princípio, da recriação desses textos. Teremos, como quer Bense, em outra língua, uma outra informação estética, autônoma, mas ambas estarão ligadas entre si por uma relação de isomorfia: serão diferentes enquanto linguagem, mas, como os corpos isomorfos, cristalizarse-ão dentro de um mesmo sistema. ${ }^{159}$

No poema "È ora famelica", por exemplo, cuja gênese é o poema "A memory of Players in a Mirror at Midnight", de James Joyce, a única parte resgatada e traduzida do poema é a final, os últimos três versos: "Dire hunger holds his hour./ Pluck forth your heart, saltblood, a fruit of tears:/Pluck and devour!", que se transmuta na carta datada de 2 de outubro de 1966: "È ora famelica, la tua ora, o matto./ Strappati il cuore, sangue salato, frutto di pianti./ Strappatelo, e divoralo!”. Portanto, até mesmo a definição de recriação haroldiana parece cair por terra ao analisarmos o movimento de tradução e apropriação que nos oferece Ungaretti. Haroldo de Campos escreve: "Então para nós, tradução de textos

158 CAMPOS, Haroldo de. Da tradução como criação e como crítica. In CAMPOS, Haroldo. Transcriação. Organizado por Marcelo Tápia e Thelma Médici Nóbrega. São Paulo: Perspectiva, 2015, p. 1-18.

159 Ibid. Op. cit., p. 4. 
criativos será sempre recriação, ou criação paralela, autônoma porém recíproca" ${ }^{\text {"160 }}$ — não se pode afirmar que a reciprocidade é mantida, pois dois terços do poema desaparecem na tradução e mais adiante se funde com outra tradução, um trecho de um poema de AlMutanabbi, ${ }^{161}$ e ganha vida própria, como um poema ex novo. Ungaretti parece resgatar de um porto sepulto da sua alma a referência à poesia árabe e, deste poço, recriar sua poética para estar com sua amada. Vimos como já havia traduzido para a coleção Novissima o que reuniu sob o título "Affrica", e parece seguir, com estas traduções, um movimento de escrita e descoberta da poesia, tendo a tradução como veículo para tal descoberta. Esse deslocamento nos remete a uma declaração da poeta contemporânea canadense, Anne Carson - cuja poética verte sobre um forte diálogo com a poesia clássica grega — que admite: "Se soubesse o que é a poesia não teria necessidade de escrever. É algo que busco tateando no escuro". ${ }^{162}$ Ungaretti, em sua entrevista de 1961 à Rai, ao falar sobre o ato de escrever poesia com algo que "vem de uma ideia que atormenta", afirma: "[...] escreve-se alguma coisa, e isso volta novamente e se continua e às vezes é um longo trabalho, às vezes é um trabalho que se cumpre em poucos momentos"; ${ }^{163}$ e continua: “[...] segue-se com o ouvido, e não se sabe o que é este ouvido [...] ele corre atrás do significado, do som, de tantas coisas [...] tudo deve terminar com a combinação e sensação de que o poema se expressou, mas nunca se expressa, estamos sempre descontentes ${ }^{164}$ ” — a busca pelo verso que se encaixe no poema, a busca do poema que expresse, ou traduza, o que se deseja, todo esse esforço e deslocamento como uma busca do próprio significado da escrita.

Duas características da ética e da poética de Ungaretti são ressaltadas por Murilo Marcondes de Moura em seu O mundo sitiado: ${ }^{165}$ o fato de sua poesia "estar na compaixão", ${ }^{166}$ feito um nítido horizonte ético, ao qual corresponde "O adensamento da expressão ou da busca da essencialidade"167 e de o poeta manter um "respeito às circunstâncias da criação", fato que se reflete em sua escolha do título da obra reunida: Vita d'un Uomo. ${ }^{168}$ Estas características acompanham também o percurso das cartas a Bruna, em busca da

\footnotetext{
160 Ibid. Op. cit., p. 5.

161 Nas traduções dessas cartas, podem ser verificados todos os dados sobre os autores nas notas de informação e tradução.

162 Tradução nossa da citação "Si supiera qué es la poesía no tendría necesidad de escribir. Es algo que busco a tientas en la oscuridad", na matéria de LAGO, Eduardo. Anne Carson: La gran paradoja es escribir con placer sobre algo trágico. E1 País. 3 de maio de 2019 (https://elpais.com/cultura/2019/05/03/babelia/1556899710_745273.amp.html, consultado em 3 de maio de 2019.

163 DELLA GIOVANNA, Ettore. Incontro con Giuseppe Ungaretti . Rai, 1961 (https://www.you-

tube.com/watch?v=4qbNPMT915A, consultado em 14 de abril de 2019).

164 Ibid.

165 MOURA, Murilo Marcondes de. O Mundo sitiado. A poesia brasileira e a Segunda Guerra Mundial. São Paulo: Editora 34, 2016.

166 Ibid. Op. cit., p. 77.

167 Ibid.

168 Ibid. Op. cit., p. 79.
} 
essência da palavra, editando seus próprios poemas e oferecendo revisões às criações da jovem interlocutora, mantendo-se, aí, o adensamento da linguagem como característica, alimentado, desta vez, por outro tipo de circunstâncias da criação. O jovem Ungaretti, poeta de trincheira, sentia, mesmo com toda proximidade da morte, a necessidade de escrever "cartas cheias de amor" — permanecer agarrado à vida; o velho Ungaretti, ainda giovanissimo, como afirmava em tantas cartas, completando quatro vezes vinte anos anos, continuava escrevendo cartas cheias de amor, tecendo seu apego à vida, com uma mão, e com a outra, hesitante, ponderou o peso dos anos, refletindo sobre sua obra e sobre o próprio encontro e a relação com Bruna como, talvez, um gesto de loucura. O movimento de profundidade de busca da palavra certa e da experiência vivida, apontado não só por Moura mas também por Henriqueta Lisboa, que escreveu sobre o poeta nascido em Alexandria: “[...] descobrir analogia entre a palavra e o abismo é saber que a palavra só é válida na medida em que se entranha no coração humano, antes de florescer. Há um tempo de expectativa, um estado de germinação, para que a palavra se torne viva" ${ }^{\text {"169 }}$ - é um movimento que pode encontrar sua espera e germinação nos desdobramentos da tradução, na expectativa do envio do poema a quem este foi endereçado, como os versos nascituros nestas cartas.

Entre a claridade e a introspecção, neste sentido, a busca e reflexão sobre como nasce um poema é algo que permeia muitas das linhas endereçadas a Bruna. O sentido parece emergir da própria escrita. Porém, de que forma este procedimento, da criação via tradução — mas também via escrita de prosa poética em forma de carta — pode estar em relação com o porto sepulto do poeta? "O porto sepulto é o que de secreto permanece em nós indecifrável", ${ }^{170}$ diz Ungaretti, sempre carregando seu quinhão de segredo e mistério no fazer da poesia. Ele fala do porto sepulto, segundo Marcondes de Moura, como um "lugar [...] para designar as fontes da criação poética" que "ajuda ainda a pensar uma outra qualidade que (o poeta) atribuía à poesia", ${ }^{171}$ ou seja: "aquela prodigiosa faculdade concedida a alguns homens de usar os objetos do mundo como espelhos imanentes de sua vida moral". ${ }^{172}$ Esse é o moto contínuo que atravessa as cartas: Ungaretti escreve a Bruna mantendo uma dupla visão sobre as coisas, um olho para o mundo externo — as descrições do céu de Roma ou Paris, as árvores do bairro EUR, as minissaias em Londres, o papel de

\footnotetext{
${ }_{169}$ LISBOA, Henriqueta. Vigília Poética. Belo Horizonte: Imprensa Publicações, 1968, p. 137. 170 "Il porto sepolto è ciò che di segeto rimane in noi indecifrabile." (UNGARETTI, Giuseppe. Vita d'un Uomo. Tutte le poesie. Milão: Mondadori, 2010. p. 523, col. "Meridiani”).

171 MOURA, Murilo Marcondes de. Op. cit., p. 83.

172 UNGARETTI, Giuseppe. Verso un'arte nuova clássica. In Vita d'um uomo. Saggi e interventi. Op. cit., p. 14 — texto escrito em 1919 para servir de prefácio a uma segunda edição de Porto sepulto.
} 
parede no hotel, a música no saguão do residence em Grottaferrata ${ }^{173}$ - e outro para o mundo interno - a lembrança das vivências do passado, a descrição do afeto por Paulhan, as lembranças de Apollinaire; é desta forma que Ungaretti se perde nas descrições de Salomé e São João, refaz sua narrativa bíblica três vezes, rasura muitas vezes as páginas em busca da palavra certa, da palavra que é a medida justa para o mundo, o poeta está sempre repescando algo do seu extenso repertório, de sua vasta cultura nesse duplo movimento do olhar, colocando este fiore colto em relação com o que está no mundo antes de trasmutálo em fiore donato para sua amada. É o movimento dialógico que permeia a narrativa. E se faz presente nestas traduções, revelando diálogos sepultos, da própria poesia. O primeiro poema que surge entre as cartas é naquela datada de 30 de setembro de 1966, e o que será mais tarde "Il lampo di una bocca", em sua roupagem final. Tentamos trazer nesta tese alguma novidade ao observar esses procedimentos, usar as cartas para gerar outras hipóteses sobre o que fertilizou, de alguma forma, a criação destes poemas e contrastar com o que até então havia sido observado e regostrado.

Segundo Ariodante Mariani, ${ }^{174}$ então assistente de Ungaretti, há no título do poema a lembrança de uma imagem de um verso de Eugeio Montale de "Elegia di Pico Farnese" (do livro Occasioni, de 1939) _ “Il lampo delle tue vesti è sciolto / entro l'umore dell'occhio che rifrange nel suo/ cristallo di altri colori”. Porém, o que se observa nessa carta é que o verso surge de uma tradução de um poema de al-Mutanabbi, ${ }^{175}$ cujo texto de partida, para Ungaretti, é provavelmente a sua versão em francês. Apresentamos aqui (Tabela 1 abaixo) como o texto surge na carta e como segue até sua versão no livro Dialogo, com nossa tradução e a hipótese montaliana de permeio:

\footnotetext{
173 Todas estas referências serão esclarecidas com a leitura das cartas e respectivas notas. 174 UNGARETTI, Giuseppe. Vita d'un uomo. Tutte le poesie. Op. cit., p. 1136.

175 Di Abiu Al-Tayybb al-Mutanabbi (905-956), considerado um dos grandes poetas da língua árabe. Começou a escrever poesia com nove anos de idade, há registro de trezentos e vinte e seis dos seus poemas. Seus grandes temas são a coragem na batalha, sempre vista como uma metáfora, e a filosofia mística do Islão. Muitos de seus versos, amplamente conhecidos no mundo islâmico, são considerados proverbiais.
} 
Tabela 1: Il lampo della bocca

\begin{tabular}{|c|c|c|c|}
\hline 1 & 1 & & \\
\hline $\begin{array}{l}\text { Perché andai a quella guerra } \\
\text { senza lancia né scudo? } \\
\text { Perché andai a quella guerra } \\
\text { cantando vittoria? } \\
\text { Lei mi ha guardato... La frec- } \\
\text { cia del suo sguardo, la porto } \\
\text { fitta nel cuore. } \\
\text { Mi ha detto: "Buongiorno, sie- } \\
\text { diti accanto a me". } \\
\text { Ascoltavo la musica della sua } \\
\text { voce, cadde in oblio il sof- } \\
\text { frire. }\end{array}$ & $\begin{array}{l}\text { Por que fui àquela guerra sem } \\
\text { lança nem escudo? } \\
\text { Por que fui àquela guerra can- } \\
\text { tando vitória? } \\
\text { Ela me olhou ... A flecha do } \\
\text { seu olho, trago feito furo no } \\
\text { peito. } \\
\text { Me disse: "Bom dia, senta-te } \\
\text { ao meu lado". } \\
\text { Ouvia a música da sua voz, } \\
\text { caiu em esquecimento o so- } \\
\text { frer. }\end{array}$ & & \\
\hline $\begin{array}{l}\text { Posso ripetermi che prima di } \\
\text { me migliaia } \\
\text { d'uomini sono stati feriti mor- } \\
\text { talmente } \\
\text { dal lampo d'una bocca, } \\
\text { non attenua il mio soffrire. } \\
\text { Mutanabbi (Siria 915-955) }\end{array}$ & $\begin{array}{l}\text { Posso repetir a mim mesmo } \\
\text { que antes de mim milhares } \\
\text { de homens foram feridos mor- } \\
\text { talmente } \\
\text { pelo lampejo de uma boca, } \\
\text { não atenua o meu sofrer. } \\
\text { Mutanabbi (Síria 915-955) }\end{array}$ & $\begin{array}{l}\text { Hipótese Montaliana? } \\
\text { Il lampo delle tue vesti è sciolto } \\
\text { entro l'umore dell'occhio che rifrange } \\
\text { nel su } \\
\text { o cristallo di altri colori } \\
\text { "Elegia di Pico Farnese" } \\
\text { (do livro Occasioni, 1939) }\end{array}$ & $\begin{array}{l}\text { Migliaia d'uomini prima di me, } \\
\text { Ed anche più di me carichi } \\
\text { d'anni, } \\
\text { Mortamente ferì } \\
\text { Il lampo d'una bocca. } \\
\text { Questo non è motivo } \\
\text { Che attenuerà il soffrire } \\
\text { Ma se mi guardi con pietà, } \\
\text { E mi parli, si diffonde una mu- } \\
\text { sica, } \\
\text { Dimentico che brucia la ferita } \\
\text { [poema final em Dialogo] }\end{array}$ \\
\hline 3 & 3 & & \\
\hline $\begin{array}{l}\text { Guarda la sera, } \\
\text { Ha la malinconia del volto di } \\
\text { chi } \\
\text { T'ha detto addio, per separarsi } \\
\text { A lungo. }\end{array}$ & $\begin{array}{l}\text { Olha a noite, } \\
\text { Tem a melancolia do rosto de } \\
\text { quem } \\
\text { Te disse adeus, para separar-se } \\
\text { Por longo tempo. }\end{array}$ & & \\
\hline $\begin{array}{l}\text { Ibrahim Ibn Sahl } \\
\text { (Andalusia ?-1248) } \\
\text { [Roma, } 30 \text { de setembro } \\
\text { de 1966] }\end{array}$ & $\begin{array}{l}\text { Ibrahim Ibn Sahl } \\
\text { (Andalusia ?-1248) }\end{array}$ & & \\
\hline
\end{tabular}

Outro poema da coletânea Dialogo, "Stella", segundo Mariani, também possui relação com a poesia árabe: “[...] retorna nesta lírica também a lembrança de um canto árabe de Omar ebn el Farid, que Ungaretti havia lido na tradução francesa de Henri Thille (em Litérature et Orient, A. Messei, Paris, 1921)". ${ }^{176}$ Podemos pensar que o segundo poema traduzido nesta carta, que mais tarde será "Il lampo di una boca", também deve ter sido extraído da antologia de Henri Thill. O Porto Sepolto, título do primeiro livro de Ungaretti, também não deixa de ser outro atravessamento biográfico, pois em 1912 ocorre uma grande descoberta arqueológica em sua cidade natal, com a descoberta de um porto submerso. A descoberta em si está também intimamente relacionada ao vínculo de Ungaretti e os irmãos Thille. A

176 UNGARETTT, Giuseppe. Vita d'un uomo. Tutte le poesie. Op. cit., p. 1132. 
propósito deste descobrimento, reportamos aqui uma nota de Murilo Marcondes de Moura em $O$ mundo sitiado:

Há um dado curioso que envolve intimamente Ungaretti a esse fato. $\mathrm{O}$ porto foi descoberto pelo engenheiro francês Gaston Jondet, que contava entre seus colaboradores com Jean-León Thille; este e o irmão Henri Thille eram amigos muito próximos de Ungaretti em Alexandria. Os dois, engenheiros que se tornariam escritores de valor, tinham no bairro do Mecs uma casa isolada, situada próxima ao mar e ao deserto. A casa abrigava uma biblioteca extraordinária que os irmãos Thille herdaram do pai e que eles próprios continuaram a abastecer, e ali Ungaretti passou muito tempo como ele próprio declarou. Ali também ouviu falar pela primeira vez do porto submerso, que desde então passou a ter para ele uma significação muito profunda. Primeiro, porque o porto datava da era ptolomaica e revelava que Alexandria existira antes de Alexandre. Mas, principalmente, porque para Ungaretti a cidade entre o mar e o deserto representava a pura instabilidade, um lugar em que nada podia durar, e justamente esse lugar tinha guardado algo tão recuado e ainda intacto. É de se notar também a própria contiguidade entre essa descoberta e o mundo da literatura, contribuindo para soldar as associações entre poesia e segredo e entre poesia e memória, tão fundamentais em Ungaretti. 177

Porto Sepolto surge não só como o título do seu primeiro livro, mas também como metáfora de uma arqueologia possível e presente na poética de Ungaretti. Nestas cartas, em particular nestas traduções que mais tarde integrariam o livro Dialogo, há o mesmo movimento de escavação à procura de versos, referências da sua poesia cuja língua o aproxima à sua terra natal. Ungaretti parece voltar através das suas elaborações, das primeiras traduções até o texto final, a este movimento de escavação e descoberta de um local antiquíssimo e enraizado num território de instabilidade geográfica. Cabe talvez relembrar uma observação de Henriqueta $\mathrm{Lisboa}^{178}$ a respeito de sua poética:

Desdenha então, por incômoda, a ordem sintática tradicional; faz do ritmo a força propulsora e limitadora do verso; abandona por inútil a rima; resguarda o pensamento e oferece a imagem; fixa a essência das palavras buscando-as na origem; valoriza a palavra pelo silêncio em que a envolve; cria para ela um ambiente. ${ }^{179}$

Henriqueta Lisboa usa os versos "quando trovo/ in questo mio silenæio / una parola / scavata è nella mia vita / come un abisso" para comentar tal característica, mas é possivel encontrar esta mesma preocupação também na insistência do poeta em retraduzir os versos, uma e outra vez, para encontrar sua medida ideal, como o faz com o poema de Joyce que veremos mais

\footnotetext{
177 E Moura continua: “O poeta se reportou várias vezes ao assunto, mas de modo mais sistemático nos ‘Quaderni egiziani’ de 1931 incluído no volume 'il deserto e dopo”' (MOURA, Murilo Marcondes de. Op. cit. p. 83 nota 137).

${ }_{178}$ LISBOA, Henriqueta. Vigília Poética. Belo Horizonte: Imprensa Publicações, 1968, p. 137.

${ }^{179}$ Ibid.
} 
adiante. $\mathrm{Na}$ Carta n. ${ }^{\circ}$ 9, datada de 4 de outubro de 1966, Ungaretti confessa: “[...] uma das poesias de Joyce eu tive que retocar, pois em algum ponto não soava bem. Há um ponto, lá pelo final, que devo ainda retocar. O trabalho da poesia, você sabe bem, é lento e difícil." ${ }^{" 180}$ Este trabalho lento e difícil é o que apresentaremos no capítulo seguinte como um trabalho de perlaboração do poema, por parte de Ungaretti, e apontamos esta atenção como uma das possibilidades de leitura, uma das veredas possíveis, a se percorrer diante deste volumoso arquivo. O trabalho lento e difícil é o que se requer para, com Lisboa, se "descobrir (uma) analogia entre a palavra e o abismo". Este é o empenho que ressoa em todas as tentativas de tradução e perlaboração do poema: trabalhar entre a medida da palavra e do verso e sua ligação com o humano, com o biográfico, citando ainda Lisboa: “[...] é saber que a palavra só é valida na medida em que se entranha no coração humano, antes de florescer." ${ }^{\text {181 }}$ O que está em jogo aqui é a própria espera e reelaboração, pois, mais uma vez, "[...] há um tempo de expectativa, um estado de germinação, para que a palavra se torne viva." $" 182$

As recriações de poemas de James Joyce constituem a base de outros três poemas do livro Dialogo: "Ora famélica", "Dono" e "Conchiglia". É importante relembrar aqui que o próprio poeta diz à amada: “[...] eis minhas imitações às quais trabalhei somente para estar com você", ${ }^{183}$ — ele avisa Bruna — "ontem, sábado, esperando o sono [...] tomei nas mãos textos de Joyce, você sabe, é um escritor de língua inglesa, que teve papel fundamental no renovamento das letras de hoje”. E continua:

Eram textos de poesia, e, esperando o sono, não os traduzi, só tentei algumas imitações, ou talvez sejam composições, ou melhor, poesias completamente diferentes. São imitações como aquelas que fez Leopardi para a Feuille de J.V. Arnault: você se lembra?: Longe da própria rama / pobre frágil folha / Onde vás? ${ }^{184}$

Ungaretti cita o poema de Antoine-Vicent Arnault, escrito após a queda de Napoleão, cuja tradução leopardiana leva o nome de "Imitazione". O primeiro poema é calcado em "A memory of the Players in a Mirror at Midnight", do qual três versos permanecem como o âmago do poema recriado por Ungaretti. O poema de Joyce aparece em seu segundo livro Poems Pennyach publicado em 1917, o mesmo poema aparece na revista Poesia publicado em Milão em 1920 e em Nova Iorque na revista Dial no mesmo ano. Segundo Ariodante

\footnotetext{
${ }^{180}$ Carta n. ${ }^{\circ}$ 9, datada de 4 de outubro de 1966.

181 LISBOA, Henriqueta. Vigília Poética. Belo Horizonte: Imprensa Publicações, 1968, p. 137.

182Ibid.

183 Transcrição, Carta n. ${ }^{\circ}$ 9, datada de 2 de outubro de 1966.

184 Ibid.
} 
Marianni, ${ }^{185}$ foi a tradução italiana, atribuída a Alfredo Giuliani, ${ }^{186}$ que serviu como base para a recriação ungarettiana: “Orrida fame ha la sua ora./ Strappati il cuore, sangue salato, frutto di lacrime./ Strappa e divora!". Apresentamos nas Tabelas 2.132 .2 abaixo o poema traduzido na carta, sua versão original em inglês e sua versão final no livro Dialogo.

Tabela 2.1: Recriação de três poemas: È ora famélica, Dono e La Conchiglia a partir dos poemas de James Joyce A memory of Players in a Mirror at Midnight, XXXIV, XXVI

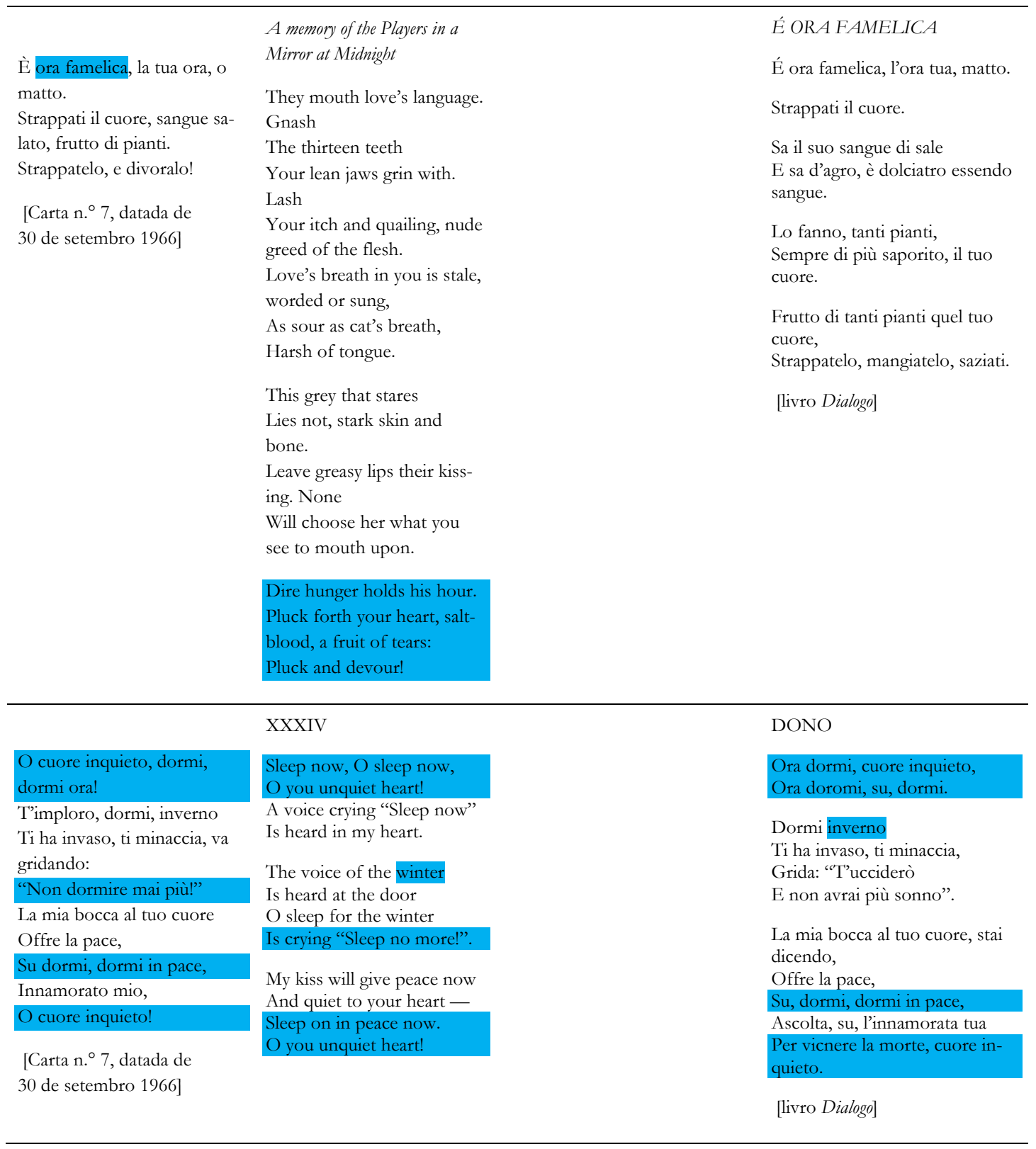

${ }^{185}$ Comentário de Marianni ao livro Dialogo. In UNGARETTI, Giuseppe. Vita d'un uomo. Tutte le poesie. Op. cit., p. 1136.

186 Sugerimos a leitura de MARIANNI, Ariodante. Modelli arabi e joyciani di Ungaretti. Belfagor. Vol. 35, No. 2 (31 Marzo 1980), p. 198-202. 
Tabela 2.2: Recriação de três poemas: È ora famélica, Dono e La Conchiglia a partir dos poemas de James Joyce $A$ memory of Players in a Mirror at Midnight, XXXIV, XXVI

\begin{tabular}{|c|c|c|c|c|}
\hline & XXVI & & LA CONCHIGLIA & \\
\hline $\begin{array}{l}\text { A conchiglia del buio } \\
\text { Se tu, o mia carissima, } \\
\text { premessi } \\
\text { Orecchio d'indovina, } \\
\text { chiederesti: } \\
\text { "Da quale dove il } \\
\text { chiasso si fa strada } \\
\text { Che tra voci incantate } \\
\text { D'un tremito improv- } \\
\text { viso } \\
\text { Mi agghiaccia il cuore?" } \\
\text { Se tu quella paura, } \\
\text { O timorosa mia, } \\
\text { Poi la scrutassi bene } \\
\text { scrutassi bene, } \\
\text { Volgendoti a un futuro } \\
\text { Che non sarà lontano, } \\
\text { Avresti tante da sof- } \\
\text { frire, } \\
\text { Tanto, potendo rispon- } \\
\text { dere solo: } \\
\text { "Dal racconto d'amore } \\
\text { d'un demente } \\
\text { male Solo Or- } \\
\text { mai < unicamente> per- } \\
\text { cepibile } \\
\text { Nell'ora degli spettri. } \\
\text { [Carta n. } 8 \text {, datada de } \\
2 \text { de outubro de } 1966 \text { ] }\end{array}$ & $\begin{array}{l}\text { Thou leanest to the } \\
\text { shell of night, } \\
\text { Dear lady, a divining } \\
\text { ear. } \\
\text { In that soft choiring of } \\
\text { delight } \\
\text { What sound hath made } \\
\text { thy heart to fear? } \\
\text { Seemed it of rivers } \\
\text { rushing forth } \\
\text { From the grey deserts } \\
\text { of the north? } \\
\text { That a mood of thine, } \\
\text { O timorous, } \\
\text { Is his, if thou but scan it } \\
\text { well } \\
\text { Who a mad tale be- } \\
\text { queaths to us } \\
\text { At ghosting hour con- } \\
\text { jurable-- } \\
\text { And all for some } \\
\text { strange name he read } \\
\text { In Purchas or in Holin- } \\
\text { shed. }\end{array}$ & $\begin{array}{l}\text { Se tu quella paura, } \\
\text { O timorosa mia, } \\
\text { Poi la scrutassi meglio, } \\
\text { Volgendoti a un futuro } \\
\text { Che non sarà lontano, } \\
\text { Ti prove- } \\
\text { rebbe accesso di dolore } \\
\text { Mentre la tua risposta } \\
\text { Altro che questo potrebbe } \\
\text { dire: } \\
\text { "Insopportabile quel } \\
\text { chiasso giunge } \\
\text { Dal racconto d'amore } \\
\text { d'un demente } \\
\text { Ormai unicamente per- } \\
\text { Nell'ora degli spettri". } \\
\text { [Carta n. }{ }^{\circ} \text { 9, datada de } \\
4 \text { outubro } 1966]\end{array}$ & $\begin{array}{l}1 \\
\text { A conchiglia del buio } \\
\text { Se tu, carissima, acco- } \\
\text { stassi } \\
\text { Orecchio d'indovina, } \\
\text { Per forza ti dovresti do- } \\
\text { mandare: } \\
\text { "Tra disperdersi d'echi, } \\
\text { Da quale dove a noi } \\
\text { quel chiasso arriva?" } \\
\text { D'un tremito il tuo } \\
\text { cuore ammutirebbe } \\
\text { Se poi quel chiasso, } \\
\text { Dagli echi generato, tu } \\
\text { scrutassi } \\
\text { Insieme al tuo spavento } \\
\text { nell'udirlo. } \\
\text { Dice la sua risposta a } \\
\text { chi l'interroga: } \\
\text { "Insopportabile quel } \\
\text { chiasso arriva } \\
\text { Dal racconto d'amore } \\
\text { d'un demente; } \\
\text { Ormai è unicamente } \\
\text { percettibile } \\
\text { Nell'ora degli spettri". } \\
\text { [livro Dialogo] }\end{array}$ & $\begin{array}{l}\text { Su conchiglia del buio } \\
\text { Se tu, carissima, premessi } \\
\text { orecchio } \\
\text { D'indovina: "Da dove - } \\
\text { mi domanderesti- } \\
\text { Si fa strada quel chiasso } \\
\text { Che, tra voci incantevoli, } \\
\text { D’un tremito improvviso } \\
\text { agghiaccia il cuore?" } \\
\text { Se tu quella paura, } \\
\text { Se tu la scruti bene, } \\
\text { Mia timorosa amata, } \\
\text { Narreresti soffrendo } \\
\text { D'un amore demente } \\
\text { Ormai solo evocabile } \\
\text { Nell'ora degli spettri. } \\
\text { Soffriresti di più } \\
\text { Se al pensiero ti dovesse } \\
\text { apparire } \\
\text { Oracolo, quel soffio di } \\
\text { conchiglia, } \\
\text { Che annunzia il ramme- } \\
\text { morarsi di me } \\
\text { Già divenuto spettro } \\
\text { In un non lontano futuro. } \\
\text { [livro Dialogo] }\end{array}$ \\
\hline
\end{tabular}

Propomos mais uma tabela (Tabela 2.3, na página seguinte), separada da anterior por falta de espaço, apresentando a versão do poema do dia 6 de outubro, Carta n. ${ }^{\circ} 10$, em que Ungaretti propõe três "imitações": uma de Joyce, uma de Ibrahim Ibn Sahl e a última da própria Bruna. Vamos examinar mais uma vez para o poema de Joyce que mais tarde será o poema "La Conchiglia": 
Tabela 2.3: Recriação de três poemas: È ora famélica, Dono e La Conchiglia a partir dos poemas de James Joyce A memory of Players in a Mirror at Midnight, XXXIV, XXVI

\begin{tabular}{|c|c|c|}
\hline & da Joyce & LA CONCHIGLIA \\
\hline & 2 & 1 \\
\hline \multirow{8}{*}{$\begin{array}{l}\text { A conchiglia del buio } \\
\text { Se tu, o mia carissima, accostassi } \\
\text { Orecchio d'indovina, } \\
\text { Per forza ti dovresti domandare: } \\
\text { "Da quale dove il chiasso si fa strada, } \\
\text { Tra i dispersi di echi, } \\
\text { Ed improvvisto tremito } \\
\text { Mi ammutolisce il cuore?" }\end{array}$} & A conchiglia del buio & A conchiglia del buio \\
\hline & Se tu, o mia carissima, accostassi & Se tu, carissima, accostassi \\
\hline & Orecchio d'indovina, & Orecchio d'indovina, \\
\hline & Per forza ti dovresti domandare: & Per forza ti dovresti domandare: \\
\hline & “Tra disperdersi d'echi & “Tra disperdersi d'echi, \\
\hline & Da quale dove il chiasso si fa strada?" & Da quale dove a noi quel chiasso arriva?" \\
\hline & D'un imp tremite & \\
\hline & $\begin{array}{l}\text { D'un tremito } \# \text { il tuo cuore } \\
\text { ammuteliva ammutirebbe. }\end{array}$ & $\begin{array}{l}\text { D'un tremito il tuo cuore ammutirebbe } \\
\text { Se poi quel chiasso, }\end{array}$ \\
\hline \multirow{5}{*}{$\begin{array}{l}\text { Se tu quella paura, } \\
\text { O timorosa mia, } \\
\text { Poi la scrutassi meglio, } \\
\text { Volgendoti a un futuro } \\
\text { Che non sarà lontano, } \\
\text { Ti proverà un proverebbe accesso di do- } \\
\text { lore }\end{array}$} & & Dagli echi generato, tu scrutassi \\
\hline & $\begin{array}{l}\text { Se poi tu quella paura la scrutassi, } \\
\text { (n) }\end{array}$ & Insieme al tuo spavento nell'udirlo. \\
\hline & Tu poi la scrutassi meglio, & Dice la sua risposta a chi l'interroga: \\
\hline & Volgendoti a un futuro & "Insopportabile quel chiasso arriva \\
\hline & $\begin{array}{l}\text { Che non sarà lontano, } \\
\text { latere }\end{array}$ & $\begin{array}{l}\text { Dal racconto d'amore d'un demente; } \\
\text { Ormai è unicamente percettibile }\end{array}$ \\
\hline \multirow{3}{*}{$\begin{array}{l}\text { Mentre la tua risposta } \\
\text { Altro che questo } \\
\text { potrebbe dire: }\end{array}$} & Scoppio ti proverebbe di dolore & Nell'ora degli spettri”. \\
\hline & Proveresti uno scoppio di dolore & \\
\hline & Mentre la tua risposta & 2 \\
\hline "Insopportabile quel chiasso giunge & Altro dire che questo non saprebbe: & \\
\hline Dal racconto d'amore d'un demente & "Insopportabile quel chiasso giunge & Su conchiglia del buio \\
\hline \multirow{4}{*}{$\begin{array}{l}\text { Ormai unicamente } \\
\text { percepibile } \\
\text { Nell'ora degli spettri". }\end{array}$} & Dal racconto d'amore d'un demente & Se tu, carissima, premessi orecchio \\
\hline & Ormai unicamente percettibile & D'indovina: "Da dove - mi \\
\hline & Nell'ora degli spettri”' & domanderesti- \\
\hline & & Si fa strada quel chiasso \\
\hline \multirow{18}{*}{$\begin{array}{l}{\left[\text { Carta } .^{\circ} 9 \text {, datada de }\right.} \\
4 \text { outubro 1966] }\end{array}$} & da Ibrahim Ibn Sahl & Che, tra voci incantevoli, \\
\hline & & D’un tremito improvviso agghiaccia \\
\hline & Come accade alla sera & il cuore?" \\
\hline & Mentre scompare il sole, & \\
\hline & Con uguale malinconia vedo & Se tu quella paura, \\
\hline & Per il nostro non breve & Se tu la scruti bene, \\
\hline & separarci & Mia timorosa amata, \\
\hline & Farsi lontana la tua luce cara. & Narreresti soffrendo \\
\hline & & D'un amore demente \\
\hline & {$\left[\right.$ Carta n.$^{\circ} 10$, datada de } & Ormai solo evocabile \\
\hline & 6 de outubro de 1966] & Nell'ora degli spettri. \\
\hline & & Soffriresti di più \\
\hline & & Se al pensiero ti dovesse apparire \\
\hline & & Oracolo, quel soffio di conchiglia, \\
\hline & & Che annunzia il rammemorarsi di me \\
\hline & & Già divenuto spettro \\
\hline & & In un non lontano futuro. \\
\hline & & [livro Dialogo] \\
\hline
\end{tabular}

A segunda parte do poema "La Conchiglia", que parece ser uma reelaboração da primeira parte, é justamente o que surge na Carta n. ${ }^{\circ}$ 9, datada de 4 de outubro de 1966, a partir do verso "Se tu quella paura o timorosa mia" — há a repetição com variação "se tu premessi" ou "se tu accostassi". Uma única elaboração não basta: o poema inclui duas partes, mas sua segunda parte parece uma nova tentativa, com variações, de completar a primeira parte, o primeiro canto.

A base da segunda recriação de Ungaretti, o que será mais tarde o poema "Dono", é o poema XXXIV do livro Chamber Music de James Joyce, seu primeiro livro de poemas, publicado em 1907. São trinta e seis poemas que, de alguma forma, dialogam com o estilo 
da poesia elisabetana num sentido crítico e também irônico. Segundo Alípio Correia de Freitas ${ }^{187}$ Pound apontou neste livro a inovação no ritmo derivada do simbolismo e o uso de alguns neologismos. Foi uma publicação que encontrou sua luz sob a relutância de Joyce e que se publicou sobretudo por incentivo de seu irmão. Há, supostamente, uma ironia intrínseca ao título da coletânea, pois a questão da música de câmara também alude ao som de urina em penico (chamber pot). Ungaretti parece subverter por completo o sentido das líricas em suas recriações, parece tomar para si o valor da palavra quase isolada e, neste sentido, afasta-se da ideia de um diálogo com o autor do texto de partida. Os poemas de Joyce trabalham com algo de musical, mas a musicalidade e o ritmo impressos por Ungaretti em suas recriações tomam outro sentido. Em Joyce, "shell of the night", concha da noite, deveria indicar, ironicamente, "chamber pot", ou seja, um penico; o ruído que assusta a jovem - a corredeira dos rios do norte — não seria nada mais do que o barulho de alguém urinando, e o medo nasce da leitura de histórias escritas por Samuel Purchas (1577-1626), clérigo inglês que publicou uma série textos sobre viagens, e Raphael Holinshed (1529-1580), cronista inglês cuja obra foi também fonte das peças históricas de Shakespeare. Teria a tradução de Alfredo Giuliani desviado a leitura de Ungaretti? Mais do que uma transcriação a partir do poema de Joyce, Ungaretti parece fazer uso de suas leituras e circunstâncias para criar algo novo, pois o que lhe interessa é a imagem de uma jovem amedontrada pelo que parece ouvir de uma concha, o ruído do mar (o verso lido literalmente, portanto) - e traspõe sua leitura de imediato à sua biografia, ao diálogo com Bruna, que parece então ocupar e assumir o lugar desta jovem que ouve, asusstada, no ruído encapsulado do mar, algo oriundo do futuro. A concha é um oráculo, "che annunzia il rammemorarsi di me / Già divenuto spettro / In un non lontano futuro”, anuncia a lembrança do poeta, já fantasma, num futuro não tão distante. Muito mais do que recriação, trata-se quase de um gesto antropofágico de Ungaretti, ou — para dizê-lo de uma forma mais próxima à nossa tradição — um gesto de plagiotropia.

Faz-se necessário um pequenos excursus teórico, aqui, rememorando o que Marcelo Tápia apresenta em seu posfácio a Transcriação, volume que reúne os ensaios sobre tradução de Haroldo de Campos. Em seu texto, “O Eco Antropofágico: reflexões sobre a trasncriação e a metáfora sanguíneo-canibalesca", ${ }^{188}$ Tápia retoma um texto de Haroldo, "Transluciferação Mefistofáustica”, post-scriptum do seu livro Deus e o Diabo no Fausto de Goethe, no

${ }^{187}$ FREITAS NETO, Alípio Correia de. Uma nota irônica à terminologia feudal em James Joyce. In Música de Câmara. Tradução e introdução de Alípio Correia de Freitas Neto. São Paulo: Iluminuras, 1998.

${ }_{188}$ TÁPIA, Marcelo. O Eco Antropofágico: reflexões sobre a trasncriação e a metáfora sanguíneo-canibalesca. In CAMPOS, Haroldo de. Transcriação. São Paulo: Perspectiva, 2015, p. 215-232. 
qual o autor confere à tradução uma qualidade sanguínea. Ao evocar Homero e Ezra Pound (sua escolha por iniciar seu Cantares com o canto XI da Odisseia), Haroldo cita Hugh Kenner, que teria observado a oferenda de sangue a Tirésias como uma "nítida metáfora para tradução", ${ }^{189}$ e continua: "Tradução como transfusão. De sangue. Com um dente de ironia poderíamos falar em vamprirização, pensando agora no nutrimento do tradutor." ${ }^{190}$ Vamos tomar esta ideia emprestada para pensar a função da tradução destes poemas de Joyce, ou esta apropriação dos mesmos, por Ungaretti. Em seu ensaio, Haroldo também fala da "dessacralização do original" a experiência ao limite, "a rasura da origem, obliteração do original". ${ }^{192}$ Se pensarmos as transformações de poemas de Joyce que se transluciferaram em "Dono" e "La Conchiglia", ainda estaríamos um pouco mais além dos parâmetros antropofágicos e haroldianos, perdendo-se um pouco do que Tápia denomina como identidade relacional (partindo dos conceitos de Haroldo de "isomorfia" ou "paramorfia" na tradução) — o poema é quase todo obliterado, mas algo nele é extirpado, conserva-se uma imagem talvez até tornar-se uma nova entidade. Ainda segundo Tápia:

$[\ldots]$ o texto recriado combina elementos e referentes oriundos do texto de partida com elementos e referentes próprios do contexto em que se insere — dá-se uma hibridização sempre fundamentada na relação, na troca: ambos os textos se modificam no processo de "plagiotropia". ${ }^{193}$

Os poemas de Ungaretti que nascem a partir das traduções citadas ocupam mais o espaço de um "canto paralelo", ${ }^{194}$ ainda para ler Ungaretti — neste recorte das transluciferações presentes nas cartas - através de Haroldo, pensar seu gesto como "um movimento não linear de transformação dos textos", algo que segue "ao longo da história, por derivação nem sempre imediata". ${ }^{195}$

O efeito da fratura não se distancia, porém, de uma obsessão pelo ritmo, mesmo no verso livre, por retomar outras formas clássicas e reinventar a dicção do verso. A observação de Henriqueta Lisboa nos auxilia a pensar este processo:

[...] o ritmo poético não se condiciona à espécie mágica ou encantatória; prende-se embora por fios tênues, à necessidade de índole intelectual a que a palavra não pode fugir. Menos livre, é talvez mais humano. O ritmo

\footnotetext{
189 CAMPOS, Haroldo. Transluciferação Mefistofáustica. In Deus e o Diabo no Fausto de Goethe. São Paulo: Perspectiva, 1981, p. 208, apud TÁPIA, Marcelo. Op. cit., p. 215.

190 Ibid.

191 TÁPIA, Marcelo. Op. cit. São Paulo: Perspectiva, p. 218.

192 Ibid.

193 TÁPIA, Marcelo. Op. cit. São Paulo: Perspectiva, p. 220.

${ }^{194}$ Ideia também apresentado no texto "Transuciferação Mefistofáustica" (In CAMPOS, Haroldo. Deus e o Diabo no

Fausto de Goethe. São Paulo: Perspectiva, 1981, p. 208, apud TÁPIA, Marcelo. Op. cit. São Paulo: Perspectiva, p. 224. 195 Ibid.
} 
de Ungaretti possui estrutura firme, em correspondência a uma íntima harmonia. Cada poema [...] é um conjunto rítmico fechado. ${ }^{196}$

Para encerrar o ciclo das traduções, vamos analisar aqui (vide Tabela 3 abaixo) o poema "La tua luce", que nasce como uma tradução de Ibrahim Ibn Sahl na Carta n. ${ }^{\circ}$ 10, datada de 6 de outubro de 1966.

Tabela 3: La tua luce

\begin{tabular}{|c|c|}
\hline \multicolumn{2}{|c|}{$\underline{\text { Da Ibrahim Ibn Sahl }}$} \\
\hline & Scompare a poco a poco, amore, il sole \\
\hline Come accade alla sera & Ora che sopraggiunge lunga sera. \\
\hline Mentre scompare il sole, & \\
\hline Con uguale malinconia vedo & Con uguale lentezza dello strazio \\
\hline Per il nostro non breve separarsi separarci & Farsi lontana vidi la tua luce \\
\hline Frasi lontana la tua luce cara. & Per un non breve nostro separarci. \\
\hline [Carta n. ${ }^{\circ} 10$, datada de 6 de outubro de 1966$]$ & [do livro Dialogo] \\
\hline
\end{tabular}

Malinconia se transforma em lenteza dello straz̧io; há uma inversão entre os últimos dois versos — "Per il nostro non breve separarci" vai para o final e "Farsi lontana vidi la tua luce" sobe — assim como entre os dois primeiros versos — o segundo, "Mentre scompare il sole", abre o poema, e "Come accade alla sera" se torna "Ora che sopraggiunge lunga sera", aqui sim uma tradução, uma apropriação do poema de Ibrahim Ibn Sahl. "La tua Luce" é um título particularmente importante da coletânea Dialogo, se observarmos esse livro como algo contido e gerado a partir das cartas trocadas com Bruna Bianco. A contar da Carta n. ${ }^{\circ}$ 9, ou seja, desde o dia 4 de outubro de 1966, Ungaretti começa a usar o vocativo Luce, mia Luce, para se endereçar à amada. "La Luce", ${ }^{197}$ como será observado com mais atenção no próximo capítulo, é também o título do livro que o poeta assina em colaboração com Piero Dorazio, editado em São Galo, Suíça, pela Ekker Presse, e que deveria ter visto a luz em 1969, pelo que lemos nesta correspondência, mas só é, de fato, editado postumamente, em 1971. Ainda assim, contém uma dedicatória a Bruna. O tema da luz é presente em toda a poética ungarettiana e no próximo capítulo também analisaremos essa questão com mais profundidade, observando em quais momentos essa refração surge na

\footnotetext{
196 Lisboa, Henriqueta. Vigília Poética, Belo Horizonte: Imprensa Oficial, 1968.

197 É um livro precioso, de artista, raríssimo e de difícil acesso. Durante o período de transcrição das cartas, pudemos consultar o exemplar adquirido por Bruna Bianco. Indicamos o filme em baixa resolução no qual, porém, é possível se consultar o livro: Artphilein Artist's Book: La Luce (https://vimeo.com/53155658, consultado em 14 de abril de 2019.
} 
poesia, nas cartas, na indagação sobre os artistas plásticos com quem conviveu, os sobre os quais dedicou algum tipo de estudo.

Mesmo sem acesso às cartas do mestre à sua amada, Marianni, ${ }^{198}$ então assistente de Ungaretti, observou em seu comentário ao livro Dialogo como a palavra luz reverbera também nos versos que Bruna lhe dedica, como se estivesse contaminada não só pela escrita do poeta, mas também pela própria constante invocação do seu nome: "con la fuggita luce, morirono i colori/ E più non appartiene il vivere/ Che a rincorse di spettri” (do poema "São Paulo"); ou mais adiante: "fuggì la luce,/ Morirono i colori. / Il vivere ora spetta/ Solo ai ricordi.// Macerano il pensiero" (do poema "Variazioni sul tema dela rosa", texto sobre o qual Ungaretti trabalha extensivamente em suas cartas fazendo sugestões às versões enviadas por Bruna). Há uma semente dantesca na repetição da luz como vocativo para se endereçar a Bruna. Há a sensação, em alguns momentos, de uma leitura concêntrica, não só de ascese, mas uma constante varição na intensidade dessa luz. Nesse mesmo período, no qual surgem as traduções-poemas do mestre à jovem aspirante, Ungà se desloca a Paris — "Reencontrei a França que sempre foi de grande encanto para mim: a finesse dos cinzas dos seus céus que em direção ao firmamento se interrompem com leves brancuras e tons celestiais; a medida que está no verde das suas paisagens" [Carta n. ${ }^{\circ} 4$, datada de 18 de outubro de 1966]. Nas últimas linhas desta mesma carta, ele conclui:

Um homem leva consigo o peso de suas lembranças, é um peso que se faz, com a idade, de uma dureza crescente de melancolia. Querida, às vezes apagas as minhas lembranças, invadindo-me a mente e o coração com a tua luz. Então fico como uma criança que balbucia, um desejo incompreensível, e caminha cambaleando até sua luz. Sonho, sonho insensato, amor meu. ${ }^{199}$

Uma imagem que nos remete ao último canto do "Paraíso" da Comédia de Dante, quando se lê: "então fico como uma criança que balbucia, um desejo incompreensível e caminha cambaleando até sua luz" - tão próximo a “ormai sarà più corta mia favella, / pur a quel ch'io ricordo, che d'un fante/ che bagni ancor la lingua a la mammella". ${ }^{200}$

Já agora, nos afastando brevemente das traduções, mas ainda permeados pelo exercício de transcriação que trouxe de volta ao poeta a escrita, observamos o próximo poema (vide Tabela 4, na página seguinte), que vai se delineando como algo que salta da prosa da carta para uma edição em versos. No dia 20 de outubro de 1966, Ungaretti já está de volta

\footnotetext{
198 Comentário de Marianni ao livro Dialogo em UNGARETTI, Giuseppe. Vita d'un uomo. Tutte le poesie. A cura di Leone Piccioni. Milão: Mondadori, (1969) 2009, p. 1136.

${ }^{199}$ Carta n. ${ }^{\circ} 14$, datada de 18 de outubro de 1966, tradução nossa.

200 ALIGHIERI, Dante. La Divina Commedia. Paradiso. Introduzione alla cantica, commento e letture di Emilio

Pasquini e Antonio Quaglio. Milano: Garzanti, 1988, p. 473.
} 
a Roma e, enquanto se desloca até o correio para enviar cartas à amada, escreve-lhe um bilhete, já em versos, que tomará forma do poema "Hai visto spegnersi” (no livro Dialogo). Partindo da formulação da carta — "Cara, a volte cancelli i miei ricordi invadendomi mente e cuore com la Tua luce" — nasce o verso "Ho visto spegnersi negli occhi tuoi/ L'accumularsi dei tanti ricordi”.

Tabela 4: Hai visto spegnersi

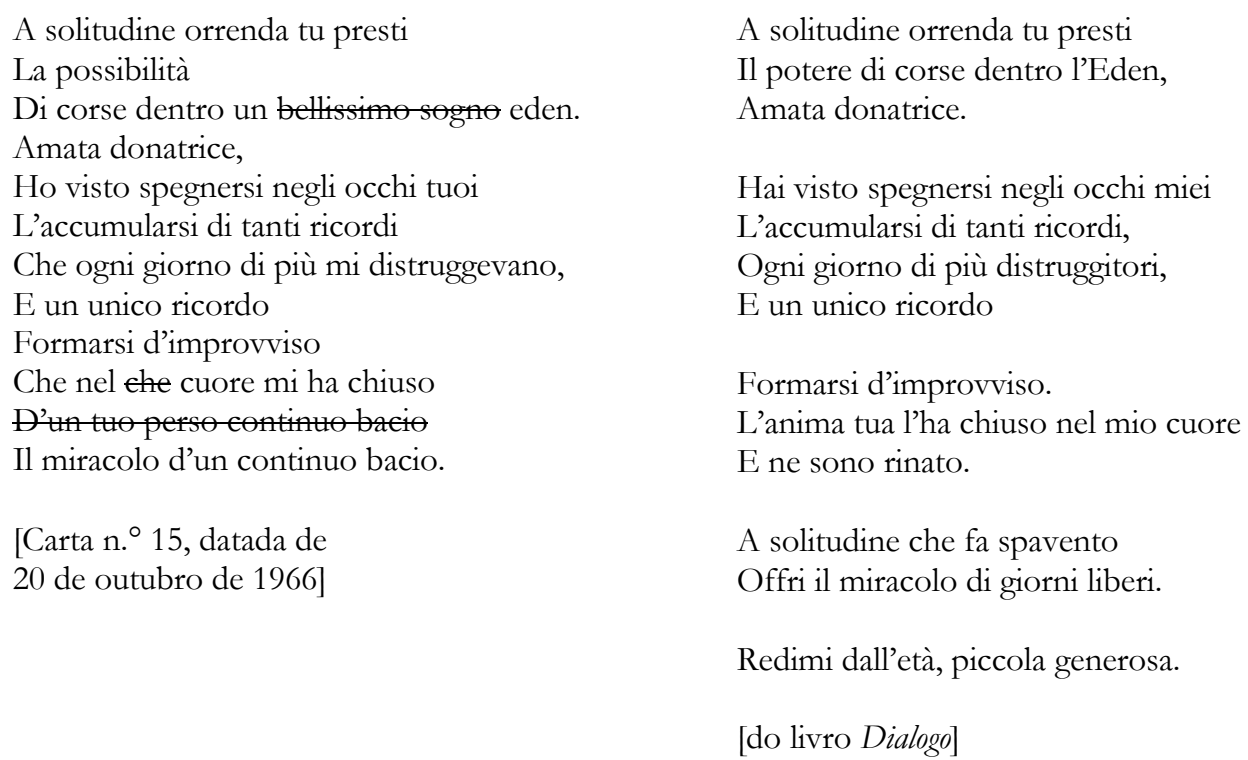

A solitudine orrenda tu presti Il potere di corse dentro l'Eden, Amata donatrice.

Hai visto spegnersi negli occhi miei

L'accumularsi di tanti ricordi, Ogni giorno di più distruggitori, E un unico ricordo

Formarsi d'improvviso.

L'anima tua l'ha chiuso nel mio cuore

E ne sono rinato.

A solitudine che fa spavento

Offri il miracolo di giorni liberi.

Redimi dall'età, piccola generosa.

[do livro Dialogo]

Há uma reformulação completa do sentido de um dos versos do poema, e o que Ungà antes escreve "Ho visto spegnersi negli occhi tuoi / L'accumularsi di tanti ricordi" se transforma em "Hai visto spegnersi negli occhi miei / L'accumularsi di tanti ricordi", que parece dialogar mais diretamente com as linhas da carta anterior: "Cara, a volte cancelli i miei ricordi invadendomi mente e cuore com la Tua luce". Antes, o poeta olha e invoca a amada como seu espelho, pois é em seus olhos que vê o apagamento de tantas lembranças; logo, vê no espelho a sua própria imagem, lembra-se que tantas recordações, tantas lembranças, são as suas - ampla memória, ampla vivência — e faz-se, então, ele mesmo espelho para a amda: "Hai visto spegnersi negli occhi miei". Apagam-se todas as lembraças e uma única, recente, toma o lugar do todo, a presença da jovem amada é um signo de renascimento, redenção da própria idade e passado.

Se a tradução ocupa o espaço de uma ignição para a escrita, o diálogo, a troca e o endereçamento de cartas e versos é algo que completa este trabalho. Nas cartas seguintes, Ungaretti envia muitas sugestões sobe um poema de Bruna e, a partir das correções que 
faz a "Variazioni sulla rosa", surge "Superstite infanzia" (vide Tabela 5.1, abaixo), o último poema do livro Dialogo. A lírica nasce nas cartas como "Replica dell'innamorato all'assente”. O poema surge já com três versões e, já no seu primeiro envio, todo o processo daquilo que chamaremos mais adiante de perlaboração do poema fica à mostra.

Tabela 5.1: Superstite infanzia

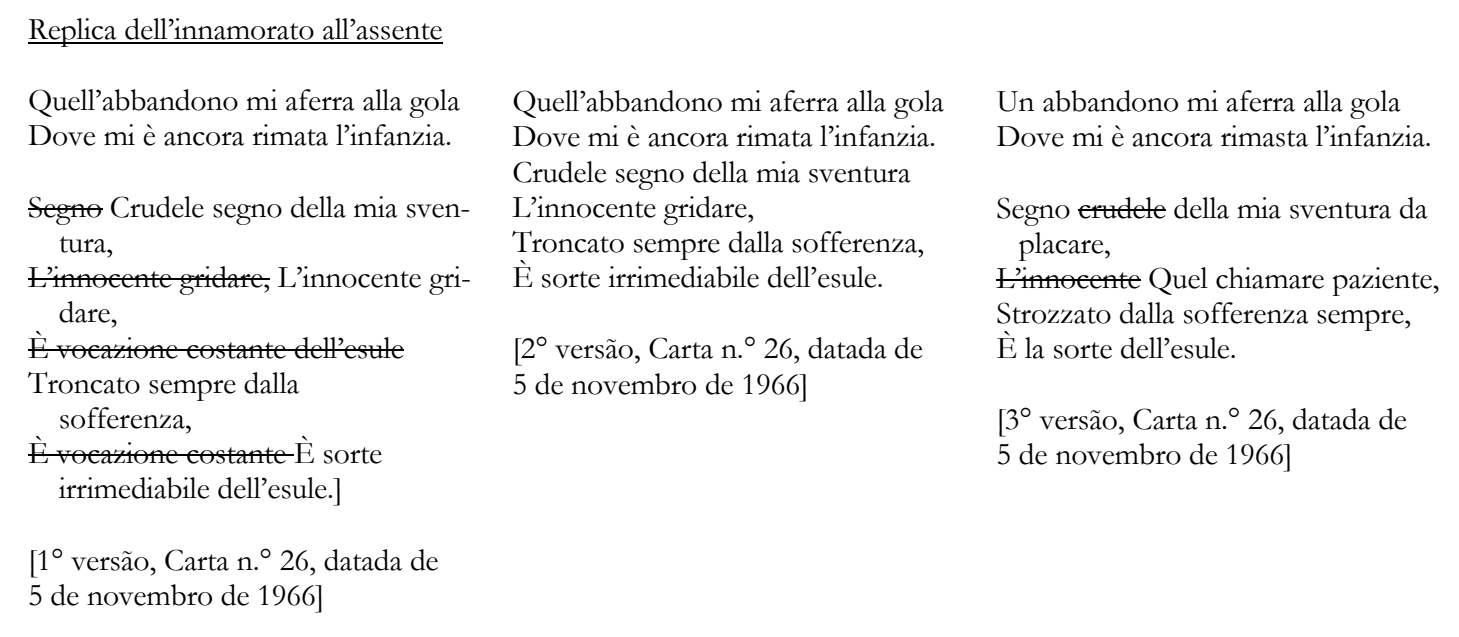

Alguns dias mais tarde, surge uma nova versão do poema: seu destino final, dentro do livro publicado, encontrará duas versões, duas variações como duas partes distintas do poema, algo semelhante ao que observamos, anteriormente, com o poema "La Conchiglia", nascido a partir da tradução — transluciferação — do poema de Joyce. Apresentamos aqui a mesma versão do poema do dia 9 de novembro em confronto com sua versão da parte I (v. Tabela 5.2) final no livro e em seguida com a parte II (v. Tabela 5.3).

Tabela 5.2: Superstite infanæia

Ancora mi rimane qualche infanzia, Modo di abbandonarmi,

Quel fuori di me correre

Che mi piega alla gola.

Sorte sarà dell'esule,

Vuole la mia sventura da placare

L'irrompente chiamarti di continuo

Da sofferenza soffocato sempre.

[Carta n. ${ }^{\circ} 28$, datada de 9 de novembro de 1966]
Un abbandono mi afferra alla gola

Dove mi è ancora rimasta l'infanzia.

Segno della sventura da placare.

Quel chiamare paziente

Da un accanito soffrire strozzato

È la sorte dell'esule.

[do livro Dialogo] 
Ancora mi rimane qualche infanzia, Modo di abbandonarmi,

Quel fuori di me correre

Che mi piega alla gola.

Sorte sarà dell'esule,

Vuole la mia sventura da placare

L'irrompente chiamarti di continuo

Da sofferenza soffocato sempre.

[Carta n. ${ }^{\circ} 28$, datada de 9 de novembro de 1966]
Ancora mi rimane qualche infanzia.

Di abbandonarmi ad essa è il modo mio

Quel fuori di me correre

Stretto alla gola.

Sorte sarà dell'esule?

È per la mia sventura di placare

Il correre da cieco,

L'irrompere chiamarti di cotinuo

Strozzato dal soffrire.

[do livro Dialogo]

O desejo parece ser não perder o verso "Ancora mi rimane qualche infanzia", e tampouco "un abbandono mi afferra alla gola", perlaboração a partir de "Quel fuori di me correre / Che mi piega alla gola", de fato conciliado com duas versões do mesmo poema, duas possibilidades escritas a partir da mesma inspiração. Segundo Marianni, este poema seria o contraponto ideal aos versos que abrem o livro Il Dolore: "tutto ho perduto". Se, de fato, Ungaretti sancionava com tal poema a perda definitiva da infância - "Tutto ho perduto dell'infanzia/ E non potrò mai più/ Smemorarmi in un grido" - a impossibilidade do esquecimento num grito, o grito de um nasciturno, quase trintas anos após ter escrito estes versos, após ter escrito "L’infanzia ho sotterrato / Nel fondo dele notti /E ora, spada invisibile, /Mi separa da tutto", pode agora escrever: "Ancora mi rimane qualche infanzia". Ou, como ele diz na Carta n. ${ }^{\circ}$ 14, datada de 18 de outubro de 1966: "[...] sono come um bimbo che balbetta um incomprensibile Desiderio". O que lhe permanece na garganta, o destino do exilado, preso no fundo, como no poema que abre o livro Il Dolore — "La vita non mi è più, / Arrestata in fondo alla gola, Che una roccia di gridi” - uma rocha de gritos, o mesmo silêncio que parece existir tanto da dificuldade de expressar a dor e a falta, como também o amor. Com este poema, como neste Dialogo, o poeta tenta reencontrar, através do amor renovado, um fragmento daquele "país inocente". 
Nas traduções, como em toda obra de Ungaretti, podemos observar a proximidade entre exatidão da palavra e o percurso de vida. Temos em mente aqui nas linhas que ele endereça a Bruna na sua Carta n. ${ }^{\circ}$ 28, datada de 9 de novembro de 1966, na qual diz: "A arte é paciência, a poesia não, é inspiração; mas a inspiração sem arte qualquer um pode ter". ${ }^{201}$ E, assim, parece retornar nas cartas, na criação e perlaboração do que se iria se tornar o livro Dialogo, uma fidelidade à palavra. Giuseppe Ungaretti, tradutor por amor, como nos versos do poema "Pietà", em que ele se pergunta:

\section{Ho fatto a pezzi cuore e mente \\ Per cadere in servitù di parole?}

Despedacei coração e mente

Para cair na servidão de palavras?

$\mathrm{Na}$ Carta n. ${ }^{\circ}$ 27, escrita entre os dias 7 e 8 de novembro, o poeta senta-se à mesa no tradicional caffè Greco, em Roma, e escreve:

Estou aqui no Café Greco. Um café que já existia no fim do 1700. Aqui sentaram-se Goethe e Leopardi, Dostoieviski, Baudelaire e Gogol. Senta-se indignamente também Unga', num banco estreito coberto de veludo, mas Unga' ama, e está escrevendo para o seu amor, ato que lhe confere a máxima dignidade. Não é, minha alma?202

Amar é o que parece lhe conferir também a dignidade de ocupar um lugar entre os ilustres - claro, com toda a sua pitada de ironia, tipicamente ungarettiana.

201 "L’arte è pazienza, la poesia, no è ispirazione; ma l'ispirazione senza arte può averla chiunque" (Carta n. ${ }^{\circ} 28$, datada de 9 novembro de 1966).

202 Carta n. ${ }^{\circ} 27$, datada de 7-8 de novembro de 1966, tradução nossa. 


\section{4 \\ UMA LEITURA POSSÍVEL}

4.1 UMA LEITURA POSSÍVEL

4.2 PERLABORAÇÃO DO POEMA E QUESTÕES DE CRÍTICA LITERÁRIA

4.2.1 A língua e a confusão entre línguas

4.2.2 Tradução e tradutores

4.2.3 O Barroco

4.3 ARTES PLÁSTICAS

4.3.1 O tempo e a construção da escuta

4.3.2 O caráter europeu da obra e das relações de Ungaretti

4.3.2.1 Picasso

4.3.2.2 Vermeer e Cézanne

4.3.2.3 Fautrier, De Chirico, Savinio, Modigliani, Burri, Dorażio e Cagli

4.4 ARTES, ARTISTAS E INTELECTUAIS NO BRASIL DE UNGÀ 



\subsection{UMA LEITURA POSSÍVEL}

Com o descobrimento de um acervo extenso como o nosso, à sua transcrição segue-se a necessidade de criar uma cartografia que facilite a navegação entre tantas palavras. As notas presentes servem não só como suporte para decifrar personagens e locais citados por Ungaretti, mas também para colocar em pauta questões sobre a prática da tradução. Desta forma, traduzir é também uma ferramenta analítica. Ao transpor as cartas de uma língua a outra, abre-se a junto um caminho para percorrê-las. Conscientes de que não é possível esgotar a análise deste material nos eixos que apresentamos, o que se propõe aqui é uma demarcação inicial, assim como se traçavam os primeiros mapas, valendo-nos de um conjunto de estudos - a fortuna crítica do autor - e analisando temas particularmente recorrentes nesta fração de três anos de correspondência a Bruna. É um recorte possível que deve servir como base para que outros estudos continuem aprofundando, detalhadamente, esse território.

Com a temática amorosa presente nesta correspondência, surgem também outras questões, como por exemplo um espécie de crítica literária muito pessoal de Giuseppe Ungaretti. O poeta explicita sua forma de abordar autores que apresenta a Bruna como se tivesse o intuito de construir um cânone para a jovem poeta em formação. Há, em diversas cartas, sugestões de como Bruna deveria melhorar sua escrita, e entre estas podem ser extraídas algumas definições do que é poesia para Ungaretti. A partir destas questões observadas, traçamos a primeira parte de nossa análise, ou seja a perlaboração do poema e questões de crítica literária. Neste eixo ainda exploramos as meditações sobre a língua italiana e a confusão entre línguas, as traduções de Ungaretti e Bruna e a relação do poeta com alguns de seus tradutores, como por exemplo Bachmann e Celan, enfim o que nas cartas a Bruna surge em referência ao Barroco.

Outro eixo fértil presente nas cartas endereçadas a Bruna é o relato minucioso do vínculo do poeta com as artes plásticas. Nestes anos, Ungaretti colabora com artistas como Cagli, Manzù, Burri e Fontana, e também escreve sobre a obra de Vermeer. No entanto, há outras preciosidades, entre as cartas, como a sua impressão de Picasso após visitar a grande exposição em Paris em 1967 - celebração dos oitenta e cinco anos do pintor - seu relato sobre a morte de Modigliani e sua convivência com os irmãos De Chirico. Neste sentido tentamos explorar um pouco do caráter europeo presente tanto na obra quanto nas relações dos poetas, detendo-nos sobre o que Ungaretti diz a respeito de Picasso, Vermeer, Cézanne, Fautrier, De Chirico, Savinio, Modigliani, Burri, Dorazio e Cagli. 
Enfim, neste recorte, nos propormos percorrer um pouco o caminho das artes, dos artistas e intelectuais com quem Ungaretti manteve relações no Brasil, de que forma estes nomes surgem nas cartas, quais foram os encontros e vínculos.

Outros temas que abordamos ao escolher as cartas não puderam ser explorados com o mesmo afinco, mas estão presentes no recorte da tradução. Neste sentido serão lidas cartas enviadas de Paris, Londres e Israel, além de Roma, com o intuito de apresentar um pouco da vida em trânsito do poeta naqueles anos. Há certo espelhamento entre estas cartas e a prosa de Il Deserto e dopo, pois todos os territórios percorridos não são deslocamentos somente no espaço mas também no tempo e em seu sentimento. O poeta de $I l$ sentimento del tempo está sempre presente entre as linhas. A qualidade diarística das cartas, este fluxo contínuo e assíduo, nos mostra de que forma o pensamento do poeta se desloca no cotidiano - de um lado relatando com enorme atenção seus encontros, com quem almoçou, com quem jantou, a cor do céu naquele dia, como tem seguido seus compromissos de trabalho (elementos circunscritos àquele presente) - e de outro deslocando-se ao passado, à memória, ao tempo findo, mantendo, não obstante, um olhar para o futuro (ainda que embebido pela alegria do encontro com Bruna, enraizado na certeza da finitude da vida). Isso se reflete numa lírica que surge entre o ir e vir das cartas, o poema "Stella", no qual Ungà constata "un tempo ti è concesso troppo breve".

\subsection{PERLABORAÇÃO DO POEMA E QUESTÕES DE CRÍTICA LITERÁRIA}

Usamos um termo oriundo da psicanálise, "perlaboração", como ferramenta heurística para pensar o tipo de trabalho empreendido, o movimento de ir e vir, entre as revisões de Ungaretti dos poemas de Bruna e a sua reescrita dos mesmos. Não tendo acesso às cartas assinadas pela então jovem aspirante poeta para constatar o iter completo dos poemas dedicados ao mestre que farão parte do livro Dialogo, traçamos nossas observações a partir dos comentários e sugestões de Ungà. Na psicanálise, “perlaboração” é um neologismo introduzido por Jean Laplanche e Jean-Bertrand Pontalis, em 1967 - justamente o período em que ocorre esta correspondência - pra traduzir na língua francesa o verbo alemão durcharbeiten ("elaborar", "trabalhar com cuidado"), empregado por Sigmundo Freud para designar o trabalho do inconsciente que é próprio do tratamento psicanalítico. No entanto, que nos interessa, nesse contexto, é o cuidado com que os textos são elaborados a partir da influência e das correções de Ungaretti. 
O encontro entre Bruna e o poeta é marcado pelo desejo expresso da jovem de que o mestre leia seus versos e teça algumas observações críticas a respeito dos mesmos. Lemos isso não só no relato do primeiro encontro, escrito por Bruna (Apêndice I), mas também já na quinta carta do poeta, a do dia 15 e 19 de setembro de 1966, em que ele fala do anacronismo na escrita da jovem e, ao mesmo tempo, de certo encanto que isso lhe provoca:

Para dizer a verdade, quando foste embora eu a li, pareceu-me inútil. Havia uma ênfase, um metro em desuso, não sei o que havia que me perturbava. Depois retomei-a para ler, e descobri ali uma graça, uma honestidade, o modo raro de adivinhar o peso, a qualidade, a novidade, aqui e ali das palavras, e tocou-me, tocou-me subitamente o sentimento, um verdadeiro dom que oferece só a boa poesia, aquele dom que iluminava a ingenuidade daquelas estrofes um pouco antiquadas, que ilumina tudo o que fazes. ${ }^{203}$

Ungaretti começa a delinear uma das funções que exerce no encontro com Bruna: trata-se de uma relação amorosa em que os sentimentos se entrelaçam ao desejo pela criação poética. Por um lado, Bruna dá seus primeiros passos, por outro Ungaretti recobra a inspiração que havia há algum tempo perdido, pois havia seis anos não escrevia nenhum novo poema. Ungà é um mestre que compartilha seu conhecimento, revisa poemas, traduz em parceria e oferece chaves de interpretação para definir o que é um bom poema, sempre sobrepondo uma leitura do texto, de sua poética, e da sua vida - afinal de contas, sua obra, não por acaso, é reunida sob o título Vita d'un nomo. Há muito rigor em delinear o que um bom poema: como se chega à qualidade essencial da linguagem, como deve um poeta despir-se de todo o supérfluo; mas há ao mesmo tempo, contaminando esse rigor, um pacto de indissociabilidade entre o texto e a vida. Os relatos das cartas, assim como muitos poemas, tratam de experiências vividas, da passagem do tempo e da interpretação do mundo. $\mathrm{O}$ poeta destila seu cânone e seu conhecimento vestido de seu bom humor e ironia, oscila entre considerar-se o maior dos maiores, entre os poetas, e redimensionar sua pequenez diante da história da poesia, de que é exemplo um trecho dessa mesma carta:

Não sou nada mais do que um pequeno poeta deste século, no qual até os maiores não podem ser mais do que pequenos poetas, mas até hoje, no alvoroço, no inferno de hoje, - mesmo hoje, a poesia precisa ser uma pessoa que se descobre entre os demais - que instila tanta caridade, tanta fé, tanta esperança que de repente alguém possa lhe dizer; alguém que è tão velho, que percorreu tantos labirintos e deles não sabia mais como sair: "obrigado, Édipo diz obrigado à sua luz oculta que se revela." 204

${ }^{203}$ Carta n. ${ }^{\circ}$, datada de 15 de setembro de 1966.

204 Ibid., grifo nosso. 
O poeta ancião, como ele mesmo se define em diversas cartas, evoca Édipo na primeira carta longa e ensaística que envia a Bruna. À primeira definição do que precisa ser a poesia — "uma pessoa que se descobre entre os demais" — segue-se a associação que carrega em si toda a carga semâtica da palavra luz, presente em todo o conjunto epistolar tanto por ser um dos vocativos com que desígna sua amada, mia luce, quanto presença física nas descrições das manhãs romanas ou nos quadros de Vermeer, e também numa vasta porção da obra poética do autor, que nesses mesmos anos prepara o volume Luce em colaboração com Dorazio. Retomando a associação do poeta, lê-se, no desfecho da tragédia de Sófocles, as palavras de Édipo: "No! Tutto s'illumina, riaffiora. Chiara vita, fatti guardare in faccia. Ultimo sguardo. Luce piena sul mio io! Radici maledette! Amori innaturali! [...]”, ${ }^{205}$ Há, logo no início da correspondência, o prenúncio do fim, da mesma forma que é recorrente, em tantas cartas, o que o poeta chama de "um amor demente", "um amor absurdo", aludindo à ampla diferença de idade entre os dois.

Ainda na carta n. 5 , surgem outros elementos que comentaremos mais adiante, como, por exemplo, a coexistência do relato do presente imediato e seu entrelaçamento à memória do passado. Porém, o pacto de passar para a jovem aprendiz suas razões para uma poesia continua. Entre as descrições do cotidiano no navio Giulio Cesare, o poeta também desenha diretrizes de sua poética para Bruna, é como se estivesse seguindo um novo parágrafo, numa nova edição, de Ragioni d’una poesia, em que dizia:

[...] Refleti, naturalmente como qualquer outro escritor ou artista, sobre os problemas da expressão poética e do estilo; mas não o fiz se não pela dificuldade que com o tempo a expressão me opunha exigindo de ser colocada à altura de corresponder integralmente à vida de um homem. $[\ldots]$ moviam-me razões ocasionais, não sendo um filósofo. ${ }^{206}$

No mesmo ensaio, o poeta diz: "a poesia é forma por sua natureza extremamente sintética”, e ainda: "uma palavra que tende a ressoar de silêncio no segredo da alma [...]". ${ }^{207} \mathrm{E}$ segue, na carta para a amada:

O grande segredo da poesia está na simplicidade da palavra. Se a palavra consegue fazer-se simples, como é um sentimento quando consegue filtrar e se fazer transparente por pureza, tanto até se tornar um espelho para a ansiedade de cada alma - naquele momento uma palavra pode crer-se próxima à poesia. ${ }^{208}$

\footnotetext{
${ }^{205}$ Edição italiana: http://www.luigitonoli.altervista.org/testiallegati/SOFOCLE,\%20EdipoRe.pdf, consultada em 8 de Agosto de 2016. Em português: "Tristeza! Tudo agora transparece!/ Recebe, luz, meu derradeiro olhar!/ De quem, com quem, a quem sou triplo equívoco:/ ao nascer, esposar-me, assassionar". Trad. Trajano Vieira. Édipo Rei de Sófocles. Apres. J. Guinsburg. São Paulo: Editora Perspectiva, 2002, p. 97.

206 UNGARETTI, Giuseppe. Vita d'un uomo. Tutte le poesie. Milano: Mondadori, 2009, p. 5.

207 UNGARETTI, Giuseppe. Op. cit.. Milano: Mondadori, 2009, p. 16.

${ }^{208}$ Carta n. ${ }^{\circ}$ 5, datada de 15 de setembro de 1966.
} 
Os anos em que Ungaretti mantém sua relação com Bruna são os mesmos em que organiza sua obra completa. Ele informa numa deas cartas: "E há o meu trabalho para levar a cabo, muito trabalho, já feito, a ser colocado em ordem, tanto trabalho, que daria a ordem de queimar, se não pudesse organizá-lo eu mesmo". ${ }^{209}$ Ele revê os ensaios críticos que também serão traduzidos e publicados na França, encontra seus tradutores, colabora com diversos artistas plásticos, nesses anos férteis de autoanálise e revisitação da própria obra. Através da escuta da Bruna, o poeta pode também repensar sua relação estética com outros autores e artistas, pode medir-se em relação a eles, surgindo, assim, também um pretexto para repensar o seu próprio percurso. Em alguma medida o poeta reconhece na jovem um talento e um destino para a poesia, por isso, grande parte da troca que ocorre entre eles segue nessa direção: há sempre a intenção de mostar como a forma da expressão de Bruna poderia ser mais simples, mais essencial. Quase um ano após o primeiro enconto, o poeta continua oferecendo à jovem aquilo que possui um valor imenso e atemporal para qualquer iniciante na arte do verso, como quando diz: "mais as coisas são ditas sem levantar a voz e sem declamar, mais são poéticas. As mais poéticas são quase 'sussuradas". ${ }^{210}$

\subsubsection{A língua e a confusão entre línguas}

O bilínguismo de Ungaretti encontra esta segunda língua que agora Bruna domina e que talvez faça parte, de forma muito mais intensa, do seu cotidiano em relação ao italiano. A jovem trabalha usando a língua portuguesa, encontra-se há mais de dez anos no Brasil, onde conclui seus estudos superiores, graduando-se em Direito pela Pontíficia Universidade Católica de São Paulo. O italiano, para Bruna, parece circunscrito aos livros — aos poucos a que tem acesso - à fala no âmbito do núcleo familiar e aos poucos amigos italianos. Durante o trabalho de transcrição das cartas, Bruna relatou que sentia tanta falta de ouvir a língua italiana na sua juventude que, em determinados momentos, entrava no Consulado — então sito à avenida Higienópolis — somente para observar os que lá estavam, podendo assim ouvir a sua língua materna. Talvez algum anacronismo nos versos a tal língua em desuso, como diz Ungà — surja dessa distância que se interpõe entre Bruna e a sua língua materna, o italiano, que já se mistura ao portugês, irremediavelmente. É o caso, por exemplo, de quando o poeta lhe pergunta qual o sentido que ela atribui ao conceito de predestinação, como na carta:

\footnotetext{
${ }^{209}$ Carta n. ${ }^{\circ} 39$.
}

210 Carta n. ${ }^{\circ} 227$. 
Aquele poema teu do "amor protetor" é bonito. A "predestinação" na tradição, talvez eu já o tenha dito, no significado agostiniano, tem, nos Jansenistas - Pascal, Racine (Fedra) - um valor sig terrível. Tudo e como poderia ser diferente? - está previsto predestinado pelo Eterno na mente de Deus. É também a culpa que amaldiçoa irremediavelmente. Dás à predestinação um valor distinto? ${ }^{211}$

Nesse caso, podemos pensar que a distância não é tanto entre as línguas mas sim do contraste entre o conhecimento profundo de Ungaretti, que associa à palavra o janesismo, atribuindo-lhe outra carga semântica.

Noutra circunstância, o poeta tenta esclarecer uma incomprensão que surge de um erro de tradução, resultante do uso de um falso cognato. Trata-se do verbo tornar-se em português, que em italiano traduzir-se-ia "divenire", e que Bruna traduz simplesmente como tornare, que, na verdade, em português seria "voltar", donde a confusão:

[...] (usi tornare spesso in un significato che non ha in italiano: tornare significa venire di nuovo a un posto da un altro, o semplicemente venire in mente di nuovo; oppure, come nell'espressione questi "conti non tornano", ehe significa che quei conti non riescono a ritrovare la loro verità, la loro esattezza: "questi discorsi non mi tornano", non mi persuadono, cioè, non hanno nella mia mente, una loro idea formatasi in precedenza, to che è quella che penserei di simili fatti se cosí fossero secondo il giusto, avendo in gen un gitu dorendo pensare secondo verità, e che quell'idea vera non torna per quei discorsi che sono dunque tentativi d'ingannare) ("quei discorsi non tornano da un'idea, da una persuasione che in precedenza m'ero fatto d'una data cosa, dato il mio modo d'intendere le cose, ecc.). ${ }^{212}$

Esta carta foi, certamente, uma das mais difíceis de se traduzir, pois o jogo da confusão não é traduzível e, portanto, foi apenas explicado numa nota de rodapé.

No campo da confusão entre línguas, da composição e do pensamento de um indivíduo bilíngue, podemos acessar o pensamento da escritora e pesquisadora argentina Sylvia Molloy, ${ }^{213}$ que, em seu livro Viver entre linguas, explora, em breves crônicas que mesclam suas lembranças a reflexões mais profundas, as arapucas que enfrentam os falantes de diversas línguas, desde a infância. A autora diz que "cada idioma tem seu território, seu tempo, sua hierarquia", ${ }^{214}$ e há uma cartacterística interessante neste diálogo, que é uma longa conversa escrita entre dois sujeitos que viveram experiências de desenraizamento e busca por uma pátria através do domínio da língua. Podemos supor que, por trás do interesse de Bruna, também há um desejo de manter um elo com o seu país natal, com uma língua que também foge ao cotidiano. Esse interesse

\footnotetext{
211 Carta n. ${ }^{\circ} 40$.

212 Carta n. $^{\circ} 123$.

${ }^{213}$ MOLLOY, Sylvia. Viver entre línguas. Trad. Julia Tomasini e Mariana Sanchez. Belo Horizonte: Relicários, 2018.

214 MOLLOY, Sylvia. Op. cit. Belo Horizonte: Relicários, 2018, p. 15.
} 
encontra em Ungaretti — como um conteúdo em busca de um continente — não apenas a profundidade do conhecimento, o acolhimento amoroso, mas, em alguma medida, também uma simetria da experiência de desenraizamento, uma questão de identidade em aberto. É importante relembrar, como bem coloca a professora Lucia Wataghin, ${ }^{215}$ a relação íntima e profunda do poeta não somente com a língua italiana mas também com o francês e em certa medida com o árabe e tantos outros idiomas, pelo fato de haver nascido e se criado na cidade egípcia de Alexandria no final do século XIX:

\begin{abstract}
A percepção dos problemas inerentes à natureza da língua é particularmente aguda em Ungaretti, não somente em virtude de sua vocação poética, mas também porque Ungaretti é bilíngue (ítalo-francês), e nos primeiros 24 anos de sua vida vive no Egito, em contato cotidianamente com uma terceira língua, o árabe. ${ }^{216}$
\end{abstract}

A questão territorial da língua, como apontada por Molloy, transcende o deslocamento físico, tratando-se também de outro deslocamento íntimo, da vida interna de cada sujeito e como ela é vivida no âmbito de cada idioma. Podemos pensar que, por haver se formado estudando em francês, num colégio suíço no Egito, Ungaretti pode ter vivenciado algumas peripécias semelhantes àquelas narradas por Molloy, ainda que num momento histórico distinto. Ao abordar a questão do território da língua, a autora argentina descreve como o seu colégio era dividido em duas metades: inglês de manhã, espanhol à tarde. $\mathrm{O}$ aluno que falasse espanhol durante o período da manhã era castigado. Havia, porém, códigos secretos entre os jovens alunos, e certas coisas eram ditas apenas em espanhol, como por exemplo as piadas de sacanagem. Em casa, a autora vivia outra divisão: falava em espanhol com a mãe e em inglês com o pai. Por fim, ela descreve a ação de switcheo, ou seja, o ir e vir entre línguas, a troca de uma para a outra como se fossem acessados canais diferentes de comunicação, e conclui: "the switching is effortless". ${ }^{217}$ Por sua vez, no caso em estudo, o ir e vir entre o italiano e o português — nas traduções que Ungaretti e Bruna fizeram juntos, assim como as correções que o poeta faz nos versos da jovem - não parece tão effortless. E Ungaretti aborda esta questão com enorme sensibilidade em suas respostas à amada.

O que observamos como questões relacionadas à crítica literária, nessas missivas, é justamente a relação que Ungaretti parece tecer, em suas crônicas a Bruna, entre os autores que aprecia e os que ele encontra, aqueles com os quais convive, mas também sua atenção

\footnotetext{
215 WATAGHIN, Lucia. Giuseppe Ungaretti: Idee su poesia e tradurione. Libri e Riviste d'Italia. La traduzione Saggi e Documenti II. Supplemento al N. ${ }^{\circ}$ 535-538 (settembre-dicembre 1994). Ministero per i beni culturali e ambientali: Roma, tradução nossa. 216 WATAGHIN, Lucia. Op. cit, p. 177.

217 MOLLOY, Sylvia. Viver entre línguas. Trad. Julia Tomasini e Mariana Sanchez. Belo Horizonte: Relicários, 2018, p. 16.
} 
máxima à lingua, sua relação íntima e profunda com ela. Isto fica claro quando ele fala da preocupação com suas traduções e do profundo apreço pelo trabalho dos seus traduores. Mais uma vez podemos pensar nesse aspecto como algo muito arraigado ao trabalho do poeta e à sua vida. Acompanhando novamente o pensamento de Wataghin:

Talvez esta própria experiência de múltiplos contatos com línguas diferentes, junto àquela do descentramento em relação ao centro constituído da "pátria" distante, na qual fala-se a língua materna de Ungaretti, é um dos fatores determinantes do caráter "dramático" da relação do poeta com a tradição: uma relação que constitui a condição indispensável da sua criação poética. ${ }^{218}$

A "música das palavras" 219 — conceito recorrente em Ungaretti e filtro ao qual ele submete não apenas os versos mas também a prosa — se faz presente também nas indicações sobre os poemas de Bruna, especialmente nos primeiros dois meses da correpondência. Sempre delicado em suas observações, diz: "Transcrevi os versos do nosso jeito de sempre. Tens no ouvido um ritmo perfeito. Depois de tê-la revisitada, envia-me uma cópia!’. ${ }^{220}$ Nessa mesma carta, ele transcreve o poema de Bruna, assinando com seu punho o nome da amada, e sobre o corpo do texto rasura e tece uma série de sugestões. Surge aqui mais uma vez o que parece ser uma sutil confusão entre línguas. O verbo transbordar em português e a explicação de Ungà sobre a origem e a entrada da palavra na língua italiana: “[...] trasbordare é um neologismo que entrou na língua em 1870 e significa passar um objeto de um navio ao outro". ${ }^{221}$ Bruna parece usar o verbo em italiano atribuindo-lhe o sentindo de "derramar", "sair das bordas", "inundar as margens". 222 Ungà aponta outro sentido em italiano. ${ }^{223}$ Deixamos de traduzir algumas cartas que se delongam na explicação do uso dos pronomes tu e te em italiano. Ainda que alguns trechos das mesmas nos ajudam a pensar questões relevantes sobre a perlaboração da língua e do poema, a tradução na íntegra dessas cartas requer muitas notas e dificilmente transmitiria com a mesma leveza o sentido em sua tradução para o português.

A carta datada de 13 de dezembro de $1966^{224}$ apresenta a terceira longa explicação de Ungaretti sobre o uso dos pronomes tu e te, onde ele justifica sua tendência típica do

\footnotetext{
218 WATAGHIN, Lucia. Giuseppe Ungaretti: Idee su poesia e tradurione. Libri e Riviste d'Italia. La traduzione Saggi e Documenti II. Supplemento al N. ${ }^{\circ}$ 535-538 (settembre-dicembre 1994). Ministero per i beni culturali e ambientali: Roma, p. 178, tradução nossa.

219 Ibid.: "[...] per esempio in rani a proposito delle sue letture giovanini di Mallarmé, citati da Leone Piccioni, in Vita di Ungaretti, Rizzoli, Milano, 1979, p. 37”.

220 Carta n. ${ }^{\circ} 16$.

221 Carta n. ${ }^{\circ} 19$.

222 Segundo o Dicionário Priberam da Língua Portuguesa, verbete transbordar (https://dicionario.priberam.org/transbordar, consultado em novembro de 2018).

223 trasbordare v. tr. [der. di bordo, col pref. tras-, sull'esempio del fr. transborder] (io trasbórdo, ecc.). - Trasportare da una nave a un'altra persone o cose: $t$. i passeggeri, il carico. Per estens., con riferimento a treni, o altri mezzi di trasporto: $i$ viaggiatori furono trasbordati su un altro autobus; anche con uso intr.: l'aereo aveva un guasto a un motore e $i$ viaggiatori furono fatti trasbordare, dovettero trasbordare. (http://www.treccani.it/vocabolario/trasbordare, consultado em novembro 2018).

224 Carta n. ${ }^{\circ} 59$.
} 
italiano falado na Toscana e recomenda à amada seguir seu próprio "ouvido" — "segui l'orecchio" - para identificar o que é correto, sendo essa mais uma amostra do critério da “música das palavras". Porém, por trás do uso do pronome, há também uma justificação de cunho afetivo. Há a busca por uma língua nova, uma língua inaugural que possa expressar o amor nascente; essa mesma língua, porém, de forma contraditória, seria a língua da infância, a língua da sua memória afetiva no Egito, a língua que ouvia ao seu redor. Entre recuperar o passado e recriar algo novo, é como se houvesse a necessidade de refazer uma língua a partir do encontro:

Io abuso del te, quando ti scrivo, perché con te ho bisogno di ritrovare quella lingua che sentivo parlare quando imparavo a parlare. Non sto imparando a parlare con te? Non stai imparandomi a parlare? Non sono rinato nelle tue parole che hanno inventato per me l'amore, le prime parole terribili e dolci che salirono alle labbra umane? Non sono quelle le parole, parole di terrore e di speranza, che andiamo ripetendoci all'unisono? ?25 $^{225}$

A língua é matéria que preocupa Bruna, que tenta domá-la, naturalizá-la roçar sua língua literára à língua do poeta, queixa-se que deve estudá-la, assim como sente a pressão de estudar a literatura italiana. Ungaretti aconselha que não aprenda a poesia com os professores — basta um manual, diz — o trabalho da poesia é feito noutro contexto. E sobre o estudo da língua, afirma: "A língua deverá ser estudada, mas não podes deixar um trabalho tão pesado para outro momento?" ${ }^{226} \mathrm{~A}$ julgar da resposta de Ungà, parece haver uma queixa de sua jovem amada sobre o excesso de trabalho e a preocupação com os afazeres literários. A língua serve também para inferir uma filiação poética, como declara o poeta: "Sou da língua d'oc. Sou provençal, sou catalão, sou, não obstante a origem de Lucca, da língua do sim". ${ }^{227}$ E não haveria um encaixe mais adequado do que este: no âmbito de uma correspondência amorosa, reconhecer uma filiação aos provencais, pese circunstancial. Mas volta-se sempre à raiz desenraizada do seu italiano lucchese, essa língua da infância, que ele tenta recuperar nas cartas a Bruna, é mais uma refração do tensionamento entre memória e inocência. "Les personnages de notre drame, les artistes du premier quart du vingtiéme siécle, sont la mémoire et l'innocence". ${ }^{228}$ Em 1926, Ungaretti já explicitava elementos fundamentais da sua póetica alinhando-a ao âmago do moderno, entre a historicidade e a volta a um primitivo puro, o que aproximamos aqui às considerações de Czesław Miłosz a respeito do

\footnotetext{
225 Ibid.

226 Carta n. ${ }^{\circ} 135$, datada de 17 de março de 1967.

227 Carta n. ${ }^{\circ} 128$, datada de 4 de março de 1967.

228 UNGARETTI (1974, p. 137): “As pessoas do nosso drama, de artista do começo do século XX, não a memória e a inocência".
} 
modelo de Oskar Miłosz: ${ }^{229}$ " [...] é dinâmico, assim como o de William Blake, e o movimento histórico toma a forma de uma tríade: o tempo da inocência, o tempo da queda e o tempo do resgate da inocência." ${ }^{230}$ No entanto, para Ungaretti, não parece haver uma sobreposição óbvia entre memória e queda. A língua mais rica é a língua da infância, e o convite do professor Eros Segui, da Universidade de Belgrado a Ungá contém o seguinte apelo:

Caro professore, c'è anche un po' di Lucca nel mio invito, ero compagno di scuola di Benedetti e di Del Beccaro. C'è un po' di quella Lucca dove si parla, come lei dice, la lingua più ricca d'Italia. Posso pregarla di farmi rispondere con gentile sollecitudine, così che possiamo procedere ai lavori d'organizzazione? ${ }^{231}$

A preocupação com a língua enquanto idioma e linguagem poética atravessa alguns ensaios de Ungaretti, que já em Ragioni d'una poesia dizia: "Indefinido como ainda é, o século XX, procura sua própria língua”. E è nessa busca, entre memória e inovação, que se insere a língua da poesia para além do sentido, a língua que está na escuta. Sobre sua leitura em Londres, ele diz a Bruna:

Querido amor meu, o que mais fiz? Estive na televisão para ler a primeira parte de Pietà.232 Em italiano, é claro. Alguns poetas depois, numa mesa redonda, comentaram minha recitação para dizer que a poesia, se é poesia verdadeira, poderia ser compreendida ouvindo-a, mesmo sem entender a língua. Será verdade? Os jurados disseram que sim, como já havia dito Mallarmé. ${ }^{233}$

\subsubsection{Traduções e tradutores}

Enviarei em breve o poema para que dês uma olhada. Acredito que, pelo menos a metade que já está feita, em $\underline{\mathrm{O} \text { Mergulhador quase todas }}$ as dificuldades tenham sido superadas, e nasceu um belo poema italiano com os ritmos certos da nossa língua, e os vocábulos que calçam perfeitamente os significados do original. ${ }^{234}$

Em suas conferências reúnidas sob o título L'invenzione della poesia moderna: Lezioni brasiliane di letteratura (1937-1942), curado por Paola Montefoschi, Ungà resume: "L'italiano è dunque per natura una lingua poetica". ${ }^{235}$ Outras reflexões sobre língua, traduzibilidade e poética também surgem na sua troca epistolar com Bruna. Há, na primeira fase, uma explosão da

\footnotetext{
${ }^{229}$ MILOSZ, Czesław. O testemunho da poesia: seis conferências sobre as aflições do nosso tempo. Curitiba: Editora da UFPR, 2012, p. 58. 
criação poética que nasce a partir da tradução — traduzir para estar juntos, traduzir imitando - mas esta questão foi abordada de forma mais detalhada no capítulo anterior. Noutros momentos, surgem relatos das traduções da obra de Ungà a serem publicadas na França, nos EUA, na Alemanha ou na Suécia, assim como crônicas sobre seu planos e encontros com os tradutores. Num terceiro momento, há uma troca entre Ungaretti e Bruna sobre as traduções de poemas de Vinícius de Moraes — isto já nas últimas cartas — o que coincide com o período em que Vinícius encontrava-se em Roma ocupando o cargo de embaixador. Nesta mesma época, Chico Buraque de Hollanda encontra-se exilado com Marieta Severo, viviam em Roma e sua primeira filha nasce na capital italiana, onde há um grupo de brasileiros que se encontra amiúde. Ungà, que os encontra com frequência, se diz "brasileiro de adoção".

No capítulo anterior privilegiamos tratar questões que surgiram do entraleçamento entre tradução e criação, assim como questões de intertextualidade ou a própria angústia da influência. Já aqui, nossa intenção é ampliar a descrição sobre as cartas, seguindo o movimento dinâmico das relações entre o poeta e seus tradutores.

$\mathrm{Na}$ carta citada acima, o poeta frisa: "[...] nasceu um belo poema italiano com os ritmos certos da nossa língua". A preocupação em verter o poema para o italiano enlaça o conhecimento profundo e meditado sobre as características da língua com a reflexão sobre quais caminhos percorre a tradução de Ungaretti, que é sempre bastante autoral. Relembramos aqui "L'indole dell'italiano", entre os textos compilados por Montefoschi, no qual o poeta observa: “[...] para o italiano, não sua abstração, não sua parte convencional, mas em sua sintaxe está sua realidade, está na construção. As palavras em si, [...] seu próprio valor fonético, possuem em italiano um valor construtitvo". ${ }^{236}$ Como adverte Wataghin, ${ }^{237}$ o poeta parece descrever como um verso pode ou deve ser dobrado para encontrar a sua medida em italiano, e é justamente isto o que ele parece relatar a Bruna: uma busca por palavras que se encaixem - calzanti - perfeitamente de uma língua à outra.

Segundo Wataghin, "para além dos motivos estritamente relacionados às razões 'poéticas' [...]”, o que justifica “a operação de transformação substancial dos textos traduzidos”, na visão de Ungaretti, é o fato de que a língua italiana, sendo incapaz de se adaptar, força o poeta a dobrar o texto estrangeiro a outra estrutura e fazer com que siga o próprio

236 UNGARETTT, Giuseppe. Invenzione della poesia moderna: Lezioni Brasiliane (1937-1942), a cura di MONTEFOSCHI, Paola. Napoli: Edizioni Scientifiche Italiane, 1984, p. 75, tradução nossa.

237 WATAGHIN, Lucia. Giuseppe Ungaretti: Idee su poesia e traduzione. Libri e Riviste d'Italia. La traduzione Saggi e Documenti II. Supplemento al N. ${ }^{\circ}$ 535-538 (settembre-dicembre 1994). Ministero per i beni culturali e ambientali: Roma. 
verso e a própria sintaxe. ${ }^{238}$ Para reforçá-lo, basta, neste caso, não só reler outras traduções de Ungaretti, mas colocar lado a lado "O mergulhador" e "Il tuffatore". Até a divisão dos versos, em certos momentos, assume uma forma distinta em italiano, havendo também alguma mudança no sujeito em que se conjuga o verbo, algum acréscimo ou redução da pontuação, por exemplo: ${ }^{239}$

$[\ldots]$

És a princípio doce plasma submarino

$[\ldots]$

Nele soterro a mão como a cravei criança

Noutro seio de que me lembro, também pleno...

Mas não sei... o ímpeto deste é doído e espanta

O outro me dava vida, este me mete medo. $[\ldots]$

È sulle prime un dolce plasma sottomarino

$[\ldots]$

$V i$ sotterro la mano, com bimbo, ricordo la ficcavo In altro seno, Anche ricolmo...

Ma non so... questo ha impeto dissennato, spaventa L'altro mi dava vita, questo mi fa paura.

A métrica e alguma rima do poema de partida não prevalecem como elementos fundamentais a serem preservados na tradução. A busca por um ritmo, por uma cadência, é um elemento que atravessa toda a pesquisa poética de Ungaretti e se imprime na observação do cotidiano. É isso que podemos observar de forma única em sua escrita epistolar dedicada à amada. Desde as primeiras traduções de Joyce em que diz: “[...] transcrevo ainda minha poesia partindo de Joyce, para te indicar quanto trabalho custa consertar o ritmo, levando em conta a sintaxe, a posição dos vocábulos, dos valores fônicos das sílabas", ${ }^{240}$ até a observação do ritmo do sono de Bruna: “[...] dormes, e sem possibilidade de movimento ouço o arquejo do teu sono calmo, um ritmo, um ritmo harmoniosíssimo", ${ }^{241}$ ou o ritmo ditado pelas gravatas recebidas de Bruna: "havia tuas primeiras gravatas e, desde aquele dia, nenhuma outra gravata me amarra o pescoço, e dá ritmo, ritmo do amor à minha voz", ${ }^{242}$ ou ainda o ritmo dos beijos que possibilitam a comunicação entre almas dos amantes: “[...] assim sinto a tua alma, sinto-a arquejar devagar, responder ao ritmo da minha, devagar, e aquele sussurro dá poesia aos lábios, minha luz, aos nossos labios que possuem um leve estremecimento de consenso"243 — há uma permeabilidade entre vida e escrita, o ritmo impresso nos versos escritos e traduzidos assim como na percepção cotidiano.

Mais adiante no poema, Ungaretti destaca um verso inteiro de sua quadra - "E ponho-me a cismar mulher, como te expandes!" - que acaba assumindo uma posição

\footnotetext{
238 WATAGHIN, Lucia. Op. cit.

239 UNGARETTI, Giuseppe. Vita d'un uomo. Traduzioni poetiche. Milano: Mondadori, 2010, p. 603-606.

${ }^{240}$ Carta n. ${ }^{\circ} 10$, datada de 6 de setembro de 1966.

${ }^{241}$ Carta n. ${ }^{\circ}$ 67, datada de 24 de dezembro de 1966.

${ }^{242}$ Carta n. ${ }^{\circ} 89$, datada de 14 de janeiro de 1967.

${ }^{243}$ Carta n. ${ }^{\circ} 114$, datada de 9 de fevereiro de 1967.
} 
distinta dentro do poema como um todo: "E inconicmio a ostinarmi... — donna, a quel grado ti espandi!" Após o período do meu trabalho de transcrição das cartas, Bruna encontrou outro documento datilografado com a tradução de "O mergulhador", o mesmo contendo anotações em verde feitas por ambos, quase indistintamente, se não fosse pela diferença da caligrafia de cada um. Infelizmente, esse documento não nos foi cedido para transcrição, mas supomos que se trate do texto que circulou entre os dois no mês de fevereiro de 1969. Ungaretti diz: “[...] envio-te todas as traduções feitas de Vinícius de Moraes, exceto $\underline{\text { il }}$ Tuffatore já em Tuas mãos. Não creio que Vinícius volte em breve para o Brasil. Tem intenção de estabelecer-se em Florença"; ${ }^{244}$ e continua mais adiante, naquele mesmo mês:

Tua tradução é um portento, obrigada pelos retoques. Chamo-a de Tua, porque sem os retoques, não teria a plenitude do seu significado. Espero as outras quatro revisadas. Vinícius volta dia 4 ou 5 de março, e ficará alguns dias em Roma. Vou the mostrar o resultado obtido com Tua intervenção miraculosa. ${ }^{245}$

Entre os tradutores de Ungaretti, despontam nomes como Philippe Jaccottet, Paul Celan e Ingeborg Bachmann, mas há sobretudo uma atenção especial dada a essas relações, a esses encontros, à revisão dos textos, à vivência com os tradutores. A carta em que Ungà menciona pela primeira vez a Bruna o seu amigo e tradutor Jaccottet é a mesma em que surge, também pela primeira vez, o nome de Mallarmé. O poeta francês é uma de suas grandes influências literárias da juventude, juntamente com Leopardi. ${ }^{246}$ Ungà afirma: “[...] aqui diante há um espelho embaçado com algumas rachaduras no antigo prateado. É como a minha memória, e entendo porque Mallarmé ${ }^{247}$ amava tanto estes espelhos". ${ }^{248}$ Há nas entrelinhas de suas cartas estes momentosestilhaços, clareiras, que apresentam uma completude de um possível retrato do poeta: Ungaretti observa a imagem de si entre rupturas e apagamentos.

O poeta está organizando sua próxima viagem ao Brasil e justifica, em diversas ocasiões, a necessidade de voltar à Europa para trabalhar com seu tradutor francês:

\footnotetext{
${ }^{244}$ Carta n. ${ }^{\circ} 363$, datada de 5 fevereiro 1969. Relembramos aqui o poema Soneto a Florença, de Vinícius de Moraes, porém anterior, datado 1953, "Florença... que serenidade imensa/Nos teus campos remotos, de onde surgem/Em tons de terracota e de ferrugem/Torres, cúpulas, claustros: renascença [...]" [http://www.viniciusdemoraes.com.br/pt$\mathrm{br} /$ poesia/poesias-avulsas/soneto-de-florenca, consultado em novembro de 2018].

245 Carta n. ${ }^{\circ} 368$, datada de 19 de fevereiro de 1969.

246 " [...] io rimanevo fedele a Mallarmé e a Leopardi, a Mallarmé che sentivo anche se non tutto capivo, a Leopardi che capivo un po' di più benché anche lui abbia, nel punto sublime, nla necessaria sostanza ermetica" (p. 740-741, nota introduttiva a cura di Ungaretti e Ariodante Marianni. La Vita d'un uomo: tutte le poesie).

${ }^{247}$ Sobre Mallarmé, espelhamento e uma análise de "Hérodiade", vide o artigo de Larissa Drigo Agostino na revista Sibila: "Para Mallarmé, a ficção é um método, ou seja, uma demonstração. A ficção demostra, expõe pela linguagem, que é o seu instrumento. Ela segue o método da linguagem: Le langage se réfléchissant. Isso quer dizer que a linguagem reflete algo, como um espelho, ela expõe a ficção. E ainda, ela revela algo a ser pensado, sobre o qual se deve refletir" (https://sibila.com.br/mapa-da-lingua/a-poesia-de-stephane-mallarme/12015, consultado em novembro de 2018). 248 Carta n. ${ }^{\circ}$ 89, datada de 14 de janeiro de 1967.
} 
Querida, amor, alma minha. Acredito que as datas da viagem sejam, por agora, as seguintes: partida de Nápoles dia 30 de março, chegada em Santos dia 14 de abril, volta de Santos para a segunda metade de maio. Não posso ficar mais tempo. Tenho aqui tais compromissos, e também a edição francesa, que de forma alguma posso adiar. O tempo do escritor, Jaccottet, que me traduz, é organizado com estreita margem e cometeria uma incorreção se não fosse puntual. Jaccottet è um poeta e um escritor de primeira. ${ }^{249}$

O nome de Jaccottet, poeta e tradutor suíço, responsável pelas publicações $\grave{A}$ partir du désert (1965), Innocence et mémoire (1969), assim como o prefácio da obra completa de Ungà publicada pela Gallimard com o título Vie dún homme. Poésie (1914-1970) em 1973), surge em diversas $\operatorname{cartas}^{250}$ endereçadas à amada. $\mathrm{O}$ tema constante é a publicação de sua obra na França, como adverte no começo de 1967: “[...] Em Paris em março serei forçado a ir: devo preparar o livro de ensaios a serem traduzidos que deverá publicar Gallimard. Devo fazer acordos com Jaccottet, meu tradutor, que deveria começar a trabalhar em junho", ${ }^{251}$ e insiste no dia seguinte, talvez para justificar algum desaponto de Bruna em relação ao tempo de sua permanência no Brasil: “[...] infelizmente tenho compromissos, não é uma palavra que deve me servir como um bom pretexto, Jaccottet prepara a tradução dos meus ensaios [...] preciso encontrá-lo antes para nos colocarmos de acordo sobre a escolha e o modo de interpretar as possíveis dificuldades dos escritos. É o dever. Não posso transgredi-lo". ${ }^{252} \mathrm{O}$ sentimento de responsabilidade para com a sua obra é uma constante: o poeta faz listas enumerando ou os trabalhos já entregues ou os que ainda está por terminar, textos para catálagos, traduções, publicações, reuniões e viagens. Continua falando da urgência de sua volta à Europa, e menciona, como motivo para não estender ainda mais seus dias no Brasil, novamente o seu tradutor Jaccottet nos dias 12 de fevereiro, 15 de março ${ }^{253}$ e 20 de junho, ${ }^{254}$ mas somente em julho parece conseguir colocar as mãos no manuscrito que enviará ao tradutor, com a ajuda de D'Amico, ${ }^{255}$ cujo trabalho de revisão segue por

\footnotetext{
249 Ibid.

${ }^{250}$ Cartas n. $^{\circ} 89,111,112,116,134,149,169,180,189,191,193,226,269$ e 370.

${ }^{251}$ Carta n. $^{\circ} 111$, datada de 6 de fevereiro de 1967.

252 Carta n. $^{\circ} 112$.

253 'Domani arriva Jaccottet, un ottimo scrittore, e l' unico che traduca bene dall'italiano - e con lui e Gallimard devo prendere accordi per l'edizione francese dei miei saggi. Venerdì devo tornare a Roma. Sabato e domenica ci sono le riunioni della Comunità europea degli scrittori, e ne sono il presidente, e non posso mancare." (Carta n. $\left.{ }^{\circ} 134\right)$

254 "Dunque, che cosa ho da fare? Mettere al più presto a punto la scelta dei saggi da consegnare a Jaccottet per l'edizione francese che pubblicherà Gallimard. Partecipare alla giuria dei premi letterari delle quali faccio parte. Sono tanti: Premio Sila, Premio Viareggio, Premio Strega, ecc.” (Carta n. ${ }^{\circ}$ 149)

255 "Non sono padrone di me stesso. Ora vorrebbero che andassi a Nairobi. Non ci andrò. Per la prima settimana d'agosto, D'Amico ha accettato di venire a lavorare con me al manoscritto che dovrò spedire a Jaccottet per la traduzione francese destinata a Gallimard." (Carta n. ${ }^{\circ}$ 169, datada 23 de julho de 1967)
} 
todo o mês de agosto: ${ }^{256}$ "O que faço? Prossigo meu trabalho nos textos a serem entregues a Jaccottet para a tradução francesa que sairá pela Gallimard". ${ }^{257}$ Finalmente, escreve no dia seguinte, assim como se se dirigisse ao um diário e ao mesmo tempo à amada:

D’Amico viajou; mas, com sua colabração, o trabalho para Jaccottet está pronto. Pronto é um jeito de dizer. Agora ocorre que se façam três cópias; mas já não meu trabalho, se não pelos erros que nunca faltam dos datilógrafos, que me forçam e retomar em mãos os papéis para corrigi-los. ${ }^{258}$

Em abril de 1968, faz a revisão das traduções de Jaccottet. Assim, na mesma noite em que fará uma leitura no Instituto Goethe de Roma com as traduções de Bachmann, misturando ao dever as observações do ambiente que o circunda, ele diz:

Hoje é um dia esplêndido, e de um silêncio que dá quase medo. Estou aqui, no meu quarto. Há pouco acabei de rever as últimas traduções de Jaccottet dos meus ensaios que deverão ser impressos em breve pela Gallimard na França, pela Mondadori na Itália, e muito provavelmente em alemão, e nos Estados Unidos e na Inglaterra, em duas edições em inglês. ${ }^{259}$

Com uma leitura atenta e transversal das cartas, observa-se o iter de um livro importante: seus ensaios publicados na França. A forma pela qua o poeta se endereça à amada, sempre frisando os afazeres do cotidiano, talvez para lembrar a si mesmo do que já fez e do que deve fazer, nos ajuda a percorrer minuciosamente alguns caminhos percorridos pelo próprio poeta nos últimos anos da sua vida. Quando, enfim, está em Paris para o lançamento do livro, escreve com toda euforia a Bruna: "O livro terá o sucesso que merece, e sem soberba posso dizer que merece o máximo sucesso. O recebeste? É excessivamente vivo, uma escritura belíssima, também pelo mérito de Jaccottet, que escreve como um Deus, o seu francês puríssimo". ${ }^{260}$

Nem tudo é um mar de rosas, e o risco que se corre ao abrir para o público uma longa correspondência — essa caixa de Pandora - é que os citados e envolvidos podem incendiar polêmicas e discussões a partir de algumas linhas ditas — ou melhor: escritas — num contexto privado. Foi o caso, logo após a publicação, em 2014, da correspondência entre Ungaretti e Piccioni, no volume L'allegria è il mio elemento, organizado por Silvia Zoppi

\footnotetext{
256 "Ora avrò da lavorare alla revisione dei testi da inviare a Gallimard (anzi a Jaccottet che ha da tradurli, ma molti sono tradotti, già usciti in riviste francesi). In ogni caso sono mille pagine da rileggere, e, qualche volta, da rielaborare." (Carta n. $\left.{ }^{\circ} 189\right)$.

257 Carta n. ${ }^{\circ} 191$, datada de 18 de agosto de 1967.

${ }^{258}$ Carta n. $^{\circ} 192$, datada de 19 de agosto de 1967.

259 Carta n. ${ }^{\circ} 269$, datada de 5 de abril de 1968.

${ }^{260}$ Carta n. $^{\circ} 370$, datada de 28 de fevereiro de 1969.
} 
Garampi, de uma réplica póstuma de Piero Sanavio. Entre as últimas cartas de Ungà, há esta enviada de Harvard em que o poeta escreve a Piccioni:

[...] Não podes imaginar que porcaria que me fizeram Sanavio e De Roux. Deram, em grande parte, o que havia sido traduzido para Gallimard, e para Le Seuil, por Jaccottet, poeta e tradutor perfeito, - e o direito de autor o proibia, em traduções que são horríveis. Terei de encontrar o representate da Siae no Gens de lettres e ver com Gallimard como impedir a saída deste horror. ${ }^{261}$

Trata-se do mesmo volume da revista L'Herne muitas vezes citado por Ungaretti nas cartas a Bruna. Entre os poemas e prosas traduzidos, há diversos depoimentos e retratos do autor. Há o plano de levar este volume a Estocolmo para presentear alguns dos membros da Academia Sueca, numa viagem em que seria acompanhado pela esposa de Piero Sanavio, Annuska Palma, tradutora da língua sueca. No momento em que Ungaretti escreve a Piccioni, a revista já havia sido publicada, de forma que a sua reclamação parece não corresponder a quaisquer possibilidades reais de "impedir a saída" do volume.

Numa réplica pública, ${ }^{262}$ Sanavio se defende, dizendo que Jaccottet havia se recusado a participar da edição e que as traduções dos poemas de Ungaretti do livro Dialogo eram suas, de Sanavio, e a tradução dos poemas de Bruna, sempre do livro Dialogo, eram de Yvonne Caroutch, a mesma tradutora dos poemas selecionados de Il Porto Sepolto e da prosa “Cahier Egyptien”, enquanto as demais prosas ficaram por conta de Moenis Taha Hussein (tradutor escolhido por Ungaretti). ${ }^{263}$ Segundo Piero Sanavio, o que houve foi uma mudança — uma edição — dos poemas de Bruna em sua versão francesa, por parte de Ungaretti. Sanavio admite que a carta de Ungaretti parece funcionar como um caixa de ressonância em relação à carta recebida anteriormente por seu interlocutor, Piccioni, como se espelhasse alguma reclamação.

${ }^{261}$ UNGARETTI, Giuseppe. L’allegria è il mio elemento. Org. Silvia Zoppi Garampi. Milano: Mondadori, 2013, p. 352.

262 SANAVIO, Piero. “Sulla lettera di Giuseppe Ungaretti”. Reti di Dedalus, rivista del sindicato degli scrittori. http://www.retididedalus.it/Archivi/2014/dicembre/LUOGO_COMUNE/4_querelle/querelle.pdf. [consultado 5/01/2015 e 8/11/2018]

263 "Le traduzioni del Porto Sepolto e della prosa Cahier Egyptien erano opera della poetessa Yvonne Caroutch, che svolgeva quel ruolo presso les Editions du Seuil; quelle delle altre prose, di Moenis Taha Hussein (figlio dell'omonimo egiziano, di lingua madre francese e scelto da Ungaretti); per Dialogo le versioni erano mie e di Caroutch - Jaccottet avendo declinato l'invito. Come è noto Dialogo consiste di due sezioni - una di Ungaretti, l'altra della sua musa dell'epoca Bruna Bianco. Le mie traduzioni sono della parte di Ungaretti; quelle di Caroutch delle poesie di Bianco. Prima di darlo a stampa, il testo di tutte le traduzioni fu sottoposto a Ungaretti, il cui francese, come nel mio caso peraltro, era prima lingua. In inchiostro verde, Ungaretti corresse le versioni riga per riga, il volume passato a stampa soltanto dopo che il poeta ebbe dato il suo "bon a tirer." Per Dialogo e l'intervista, di tutto questo esiste testimonianza - e sono gli originali dei testi tradotti con le correzioni del poeta. Raccolti in un volumetto rilegato dal titolo Ungaretti, quei manoscritti sono reperibili, insieme alla corrispondenza del poeta, nel costituendo "Fondo Piero Sanavio" presso la Biblioteca Universitaria dell'Universita di Padova. Quanto agli originali delle traduzioni delle prose, immagino siano reperibili negli archivi de L'Herne." (Ibid.) 
Sanavio surge, assim como sua esposa, noutros momentos nas cartas, sempre de forma muito carinhosa, nas palavras de Ungaretti, ainda que com uma pitada de fofoca, tom presente em vários episódios desta troca íntima de confidências entre o poeta e sua jovem interlocutora. Tramas e intrigas desse tipo nos levam a correr o risco de perdermos nosso caminho analítico, de nos emaranharmos nos meandros labirínticos dos desacordos e desafetos, ou simples comentários que ocorrem em qualquer troca íntima, mas que nesse contexto podem ser observados com maior atenção e sob uma lupa. É preciso tomar alguma distância tanto do que há de fofoca nas cartas como também das polêmicas suscitadas a partir delas. Mexer num acervo tão íntimo é também mexer num vespeiro.

Porém, há certo mérito até nessas entrelinhas, nesse tipo de texto menor. Ao lermos em primeira mão estas cartas, não só desfrutamos de uma observação privilegiada do pensamento de um autor, mas também entramos em contato com suas diversas facetas. Há a pessoa, com todas as suas virtudes e os seus vícios, para além do filtro literário, e há as contradições e os entrelaçamentos de eventos cincunscritos no momento específico no mundo e na vida do autor. Enfim, como diria Gustave Lanson, citado por Brigitte Diaz: “[...] por trás das teorias, os homens, e sob o encadeamento inflexível das ideias, a imensa ondulação e a efervescência confusa da vida". ${ }^{264}$ A respeito das cartas a Bruna, o único comentário tecido por Sanavio foi “[...] sem comentários sobre o voyeurismo da publicação por parte da Mondadori", ${ }^{265}$

Sanavio suspeita que a reclamação de Ungà estava relacionada com o não pagamento dos direitos por parte da revista, responsabilidade atribuída a Sanavio quando esse já não mais era responsável pelo trabalho. Sanavio afirma que se "não foi feito [o pagamento] as responsabilidades estão todas dentro das estruturas específicas da Organização. Também neste caso os documentos, consultáveis somente por pedido escrito, estão no Fundo, citado, da Biblioteca". ${ }^{266}$ A leitura desses desacordos e dessas polêmicas servem não tanto para tecermos um histórico de fofocas literárias, mas sim para compreendermos o quão complexos são os procedimentos de organização de um volume, seja de poemas ou de traduções, da reunião de tradutores, colaboradores. Podemos, dessa forma, olhar para as publicações acrescentando esse filtro de complexidade real dos processos envolvidos. Nesse trabalho, tentamos também repensar a figura do tradutor enquanto organizador de um arquivo e enquanto editor das cartas, e tais polêmicas jogam alguma luz que nos permite

${ }^{264}$ LANSON, Gustave. Sur la littérature épistolaire, introdução a Choix de lettres du XVII siècle, Paris: Hachette, 1895, in DIAZ, Brigitte. O gênero epistolar ou o pensamento nômade. São Paulo: Edusp, 2016, p.11.

265 SANAVIO, Piero. "Una corrispondenza: Dialogo Ungaretti- Bianco". Revista Malacoda. https://malacoda4.webnode.it/una-corrispondenza-dialogo-ungaretti-bianco/ [consultado 14/04/2019]

266 Ibid., tradução nossa. 
entender as dificuldades e os desafios inerentes a todo o processo. Enfim, não é somente, como vimos com Lejeune, o texto e o autor que, de alguma forma, se misturam — não podemos prescindir do elemento biográfico do autor, mas tampouco podemos dobrar o texto ao biográfico - pois a mesma lógica se aplica à tradução e organização de um volume. O que dizer sobre um volume como o de L'Herne, em que há depoimentos de Quasimodo e Montale sobre Ungaretti, sob a luz do que se lê no foro privado sobre esses autores, na consideração de Ungaretti?

Paul Celan e Ingeborg Bachmann também traduziram textos distintos de Ungaretti em momentos distintos. Nessas cartas, o poeta cita Bachmann com maior frequência, enquanto Celan surge apenas uma única vez. Em janeiro de 1967, Ungà apresenta sua tradutora a Bruna: “Alma minha, voltei de Catânia. Chegamos de avião ao meio dia. Depois fui à casa. Depois ao Buco, onde almocei com Ingeborg Bachmann. É minha tradutora alemã. Uma das primeiras escritoras alemãs. Talvez o maior poeta alemão de hoje." ${ }^{267}$ Austríaca de Klagenfurt, parte do Grupo 47, ${ }^{268}$ Bachmann viveu muitos anos em Roma, onde também faleceu em circustâncias trágicas em meados dos anos de 1970. Em 1961, já havia publicado suas versões poéticas de Ungá, sobre as quais escreve a Paul Celan: ${ }^{269}$ " [...] dovrai essere ancora una volta indulgente con i miei esperimenti di traduzione da Ungaretti, che presto potrò inviarti. Foglio dopo foglio..." ${ }^{270}$ No verão do mesmo ano, ela envia a Celan as traduções publicadas em Gedichte. ${ }^{271}$ Celan também traduz Ungaretti, mas isso apenas em 1968. Bachmann publica suas traduções de Ungaretti antes de se estabelecer em Roma, pois só em 1965 é que adota de forma permanente a capital italiana. Federico $\mathrm{Dal} \mathrm{Bo}{ }^{272}$ oferece um estudo comparativo interessante das traduções de Bachmann e de Celan de um mesmo poema de Ungaretti, "Cantetto senza parole", parte da produção mais tardia, contido no livro Il Taccuino del Vecchio, e observa que a antologia curada por Bachmann no começo dos anos de 1960, após sua primeira permanência na Itália e suas primeiras traduções...

[...] parece inspirada principalmente pela vontade descritiva de oferecer um panorama mais representativo possível da obra do poeta italiano, até então vinculado a uma interpretação, por grande parte da crítica

\footnotetext{
267 Carta n. ${ }^{\circ} 79$.

268 O Grupo 47 (al. Gruppe 47) era um grupo informal de autores e críticos alemães que tinha como objetivo revitalizar a literatura alemã de pós-guerra. Entre os integrantes Ingeborg Bachmann, Heinrich Böll, Paul Celan.

${ }^{269}$ BACHMANN, Ingeborg. CELAN, Paul. Troviamo le parole. Lettere 1948-1973. Roma: Nottetempo, 2010.

270 Ibid., p.184.

271 As traduções de Bachmann são de 1961 e as de Celan de 1968: UNGARETTI, Giuseppe. "Kleines Lied ohne

Worte”, in Gedichte, tradução alemã de Ingeborg Bachmann. Frankfurt Am Main: Suhrkamp, 1961, pp. 142-145. UNGARETTI, Giuseppe, "Kleiner Gesag ohne Worte", in Das Verheißene Land, tradução alemã de Paul Celan, Frankfurt Am Main: Suhrkamp, 1968, pp. 116-119.

272 DAL BO, Federico. “Traduzione come poesia: Bachmann e Celan interpreti di Ungaretti”. In Traduzione e poesia nell'Europa del Novecento, a cura di Anna Dolfi. Roma: Bulzoni, 2004, pp. 447-470.
} 
alemã, muito influenciada pelo esforço de Ungaretti de reformular o petrarchismo para os tempos modernos. ${ }^{273}$

Em seu prefácio, a tradutora e poeta afirma:

[...] para esta antologia, foram traduzidos uns quarenta poemas do primeiro livro, L'Allegria, portanto mais do que da produção tardia de Ungaretti. De fato, nos primeiros poemas encontra-se já aqueles tons e gestos que deveríamos reconhecer imediatamente, todas as novas possibilidades expressivas que Ungaretti descobriu em sua língua. ${ }^{274}$

Pela análise contrastiva de Dal Bo, poderíamos dizer que há alguma irmandade entre Bachmann e Ungaretti na forma de olhar para o poema e traduzi-lo, pois "[...] este cuidado e a mesma contiguidade à língua poética do original mostram de novo a intenção (de Bachmann) em renunciar a fundar o exercício poético num efeito de língua dado pela exentricidade das escolhas sintáticas ou lexicais", 275 uma busca por clareza que não exclua o mistério da palavra. Ainda segundo Dal Bo, Bachmann afirma sobre sua própria poética: “[...] com os meus poemas quero ser compreensível, e gostaria de sê-lo sempre mais, mas isto não exclui nem a sutileza, nem, em alguns momentos, a dificuldade de compreensão". ${ }^{276}$ Há uma conduta coerente entre o que a autora diz sobre sua própria poesia e sua escolha em publicar essa antologia de traduções, pois “[...] assume um significado mais profundo, que não se contenta com as quase banais justificações filantrópicas de querer que Ungaretti seja conhecido"277 pelos leitores alemães. Para Dal Bo, há uma hipótese de transparência nas traduções de Bachmann, pois a autora teria “[...] tentando interpretar cada linha do poema, introduzindo só quando necessário, novos complementos, pronomes e conjunções para explicar a compisição", ${ }^{278}$ na tentativa de preservar um elemento sóbrio de uma língua lírica que ela mesma sentia como distante da língua tradicional "[...] opulenta e decorativa da poesia italiana". ${ }^{279}$ Se, por um lado Ungaretti, enquanto tradutor, parece mais disposto a dobrar um verso para que se encaixe perfeitamente na língua de chegada - o italiano - o que o aproxima à Bachmann, no trabalho de perlaboração do verso traduzido, é o uso da tradução como um momento de prática da própria poética. Ao traduzir Ungaretti, a poeta não só se preocupa em manter "[...] to tom imediato e a graça das composições", mas também, segundo Dal Bo, subterraneamente ao mesmo

\footnotetext{
273 Ibid, p. 452.

274 BACHMANN, Ingeborg. Nachwort, in G. Ungaretti, Gedichte. Apud DAL BO, F. Op. cit., p. 452.

275 DAL BO, Federico. In Traduzione e poesia nell'Europa del Novecento, a cura di Anna Dolfi. Roma: Bulzoni, 2004. p. 457.

276 BACHMANN, Ingeborg. In cerca di frasei vere. Tr. it, Roma-Bari: Laterza, 1989, p.107. Apud DAL BO, Fede-

rico. In Traduzione e poesia dell'Europa del Novecento, p. 457.

277 Ibid.

278 Ibid.

${ }^{279}$ Ibid. p. 458.
} 
imperativo literário que guia a própria poeta em sua produção, ou seja: "[...] tentar criar uma obra de arte em cada frase". ${ }^{280}$

Pelas breves descrições de Ungaretti, parece ter existido uma relação de literatura e confidência entre os dois poetas. Toda vez que menciona um encontro com Bachmann pra Bruna, o poeta está muito atento em frisar: minha tradutora alemã. Por um lado, parece estar atento a não provocar ciúmes em Bruna, por outro lado, parece incitá-lo: “[...] verás no [jornal $L a$ ] Stampa que, após a entrega do prêmio, abracei-a e beijei-a. É um gesto fraterno. Só tu, meu amor, se me beijas, até mesmo só por carta, me enlouqueces. É só o teu beijo, para mim [...]", ${ }^{281}$ descrevendo assim uma cena da qual Bruna jamais teria tido conhecimento, pois, estando no Brasil, não tinha acesso aos jornais italianos. Bachmann surge novamente como quem podia ter contado, no dia seguinte do almoço com o Ungà, para o escritor francês e amigo comum, Jean-Edern Haillen, que Ungà passava várias horas, todos os dias, no Café Greco para "écrire votre lettre" 282 à amada. Uma vez que alguém habitava o seu círculo de afeto, transitava indistintamente entre a colaboração literária e a vida anímica. Esse parece ter sido o caso de Ingeborg Bachmann na vida do poeta.

Encontram-se também em Londres, durante o festival em que estarão presentes Allen Ginsberg, Anne Sexton, Ted Hughes e vários outros poetas. Numa das cartas, Ungaretti diz que irá a Chelsea, especificamente a King's Road, para assistir ao desfile das jovens em mini-saia e:

Ingeborgh Bachmann virá conosco, minha tradutora alemã. Está feliz. Finalmente reencontrou um amigo. [...] Encontram-se secretamente. Está aqui. Nenhuma outra pessoa o vê, só ela. Ninguém nunca o viu. Nem o teu apaixonado que compartilha uma relação de muito afeto com a Bachmann. ${ }^{283}$

Ungà agrega mundos e afetos ao seu redor, uma ponte entre artistas, escritores, poetas e intelectuais. Descreve um almoço, como um pequeno fato de crônica, mas nessa leitura nos apresenta um pouco mais desse ambiente múltiplo e rico no qual se insere o seu dia a dia romano: “[...] quinta-feira almoço com Chico [Buarque] e a esposa, com Leone e a Fürstenberg, ${ }^{284} \mathrm{com}$ a Bachmann, um dos dois maiores poetas alemães de hoje, junto a Celan: são os meus dois tradutores alemães, com Netto do Jornal do Brasil, etc., etc.,

\footnotetext{
280 BACHMANN, Ingeborg. In cerca di frasi vere, tr. it., Roma-Bari: Laterza, 1989, p. 179. Apud DAL BO, Federico, Traduzione e poesia dell'Europa del Novecento, p. 457.

281 Carta n. ${ }^{\circ} 79$.

282 Carta n. $^{\circ} 80$.

283 Carta n. ${ }^{\circ} 166$.

${ }^{284}$ Ira Fürstenberg (1940—), atriz ítalo-alemã.
} 
etc.”. ${ }^{285}$ Traduzir Ungaretti, para Bachmann, também marca seu momento de transição entre a poesia e a prosa. Segundo a pesquisadora Enza Damiano, da Universidade L'Orientale di Napoli, ${ }^{286}$ a tradução, assume "um valor simbólico" para Bachmann e "se torna parte integrante do processo de pesquisa que sempre animou a reflexão da escritora sobre as possibilidades [...] e os limites, da linguagem", ${ }^{287}$ é nesse campo entre línguas que "a palavra pode viver plenamente sua condição fronteiriça entre o dizível e o indizível [...] lugar de sombra e luz ao mesmo tempo, lacuna e limiar, espaço de confrontação com o Outro, em que algo novo pode continuar a surgir". ${ }^{288}$ Mais uma vez, há um entrelaçamento entre a visão poética de Bachmann e de Ungaretti, pois, entre as razões ungarettianas da poesia, não podemos esquecer o que o autor denomina como mistério, ou segredo, esta indeterminação que é também como um estar entre, uma força motriz em que "as palavras estão predestinadas por uma atração de raízes abissais". ${ }^{289}$

O encontro entre Ungaretti e Bachmann se faz antes no sentimento compartilhado de um aspecto estrangeiro que carregam ambos, no começo da vida, mas talvez em toda a existência, cujo aterramento se deu sobretudo através da língua. Ungaretti, na introdução à sua obra completa, diz: “Conoscevo l'Italia soprattutto perché parlavo l'italiano, perché tuto ciò che m'era caro era nella mia lingua. Non sono cose che si spiegano, la lingua m'era un legame che mi portava fino alla culla dei miei nella lontananza dei tempi" ${ }^{290}$ A língua como algo herdado desde o berço de seus pais. Filho de migrantes da região de Lucca estabelecidos em Alexandria, no Egito, a primeira condição que vive Ungaretti é a de estrangeiro, sentimento compartilhado por Bachmann que, em nota biografica, revela: “[...] vivi minha juventude em Caríntia ${ }^{291}$, no Sul, próximo ao confim [...] E a casa [...] preserva ainda um nome que sabe de estrangeiro". ${ }^{292}$ Além do olhar estrangeiro para si e para o mundo, o trabalho de inovação contemplado pela criação poética, pela contínua perlaboração em torno da língua, da palavra e da forma, são os elos que ligam os dois poetas. Segundo Damiano, no ensaio em que estuda as traduções de Bachmann dos versos escolhidos de Ungà, Ungaretti quer que as suas mudanças anímicas correspondam também às

\footnotetext{
285 Carta n. ${ }^{\circ} 371$.

286 DAMIANO, Enza. "Due lingue in una voce sola. Ingeborg Bachmann traduce Giuseppe Ungaretti" (https://www.academia.edu/5688154/Due_lingue_in_una_voce_sola_Ingeborg_Bachmann_traduce_Giuseppe_Ungaretti, consultado em novembro de 2018).

287 Ibid., p. 1.

288 Ibid., p. 2.

289 UNGARET'TI, Giuseppe. Vita d'un uomo. Saggi e Interventi. Op. cit., p. 580.

290 UNGARETTI, Giuseppe. Vita d'un uomo. Tutte le poesie. Op. cit., p. 742.

${ }^{291}$ Caríntia é um estado da Áustria meridional.

292 DAMIANO, Enza. "Due lingue in una voce sola. Ingeborg Bachmann traduce Giuseppe Ungaretti”, p. 3 (https://www.academia.edu/5688154/Due_lingue_in_una_voce_sola_Ingeborg_Bachmann_traduce_Giuseppe_Ungaretti, consultado em novembro de 2018).
} 
mudanças na forma do poema, e dessa forma se inscreve a tentativa de Bachmann: correponder à letra em suas traduções. A expressão "corresponder à letra" não passa desapercebida para nenhum estudioso da tradução, pois há uma associação imediata com o trabalho de Antoine Berman. Mas como poderíamos ligar o pensamento do tradutor e pesquisador francês aos trabalhos de tradução operados por Bachmann e Ungaretti?

Seria oporturno aproximarmos as considerações dos três no sentido de expandir nossa compreensão da prática tradutória presente na obra de Ungaretti, do vínculo dela com a criação, da relação do poeta com seus tradutores, mas também como um gesto de reflexão sobre o nosso próprio empenho em traduzir e anotar suas missivas a Bruna. Em A tradução e a letra ou o albergue do longíquo, ${ }^{293}$ Berman fala sobre a dimensão da tradução como experiência, algo que a distingue das atribuições que lhe foram dadas anteriormente, e a tradução como experiência é algo que atravessa tanto a prática de Ungà quanto a de Bachmann. Berman diz:

Assim é a tradução: experiência. Experiência das obras e do ser-obra, das línguas e do ser-língua. Experiência, ao mesmo tempo, dela mesma, da sua essência. Em outras palavras, no ato de traduzir está presente um certo saber, um saber sui generis. A tradução não é nem uma sub-literatura (como acreditava-se no século XVI), nem uma sub-crítica (como acreditava-se no século XIX). Também não é uma lingüística ou uma poética aplicadas (como acredita-se no século XX). A tradução é sujeito e objeto de um saber próprio. Mas a tradução (quase) nunca considerou sua experiência como uma palavra inteira e autônoma, como o fez (ao menos desde o Romantismo) a literatura. ${ }^{294}$

O título de Berman condensa sua visão de tradução como uma acolhida da "letra" estrangeira na língua materna, tradução como albergue, como lugar de abrigo ao forasteiro, um lugar em que este pode sentir-se em casa sendo outro, um lugar ao mesmo tempo próximo e distante. Para Berman, a tradução da letra é o que busca encontrar algo que não seja necessariamente normatizado na língua de chegada, introduzir aí a língua estrangeira e seu dizer, pois é neste lugar em que se aceita o Outro - abrigar o longíquo na língua materna, na língua de chegada. Observamos que muitas vezes Ungaretti faz o contrário, dobrando o verso de partida à língua de chegada — o italiano. Mas há também a preservação de palavras estrangeiras presentes nas traduções dos poemas brasileiros e, mais do que isso, há a incorporação do longíquo em seus próprios versos, quando, a partir da sua experiência como tradutor de poetas brasileiros, escreve o poema "Semantica", transitando pela experiência do estrangeiro e acrescentando ironia e crítica aos seus pares. Vejamos: "Come

\footnotetext{
293 BERMAN, Antoine. A tradução e a letra ou o albergue do longíquo. Rio de Janeiro: 7Letras, 2007.
}

${ }^{294}$ Ibid., p. 18. 
dovunque in Amazzonia, qua/ L'angìco abbonda, e già scoprirsi vedi/ Alcuni piedi di sapindo,/ Il libarò dei Guaranì;/ E, di rado, di qui o di là,/ I cautsciò si adunano in boschetti, [...]". ${ }^{295}$ O poema "Semantica", presente no livro Un Grido e Paesaggi, nasce como uma resposta às traduções feitas de seis poemas de Oswald de Andrade, e a alusão a esses versos surge mais uma vez, alguns anos mais tarde, em sua introdução à edição italiana de Memorie sentimentali di Giovanni Miramare (Milão: Feltrinelli, 1970). O verso-refrão no poema "Monologhetto", que abre Un grido e paesaggi, pode ser lido como citando uma canção "ironia, ironia/ era só o que dizia", mas revela também algo presente no poeta, sua pitada de ironia, como quando diz "não sou o poeta da alegria?" numa de suas últimas cartas a Piccioni, ou quando escreve a Murilo Mendes sobre esse poema: “'Semantica' não é outra coisa se não um jogo para tirar um sarro dos amadores, da nossa casa, de palavras extravagantes, e também para rir, mas sem a maldade, dos etimologistas. Trata-se de um brincadeira, nada mais" ${ }^{\$ 296}$. Para criar um jogo com as palavras, para poder se servir da ironia na criação com um gesto duplo - por um lado de crítica e por outro de incorporação de certos elementos à própria língua — podemos talvez falar de um cruzamento entre a letra e a intenção antropofágica quando Ungaretti aborda a tradução.

Explorando convergências entre poesia e tradução em Ungaretti, Wataghin sugere que um dos princípios que devem ser destacados como ponto de partida para a prática de tradução é o espírito de máxima fidelidade à letra, pois, conforme diz Ungà, " [...] procurar a verdade fora da letra é um desgaste inútill". ${ }^{297}$ Wataghin continua: "[...] a tradução pode ser, para cada poeta, 'um exercício sem comparação para treinar a mão', porque não há outra maneira, tão eficaz, para tocar ao vivo os problemas técnicos, ou de inspiração, do que enfrentá-los de um poeta para outro, ${ }^{298}$ não há outra leitura tão profunda e ativa quanto àquela constituída pela tradução poética". ${ }^{299}$ Tradução como a leitura mais profunda que possa ser feita ou, como diz o poeta, a possibilidade de treinar a mão e lidar diretamente tanto com problemas técnicos do verso quanto com a inspiração. Wataghin, ao escrever sobre a relação de Ungaretti com a prática da tradução, traz os significados de uma leitura profunda e ativa, mantendo, porém, o que o poeta denomina como respeito à letra, ou seja, fazer uma leitura que possa "manter na mira [...] o respeito à letra, palavra por palavra,

295 UNGARETTI, Giuseppe. Vita d'un uomo. Tutte le poesie. Milano: Mondadori, 2009, p. 309.

296 STEGAGNO PICCHIO, citada em nota ao poema em Ibid., p. 1001.

297 UNGARETTI, Giusppe. Da Góngora a Mallarmè. Milano: Arnoldo Mondadori, 1948, p.19, tradução nossa, cit.

WATAGHIN, Lucia. Giuseppe Ungaretti: idee su poesia e traduzione. La traduzione saggi e documenti II, Roma: Zecca dello Stato, 1995, p. 184.

298 Nota de Lucia Wataghin, nota de Ungaretti na obra 40 Sonetti di Shakespeare, op. cit. p. 9, tradução nossa.

299 WATAGHIN, Lucia. Giuseppe Ungaretti: idee su poesia e traduzione. La traduzione saggi e documenti II,

Roma: Zecca dello Stato, 1995, p. 184, tradução nossa. 
do significado original", ${ }^{300}$ e que não se deixe seduzir somente pelos clarões do poder fantástico das palavras, mas que seja exata no sentindo, em sua substância psicológica. ${ }^{301}$

$\mathrm{O}$ ato de traduzir, para Ungaretti, abarca por um lado alguma convergência com a ideia de Jakobson sobre a equivalência dos efeitos, ${ }^{302}$ por outro lado a materialidade da letra, num sentido bermaniano. Na introdução à sua tradução dos sonetos de Shakespeare, Ungaretti resume: "Eu sonhava uma poesia onde o segredo da alma, nem traída nem falseada pelos impulsos, se conciliasse com uma extrema sabedoria do discurso". ${ }^{303}$ Vejamos outros comentários que acompanham a introdução à tradução dos sonetos de Shakespeare para pensar o modo pelo qual o poeta enfrenta o tensionamento entre equivalência de efeitos e fidelidade à letra. Após um longo período em que havia deixado de lado essas traduções, durante a sua permanência no Brasil, Ungaretti volta à elas e descreve assim o processo: “[...] Me perguntava se não era presuntuoso obstinar-me a transferir de uma língua a outra com alguma precisão de conteúdo poético", ${ }^{304}$ e continua descrevendo as dificuldades próprias do par de idiomas inglês-italiano, pois “ $[\ldots]$ no som era abusrdo não deixar cada uma [palavra] seguir o próprio verso, em línguas tão distintas", ${ }^{305}$ e enfim justifica a alteração do número de sílabas dos versos traduzidos, mantendo uma proporção a partir da contagem média na língua inglesa e italiana, aumentando de 11 para 16 o número de sílabas. Ungà se pergunta e responde: "Existirá, para chegar à perfeição literal, uma regra? Nenhuma". ${ }^{306}$ Aponta, porém, o seu caminho para "[...] obter o efeito imposto por todo o soneto [...]", uma das questões que levanta é a dificiuldade em verter a expressão tongue-tied sem cair na descrição literal ou usar um vocabulo "blando e pudico, como outro já fez"; por fim revela “neste [poema, Soneto CXL], não poderia me limitar senão a declarar que, após consultar $[\ldots]$ as traduções existentes, tentei $[\ldots]$ me ater sempre àquele modo que não removesse do autor, o direto, segredo contato". 307 Há algo nas colocações de Ungaretti na reflexão desse prefácio que nos remete ao que Berman descreve como a carnalidade do texto: “[...] fidelidade e exatidão se reportam à literalidade carnal do texto. O fim

300 UNGARETTI, Giuseppe. Vita d'un uomo. Saggi e Interventi. Milano: Mondadori, p. 571. Apud WATAGHIN, Lucia. Op. cit, 1995, p. 185.

${ }^{301}$ Combinação de citações de Ungaretti inseridas por Wataghin em seu texto e reelaboradas no parágrafo para completar o sentido da citação. WATAGHIN, Lucia. Op. cit, 1995, p. 1851.

302 Jakobson propõe que, no lugar de se traduzir palavra por palavra, a tradução tenha por objetivo "alcançar a totalidade da informação conceitual contida no original” (JAKOBSON, 1988, p. 67). Segundo o linguista, a principal preocupação numa tradução deve ser buscar a "equivalência na diferença" (JAKOBSON, 1988, p. 65). JAKOBSON, Roman. "Aspectos linguísticos da tradução". In Linguística e Comuinicação. Tradução de Izidoro Blinkstein e José Paulo. São Paulo: Editora Cultrix, 1988, p. 63-72.

303 UNGARETTI, Giusppe. Vita d'un uomo. Traduzioni Poetiche. Op. cit., p. 131, tradução nossa.

304 UNGARETTTI, Giusppe. Ibid., p. 132, tradução nossa.

305 Ibid.

306 UNGARETTI, Giusppe. Vita d'un uomo. Traduzioni Poetiche. Op. cit, p. 133, tradução nossa.

$307 \mathrm{Ibid}$, todas as citações do trecho que compõe esse parágrafo são traduções nossas. 
da tradução, enquanto objetivo ético, é acolher na língua materna esta literalidade. Pois é nela que a obra desenvolve sua falância, [...] e realiza sua manifestação do mundo". ${ }^{308}$

A função, assim como endereçamento da tradução, é o que impõe a diferença quando analisamos os métodos adotados por Ungaretti. Se, por um lado, ao traduzir Shakespeare, ele se coloca dizendo que todo esforço de tradução fora da letra é um esforço perdido, por outro lado, podemos retomar suas traduções dedicadas a Bruna nos primeiros meses da correspondência. A função era estar próximo à sua amada, traduzir então como um pretexto para criar. Se observarmos o trabalho de tradução enfrentado no capítulo três, estas transcriações estariam no espectro oposto ao dos critérios de Berman, pois àquelas corresponderiam à crítica do autor francês a hipertextualidade na tradução, ou seja, aquela abordagem em que a tradução pode ser confundida e misturada com outras formas de transposição literária: a imitação, a paródia, a adaptação, o pastiche, o plágio.

Enfim, nessas cartas endereçadas a Bruna, também podemos abrir um leque de correspondências e hipertextualidades no campo da reflexão sobre a tradução. Seja comentando seu convívio e sua relação com seus tradutores, seja traduzindo junto à amada os poemas de Vinícius de Moraes.

\subsubsection{O Barroco}

A vínculo de Ungaretti com o Barroco é reconhecidamente importante para compreender sua obra. Nossa intenção, nesta tese, não é elaborar uma discussão profunda sobre o tema, já que não seria possível fazê-lo num espaço tão reduzido além de fugir ao escopo deste estudo. O que desejamos pinçar aqui é como e em que contexto a questão surge nas cartas endereçadas a Bruna. Para chegarmos a este ponto faremos antes uma breve introdução sobre a relação de Ungaretti com o Barroco.

A questão do Barroco é um experiência original, ativa e viva na obra de Ungaretti enquanto poeta, teórico, ensaísta, intérprete da arte e tradutor. Sua ligação com o Barroco é um elo com o pasado que funciona como artifício para pensar o seu presente, para pensar o século XX.

Mesmo partindo de uma perspectiva de inserção no percurso de estudos italianistas, nos quais não se questionaria o conceito de barroco, é importante aqui delimitarmos algumas questões. Primeiro, qual uso faz Ungaretti do barroco para repensar suas questões e sua poética, de que forma para o poeta a vinda ao Brasil acentua essa busca e provê algumas

308 BERMAN, Antoine. O Albergue do longínquo. Op. cit, p. 71. 
respostas aos seus anseios, segundo citamos que, ao tratarmos dessa questão a partir da perspectiva de pesquisa do Brasil, em especial da Universidade de São Paulo, não podemos deixar de glossar alguns dos parâmetros levantados e questionados por João Adolfo Hansen. Em particular, o que o pesquisador propõe como reconstituição dos códigos bibliográficos, dos códigos retóricos-poéticos e dos condicionamentos materiais e institucionais das representações luso-brasileiras do século XVII, que não necessitam da noção de "barroco”, para Hansen “dedutiva”, que classifica representações específicas com perspectiva universalizante das categorias críticas, algo que seguiria o que autor denomina "psicologia idealista". Partindo desta perspectiva, a análise do barroco brasileiro, a partir do olhar de Ungaretti, seria quase a visão de algo imaginado. Para Hansen:

Para que a definição e o uso do termo fossem pelo menos aceitáveis, seria necessário que características ditas "barrocas" especificassem todas as obras de uma série determinada e apenas a elas; no entanto, as séries classificadas como "barrocas" são bastante diversas e diferentes de lugar para lugar, de autor para autor, e, principalmente, de uma arte para outra e mesmo de obras para obras de um mesmo autor, de modo que características formais propostas como específicas de "barroco", quando a noção se aplica às representações do século XVII, não passam de generalidades formuladas como deduções e analogias — informalidade, irracionalismo, pictórico, fusionismo, contraste, desproporção, deformação, acúmulo, excesso, exuberância, dinamismo, incongruência, dualidade, sentido dilemático, gosto pelas oposições, angústia, jogo de palavras, niilismo temático, horror do vácuo - que explicitam mais as disposições teórico-ideológicas dos lugares institucionais que as aplicam que propriamente a estrutura, a função e o valor históricos dos objetos a que são aplicadas, na medida mesma em que, sendo genéricas, como resultados de esquemas universalizados a-criticamente sem fundamentação empírica, também poderiam ser aplicadas a qualquer outra arte de qualquer outro tempo. ${ }^{309}$

Se para Hansen a transposição de diversos barrocos, desconjuntados de seu contexto histórico, poderia ser "plausível em termos heurísticos", resultaria em algo "anacrônico, em termos históricos". 310 Podemos pensar que o esforço ungarettiano é justamente de cunho heurístico, e que a apropriação de aproximação do barroco por parte do poeta nascido em Alexandria seja justamente algo que se presta a ser fonte de inspiração e observação para a própria obra. ${ }^{311}$

\footnotetext{
${ }^{309}$ HANSEN, J. A. Barroco, neobarroco e outras ruínas. Teresa, n. 2, p. 14, 8 dez. 2001, grifo nosso. 310 HANSEN, J. A. Op. cit., p. 21.

311 Não é possível explorar de forma mais profunda essa questão dentro desta tese, pois o foco de nossa pesquisa é outro, mas sem dúvida é um argumento que gostaríamos de aprofundar no futuro, ou seja, se para Ungaretti o Barroco é tão fundamental e sua apropriação e junção da arte barroca romana à natureza brasileira cria certo sustento para sua poética, de que forma isso poderia ser repensado a partir da perspectiva apresentada por Hansen em, por exemplo, "Barroco, neobarroco e outras ruínas"? Na página 15 do texto citado, em nota, Hansen esclarece as apropriações do "barroco" e "neobarroco" nas práticas artísticas contemporâneas. Trazemos aqui um trecho da nota: "Usos poéticos
} 
O Barroco inquieto de Ungaretti é o que carrega a qualidade de choque, de novidade, de uma invenção violenta, algo que o poeta identifica na história da cultura, na estética e que se entrelaça com sua pesquisa sobre a linguagem - um artifício, uma lente para novas descobertas e observações. Neste sentido a passagem de Ungaretti pelo Brasil, segundo o próprio, serviu como síntese desta busca:

[no Brasil] conheci de uma maneira novíssima a relação entre memória e inocência que a minha poesia sempre teve alvo conciliar [...] devo ao Brasil se entendi o barroco e o porquê entre memória e inocência, entre natureza e razão o encontro tivesse de se manifestar sempre violento. ${ }^{312}$

O atravessamento barroco para Ungaretti tem muitos caminhos, da arquitetura à pintura, da escultura à música, da poesia ao pensamento, sua Roma barroca que Michelangelo prevê, o que observa como conflito e violência na natureza enquanto vive no Brasil, seu amor pela arte de Borromini, um de seus favorito, mas também Rembrandt, o pensamento de Pascal, a palavra de Racine, Góngora, Shakespeare até a luz explosiva de Caravaggio.

A relação de Ungà com o século XVII é tratada exaustivamente por Daniela Baroncini $^{313}$ no livro Ungaretti Barocco, no qual a pesqusiadora também se esforça por enquadrar a reflexão do poeta nos movimentos de neobarroco europeu. Segundo Baroncini, “a sintonia íntima”,314 do Barroco com a “atormentada sensibilidade contemporânea” se cruzaria em diversos pontos, por exemplo: no clima de angústia do século XVII, em que o autor do século XX pode encontrar algum espelhamento. Por outro lado Boroncini, fala da "poética do deslumbramento" (poetica della meraviglia) e da imaginação. Segundo a autora, esses seriam dois instrumentos de conhecimento do homem moderno. Seria este o paradigma do moderno iluminado pelo Barroco.

\footnotetext{
de "barroco" e "neobarroco" são operatórios, como o "neobarroso" na foz do Rio da Prata, de Néstor Perlongher; o "barroco" como "simbiose" ou "mestiçagem" contínuas que engendram "barroquismo", segundo Alejo Carpentier, para quem as pirâmides de Teotihuacán também são "barrocas". Um uso muito influente de "barroco" e do "presente de produção" poética e artística proposto por Haroldo de Campos. No caso, "neobarroco" significa a novidade contemporânea produzida por uma invenção artística que, apropriando-se sincronicamente de procedimentos técnicos e efeitos das artes do século XVII, usa-os como matéria de transformações poéticas. O nome "neobarroco" dos objetos estéticos é posto por meio de analogias estabelecidas entre seus efeitos e os efeitos das artes do passado classificadas como "barroco". Na apropriação poética dos restos, propõe-se, com Jauss, Iser, Paz, Sarduy e outros, a exemplo do que T.S. Eliot fez com a poesia de Donne e Marvell, ou García Lorca com a de Góngora, que o conhecimento da poesia de Mallarmé, por exemplo, permite ao poeta contemporâneo reconhecer o valor estético da poesia de Góngora, que é constituído retrospectivamente como precursor. Não é o asianismo de Góngora, no final do século XVI, que antecipa as divisões prismáticas da Idéia da poesia de Mallarmé, no XIX, mas a leitura de Mallarmé por um poeta do século XXI que permite constituir a poesia de Góngora como uma tradição do novo ou de determinado modo contemporâneo de compor poesia segundo um cânone poético "de invenção." (p. 16-17, nota n. $\left.{ }^{\circ} 10\right)$

312 UNGARETTI, Giuseppe. Invenzione della poesia moderna: Lezioni Brasiliane (1937-1942), a cura di MONTEFOSCHI, Paola. Napoli: Edizioni Scientifiche Italiane, 1984, p. 252-253, tradução nossa.

313 BARONCINI, Daniela. Ungaretti barocco. Roma: Carocci Editore, 2008.

314 BARONCINI, Daniela. Op. cit., p. 19.
} 
Outra possível reverberação do Barroco no pensmento de Ungaretti é a qualidade de chiaroscuro com a qual o poeta define o segredo da poesia. Este enigma é um caminho que percorre sua pesquisa sobre a língua, essa constatação do mistério inacessível da linguagem poética. $\mathrm{Na}$ introdução às suas traduções de Blake, Ungaretti escreve: “[...] o verdadeiro poeta anseia pela clareza: fica ansioso por revelar todo segredo: o próprio, o segredo de sua presença terrena procurando conhecer o segredo do caminhar da história e dos motivos que regem o universo, tentando tomar posse, enlouquecido, do segredo dos segredos". ${ }^{315}$ No entanto, a questão não se encerra aí, pois o poeta tem consciência de que a palavra é difícil e, por isso, segundo Ungaretti, desespera-se diante deste fato, torna a palavra ainda mais obscura, mais presa em seu significado. Quanto mais tenta descobri-la com lances de luz, mais a encobre, multiplicando-se assim o mistério. ${ }^{316}$

O desconhecido, tanto na poesia quanto na linguagem, é algo que atravessa sua obra, nela vai assumindo outros sinônimos: mistério, segredo, milagre. O Leopardi resgatado por Ungaretti é aquele que "sente que há um mistério", 317 e, quando escreve sobre Racine, afirma que "[...] a verdadeira poesia se apresenta para nós, antes de mais nada, em seu segredo. É o segredo que, em nossa alma, acompanha também os descobrimentos e a delimitação da mesma. Faz-se, aliás, naquele momento, o segredo mais profundo". 318 No prefácio à edição de traduções de Góngora a Mallarmé (1948), afirma: “[...] estou convencido de que buscar a verdade fora da letra, é um esforço inútil", ${ }^{319}$ como citamos anteriormente, e o valor da letra, em sua passagem de uma língua à outra, encerra também aquela ponta de segredo e mistério ungarettiano, algo que reverbera em seus versos, como já no início, em Il Porto Sepolto: "quel nulla / d’inesauribile segreto": "aquele nada / de inextinguível segredo".

Se recuarmos um pouco mais, podemos pensar também na presença de certo Barroco na poética de Ungaretti que se mostra através do fragmento, algo evidente na poesia de Il Porto Sepolto e L'Allegria, mas também em sua produção mais tardia. Walter Benjamin, em $A$ origem do drama barroco alemão, ${ }^{320}$ reflete:

As alegorias são no reino dos pensamentos o que são as ruínas no reino das coisas [...] não se trata tanto de uma reminiscência antiga, como de uma sensibilidade estilística contemporânea. O que jaz em ruínas, o fragmento significativo, o estilhaço: essa é a matéria mais nobre da criação barroca. Pois é comum a todas as obras literárias desse período

\footnotetext{
315 UNGARETTI, Giuseppe. Vita d'un uomo. Traduzioni poetiche. Milano: Mondadori, 2010, p. 613.

316 UNGARET'TI, Giuseppe. Vita d'un uomo. Traduzioni poetiche. Milano: Mondadori, 2010, p. 613.

317 UNGARETTI, Giuseppe. Vita d'un uomo. Saggi e Interventi. A cura di Mario Diacono e Luciano Rebay. Milano:

Mondadori, 1974, p. 483.

318 Ibid, p. 579.

319 UNGARETTI, Op. cit., 2010, p. 211, tradução nossa.

320 BENJAMIN, Walter. A origem do drama barroco alemão. Trad. Sergio Paulo Rouanet. São Paulo: Brasiliense, 1984.
} 
acumular incessantemente fragmentos, sem objetivo rigoroso, confundindo estereótipos com enriquecimento artístico, na incansável expectativa de um milagre. Os literatos barrocos devem ter considerado a obra de arte como um milagre, nesse sentido. ${ }^{321}$

Observando este trecho de Benjamin, podemos recordar como há algo em comum na interpretação que o poeta dá ao Barroco, mas também à poesia. Sem querer aqui moldar Benjamin para encaixá-lo às observações de Ungaretti, podemos no entento trazer à tona alguns elementos de contato entre os dois. Se antes observamos a dimensão do mistério e do milagre, presentes nos versos e nas definições do poeta, agora podemos nos deter um pouco na questão da decadência, da ruína, do fragmento. Nesse sentido, pode ser oportuno avançarmos um pouco além de L'Allegria e observarmos sua obra Sentimento del tempo, na qual a camada barroca da capital italiana fala ao poeta através de suas ruínas. Por exemplo:

Una città come Roma, negli anni durante i quali scrivevo il Sentimento, era città dove si aveva ancora il sentimento dell'eterno e nell'animo nemmeno oggi scompare davanti a certi ruderi. Quando si è in presenza del Colosseo, enorme tamburo con orbite senz'occhi, si ha il sentimento del vuoto. A Roma si ha il sentimento del vuoto. 322

Adentramos o magma do livro Sentimento del Tempo ao pensarmos em temas como o eterno e a caducidade, o efêmero, as ruínas e também o sentimento de vazio - hororr vacui — algo já presente na obra de autores barrocos. Segundo Carlo Ossola, Sentimento del Tempo é uma obra se compôs lentamente. Em 1923, há um primeiro grupo de poemas importantes do volume que permanece incluso na reedição de Il Porto Sepolto ("Sirene”, "Le Stagioni”, "Alla Noia", "Silenzio in Liguria", "Paesaggio", "O note"), ${ }^{323}$ o crítico observa que os "ciclos" do livro delineam-se tardiamente, entre 1925 e 1927. Afirma:

Soltanto Roma, da cui poi per smembramento nasceranno: D'agosto, Un lembo d'aria, Ogni grigio, presenta uno dei nuclei portanti del Sentimento: il mito di Roma, Roma barocca, città non dei trionfi ma delle rovine, di monumenti consunti da tempo, abbacinati dall'estate; Roma degli Inni cristiani, della colpa e della titanica redenzione di Michelangelo, Roma della Morte meditata. ${ }^{324}$

E Ungaretti continua a reiterar que só em Roma é possível sentir esse vazio, esse horror do vazio "infinitamente mais intenso [...] do que no deserto, mais do que em qualquer

\footnotetext{
321 Ibid., p. 200.

322 UNGARETTI, Giuseppe. Vita d'un uomo. Tutte le poesie. A cura di Leone Piccioni. Milano: Mondadori, (1969) 2001, p. 533.

323 OSSOLA, Carlo. Ungaretti, poeta. Veneza: Marsilio Editori, 2016. p. 38-42.

${ }^{324}$ Ibid.
} 
outra parte da terra". ${ }^{325}$ Há em Sentimento del Tempo a cristalização de observações que o poeta já vinha amadurecendo desde os anos no Brasil, em suas anotações sobre Leopardi, seu poeta tão admirado que é capaz de colher a palavra "como uma ferida de luz no escuro", 326 aquele que fala do "declínio musical das coisas" que, com a ilusão do infinito, sugere a vaidade de tudo. ${ }^{327} \mathrm{~A}$ chave de leitura que adotamos aqui é justamente aquela muitas vezes repetida por Ungaretti sobre a capacidade de contornar o escuro com alguma luz, com alguma harmonização — justo o que o poeta aponta no trabalho de Borromini, o eixo de onde parte para criar suas críticas a Picasso, numa carta escrita a Bruna que será analizada mais adiante nesse trabalho.

Mas o sentido do barroco capturado por Ungà nos versos de Bruna foge destas observações, foge do sentido que dá às traduções que faz da poesia de Góngora. Quando fala de barroco na poesia de Bruna, Ungaretti se refere às repetições que a jovem poeta faz, arzigogolature, diz — “exageros", "elucubrações”. Não é esse o barroco que Ungaretti observa na poesia de Bruna nem a lição que ele extrai de Góngora. Pensemos aqui nas observações de Ossola ${ }^{328}$ sobre as traduções do poeta: “tradurre Góngora induce Ungaretti a ritornare al significante e a restaurare la sitassi per serie fonitiche, [...] il trionfo barocco della parola è tutto racchiuso in mallarmeana disciplina fonética", ${ }^{329}$ ou seja, Ungà bebe do barroco para criar dentro de uma disciplina fonética mallarmeana, e é isto que diz quando se refere à necessidade de temer um pouco o barroco, como na Carta n. ${ }^{\circ} 19$ :

Amável amor, pupila dos meus olhos, é mais urgente do que tudo direcionar o pensamento aos teus dois últimos poemas. Tudo bem a simetria do branco e do preto que aqui é também a origem de um contraste. Será, porém, necessário estar atentos ao recorrer a meios expressívos semelhantes, para que não resulte como uma elucubração. Tua poesia lembra um pouco Góngora. É um grande mestre. Mas é preciso temer um pouco o barroco, ainda sendo tão presente, e magnificamente presente, no nosso Brasil. ${ }^{330}$

A revalorização de Góngora é um movimento que surge com os simbolistas franceses ${ }^{331}$ e é seguido pelo renovador da língua espanhola, o nicaraguense Rubén Darío. Para Ungà, além de seguir esse fluxo, há uma importante herança de Petrarca que, para chegar a

\footnotetext{
325 OSSOLA, Carlo. Ungaretti, poeta. Veneza: Marsilio Editori, 2016, p. 39.

326 "Immagini di Leopardi e nostre", apud. OSSOLA, p. 40.

327 Ibid.

328 OSSOLA, Carlo. Da Góngora a Mallarmè. In UNGARETTI, Giuseppe. Vita d'un uomo. Traduzioni poetiche. Op. cit., p. 1359.

329 Ibid. p. 370.

330 Carta n. ${ }^{\circ} 19$, datada de 23 de outubro de 1966.

331 “Após três séculos de calunia e desprezo da parte dos acadêmicos e professores, desprezo que se refletiu até no adjetivo popular 'gongórico', Góngora celebrou uma ressureição vitoriosa, o que tornou antiquado todos os velhos manuais de literatura espanhola e universal" (CARPEAUX, Otto Maria, apud CAMPOS, Haroldo de. O sequestro do barroco. São Paulo: Iluminuras, 2011, p. 59).
} 
Mallarmé, passa por Góngora. Dessa forma, adverte Bruna sobre aquilo que poderia ser uma conotação de estilo rebuscado e oco, ou seja, o contrário da lição que tenta extrair ao traduzir Góngora ou Shakespeare. Ao falar da poesia de Bruna, Ungaretti coloca em prática também os seus princípios em matéria de manufatura de versos, tocando também questões como influência e filiação literária. Sobre Góngora, observa Antonio Buxó: “[...] una poesia oscura, misteriosa no por vaguedad sino por excesso de concentración en el intento de restituir a la palabra sus olvidadas significaciones, de aspirar a expresar el mundo en su pureza essencial". ${ }^{332}$ É nessa característica que se faz o percurso de Ungaretti, que traduz para melhor ler o poeta barroco. Segundo Ossola, é também o percurso que ele encontra para ter acesso aos segredos da poesia de Petraraca, pois a tradução de Ungaretti coincide com a época em que são publicados os ensaios críticos de De Robertis e Contini. ${ }^{333}$ A história literária se move entre rejeições e novas recepções, e essa é a trilha que conduz Ungaretti. Pensamos aqui na análise de Haroldo de Campos quando revê Gregório de Matos para fazê-lo voltar a Góngora:

O auge do processo de rejeiçao ocorreu, segundo Diego, entre "18501900, época da mais triste indigência, triunfo da gongorofobia oficial", até que o resgate (o novo desdobramento agora favorável, da história receptiva da poesia gongorina) começa apontar com o grande renovador das letras hispano-americanas Rubén Darío, precedido pelos simbolistas franceses (que encontravam analogias entre Góngora e Mallarmé) ${ }^{334}$

Para entendermos melhor a apropriação do barroco por parte de Ungaretti, para pensar o seu presente, é oportuno voltar ao seu ensaio "Góngora al lume d’oggi”, publicado em 1951. ${ }^{335}$ Aqui, Ungaretti admite que, uma vez, falando sobre o Don Quixote, se deu conta do elemento fundamental do Barroco que o capturava. Diante de um mundo desprovido de sentido, irreal, cheio de enganos, o espaço para pensar a verdade passa a existir com a possibilidade da imaginação, e diz: "ammetto oggi ancora che sia questa riconseguita libertà d'immaginazione, uno degli apsetti seducenti del Barocco [...]"; ;36 imaginação essa que abre espaço para que até mesmo a angústia aponte para um caminho de lucidez. E continua: “[...] nell'argutezza, il Góngora aveva compreso un impeto emotivo di grado tale da farla apparire anche a poeti europei del secondo quarto del Novecento, mezzo lirico

\footnotetext{
332 BUXÓ, JP. Ungaretti traductor de Góngora, Maracaibo: Universidade de Zulia, 1968, p. 32.

333 UNGARETTI, Giuseppe. Vita d'un uomo. Traduzioni poetiche. Op. cit., p. 1362.

334 A antologia de traduções de Ungaretti é elaborada entre 1932 e 1948. Refêrencia da citação de CAMPOS, Haroldo

de. O sequestro do barroco. São Paulo: Iluminuras, 2011, p. 58.

335 UNGARET'TI, Giuseppe. Vita d'un uomo. Saggi e Interventi. Op. cit., p. 528-550.

336 Ibid., p. 529.
} 
nuovissimo volendosi rivestire liricamente un'angoscia che, quale la loro stava diventando, fosse, quantunque furiosa, lucidíssima". ${ }^{337} \mathrm{O}$ que interessa para Ungaretti é essa ponte entre um mundo em que os sentidos se mostram sempre menos confiáveis e a ação do poeta que usa a palavra como possibilidade de resgate, apontando o prodígio do efêmero. Essa é uma das lições fundamentais do Barroco para o poeta:

[...] concettualmente, il mondo dei sensi si mostri, nei suoi effetti, sempre più falso, sarà quella più che mai il'ora per un poeta di affannarsi a dimostrare come un colore fugace, come il momento deludente d'un oggetto perituro possa tutto invadere in um vocabolo, ristabilire con risoluta violrenza nelle funzioni d'un semplice vocabulo, il prodigio dell'effimero. 338

Ocupado por este sentido de resgate do Barroco é que Ungaretti olha para a poesia de Bruna. O poeta tenta traçar observações para promover um aprimoramento, como se houvesse, no fundo do seu pensamento, da lição de Paulhan que aparece no ensaio "Il sarto cinese", traduzido por Ungaretti em 1945 para o caderno "Poesia": "Per ogni inventore di linguaggio, selvaggio o civilissimo ch'egli sia, le immagini non sono mai inseguite per gusto immaginifico, ma solo per nominare una cosa che non si sapeva come altrimenti indicare". ${ }^{339}$ Seguem-se as imagens para tentar nomear algo que era antes desconhecido, pois, segundo Paulhan, esse é o destino do poeta, "inventore per antonomasia di linguaggio, che anche gli atti più semplici siano a lui difficili” — até os atos mais simples sejam, para ele, difíceis.

Surge mais uma vez um reconhecimento do Barroco num poema de Bruna, desta vez na Carta n. $.^{\circ} 26:$

Tem um efeito surpreendente, pensando novamente, aquele teu poema do sangue e da rosa. Para quem conhece a obra, um efeito análogo produz a identificação de Jesus que sobe o Calvário, misticamente sentido por Santa Teresa D'Ávila ou por São João da Cruz, e expresso com sublime perfeição nos cantos de Um e nos da Outra. Talvez, pensando melhor, assemelha-se mais teu canto barroco à Via Crucis manuelina, mais ao manuelino da Bahia que ao de Portugal. Não é mal, aliás, é sinal de autenticidade. Talvez deveria dar-se ao teu canto, já ótimo, maior laconismo, mas são cantos, eu sei, que exigem um mínimo de eloquência. ${ }^{340}$

Será que Ungà entendia por manuelino da Bahia Gregório de Matos? Pouca semelhança teria com a tentativa nos versos de Bruna, entre o olhar generoso do poeta, para dialogar com a jovem aspirante poeta, havendo aqui uma provocação e convite para outras leituras e referências. Não um Barroco só, há uma multiplicidade de referências quando se fala

\footnotetext{
${ }^{337}$ Ibid., p. 530.

338 UNGARETTI, Giuseppe. Vita d'un uomo. Saggi e Interventi. Milano: Mondadori, (1974) 2001, p. 530.

339 Ibid., p. 532.

340 Carta n. ${ }^{\circ} 26$.
} 
neste período, em seus autores, em suas representações em diversas geografias. O Barroco será evocado outras vezes por Ungaretti nessas cartas. Num pequeno desvio, por exemplo, quando comenta a exposição de Picasso: “[...] claro, o barroco parte do monstruoso, do cataclisma, mas termina também, ainda que com desespero como em Borromini, com encontrar uma reconstrução harmoniosa da ruína". ${ }^{341}$

O poeta de Sentimento del Tempo carrega sempre em si sua Roma barroca, quando, por exemplo, imagina em quais lugares levará os irmãos de Bruna - Marco e Bruno — para passear, quando se encontrarem. Borromini surge outra vez:

Quando virão para Roma, Bruno e Marco, gostaria de lhes mostrar várias coisas. Aqui nasceu o Barroco. Roma é a cidade Barroca mais extraordinária do mundo. Trabalharam aqui Bernini e Borromini. Do Borromini gostaria de lhes mostrar algumas obras. Era o arquiteto mais fantástico que do mundo, talvez o maior em todos os sentidos. Era ticinês. Morreu jovem, suicida. Os seus monumentos são loucuras de equílibrio. As diversas partes mantêm-se em pé, com uma harmonia insuperável, como os objetos que carregam um sobre o outro, um monte de objetos, um ilusionista de circo. ${ }^{342}$

A resignificação de sua relação com o Brasil, através do amor e da convivência com Bruna, mas também com seus irmãos que na época moravam na Itália, onde estudavam, ajudanos a pensar o movimento de um novo redescobrimento do Barroco:

Desejo, em suma, confessar que devo ao Brasil se cheguei a entender o Barroco que inflige tanto tormento, há tantos anos, à minha inspiração e à minha técnica expressiva. Compreendi, claramente, no Brasil o valor de choque que havia no Barroco e por que razão o encontro entre inocência e memória e entre natureza e razão devesse sempre manifestarse violento." 343

O barroco para Ungaretti é sobretudo a sua manifestação arquitetônica, de certa forma um espelhamento, um duplo, a construção na arte e nos edifícios e a consturção da natureza brasileira. É mais importante falar de Borromini do que de Bernini: ao visitar a Galleria Borghese com Marco e Bruno em 1967, Ungaretti não faz nenhuma observação sobre a tão conhecida estátua de Apollo e Dafne. O poeta observa o gesto barroco como algo que sai do pensamento e se encaminha para a natureza, quase como se no contrafluxo do que seria esperado, e é nessa surpresa que se encontra o terreno mais fértil para a invenção da linguagem. "Sarà poco razionale che si parta dalle idee per approdare alla natura, ed è, è

\footnotetext{
341 Carta n. $^{\circ} 41$, datada de 27 de novembro de 1966. 342 Carta n. ${ }^{\circ} 184$, datada de 8 agosto de 1967.

343 UNGARETTI, Giuseppe. Invenção da poesia moderna: lições de literatura no Brasil, 1937-1942. Texto estabelecido por Paola Montefoschi. Tradução de Antônio Lázaro de Almeida Prado. São Paulo: Ática, 1996, p. 266.
} 
vero, un po' come incominciare dal tetto a fabbricare una casa ma da quando è sucesso il Barocco, l'arte sembra non possa più rinnovarsi se non per prodezze, riconosciamolo, pazze". ${ }^{344}$ Para Ungaretti, essa radicalidade se inaugura com o Barroco, por isso sua preocupação com esse resgate. No entanto, a situação da invenção da linguaguem carrega em si sempre esse furor. Enfim, o poeta se preocupa se todos os comentários tecidos sobre o trabalho poético da jovem poderiam ter inibido sua escrita, e assim, em fevereiro de 1967, ele escreve:

E poesias? Não as escreves mais? É verdade que cada frase das Tuas cartas é um poema, e seria possível extrair um dos livros mais lindos destes anos. Um livor lúcido, exaltante, que infunde luz, que conforta, que surpreende pela novidade das imagens, que não procura, como diza uma vez Picasso sobre si mesmo, a poesia, mas a encontra. ${ }^{345}$

Para além do dialogo poético entre os dois, para além do livro de líricas trocadas, há uma instância de diálogo e de troca entre aspectos presentes na mesma pessoa. Ungaretti escreve para Bruna, mas escreve possuído pelo mesmo gesto poético descrito por Paulhan em "Il sarto cinese": escreve buscando nomear o que desconhece, não só do mundo, mas de si. Dessa forma também ressurge o Barroco nas cartas dedicadas a Bruna.

\subsection{ARTES PLÁSTICAS}

O vínculo de Ungaretti com as artes plásticas è composto por um duplo movimento: por um lado uma reflexão extensa sobre artistas que o impactaram, por outro, uma teia de suas relações pessoais, sua proximidade com artistas so seu tempo, muitos com os quais colaborou em suas publicações. Nas cartas a Bruna há uma recorrência de citações de nomes de artistas plásticos, obras de arte, exposições e colaborações e anedotas de suas vivências. Bruna possui alguns quadros de Cagli, em sua coleção - presentes recebidos durante sua viagem à Europa em 1968 junto ao poeta.

Muitos dos textos escritos por Ungaretti sobre as artes plásticas estão contidos no volume Saggi e Interventi, de sua obra completa, na coleção Meridiano da editora Mondadori. Entre eles podemos destacar suas reflexões sobre Vermeer. Os textos faltantes foram reúnidos, recentemente, no volume Ungà. Giuseppe Ungaretti e l'arte del XX secolo curado por Angela Madesani. ${ }^{346}$ Há, porém, nas cartas a Bruna, uma riqueza de referências. Estes detalhes são difusos e entermeados entre outras discussões, presentes em muitas cartas. $\mathrm{O}$

\footnotetext{
344 UNGARETTI, Giuseppe. Vita d'un uomo. Saggi e Interventi. Op. cit., p. 533.

${ }^{345}$ Carta n. $^{\circ} 113$.

346 MADESANI, Angela. Ungà. Giuseppe Ungaretti e l'arte del XX secolo. Busto Arsizio: Nomos Edizioni, 2014.
} 
que propomos aqui é um eixo de leiutra destas missivas que passe por este crivo. Quais os artistas citados e em que contexto? Talvez uma das missivas mais ricas seja a do dia 27 de novembro de 1966, na qual o poeta não só fala de arte mas retoma com profundidade o tema da luz. Esta palavra-conceito é frequentemente usada como um vocativo para nomear sua amada, Mia Luce, è também um elemento central e interpretativo de sua pesquisa pessoal, algo que permeia seus versos, suas indagações.

Há como pano de fundo às observações que tece sobre os artistas, suas próprias obsessões, seus temas. A carta 41, do dia 27 de novembro de 1966, é uma abertura, uma pequena fissura, através da qual podemos vislumbrar as vértebras que sustentam a coluna da vida de um homem. Seria o amor senil, tão frequentemente confessado e etiquetado como demente, a oportunidade para pensar, rever e refletir, talvez talvez até organizar o compedio de toda uma vida, de toda sua trajetória poética? Nos mesmos anos em que escrevia para Bruna, Ungaretti organizava sua obra completa.

\subsubsection{O tempo e a construção da escuta}

Em cada carta desse volume, pode-se percorrer a vida e a obra do poeta, um fragmento que remete ao todo. Por um lado, há o esquecimento dos anos passados, por outro a tentativa de ressignificar a existência tendo como data de renascimento, de novo começo, o encontro amoroso com Bruna. Daremos maior atenção à Carta n. ${ }^{\circ} 41$, pois nela o poeta não só discorre sobre a arte e sobre os artistas amigos, interlocutores, mas coloca-os em relação com a sua poética. É neste fim de 1966 que o poeta escreve a Bruna para falar de Picasso, de Vermeer, de Cézanne, de Braque, de Fautrier. Começa sua escrita criando algo fundamental que sempre surge nessa relação epistolar: ele cria uma escuta. Descreve a natureza do relacionamento entre eles e demarca a diferença generacional que os divide os seus anos, que já podem se contar em séculos, dos de Bruna, que se contam em lustros. No entanto, a idade aqui não é apenas a demarcação de uma diferença, mas também uma oportunidade de falar do tempo: parte-se deste ponto para dar uma nova significação ao tempo. Este ouvido leggiadrissimo — gracioso ou rápido — do qual fala o poeta é, no fundo, o olhar de Bruna sobre as palavras escritas. Um olhar que sabe acolher o que Ungaretti lhe escreve. É este acolhimento e essa correspondência que o animam: "[...] sinto-me tão ansioso por te ver novamente" — ele diz — “[...] não vivo se não desta única 
esperança". ${ }^{347}$ É a escuta amorosa e exclusiva, a leitura de suas palavras escritas, o que parece acomodar a contradição da idade que os separa, a contradição do tempo. Ainda que o poeta possa calcular "o tempo em séculos", ele também diz: "os anos, os esqueci todos". Podemos observar o autor de Sentimento del Tempo novamente nessas missivas. Os anos dessa correspondência são também os anos em que o poeta prepara o volume de sua obra completa, Vita d'un nomo. Conforme Ungaretti vai revisitando a sua obra e a sua vida, parecem coexistir o poema das trincheiras e o da inovação, o poeta dellinnervaz̧ione del linguaggio, o tradutor, o homem com o olhar e os ouvidos atentos à sensibilidade barroca, o observador dos detalhes do mundo que o circunda, o crítico das artes plásticas. Percebemos, logo no primeiro parágrafo da Carta n. ${ }^{\circ} 41$, uma articulação entre presente, passado e eternidade, o retorno do tema do tempo:

Talvez por serem muitos, mas antes de ti o numero deles era quase o mesmo, e eu podia percorrer sua longa duração. Hoje, do meu tempo, não me lembro de mais nada que não seja o que corre desde que te encontrei. Breve tempo, mas o mais longo que se possa conhecer. ${ }^{348}$

Invocar a presença de Bruna e percorrer novamente sua trajetória é como um "grido nel sileñio", na prosa assim como nas epístolas ou nos versos do poema "Tutto ho perduto": "La vita non mi è più,/ Arrestata in fondo alla gola, / Che una roccia di gridi". Ungaretti passa da construção de uma escuta — em alguns aspectos até imaginária — para a ressignificação do tempo: um breve tempo, o mais longo que já conheceu. As primeiras linhas são como um prelúdio, para então dar início ao relato do cotidiano, das decisões tomadas, ou seja, de sua saída da comissão da Unesco. A carta é escrita nos dias da abertura da grande exposição dedicada a Picasso em Paris. No mesmo hotel onde se hospedara Ungaretti, também estavam outras personagens das artes e da literatura. O poeta cita, entre eles, o escultor Marino Marini e a diretora do Museu de Arte Moderna de Roma, Palma Bucarelli, além do escritor e jornalista Paolo Monelli, então companheiro da Bucarelli.

Ungaretti cita a grande exposição que celebra os oitenta e cino anos de Picasso, uma homenagem importante e uma retrospectiva que ocupou diversos locais da capital francesa, mas especialmente o Grand Palais. A exposição contou com oitocentos itens, incluindo quadros, esculturas e cerâmicas, entre eles a Demoiselle d'Avignon citado pelo poeta na sua carta. Havia na exposição muitas esculutras de Picasso: não por acaso, podemos ler nesta carta um longo comentário de Ungaretti sobre as anfôras do artista. Vamos dedicar

\footnotetext{
${ }^{347}$ Nesse trecho, serão citadas partes da mesma missiva — a Carta n. ${ }^{\circ} 41$ — cujas transcrição e tradução encontram-se no final deste capítulo.

348 Carta n. $^{\circ} 41$.
} 
nosso olhar ao estilo e à natureza das observações ungarettianas a respeito das artes plásticas, pois, nesse sentido, a Carta n. ${ }^{\circ} 41$ é exemplar de um movimento recorrente em sua escrita: tudo o que o atuor descreve está em relação consigo e com a sua construção de sua obra, com os seus temas. Em primeiro lugar, Ungaretti é crítico de si mesmo, do seu trabalho, especialmente no sentido de re-percorrer a sua trajetória — e, nesse sentido, há algo de um registro diarístico nessas cartas, pois, ao passo que organiza a sua obra, ele revê a sua vida e segue narrando à amada essas questões somadas às vicissitudes do cotidiano. Fala de Picasso, mas traz à tona suas descrições e indagações sobre a luz nos quadros de Vermeer e Cézanne, relacionando essas questões aos temas presentes em sua obra.

\subsubsection{O caráter europeu da obra e das relações de Ungaretti}

O caráter europeu da obra e da vida de Ungaretti se desdobra em dois frontes: por um lado, há a tessitura artística e literária presente em sua obra, por outro, há a trama de relações e vínculos com personagens, autores e tradutores europeus. O vínculo é, portanto, mais profundo e se manifesta não somente nas refrações artísticas, mas também nas articulações e colaborações: textos para catálogos, traduções e exposições. Também na Carta n. ${ }^{\circ} 21$, é possível observar essa natureza dúplice. O poeta, após ter apresentado a Bruna, em sua narrativa, a diretora do museu romano, Palma Bucarelli, relata ter escrito o prefácio do catálogo de uma exposição de Fautrier curada por ela — e na mesma página já apresenta o nome de Braque, contando que Bucarelli escreveu sobre este artista. O que o poeta começa a narrar para Bruna é a articulação para outra grande exposição de Fautrier em Roma, no próprio Museu de Arte Moderna. Caminham juntas as reverberações artísticas e as redes de relacionamento que mantêm o poeta não apenas muito ligado a toda a produção artística europeia, mas também numa posição de privilégio, enquanto poeta e intelectual italiano.

Partindo agora de algumas cartas, e tendo como ponto alto a já citada Carta n. ${ }^{\circ} 41$, vamos tecer algumas observações sobre os pintores citados, relacionando-os à sua obra.

\subsubsection{Picasso}

Talvez as cerâmicas, com certas figuras em que o corpo humano não está ofendido, são as obras que mais me persuadiram. Não se pode duvidar, é um artista de uma cultura visual sem comparação, viu todos, os negros e os mexicanos, os românticos catalães, e Rafael, e os Gregos, e Pompéia e Erculano, e o barroco, especialmente o barroco, quando feita forjada a fogo, ${ }^{349}$ a sua pintura é persuasiva. ${ }^{350}$

\footnotetext{
${ }^{349}$ Sobre a ambíguidade dessa frase, ler a nota na carta traduzida na íntegra ao final deste capítulo.

${ }^{350}$ Carta n. ${ }^{\circ} 41$.
} 
Não podemos nunca nos esquecermos da natureza da escrita epistolar, em alguns momentos improvisada, editada na hora, às vezes sem releitura. Há momentos em que a compreensão do texto é difícil em italiano, e difícil também a arte de transcrever as palavras e fixar esse texto. Já nesta própria citação ocorre uma confusão com a palavra lesa em italiano, que não parece ter significado algum. Embora transcrita da forma em que foi escrita, acrescentamos à transcrição uma nota interpretativa, no sentido de que talvez pudesse se tratar do verbo rendere conjugado como resa, ou seja: "quando resa dal fuoco". Optamos, neste caso, pelo verbo "forjar": a pintura de Picasso forjada a fogo, como nas cerâmicas, seria então, para Ungaretti, mais persuasiva. A palavra permanece aberta à interpretação póstuma. Talvez não se tratasse de "resa dal fuoco", mas sim de "leva dal fuoco", ou seja, "tira do fogo". Adotamos "resa dal fuoco", que, além de "forjada a fogo", poderia, talvez de forma ainda mais exata, significar: "tornada", "transformada", assim, "pelo fogo".

Muitas das cartas que compõem este volume, especialmente as que narram as viagens e refletem sobre a arte ou a escrita poética, podem ser lidas com tanta desenvoltura que, por alguns momentos, é possível esquecer o fato de serem descrições contidas em cartas e não uma prosa avulsa, fruto de algum ensaio. Essa característica nos faz pensar que talvez, em alguma medida, fossem escritas com o desejo de encontrarem também os olhos de um público leitor mais amplo. Há, em algum momento, declarações mais explícitas sobre o desejo da publicação de algumas cartas junto aos poemas trocados, no volume Dialogo. No fim das contas, só passam pelo crivo editorial os poemas, porém, cabe mencionar aqui o diz Ungaretti em fevereiro de 1967:

Sabes o quanto se pagaria por nossa correspondência, se fosse colocada à venda? Uma biblioteca americana pagaria muitos bilhões. ${ }^{351}$ Mas não está à venda, é o nosso ardente segredo, e para nós vale mais do que todos os bilhões que existem na terra, e continuarão eles, os malditos bilhões, a fazer um massacre, da pobre terra. São as cartas em que aprendemos a dizer "TE AMO". Precisei de oitenta anos. Mas precisava para que te aprendesse ensinasse a dizê-lo enquanto és, como dizes tu, ainda uma criança. Fariam teses, estes idiotas. Sabe-se lá quais interpretações escandalosas inventariam. Malditas também as Bibliotecas e as Universidades. TE AMO. 352

\footnotetext{
351 Em junho de 2018, foram vendidas à Biblioteca Nazionale di Roma 170 cartas, um total de 630 papéis de Ungaretti, negociação feita pelo genro do poeta, Mario Lafragòla, no valor de 125 mil euros. A notícia circulou em diversos jornais italianos. (https://www.corriere.it/cultura/18_giugno_09/giuseppe-ungaretti-poeta-biblioteca-nazionale-roma-montale-pascoli-gozzano-zanzotto-lettere-manoscritti-b7b93cec-6c00-11e8-8d9c-84247469dc85.shtml, consultado em junho de 2018. As cartas escritas por Ungaretti a Bruna estão depositadas, quase todas, no fundo da Fondazione Mondadori, e continuam como propriedade da advogada e seus herdeiros, mas podem agora ser consultadas.

352 Carta n. ${ }^{\circ}$ 126, datada de 27 de fevereiro de 1967.
} 
Embora mantenha o tom jocoso, o poeta tem consciência do valor comercial das cartas. Ironiza o trabalho dos pesquisadores - sobretudo os que se ocupam em ler e estudar cartas - das universidades e das bibliotecas, ainda que tenha sido ele próprio professor universitário tanto no Brasil quanto na Itália. Relembramos aqui o comentário de Sanavio a respeito dessas missívas que transcrevemos e anotamos: "sem comentários sobre o voyeurismo da Mondadori". ${ }^{353}$

Mas voltemos a Picasso. Ungaretti descreve a imagem de uma mulher, soltando seus cabelos, retratada numa ânfora: "Há uma ânfora, com uma mulher que solta o cabelo, laranja sobre fundo branco, que não se tem vontade de parar de olhar"”. ${ }^{354}$ Em nossas pesquisas, vislumbramos que a obra se tratasse, talvez, de um vaso amplo, com a altura de 66 cm, cujo título é Gran vase aux femmes voilées, de 1950, no qual parece revisitar, mais explicitamente, temas clássicos, emulando ânforas gregas, fugindo de outros tipos de cerâmicas em que é mais presente aquilo que Ungaretti denomina como o "negador do homem" ou "furioso amante do monstruoso".
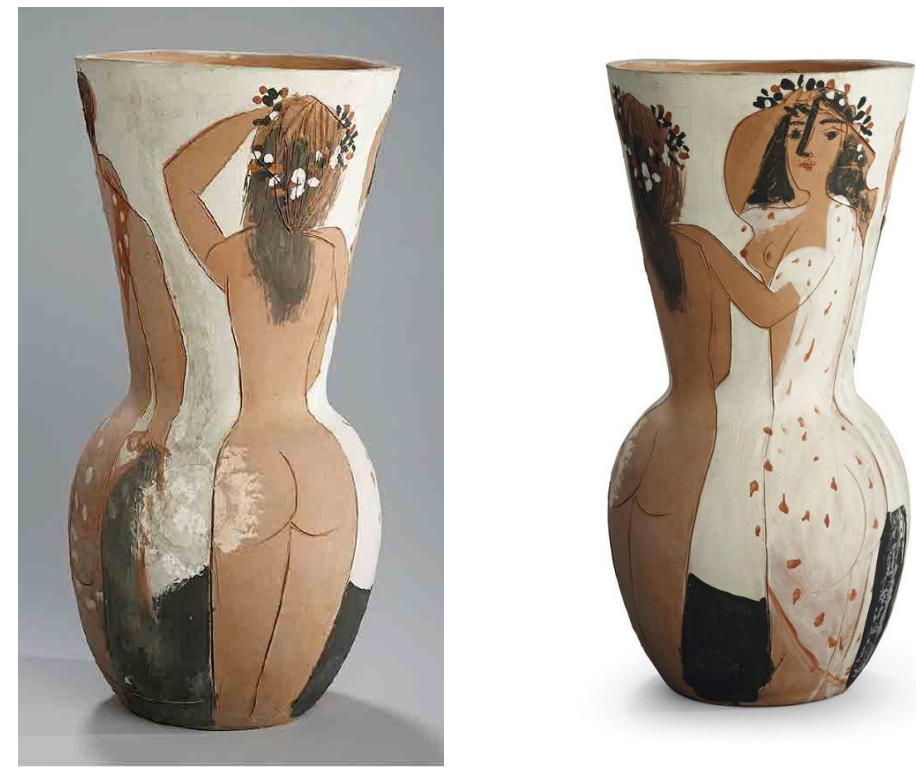

É o desenhista mais extraordinário, mais inexáurivel de recursos que já existiu. Mas que niilista, que negador do homem, que furioso amante do monstruoso, do desastre, pelo menos em tantas das suas obras. Desarticula os corpos, até o corpo da sua filha, decompõe-os, esquarteja-os, destroça-os, pisoteia-os, ofende-os, dá a eles uma desmedida obsessiva, com partes, os narizes das mulheres normalmente, de um erotismo do terror. Claro, o barroco partia do monstruoso, do cataclisma, mas

353 SANAVIO, Piero. Una corrispondenza: Dialogo Ungaretti- Bianco. Revista Malacoda (https://malacoda4.webnode.it/una-corrispondenza-dialogo-ungaretti-bianco, consultado em 14 de abril de 2019).

${ }^{354}$ Carta n. ${ }^{\circ} 41$. 
terminava mesmo com desespero como em Borromini, por encontrar uma reconstrução harmoniosa em sua ruína. Aqui, muitas vezes, não há mais do que a voluptuosidade de arruinar, a raiva pelo homem, de degradar. 355

A preocupação ungarettiana em "encontrar uma reconstrução harmoniosa em sua ruína" emerge com bastante força nessas linhas em que fala sobre Picasso. O que parece interessar realmente ao poeta é algo que ecoe em seus temas, em suas preocupações ou até mesmo no artista Picasso de outra época. Ungaretti procura convergir sua própria vida nas observações que tece. O poeta deseja, no fundo, voltar a falar daquele Picasso que não é ainda o "amante do monstruoso" e, talvez por esse motivo, Ungaretti coloque sua atenção nos desenhos que retratam personagens, amigos ou pessoas com as quais conviveu nos anos em que viveu em Paris, antes e logo após a Primeira Grande Guerra. Há, sobretudo na arte, um forte recorte europeu no pensamento de Ungaretti enquanto escreve a Bruna. Quando se distancia desses parâmetros, é porque está trazendo para a conversa o Brasil, os artistas e escritores brasileiros, o Barroco, Aleijadinho, as pessoas que fizeram parte de sua vida em São Paulo. Aqui, Ungaretti retorna aos anos em que viveu em Paris, onde conheceu Picasso. Por que o poeta retorna ao pintor nos anos da sua juventude? O que lhe interessa é o aspecto da obra de arte de outro que pode, em alguma medida, dialogar com a sua:

As obras que mais me tocaram - as encontrarás reproduzidas no catálogo — são alguns desenhos que retratam personalidades com quem manteve uma amizade, e são obras dos anos do imediato primeiro pós guerra. Vejo o retrato de Renoir, com aqueles punhos fechados pela artrite nos quais se fazia atar os pincéis, para pintar aqueles nus das serviçais adolescentes, que estavam, quando †os os vi, aqui em Paris, logo após a guerra, em 1920, na Bernheim Jeune, ainda de uma cor tomate atroz. Olha os olhos de Renoir, aquele velho Renoir que pintava com luxúria insuportável as garotinhas peitudas, os olhos vazios de Renoir, já vazios, com a morte no fonte fundo, a "volupté et la morte". E o ombro que se inclina de um lado. É a mais verdadeira obra de Picasso. ${ }^{356}$

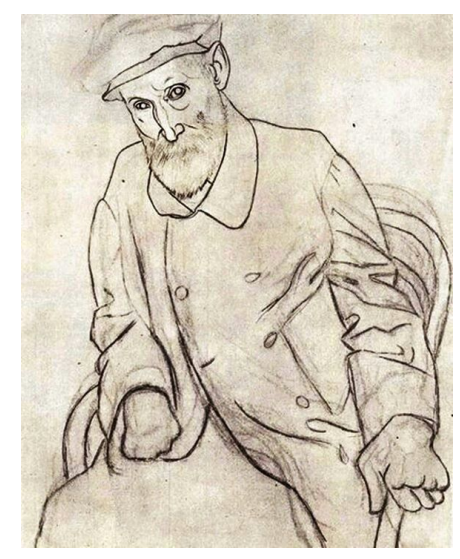

355 Carta n. ${ }^{\circ} 41$

${ }^{356}$ Carta n. $^{\circ} 41$. 
Claro, é a verdadeira obra de Picasso sob a luz analítica do cânone ungarettiano, sobretudo do poeta que em 1966 estava empenhado em organizar a sua obra completa, revendo, assim, toda sua vida, sua juventude, repensando suas referências e sua trajetória para compor Vita d'un nomo. Colocar o enfoque em seu pensamento analítico significa implicar no objeto suas vicissitudes pessoais, suas inquietudes. Cada pesquisa, cada crítica, cada pensamento do autor está atravessado pela dimensão biográfica:

Fui, quando jovem, companheiro de Picasso, e com tantos outros, com os quais fundou-se uma arte da qual Picasso marca a via mais audaz e mordaz da distruição e da negação. Exceto algumas vezes. Falo do Picasso depois de Demoiselle d'Avignon, que se direciona ao Cubismo, ou seja, do Picasso pós-1908, se não erro. Em 1920 Picasso, por um período não longo, após a viagem à Itália com os balés de Dia-ghilef, 357 durante a primeira guerra, tentou reencontrar a harmonia. Brevíssimo intervalo. Bem ou mal, mesmo não se omitindo de exprimir a tragédia humana da criação, que nos dias de hoje se faz assim tão às claras, aquele que assina esta carta, humildemente, desde '19 não parou mais de correr atrás da harmonia. ${ }^{358}$

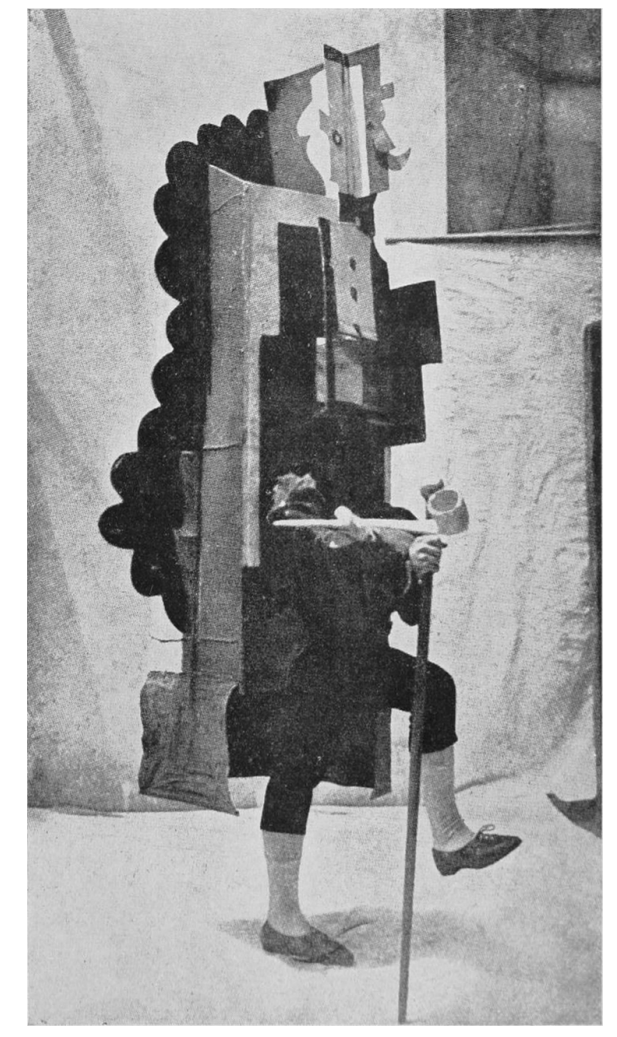

A marca da diferença surgem quando o poeta afirma ter se distanciado dessa forma de representação, ao dizer: “[...] bem ou mal, Bem ou mal, mesmo não omitindo de exprimir

\footnotetext{
357 Trata-se aqui de Sergej Palvolich Diaghilev (1872-1929), coreógrafo russo. Trabalhou muitas vezes com músicos e pintores de vanguarda. Picasso colaborou com ele para o espetáculo El sombrero de tres picos de Manuel de Falla, transformado em ballet em 1919.

358 Carta n. ${ }^{\circ} 41$.
} 
a tragédia humana da criação [...] aquele que assina esta carta, humildemente, desde '19 não parou mais de correr atrás da harmonia". Na introdução ao volume dos seus ensaios, Mario Diacono, que não só foi assistente de Ungaretti naquela época, mas também muitas vezes receptor das cartas de Bruna, retoma uma fala do poeta em que ele aproxima suas questões às de Picasso, num texto de 1929, e o faz explicando seu distanciamento de Mallarmé, ao dizer:

[...] i problemi di Mallarmé erano quelli di Monet, Renoir, Wagner, ed i miei problemi, della mia poesia che va dal 1919 al 1927, possono essere i problemi d'un Picasso o d'uno Stravinski. Tentativi di barocco esacerbato; problemi di trasposizione della realtà in un dominio di sogno; problemi di paesismo posti in relazione, $\mathrm{o}$ in contrasto, $\mathrm{o}$ in identità con stati e mutamenti psicologii, con divinazioni metafisiche. ${ }^{359}$

Via-se enfrentando os mesmos problemas que Picasso ou Stravinski, correspondendo às mesmas questões, ou seja, a transposição da realidade no domínio do sonho e a influência do barroco. O distanciamento entre as interpretações de Picasso e Ungaretti frente a questões semelhantes que os atravessam pode ser visto, segundo Diacono, na passagem do primitivismo ao Barroco. No caso do nosso poeta, seria o movimento que separa o livro Allegria de Sentimento del Tempo. Diacono afirma: "È a questo punto che Ungaretti comincia a risalire dal primitivismo dell'Allegira verso il barocco. In piena stesura di Sentimento del Tempo dirà: 'Intonro al '910, fece la sua comparsa nell'opera d'arte europea, il naso a spenitoio, e gli tennero subito bordone le parole in libertà"." ${ }^{360}$ Segundo o assistente e amigo de Ungaretti, a recusa do autor em relação ao futurismo literário, as palavras em liberdade, se soma à obra Les Demoiselles d'Avignon, que é de 1907, e ao Manifeto tecnico de Marinetti, de 1912. Não seria uma recusa completa ao primitivismo, já que, segundo Diacono, as forças presentes tanto na forma como no conteúdo da poética de Sentimento del Tempo são estas: há uma tensão perpétua entre o gesto primitivo e a consciência barroca. Há na interpretação de Ungaretti do Barroco, a não exclusão de certos aspectos de chiaroscuro.

A harmonia para Ungaretti não exclui a desarmonia nem os aspectos mais cruéis da existência humana, assim como a sua busca pela luz não exclui a escuridão — observação que ele faz quando escreve seu ensaio sobre Vermeer. A harmonia, no entendimento do poeta, pode percorrer um caminho com trechos desarmônicos, percorrer os abismos da incerteza, bem como o segredo inexaurível da poesia. O jogo de luz e sombra é uma forma de avançar no conhecimento do mundo, no conhecimento da arte poética, algo que amplia

359 UNGARETTI, Giuseppe. Vita d'un uomo. Saggi e Interventi. Milano: Mondadori, (1974) 2001, p. XXXI.

360 DIACONO, Mario. In Introduzione, Vita d'un Uomo. Saggi e Interventi. Op. cit., p. XXXIV. 
a capacidade de sentir e pensar. O mistério, como a sombra, é também o seu ponto de apoio. Como ele diz em Ragioni d'una poesia, "e il mistero è il soffio che circola in noi e ci anima". 361

\subsubsection{Vermeer e Cézanne}

Vermeer e Cézanne surgem também em outras cartas de Ungaretti dedicadas a Bruna. Porém, é notável como na Carta n. ${ }^{\circ} 41$ estejam preentes tantas reflexões sobre diversos artistas plásticos importantes para o poeta. Assim, há nestas páginas um salto de Picasso para o almoço com Paulhan. Da mesma forma que se move o pensamento do poeta quando reflete sobre os quadros de Vermeer, o olhar se desloca para a mobília na casa do amigo. A descrição de Ungaretti é cuidadosa, fala de um pequeno móvel em nogueira, sente-se atraído por esse objeto, sente-se fascinado. Nos mesmos dias em que está em Paris, visita a exposição de Picasso e então outra de Vermeer. São os mesmos anos em que escreve a pequena monografia para a coleção de arte "Classici dell'arte" da editora Rizzoli. Vermeer e Cézanne, com todas as suas grandes diferenças, permanecem como dois paradigmas constantes no pensamento do poeta, pois ambos trabalham com a luz como algo central. Na carta a Bruna, Ungaretti escreve:

Houve outra exposição que visitei durante esta semana. A exposição Vermeer. ${ }^{362}$ Também desta exposição envio-te o catálogo. Além de Vermeer havia, na exposição, tantos outros pintores, de diversos países e épocas. Diz-se que os unia a mesma busca pela luz. Pelo menos assim dizem os organizadores da exposição. Não creio que possam compararse, por exemplo, às buscas de luz que Cézanne com aquelas de Vermeer. São antípodas. Uma pintura de raríssima qualidade de efeitos, como, por exemplo, la port sur la Marne a Créteil, extrai o seu prestigio, claro da luz, que reflete na água da paisagem, mas particularmaente do drama, que revelam os objetos, de querer conservar uma consistência de uma estabilidade volumétrica, que supere sua relevação momentânea obtida por um momento da luz fugitiva e da incessante mudança da água que no incessante movimento confere incessante diversidade de forma aos objetos. Outros problemas, daqueles de Vermeer, aos quais antes do impressionismo não se podia pensar, aliás aos quais não se podia pensar antes de Cézanne, que intorduz na representação pictórica o dramátice drama do objeto, se idealmente concebido no mesmo tempo se-posto em contraste com a sua percepção ótica que se pode ter, vista diferente de átimo em átimo pela diferente revelação da luz. ${ }^{363}$

361 UNGARETTT, Giuseppe. Vita d'un uomo. Tutte le poesie. Milano: Mondadori, (1969) 2009, p. 7.

362 Mais informações sobre a exposição presentes na carta anotada, no final desse capítulo.

363 Carta n. $^{\circ} 41$ 
Num ensaio de 1905, Jacques Félix Schnerb ${ }^{364}$ fala da construção de uma solidez nas pinturas de Cézanne e diz que isto viria da "sabedoria que ele colocou em modelar as superficies planas", e, assim, elabora um pouco mais sobre as distintas percepções de luz nas composições do pintor:

In rapporto all'occhio, supposto immobile, del pittore, i raggi luminosi provenienti da una qualsiasi superficie piana o no, sono tali che la somma di luce che l'occhio riceve non è la medesima per nessuno dei punti di quella superficie. Una superficie ci sembra avere unità di tono e di gradazione soltanto perché il nostro occhio si muove per percepirla tutta e se il pittore, per rappresentarla, stende uno strato monocromo sulla tela, la riprodurrà senza verità. ${ }^{365}$

Na observação de Schnerb, ao falar de Cézanne, luz também é cor. Essa è a mesma conclusão de Ungaretti quando fala de luz e cor em Vermeer, em seu ensaio de 1967. Escreve esse ensaio no calor dos anos em que acontece a correspondência com Bruna: em inúmeras cartas, ele descreve seu empenho para terminar aquele texto. Talvez seja ainda mais interessante observar, no próprio ensaio, os reflexos da presença de Bruna. Ungaretti observa que o pintor holandês carrega alguma herança de Piero della Francesca, seguindo os passos do crítico Roberto Longhi, dizendo, logo no início do seu texto: “[...] era católico e naqueles anos na Holanda talvez não fosse tão tranquilo assim, seguir $[\ldots]]^{366 ”}$. Começa "domesticando" o artista, para usar um termo tão caro à teoria da tradução. Uma herança italiana, uma crença compartilhada. Mas o que vai nos introduzindo ao pensamento de Ungaretti sobre o pintor - o que mais tarde se reflete também em seu olhar corriqueiro sobre o que há ao seu redor, como, por exemplo, a mobília na casa de Jean Paulhan —é em primeiro lugar a observação sobre as figuras que estão em cena, pintadas e representadas. Diz: "In Vermeer le figure non hanno né pretendono di avere maestá.” (p. 568). Entramos na dimensão do humano: para o poeta, aqueles que surgem nos quadros são pessoas que por hábito não saem dos limites prefixados que lhes são impostos, limites e ambientes que carregam simplicidade, mas isto não tolhe nada à profundiade, pelo contrário: “[...] può dare all'esperessione una giusta profondità, la giusta misura della profondità, quella misura che è indispensabile aiuto nel raggiungimento di un vero che non superi le misure della persona umana, che anzi si trovi, nei limiti stessi della persona umana" (p.586587). Também nesse ensaio, enquanto descortinamos as características da pintura de Vermeer, aprendemos sobre a poética e o olhar de Ungaretti, sua forma de imprimir a si

\footnotetext{
${ }^{364}$ DORAN, Michael. Cézanne Documenti e Interpretazioni. Bernard, Borély, Denis, Geffroy, Jourdain, Languier, Osthaus, Riviére, Schnerb, Vollard. Roma: Universale Donizzelli, 1998, p. 87-93.

365 Ibid. p. 90.

366 UNGARETTI, Giuseppi. Vita d'un uomo. Saggi e Interventi. Milano: Mondadori, 2001, p. 585, tradução nossa.
} 
mesmo em tudo o que observa, deixando, ao mesmo tempo, que o outro permeie o seu ser. E aos poucos o poeta vai se aproximando à questão da luz em Vermeer, ao escrever: "Lo dicono il pittore della luce. Dicono che cercasse la luce. Difatti cercava la luce. Si veda come essa vibri, per lui, dai vetri, come essa muova l'ombra, ombra della sua luce, ombra quasi impalpabile di ciglia mentre lo sguardo amato si socchiude, sguardo quasi nel suo protrarsi nella memoria e nel desiderio, imitasse il segno dell'ombra" (p. 588). Ungaretti observa que a luz em Vermeer carrega sempre consigo a sombra, um escurecimento parecido com o movimento dos olhos que se fecham, levemente, deixando espaço à penumbra. Há de se ter atenção ao falar de luz, diz Ungaretti: "Forse, cercando la luce, Vermeer trovava altro, forse la meraviglia sublime della sua pittura è nell'avere trovato altro" (p. 588). Fala do pintor ou de si? O fio condutor é quase sempre a luz: procurando-a, o que terá encontrado o poeta? O que terá encontrado evocando mia luce ao se referir à sua amada? "Tanti pittori hanno cercato di fermare la luce", muitos pintores tentaram capturar, deter, a luz, diz o poeta, e segue citando Caravaggio, Rembrandt, Pussin, Corot e Cézanne, dizendo sobre o último: "Cézanne considerava la luce in modo drammatico. Ha cercato di affermare, a dispetto e con rispetto della luce, il volume degli oggetti, gli sviluppi volumetrici che l'intelletto e la fantasia d'un pittore possono farsi suggerire dagli oggetti' (p. 589). Eis que podemos aqui aproximar a colocação de Schnerb sobre Cézanne - no que diz respeito à presença da cor na luz, ou do uso da cor para representar a luz — às observações de Ungaretti sobre Vermeer. Enfim, se buscando a luz, o pintor encontrou outra coisa, o que seria essa outra coisa?

Vermeer più che la luce ha trovato altro, ha trovato il colore, un colore vero, dato dalla sua assolutezza di colore. Se in Vermeer la luce conta, è perché anche la luce ha un colore, il colore di luce, e quel colore lo vede come un colore per se stesso, come luce, e ne vede, e ne isola, anche, se è vista, l'ombra, vincolo indissolubile della luce. ${ }^{367}$

A cor é luz e a sombra é, da luz, um vínculo indissolúvel. Como já mencionamos, é interssante olhar para o ensaio de Ungaretti, publicado em 1967, tendo agora em mente que, enquanto o escreve, o poeta também está escrevendo essas cartas a Bruna — seria este um dos motivos para dar um destaque especial ao quadro Mulher que escreve uma carta? Mais uma vez, a reflexão parece estar impregnada do biográfico, embebida da Vida de um homem. Ao falar da mulher retratada, ele se pergunta:

Cosa mai avrá da raccontare? La fronte spaziosa s'è volta un po' di lato, china verso gli occhi riflessivi. Cerca di connettere. Le si affollano in mente in troppi, i pensieri. Le dita si affusolano intento mostrando la

367 UNGARET'TI, Giuseppe. Vita d'un uomo. Saggi e Interventi. Milano: Mondadori, (1974) 2001, p. 589. 
grazia della mani carezzevoli che posano un pochino grassottelle, una in abbondono sul foglio, l'altra trattenendo la penna impaziente di tornare a vergare care frasi. ${ }^{368}$

O poeta passa da descrição do quadro, dos seus detalhes, para um aspecto mais abstrato e imaginado, tentando entender o pensamento da mulher retratada: “[...] come sarebbe meglio possibile di arrestare per sempre l'idea dell'assenza?" Qual seria a melhor forma de deter para sempre a ideia de ausência? Ungaretti parece embutir em sua pergunta as palavras de Erasmo de Roderdã: o que seriam as cartas se não uma correspondência entre ausentes? Porém, para o poeta, a ausência não é uma ideia angustiante, mas sim uma ideia "di infinita tenerezza d", com um leve sopro de melancolia. Ele diz: “[...] è la ricchezza della solitudine d'una giovine persona umana femminile, d'una giovine donna che guarda senza alcuna fissità né fissazione; ma con un dolce slancio salito dall'anima, l'assente persona, invocandola, senza disturbare il silenzio, accrescendolo all'infinito” (pp. 592-593). Do amarelo da roupa da mulher que escreve a carta, o poeta vai percorrendo outros quadros de Vermeer até chegar no fatídico muro que capturou a atenção de Proust, uma das últimas visões de Bergotte — "brandello di muro giallo" (p.594) — A vista de Delft, o quadro mais bonito do mundo segundo o escritor francês; e termina com as cores primariás, o azul e o vermelho de Vermeer: "[...] è tutto qui”" — ele diz — "ma mi pare che quel 'qui' sia una vastità' (p. 595).

Ungà se pergunta como é possível que Proust possa ter tido tamanha intuição e gosto, não só em relação aos seus contemporâneos, mas até em relação a "nós que vivemos quase meio século após a sua morte". Porém, talvez pudéssemos roubar essa observação e refletila no próprio poeta, um pouco como Carlo Ossola quando diz:

La poesia di Ungaretti comincia appena a nascere — "troppo tesa corda musicale" - alla nostra percezione di cittadini di una civiltà europea del XXI. Da Pascal a Bergson, da De Chirico a Fautrier, da Esenin a Pau Brasil, da Gongora a Shakespeare, quella parola è cresciuta dell'illimite dei deserti e degli abissi di coscienza. Appartiene al futuro. ${ }^{369}$

Esta palavra que cresceu entre os ilimitados desertos e abismos da consciência é palavra que pertence ao futuro, diz Ossola. Luz e escuridão também surgem no último Ungaretti, o poeta das cartas a Bruna, o mesmo que escreve o poema "Apocalissi", que fala de um horizonte de afasia e diz: "La verità, per crescita di buio/ Più a volarle vicino s’alza l'uomo, / Si va facendo la frattura fonda" — a verdade que se apresenta também pelo acréscimo

\footnotetext{
368 Ibid., p. 592.

369 OSSOLA, Carlo. Ungaretti, Poeta. Venezia: Marsilio, 2016.
} 
do escuro, quanto mais se aproxima o homem, mas funda se faz a fratura. Ao comentar seu próprio poema, Ungaretti escreve:

Tutto si accumula sullo stesso piano, e tutto questo presente accumulato forma una specie di buio dove non si distinguono neppure i connotati del proprio tempo perché il tempo va avanti con una veolocitá che non é di misura umana. Potrebbe essere questa l'apocalisse. ${ }^{370}$

\subsubsection{Fautrier, De Chirico, Savinio, Modigliani, Burri, Dorazio e Cagli}

Jean Fautrier ${ }^{371}$ é o artista plástico mais citado por Ungaretti neste conjunto epistolar: é mencionado em vinte e seis cartas a Bruna. Mais uma vez, como já mencionamos ao falarmos sobre Picasso e Cézanne, ao observarmos o olhar de Ungaretti para as outras artes, podemos colher alguns signos importantes dos temas que percorrem sua poética. A relevância da presença destes argumentos nas cartas dedicadas a Bruna está na possibilidade de conjugar a leitura dos relatos cotidianos aos ensaios escritos e publicados pelo poeta. Percorremos, de 1966 a 1969, o trabalho de Ungaretti na organização de sua obra completa, de seus ensaios, assim como de um dia a dia dinâmico desdobrado entre viagens, conferências e textos escritos para celebrações e catálogos. Para além das menções formais a Bruna sobre encontros e relatos do seu trabalho cotidiano, é possível destacar alguns momentos em que o poeta se entrega ao próprio pensamento e reflexão. Ao propormos uma leitura possível deste conjunto epistolar, tentamos oferecer esses relevos como percurso para conjugar a leitura a uma reflexão mais ampla sobre a obra e a poética de Giuseppe Ungaretti. Nossa principal ferramenta para trilhar este caminho foi a tradução e a anotação das cartas, após a primeira fase de transcrição dos manuscritos.

"La pittura de Jean Fautrier" 372 é um breve e importante ensaio assinado por Giuseppe Ungaretti sobre a obra do pintor, elaborado por ocasião da trigésima bienal de arte de Veneza, realizada em 1960. Durante esta bienal, a sala XXXVII do pavilhão central foi dedicada à uma vasta exposição de Fautrier, percorrendo, através de 130 obras, a história de sua pesquisa artística. Era um momento em que a chamada pintura informal se consolidava por toda a Europa, sendo considerada uma das manifestações artísticas mais significativas do pós-guerra. O comitê que organizou essa exposição era composto, entre outros, por Palma Bucarelli e pelo nosso poeta. Já vimos anteriormente, ao discorrer sobre a

\footnotetext{
370 UNGARETTI, Giuseppe. Delle parole estranee e del sogno d'un universo di Michaux e forse anche mio, in Vita d'un uomo. Saggi e interventi. Op. cit., pp. 842-844.

371 Para facilitar sua identificação, grifamos os nomes dos artistas plásticos nessa subdivisão.

372 UNGARETTI, Giuseppe. Vita d'un uomo. Saggi e Interventi. Op. cit., pp. 670-672.
} 
Carta n. ${ }^{\circ} 41$ do conjunto epistolar, a proximidade entre a crítica e galerista, Palma Bucarelli, e Ungaretti. Segundo a pesquisadora Giorgia Cicalini, ${ }^{373}$ foi o poeta quem propôs ao então presidente da Bienal de Veneza, Giovanni Ponti, que fosse organizada uma exposição individual do artista francês, conforme se lê na seguinte carta endereçada a Ungaretti:

[...] delle Sue sollecitazioni a favore di Fautrier, nei riguardi della prossima Biennale, è stato tenuto il massimo conto: non ho mancato infatti di far conoscere il testo della lettera al Comitato nella sua ultima riunione — facendo mio il Suo prezioso suggerimento - e posso ora dirLe che la mostra di Fautrier, da Lei proposta, è fra quelle in programma. [...] Mi fa molto piacere poterLe dare queste notizie e vedere avviato a felice conclusione quello che era un Suo voto. ${ }^{374}$

Já em uma de suas primeiras cartas a Bruna, quando introduz à amada seu amigo irmão Jean Paulhan, Ungaretti escreve: "[...] é verdade que escreveu só sobre Braque e Fautrier - mas de quem mais deveria escrever, os verdadeiros pintores dos últimos 50 anos se reduzem a estes dois nomes". ${ }^{375}$ O que impressiona o poeta, ao observar as obras do pintor francês - formado na Inglaterra - é justamente a sua capacidade de impor à arte características e beleza que são análogas ao que ocorre com os objetos submetidos às ações da natureza. Ainda que Ungaretti critique, num ensaio de $1927,{ }^{376} \mathrm{o}$ apego à materia presente no discurso dos futuristas, sua preocupação com a matéria pitórica está vinculada a como a ação da natureza e do tempo pode corrompê-la, e é esta a característica que parece excercer grande fascínio no poeta. "Non sono però i suoi dipinti, imitazioni della natura, ma sono come fossero vita vivente della natura, particolari casi nuovi, indimenticabili, della natura stessa", 377 escreve o poeta, sempre citando ter aprendido muito com a pesquisa de Bucarelli, autora de uma pequena monografia sobre o pintor. De fato, o pensamento do poeta, especialmente exemplificado por esta citação, parece caminhar pari passu com a descrição assinada por sua amiga e crítica:

$\mathrm{Ci}$ accade talvolta, in campagna, di smuovere un sasso e nel cavo di terra nuda vediamo con orrore un brulicare d'insetti, di vermi impazziti, che cercano di sfuggire, rientrando nella zolla nera, alla luce offensiva del sole. E non riusciamo a credere che lì, in quel minuto paesaggio di erbe brillanti e di fiori colorati, potesse celarsi quella vita buia di piccoli esseri mostruosi. Il sasso che Fautrier ha rimosso quasi distrattamente, per

${ }^{373}$ CICALINI, Giorgia. Palma Bucarelli e la Biennale di Venezia (1948-68): acquisizioni, prestiti e interventi critici della Direttrice della Galleria Nazionale d'Arte Moderna di Roma. 2015/2016. 156 pp. Tesi di Laurea — Università Ca'Foscari, Veneza, [s.d.] (http://dspace.unive.it/bitstream/handle/10579/9773/855482-1201030.pdf?sequence=2, consultado em 10/01/2019).

${ }^{374}$ Archivio Storico delle Arti Contemporanee (ASAC), Arti Visive, b. 92, Lettera di Giovanni Ponti a Giuseppe Ungaretti, 24 agosto 1959. Ibid., p. 96.

375 Carta n. ${ }^{\circ} 14$, datada de Paris, 18 de outubro de 1966.

376 UNGARETTI, Giuseppe. Commemorarione del futurismo. In Vita d'un uomo. Saggi e interventi. Milão: Mondadori, 2001, p. 172-173.

377 UNGARET'TI, Giuseppe. Vita d'un uomo. Saggi e Interventi. Milano: Mondadori, (1974) 2001, p. 670. 
sfiducia o per pigrizia, è la forma, il mondo che scopre con orrore, è il mondo senza luce, senza colore, senza contorni, senza alcuna delle qualita che ci fanno riconoscere la vita. ${ }^{378}$

Para Bucarelli, um dos grandes méritos de Fautrier é trazer à tona a vida submersa sob as pedras do jardim, ou seja, aquela vida que habita o escuro e que muitas vezes não se quer olhar. A coexistência de luz e escuridão, mesmo num sentido ampliado e metafórico, é um tema que surge nas observações de Ungaretti, mencionadas anteriormente, a respeito das obras de Vermeer. Outra observação do poeta em sua leitura da obra do pintor francês é um tema que recorre quando ele fala sobre os seus princípios de composição poética, ou seja, o domínio da técnica e a perlaboração. Fautrier é, com efeito, um dos primeiros expoentes da arte informal, porém, segundo Ungaretti, “[...] non si abbandona come un Pollock o un Wols, o chi vorrete, a um automatismo psichico, ma (...) ricorre a un operare voluto" (p. 670-671). Mais uma vez, o poeta destaca como qualidade noutro artista algo que faz parte da sua busca constante, de sua própria forma de operar no âmbito do fazer poético. Para Ungaretti, os resultados alcançados por Fautrier não são ditados por um estado de sonambulismo, tampouco são fruto de um efeito fortuito propiciado pelos materiais utilizados, mas sim um processo em ação, operado pela "lucidità d'intelletto" (p. 671). Partindo de sua observação primária das pinturas, Ungaretti continua, no seu texto de 1960 dedicado ao pintor, em busca das razões da arte de Fautrier, já que "arriva sempre il momento di cercare ragione alle cose" (p. 671). Assim como o poeta reflete sobre as razões de sua poesia, busca o mesmo enredo na arte que corresponde às suas predileções. O milagre de Fautrier é, para o poeta, "miracolo di volontà e di straordinaria perizia controllata d'occhi e di mano", e o que ele aprecia e escreve sobre o pintor parece ecoar em cada conselho que ele destina à jovem poeta, sua amada Bruna. Como aponta Ossola, Ungaretti é o poeta da palavra esculpida entre o deserto e o abismo do silêncio. Essa precisão é a superfície que serve como espelho, e sobre ela Ungaretti se reflete e pondera ao observar Fautrier; a pintura que tira o fôlego não provoca grito, mas reduz o observador “al silenzio per contemplare e godere il miracolo" (p. 671). O poeta carrega nas entrelinhas da observação o magma do seu poema "Commiato", "poesia/ è o mundo a umanidade /a vida em si/ florescidos pela palavra/ a límpida maravilha / de um delirante fermento/

378 BUCARELLI, Palma. Jean Fautrier: pittura e materia. Milão: Il Saggiatore, 1960, p. 38-39. 
Quando encontro/ neste meu silêncio/ uma palavra/ é escavada em minha vida/ como um abismo". 379

Fautrier é um dos artistas que decora o quarto do poeta. São muitas as descrições minuciosas nesse longo compêndio epistolar. Há inúmeras descrições de quartos de hotéis, de pessoas que frequentam os lugares onde o poeta se encontra, mas há também algumas descrições bastante especiais do espaço da intimidade onde ele cria, escreve e trabalha. Numa delas, podemos encontrar seus artistas prediletos, como se lê na Carta n. ${ }^{\circ} 71$. Nesses anos, Ungaretti se dividia entre a casa da filha e do genro, na rua Sierra Nevada, em Roma, e o Hotel dei Congressi, ambos logradouros situados no bairro EUR. Isso quando não estava viajando pela Itália ou pelo mundo. Ungaretti nos conta:

O que faço? Penso em ti, e me pergunto o que farás tu [...], às $4 \mathrm{da}$ tarde em Roma. Eu estou em casa, à minha mesa de trabalho, diante de uma porta de vidro que se abre para um terraço que circunda a casa, no $4 .^{\circ}$ e último andar. Estou circundado por livros, por um lado aqueles que já não sei onde colocar, duas gravuras de Rembrandt da primeira tiragem, um Burri, dois Fautrier, e em cima da cama (de dia sofá) uma nossa senhora bizantina, e um crucifixo jansenista. A cama é uma caminha de campo, sempre dormi em camas pequeninas, e num quarto onde não havia outros hóspedes, pois trabalho até tarde, até o dia raiar, pelo menos antigamente era assim, agora trabalho sobretudo de dia. ${ }^{380}$

Para acompanharmos Ossola, quem observa que a palavra poética de Ungaretti pertence ao futuro, damos ainda mais um passo adiante, pois alguns de seus pensamentos também pertencem ao nosso presente. As observações que tece ao concluir o ensaio sobre Fautrier parecem arremessar o leitor de então - 1960 - ao futuro, ou seja, ao nosso presente. Seguindo a trilha das metáforas de luz e sombra, relembramos aqui Agamben em seu ensaio "O que é o contemporâneo", antes de avançarmos um pouco mais para analisarmos o pensamento de Ungaretti. Agamben afirma:

O poeta - o contemporâneo - deve manter fixo o olhar no seu tempo. Mas o que vê quem vê o seu tempo, o sorriso demente do seu século? Neste ponto gostaria de lhes propor uma segunda definição da contemporaneidade: contemporâneo é aquele que mantém fixo o olhar no seu tempo, para nele perceber não as luzes, mas o escuro. Todos os tempos são, para quem deles experimenta contemporaneidade,obscuros. Contemporâneo é, justamente, aquele que sabe ver essa obscuridade, que é capaz de escrever mergulhando a pena nas trevas do presente. Mas o que significa "ver as trevas", "perceber o escuro381"?

\footnotetext{
379 Tradução nossa do poema original: "Gentile/Ettore Serral poesia/ è il mondo l'umanital la propria vital fioriti dalla parolal la limpida meraviglia/ di un delirante fermento/Quando trovo/in questo mio silensio/ una parola/ scavata è nella mia vita/ come un abisso". In Vita d'un uomo. Tutte le poesie.

${ }^{380}$ Carta n. $^{\circ} 71$.

381 AGAMBEN, Giorgio. O que é o contemporâneo? e outros ensaios. Trad. Vinícius Nicastro Honesko. Chapecó: Argos, 2009, p. 62-63.
} 
O caminho que Ungaretti trilha ao refletir sobre a sua própria poética parece acompanhar a observação de Agamben: o que o poeta vê refletido na pesquisa de Fautrier também diz respeito à sua postura poética. Nos últimos parágrafos do texto que apresenta a monografia de Bucarelli sobre o pintor francês, o poeta observa um movimento que acomete a humanidade, ou seja, uma progressiva dissolução dos espaços, das dimensões e do tempo até o ingresso numa desmedida apocalítica. Ele diz:

\begin{abstract}
Se l'uomo si dilata, sino a abolire il proprio spazio, le sue dimensioni, $\mathrm{i}$ propri connotati e lo spazio; sino ad avere spavento del tempo e dei caratteri del tempo incessantemente e innumerevolmente mutevole nei suoi sengi, e nel perire; sino ad avere paura della memoria da cui nascono di continuo strumenti, i sempre più terribli mezzi che l'uomo e la sua memoria non sanno più dominare se non per esserne travolti - se in giro c'è una dismisura da Apocalisse, come il pitture (la pittura può, come ogni linguaggio essere linguaggio oesesnziale, linguaggio di poesia), come il pittore ne troverà misura liberatrice nella sua arte?382
\end{abstract}

Então, a partir desse cenário, como deve o artista encontrar uma medida, em sua arte, que possa libertá-lo deste jugo? Qual seria a resposta de Fautrier — e qual a de Ungaretti, espelhado no pintor? Perante a dissolução, a única resposta possível, para o poeta, é o deslocamento do artista, o qual deve sondar o universo dentro de suas próprias vísceras antes de gerar uma resposta. "Tocherebbe di manifestarsi come se nelle sue viscere avesse sondato l'universo, e dell'universo avesse passato in rassegna, esamiandoli alla lente, in uno baleno gl'infiniti aspetti, e come se, di tale conoscenza terrificante che l'anima, dovesse dare una sitesi non disumana" (p. 672), a mesma busca de um Barroco harmonizante. Ungaretti encontra em Fautrier a crítica do que lhe parece faltar na obra de Picasso, mesmo reconhecendo toda a grandeza do artista espanhol. Como forjar uma síntese não desumanizada diante de tamanha dissolução de fronteiras entre tempo e espaço? Trata-se de um tema bastante recorrente em Ungaretti, sobretudo enquanto leitor de Leopardi, essa questão da razão e da modernidade como incapazes de responder às grandes questões e direções do presente.

Fautrier também ressurge com Blake, Turner e Vermeer num passeio no museu Tate - tematizado da Carta n. ${ }^{\circ}$ 165, datada de 12 de julho de 1967 - durante sua passagem por Londres por ocasião da leitura organizada por Ted Hughes. Sua tradução de William Blake, Visioni di Blake, fora publicada dois anos antes. Eis como o poeta observa a filiação da pintura de Fautrier, com passagens por Vermeer e Turner:

Esta manhã estive na Tate Gallery, para ver os desenhos e as pinturas de Blake. Que surpresa, que, das ilustrações de Blake reproduzidas em

382 UNGARETTI, Giuseppe. Vita d'un uomo. Saggi e Interventi. Milano: Mondadori, (1974) 2001, p. 672. 
impressão eu não conseguira ter. Com Turner, o último Turner, o Turner sem outra cor, o Turner que há mais de um século tve a coragem, primeiro, de não ser mais um pintor acadêmico, mas livre, só pintor, só poeta expressando-se na pintura, com Turner e Blake eu descobria as origens da pintura informal.

Os primeiríssimo precursor fora Vermeer. São os pais do maior pintor da segunda metade do século XX, de Fautrier. Fautrier era, enfim, por parte de mãe, metade inglês, e havia estudado na Inglaterra. ${ }^{383}$

O pesquisador Francesco Sielo ${ }^{384}$ escreveu sobre a convergência de uma estética apocalítica na poética de Ungaretti e em alguns artistas seus contemporâneos, como Fautrier e Burri. Sielo cita a série Otages ("Reféns") de Fautrier, na qual o trabalho, ainda que centrado na materialidade, possui um tema de fundo que o transcende, ou seja, a sua condição. Segundo Palma Bucarelli, "la condizione dell'ostaggio [...] è latente nella condizione umana, è una delle condizioni-limite dell'uomo moderno com'è pensato dalle filosofie esistenzialiste". ${ }^{385}$ Se, por um lado, o poeta não endossa o que chama de monstruosidade nas representações de Picasso, ainda que o reconheça como um mestre, em Fautrier ele parece encontrar algo de um gesto que se esforça por encontrar uma medida, uma reconexão, nas palavras de Sielo: "la ricerca artistica di Fautrier è rivolta a un oggetto artistico che in qualche modo renda misurabili e ricolleghi al soggetto umano le nuove dimensioni di spazio e tempo come sono esperite nella contemporaneità". ${ }^{386}$ Assim como Fautrier busca a possibilidade de uma expressão frente à percepção de um espaço e de um tempo colocados em crise, Ungaretti também dirige o mesmo questionamento à poesia: “esiste ancora la possibilità d'un linguaggio di poesia? Oggi il tempo è divenuto tanto veloce che pare non esista più la possibilità di rapporto tra tempo e spazio, che pare non esista più durata, cioè non esista più possibilità di contemplazione $\mathrm{e}$, per conseguenza, di espressione di poesia." ${ }^{387}$

Braque é outro artista que surge nas cartas de Ungaretti, mas sempre conjugado a algum outro nome, sendo citado quando o poeta fala sobre Fautrier ou Picasso. Ungaretti vai elaborando, ao longo das cartas, algumas listas informais em que desenha uma escala de valor artístico para escritores, musicistas e artistas plásticos. Ainda assim, é importante relembrar a menção feita a Braque na versão de 1957 do seu texto "Difficoltà della

383 Carta n. $^{\circ} 165$, datada de 12 de julho de 1967.

384 SIELO, Francesco. Ungaretti e l'arte informale: l'ossessione apocalittica della materia. La letteratura italiana e le arti. Atti del XX Congresso dell'ADI - Associazione degli Italianisti (Napoli, 7-10 settembre 2016). A cura di L. Battistini, V. Caputo, M. De Blasi, G. A. Liberti, P. Palomba, V. Panarella e A. Stabile. Roma: Adi editore, 2018

(http:/ / www.italianisti.it/Atti-diCongresso?pg =cms\&ext=p\&cms_codsec=14\&cms_codcms=1039, consultado em 10 de dezembro de 2018).

385 Ibid., p. 3 e BUCARELLI, Palma. Jean Fautrier: pittura e materia. Milano: Il Saggiatore, 1960, p. 82.

386 Sielo, Francesco. Op. Cit., p. 3

387 Citado por Sielo, ibid. Texto na íntegra: Ungaretti, Giuseppe. "Difficoltà della poesia (1952\1963)". Vita d'um uomo. Saggi e Interventi, ob. Cit., p.792-814. 
poesia"388 que incluia um último parágrafo (eliminado na edição de 1963) no qual o poeta destacava artistas cujo canto era visto, por ele, como puro e trágico: "Così, tra tanti artisti d'oggi, sono arrivati a snodare qualche volta cant itragici e puri Valéry e Mahler, Braque e Kandinsky [...] Avere luce nel cuore è difficile, soffrire e morire non sono che la sorte di tutti ${ }^{389}$ ". Braque também é relembrado na Carta n. ${ }^{\circ} 332$, datada de dia 27 de outubro de 1968, em que diz ter sido ele, ou talvez Robert Delaunay, quem lhe mostrou esculturas africanas - Ungaretti passaria então a colecioná-las. Há nomes que surgem, como os de Braque, Modigliani, De Chirico e Savinio, como pretexto para resgatar lembranças e um pouco da vida vivida nos anos de Paris, essa riqueza eternizada na vida do poeta.

Ungaretti diz logo numa das sua primeiras cartas à amada: "sono un parigino ostinato, e un viaggiatore ostinato". Ele é, com efeito, um parisiense e viajante obstinado, e isso fica ainda mais claro a cada carta lida. Ele é também "L'affricano a Parigi", sendo esse o título de um poema em prosa do livro L'Allegria. Mais adiante, falaremos um pouco da relação do poeta com a capital francesa, como uma das cidades mais visitadas durante o período de troca com Bruna Bianco, mas também como sua segunda casa. Não é raro ler algo como o que lemos na Carta n. ${ }^{\circ} 14$ :

Deveria te falar de Paris, desta área em que moro, que é a área das faculdades, dos estudantes, dos editores, das grandes e pequenas revistas literárias de todo tipo, da arte, e de todas as loucuras que há muitíssimos anos nascem no mundo para demonstrar-lhe que o ser humano não está morto. Encontrei-a num estado desperto e magnífico. ${ }^{390}$

Ou ainda, outras descrições poéticas sobre a cidade, como na Carta n. ${ }^{\circ} 22$, em que ele diz que ficará muito feliz por caminhar com sua amada por Paris, "a cidade que conheço melhor e que é a mais surpreendente de todas". ${ }^{391}$ Mas há uma parte da história do poeta a que ganhamos acesso nas pequenas referências que surgem nas entrelinhas do cotidiano. Assim é com relação a Modigliani, cuja amizade com Ungaretti se consolidou nos anos em que ambos viviam em Paris. O poeta lembra-se de que o amigo morreu no ano de seu casamento com Jeann Dupoix, depois descreve brevemente o encontro na nota de introdução à sua obra poética Vita d'un nomo:

Abitavamo in rue Campagne Premiére. C'era in quella strada allora una trattoriuccia, gestita da una donna anziata chiamata dai clienti la Mère Rosalie. Ai pasti, vi incontravo quasi ogni giorno Modigliani. Arrivava

\footnotetext{
388 UNGARETTI, Giuseppe. Difficoltà della poesia (1952/1963). Vita d'um uomo. Saggi e Interventi. Ob. cit., p. $792-$ 814.

389 UNGARET'TI, Giuseppe. Vita d'um uomo. Saggi e Interventi, ob. Cit., p.1014

390 Carta n. ${ }^{\circ} 14$, datada de 18 de outubro de 1966.

391 Carta n. $^{\circ} 22$, datada de 27 de outubro de 1966.
} 
con la sua giovanissima donna, fasciata l'esile persone in una dedingote dal lungo garbo di velluto azzurro elettrico. ${ }^{392}$

Modigliani não fazia muito caso à comida, segundo Ungà, estava sempre encurvado a desenhar, "non smetteva di disegnare la gente che era lì, quanto gli balenasse in mente, e lasciava sulla tavola quei pezzetti di disegni che poi furno venduti, penso dalla proprietaria del locale" (p. 476). Pouco tempo após o início dessa amizade, o poeta recebe a notícia do adoecimento do pintor de Livorno e a seguir de sua morte. $\mathrm{Na}$ Carta n. ${ }^{\circ}$ 72, datada de 31 de dezembro de 1966, Ungaretti responde à amada, confortando-a por algum luto sofrido, e diz sentir aquela dor como se fosse a sua própria, e então relembra a morte do amigo:

Lembro, no túmulo de Modigliani — éramos só em cinco a acompanhálo, logo após a primeira guerra, em Paris — o Rabino que lia o texto bíblico: "Deus deu, Deus tirou". Ninguém tinha convidado aquele rabino, Modigliani não praticava sua religião, tinha aparecido por conta própria e fez muito bem. ${ }^{393}$

Do gesto relembrado e narrado nesta carta, emerge algo fundamental do caráter desse poeta, certamente um dos maiores nomes do século XX, não só na poesia italiana, mas na literatura mundial: a sua presença íntegra. O poeta e ensaista Davide Rondoni comentou a respeito das cartas endereçadas à amada:

Cosa fa un uomo anziano, il giorno dopo di Natale nel 1966 in una Roma gelata, all'ufficio centrale delle poste, presso "l'unico sportello da cui si possa mandare qualcosa"? Manda lettere, cataloghi, profumi... È un demente d'amore, è uno dei soli cinque uomini che era al funerale di Modigliani a Parigi, un uomo che a Natale del 1916, cinquanta anni prima, invitato in una casa, dormi per terra invece che a letto, assuefatto alla trincee. ${ }^{394}$

O mesmo homem que no Natal ou no último dia do ano se desloca até o correio central da capital italiana para enviar cartas à amada é o que está, entre um punhado de gente, presente no funeral do amigo, a quem conhecera pouco tempo antes, nas mesas de um pequeno restaurante de bairro em Paris. Assim, ressurge sempre Paris e ressurgem seus encontros: a vida é sempre rememorada nestas cartas, a noção de tempo desloca-se nesse sentido — não se trata apenas do presente da escrita mas também do passado que se presentifica, pronto para ser entregue à escuta de Bruna.

Outra lembrança notável é a descrição de Ungaretti ao entrar no quarto de André Breton. Ele conta que um dia, no início do século XX, entrou no quarto de Breton e surpreendeu-o enquanto tentava juntar vários pedaços de papel rasgado: tratava-se de

\footnotetext{
392 UNGARETTI, Giuseppe. Vta d'un uomo. Tutte le poesie. Milano: Mondadori, 2009, p. 746.

393 Carta n. ${ }^{\circ}$ 22, datada de 31 de dezembro de 1966.

${ }^{394}$ RONDONI, Davide. Ungaretti e la verità in amore (https://www.avvenire.it/agora/pagine/ungaretti, consultado 17 de setembro de 2017).
} 
desenhos de Modigliani. Ungaretti diz: "[...] un giorno ve lo incontrai che tentava di mettere in sieme dei pezzettini di carta, e tutt'intorno c'era una grande confusione", depois continua: “un'amica gelosa gliaveva, nella sua rabbia, strappato i disegni di Modigliani che, fissati accuratamente con chiodini alle pareti, gli avevano per tanto tmepo tenuto compagnia". ${ }^{395}$ Há nas cartas a Bruna a coexistência entre memória e inocência: se, de um lado, o sentimento amoroso, a escuta e a novidade do amor remetem à inocência e ao desconhecido da vida, há por outro lado uma ação contínua de rememoramento, uma narrativa íntima da construção de sua obra reunida.

De Chirico e seu irmão Savinio também aparecem nos relatos a Bruna. Já na sua introdução à poesia completa, ao re-percorrendo sua vida, Ungaretti escreve sobre o encontro com o pintor. Relembramos que, em 1969, sai a primeira edição do volume de poemas Vita d'un uomo, ou seja, sua poética obra reúnida. $\mathrm{Na}$ Carta n. ${ }^{\circ} 180$, datada do início de agosto de 1967, podemos conjeturar, novamente, que uma das funções da escrita epistolar foi também a busca de uma escuta generosa para relatar novamente a sua trajetória. Assim, entre os afazeres do cotidiano e os planos do futuro, ressurgem lembranças do passado, sobretudo dos anos vividos em Paris e nos arredores de Roma. Ungaretti relembra: "De Chirico l'ho conosciuto dopo la guerra, ma sono forse stato il primo italiano a conoscere direttamente le sue Piazze scoperte con stupore da Apollinaire al Salon des Indépendants, che portò poi ai sette cieli", ${ }^{396}$ referindo-se, provavelmente, à colocação de Apollinaire no jornal L'Intransigeant, ${ }^{397}$ que em 1913 escreveu: "L'arte di questo giovane pittore è un'arte interiore e cerebrale che non ha alcun rapporto con quella dei pittori che si son rivelati in questi ultimi anni. Non viene né da Matisse né da Picasso, e non deriva dagli impressionisti." ${ }^{398}$ Ungaretti também relembra De Chirico quando comenta seu próprio livro Sentimento del Tempo, a propósito de uma harmonização entre a invenção e a tradição. Justificando o eco dos clássicos em seus versos e fazendo também um comentário sobre o pintor, ele escreve: "De Chirirco, ormai ricerca in Giotto il carattere della sua pittura" ${ }^{399}$ Ressoa entre uma carta e outra a explicação de Ungaretti sobre sua escolha Vita d'un nomo como título para reunir sua obra, em Ungaretti commenta Ungaretti ${ }^{400}$ (1963), ele escreve: "il carattere, il primo carattere di tutta la mia attività è autobiografico" (p. 815). A primeira característica de sua obra é o autobiográfico, e assim observarmos a trama delicada

\footnotetext{
395 UNGARETTTI, Giuseppe. Vita d'un uomo. Saggi e Interventi. Milano: Mondadori, (1974) 2001, p. 657. 396 UNGARETTI, Giuseppe. Vita d'un uomo. Tutte le poesie. Milano: Mondadori, 2009, p. 474.

397 Jornal francês publicado entre 1880-1948 fundado por Henri Rochefort.

398 APOLLINAIRE, Guillaume. L'Intransigeant, 9 de outubro de 1913 (https://gallica.bnf.fr/ark:/12148/bpt6k7868718/f3.image.r=de\%20chirico? rk=21459;2, consultado em 20 de janeiro de 2019).

${ }^{399}$ UNGARETTTI, Giuseppe. Vita d'un uomo. Saggi e Interventi. Milano: Mondadori, (1974) 2001, p. 824.

${ }^{400}$ UNGARETTI, Giuseppe. Vita d'un uomo. Saggi e Interventi. Milano: Mondadori, (1974) 2001, p. 815.
} 
de lembranças que vão surgindo como livre associações enquanto - entre uma atividade e outra - ele se senta para escrever à amada. Ungaretti se lembra de Savinio e De Chirico justamente ao mudar a disposção de duas pequenas poltronas em seu quarto, para receber seu assitsente e trabalhar na preparação do volume dos seus ensaios, selecionando o que fará e o que deixará de fazer parte do cânone. Começa com a descrição do seu quarto:

Tenho um quartinho de quatro palmos, mesmo o de Londres era uma cela de monge, e está todo ocupado pela cama, por uma mesa grande eø com tapete verde, e por outra mesinha em que apoio os enormes dossiês. Há, além disso, duas pequenas poltras vermelhas, como os que serviam para Savinio ${ }^{401}$ para acomodar, em suas pinturas, a mãe, um pouco transformada em peru, e de fato, tinha um rosto um pouco daquele jeito. Não que ele não amasse e respeitasse sua mãe, mas naquele nosso tempo o respeito e o amor não eram livres nem diminuidos por um pouco de humor. 402

A jocosa associação das poltronas vermelhas serve como pretexto para falar de Alberto De Chirico, mais conhecido como Alberto Savinio. Conta o poeta: "Savinio, como sabes, era o irmão de De Chirico, e talvez tivesse mais engenho, mais imaginação, mais ideias e mais comoção do que ele. Nos meus belos anos foi como um irmão para mim, agora descansa ele também num cemitério". ${ }^{403}$ Savinio morre em 1952, e dele Ungaretti recorda o romance de estreia Hermaphrodito, em seu texto "La doctrine de 'Lacerba", ${ }^{404}$ não havendo, porém, outros comentários dele. Acreditamos que a observação de Ungaretti seja ligada também à polivalência artística de Savinio, menos projetado do que o irmão Giorgio, mas cuja obra merece ser relembrada e quiçá também traduzida para o português. Uma das funções que emerge desse compêndio epistolar é justamente esta abertura que o poeta provoca em cada leitor: para além das juras de amor ou do desejo de participar a Bruna a literatura e a cultura europeias, há, nessas cartas, a possibilidade de se perder no que seria o cânone ungarettiano e, a partir dessas indicações seguir, avançar, traduzir. Enfim, ele conclui a sua reflexão sobre Savinio apontando novamente à finitude: ainda que o futuro e o presente pareçam expandidos nestas narrativas, há o inéxoravel fim: "Dos meus coetâneos, do meu tempo, quem sobrou? Túmulos, túmulos, túmulos!" 405

Burri, Dorazio, Manzù e Cagli são os artistas com quem Ungaretti colaborou e, por esse motivo, eles também surgem nas cartas à amada. Burri ocupa, entre os demais,

\footnotetext{
401 Alberto Savinio (1891-1952) escritor, pintor e compositor italiano, irmão de Giorgio De Chirico, nascido na Grécia, onde se criou até os catorze anos.

402 Carta n. ${ }^{\circ} 180$.

${ }^{403}$ Carta n. $^{\circ} 180$.

404 UNGARETTI, Giuseppe. Vita d'un uomo. Saggi e Interventi. Milano: Mondadori, (1974) 2001, p. 45.

405 Carta n. ${ }^{\circ} 180$.
} 
uma posição privilegiada, pois ilustrou, com uma combustão, o livro Dialogo. Seu nome surge pela segunda vez neste volume quando o poeta dá a notícia da colaboração à jovem amada: “[...] e depois haverá o teu e meu livro em 1968 com as gravuras de Burri, o maior entre os vivos, exceto Picasso". 406

Ungaretti, como já observamos anteriormente, adora fazer listas e colocar em primeira, segunda e terceira posição os artistas e escritores que conhece. No dia 29 de junho, por exemplo, ele volta a falar de Burri, colocando-o entre os três maiores artistas italianos:

Os italianos ótimos, e considerados ótimos também no exterior, são hoje três: Burri, primeiríssimo, muito doente, viajou para Boston onde deve fazer uma cirurgia delicada [...]. Cagli e Dorazio. Tem também o Schifano. Mas deveria se tornar um pouquinho mais sério. ${ }^{407}$

O nome do amigo e colaborador surge também mais adiante na Carta n. ${ }^{\circ} 173$, quando o poeta confirma à amada que a cirurgia do amigo correu bem; e, por fim, volta a falar do livro que, entre muitas correções, vai ganhando corpo. Aqui há um aceno de interesse de Ungaretti pelas combustões do autor: até então falava-se de gravuras para o livro, e ele diz à sua amada: “[...] tenha orgulho, é um fato estupendo, memorável, invejável, só poucos eleitos puderam gozar de algo semelhante na história", e continua: "Há um álbum [...] um album estupendo de queimaduras de Burri. Espero poder enviá-lo ou levá-lo até ti." "408 Sabemos que a escolha final é uma combustão, essa "queimadura", talvez a melhor escolha para ilustrar esse encontro. No final da mesma carta, em letras garrafais, Ungà rascunha alguns versos que parecem imprimir alguma qualidade do fogo, sua ação que destrói, mas também transforma, transmuta: "VIVO E MUOIO E/ RIVIVO E MUOIO ANCORA /E VIVO SEMPRE PER SEMPRE /D'AMORE PER TE” — "vivo e morro / revivo e morro de novo / e vivo sempre para sempre/ de amor por ti". ${ }^{409}$ Há que se lembrar que a última comunicação do poeta com sua amada foi enviando-lhe uma edição especial e de luxo do livro Il Dolore, em cuja dedicatória ele afirma que seu amor por Bruna ainda arde sob as brasas do coração. Apresentamos aqui uma reprodução da combustão número 13 do livro Dialogo:

\footnotetext{
406 Carta n. ${ }^{\circ}$ 130, datada de 7 de março de 1967.

${ }^{407}$ Carta n. $^{\circ} 155$.

${ }^{408}$ Carta n. ${ }^{\circ} 188$, datada de 12 de agosto de 1967.

${ }^{409}$ Ibid.
} 


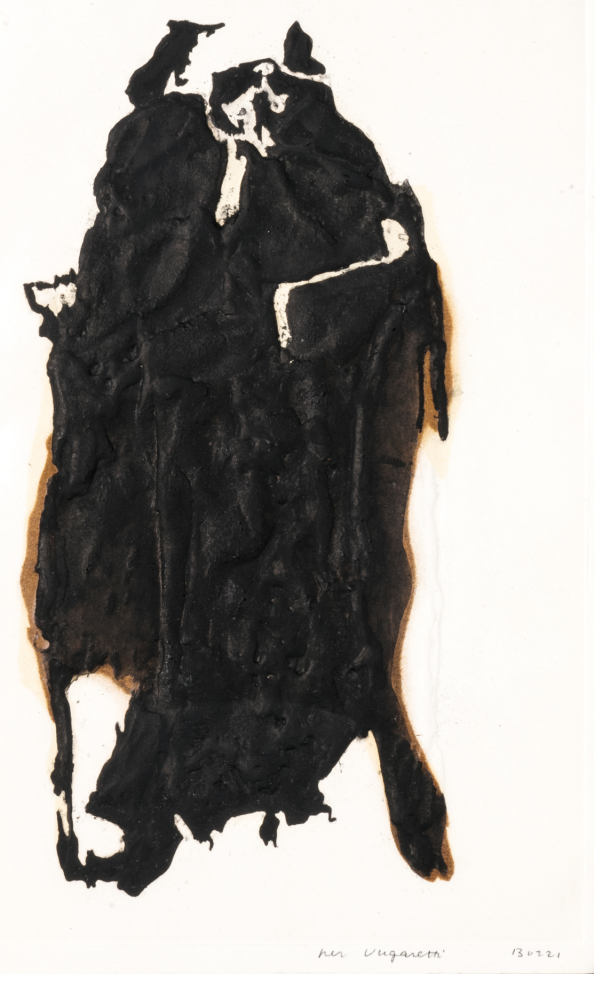

No ensaio "L'amore non è giusto", ${ }^{410}$ o poeta Davide Rondoni tece uma metáfora para falar do amor e do encontro entre dois sujeitos usando a imagem do fogo. Parece-nos apropriado para pensar a publicação do livro Dialogo, assim como o próprio encontro entre Ungaretti e Bruna. Rondoni escreve: “[...] os amores, muitas vezes, se assemelham às pilhas de lenha que aparentemente não estão em chamas, mas uma língua de fumaça nos adverte que há certa combustão", e continua: “a poesia — uma arte de gente faminta, e muitas vezes gulosa — não se ocupa com frequência destes tipos de fogos menos visíveis", ou seja, os fogos que "com aquela ardência lentamente tornar-se-ão brasa, deixando cinzas, carvão, minerais, alimento". ${ }^{411}$ A matéria do amor dos poetas, Ungà e Bruna, é poesia e combustão: explosões temperadas por distância e escrita. Cada clarão — poemas, traduções, viagens — imprime sombras. A luz do encontro, projetada sobre os corpos, desenha

\footnotetext{
410 A citação é retirada do manuscrito do livro, em Word, entregue-me pessoalmente pelo autor em 2013, está na página 115, mas já editado o livro tem a seguinte referência: RONDONI, Davide, L'amore non è giusto, Forlì: Carta Canta Editore, 2013, traduções nossas dos seguintes trechos em italiano: "Gli amori spesso somigliano alle cataste di legna che apparentemente non sono infiammate, ma una lingua di fumo ci avverte di una certa combustione. E magari lentamente quell'ardere diverrà tizzoni, lascerà cenere, carbone, minerale, nutrimento. La poesia -un'arte per gente affamata, e spesso golosa- non si occupa spesso di tali fuochi meno visibili" (p.115 no manuscrito, p. 83 no livro publicado) e "Una vampa di fuoco può illuminare e farci comprendere dove siamo. Darci una rivelazione istantanea. Può proiettare sul muro del vivere consueto la nostra ombra e farci accorgere di quale posizione abbiamo. Ci può far vedere per un istante il volto nostro e altrui con una precisione mai avuta prima, suscitando sgomento" (p. 121 no manuscrito, pp. 86-87 no livro publicado).

${ }^{411}$ RONDONI, Davide, L'amore non è giusto, Forlì: Carta Canta Editore, 2013, p.115.
} 
sombras e siluetas - como na caverna de Platão — a cada clarão há uma aproximação à imagem de si. Escreve Rondoni:

[...] uma labareda de fogo pode iluminar e nos fazer entender onde estamos. Dar-nos uma revelação instantânea. Pode projetar no muro do comum viver nossa sombra nos fazer entender qual posição assumimos. Pode por um instante nos mostrar o nosso rosto e o do outro com tamanha precisão nunca experimentada, sucitando consternação. ${ }^{412}$

Ungaretti desloca-se sempre, no presente da escrita epistolar, para o passado e para o futuro numa mesma epístola. $\mathrm{Na}$ Carta n. ${ }^{\circ} 190$, por exemplo, enquanto conta que quer presentear Bruna com uma de suas obras preferidas de Fautrier, relembra que com esteve com o artista no Japão, antes mesmo de conhecê-la. Envia-lhe algumas fotos da viagem passada, fazendo-a participar assim do seu passado, e escreve que talvez só Burri poderia ser o outro artista amado e compreendido pelos japoneses:

[...] os japoneses - lembras que estivemos juntos no Japão — têm uma longa tradição, e uma habilidade fora do comum com o artesanato, se surpreendiam diante do seu trabalho. Creio que na Europa fosse o único a surpreendê-los. Talvez os surpreendesse o trabalho de Burri, se o vissem. Mas o que é que não conhecem os japoneses? Sabem tudo de tudo. ${ }^{413}$

Há também, evidentemente, a necessidade de engrandecer aos olhos da amada o valor do artista que participará da edição do livro.

A vontade inicial do poeta era incluir, entre os poemas, também algumas cartas, alguma prosa trocada entre os dois. Podemos conjecturar que havia um desejo subjacente de tornar pública pelo menos uma parte do acervo epistolar — há de relembrar a missiva em que Ungà comenta quanto valeria esse conjunto de cartas para alguma universidade norte-americana. Ramat é categórico ao apontar que o compêndio de cartas não é uma “obra de arte ${ }^{414}$ — "sarebbe innegabilmente una forzatura”. Nós, pelo contrário, nos interessamos muito mais pela palavra obra, por toda a riqueza que o vocábulo encerra, especialmente ao se escrever sobre Giuseppe Ungaretti. Para um poeta cuja obra reunida se intitula Vita d'un nomo, para um poeta que escreve, com todas as letras, que sua escrita sempre foi atravessada pela questão biográfica — ou seja, o homem que inscreve sua vida na obra — não seriam estas as cartas, também, uma obra? Defendemos justamente essa outra interpretação, ou seja, defendemos a interpenetração entre vida e obra, algo sempre presente em Ungaretti. Propondo aqui uma leitura que deixe os contornos dos gêneros mais

\footnotetext{
412 Ibid. 121

${ }^{413}$ Carta n. ${ }^{\circ} 190$, datada de 16 de agosto de 1967.

414 Prefácio de Silvio Ramat, in UNGARETTI, Giuseppe. Lettere a Bruna. Milão: Mondadori, 2017, p. IX.
} 
brandos, pensamos nesse compêndio como algo que cruza tanto a ficção quanto o autobiográfico. A escrita de Ungaretti nessas cartas é múltipla e rica como raramente se leu em outras correspondências: o amor é a capa freática, o leito do rio que nutre o todo, é o motivo, e o leitmotif, das cartas — mas há tantos outros múltiplos gêneros aqui: há tradução, há poesia, há crônica, há a escrita de um diário.

Tentamos, portanto, nos tanto distanciar de Ramat, que cincunscreve o compêndio epistolar à mera temática amorosa — fato inegável — quanto de Sanavio, ${ }^{415}$ que, ao se ver descrito num diálogo íntimo entre dois amantes, acusou o voyeurismo editorial — "sem comentários" - da editora Mondadori. Nossa posição é privilegiada por termos não apenas localizado esse arquivo, mas também por tê-lo transcrito e anotado em primeira mão. Dialogamos com Bruna Bianco, nesse processo, apontando a importância do pensamento do poeta que estava contido na linguagem livre, lúdica e apaixonada das cartas de amor dedicadas a ela.

No que diz respeito ao caráter voyeurístico da obra, é claro que, ao adentrarmos a intimidade epistolar de quaisquer dois sujeitos - e ainda mais aquela de um dos maiores poetas do século XX - podemos cair na tentação e na acusação de voyeurismo. Esquecese, no entanto, que o voyeurismo é complementar ao desejo exibicionista. O desejo de descobrir um segredo encerrado na íntima comunicação encaixa-se no desejo de revelá-lo ao mundo. Guardá-lo zelozamente por meio século até encontrar uma escuta para se contar uma história. No fundo, a decisão tomada por Bruna confirmou essa suposição. Em quantos substratos podemos ler Derrida em La carte postale, quando ele diz: "Quem escreve? A quem? E para mandar, destinar, expedir o quê? A que endereço?”416

Já agora retornando às epístolas, gostaríamos de destacar alguns momentos em que o processo de preparação do livro é revelado, já em sua reta final. No início, acompanhamos o nascimento do livro, as traduções transformadas em poemas, as réplicas corrigidas ostensiva e minuciosamente, até que, finalmente, em meados de 1967, o dialogo começa a ganhar outro corpo. Na Carta n. ${ }^{\circ}$ 202, datada de dia 31 de agosto de 1967, o poeta escreve: "Piccolina, Te mandei ontem o projeto da coletânea dos nossos poemas, aos quais deverão ser agregadas algumas nossas prosas, já que o livro não deverá ser volumoso". Segue-se, então, de agosto a dezembro, uma sucessão de informações sobre o andamento da

\footnotetext{
415 SANAVIO, Piero. "Una corrispondenza: Dialogo Ungaretti- Bianco"Revista Malacoda. https://malacoda4.webnode.it/una-corrispondenza-dialogo-ungaretti-bianco/ [consultado 14/04/2019]

416 DIAZ, Brigitte. Gênero epistolar O pensamento nômade. São Paulo: Editora EDUSP, 2016, p. 141.
} 
publicação, das quais recortamos aqui alguns trechos para ressaltar o envolvimento e o cuidado com esta edição:

Já pelos poemas, os Teus e os meus, o livro me parece de extraordinária beleza. Será uma tiragem de pouquíssimos exemplares de luxo, cada um terá uma ou duas combustões, de Burri que é, mortos Braque e Fautrier, o maior pintor do mundo depois de Picasso. ${ }^{417}$

Bem o nosso livro está sendo trabalhado. Será um grande livro: nele trabalharão Burri, o rei, o maior inventor da pintura de hoje, Romero, ${ }^{418}$ o artista gráfico mais competente, Leone, que dirige tudo, com seu afeto fraterno e filial. Deixei tudo nas mãos de Leone. Nas mãos mais confiáveis, de filho, de amigo, de discípulo. Seremos bem servidos, Piccolina. ${ }^{419}$

O livro "Dialogo" está no prelo, Burri fez uma combustão maravilhosa, para torná-lo ainda mais raro. 420

Minha bela, o nosso dialogo será um portento. Haverá 50 cópias com a combustão de Burri, e 50 sem combustão, 25 já foram vendidas (350.000 liras cada uma) para pagar o custo de impressão). Burri me presenteou com as combustões, e eu, no que diz respeito aos volumes que são nossos, dividirei em partes iguais entre Ti, Burri, eu e Leone. Só as cópias de luxo destinadas a cada um de nós, representam, para cada um, se as quisesse ceder, quase dois milhões de liras, e depois há as outras cópias que têm também um valor. Não é mal para "uma" poeta, (querida! brava!) que entra em campo de batalha pela primeira vez. Na minha época um ganho como esse, precisava de séculos de fama. Mas é verdade, não o digo para te adular, Piccolina, que Teus poemas são belos, entre os melhores que se fazem hoje. 421

Nos mesmos anos em que se corresponde com Bruna Bianco, Ungaretti prepara o volume Morte delle Stagioni, ${ }^{422}$ editado por Fógola, com o artista Giacomo Manzù. A obra inclui poemas de La Terra Promessa, Il Taccuino del Vecchio e Apocalissi, agregando finalmente o poema então inédito "Proverbi". Toda essa produção poética de Ungaretti incluída no volume é posterior a 1950. A edição, como sempre, é curada por Leone Piccioni, que assina a introdução, enquanto as notas e o aparato de variantes é um trabalho conjunto com Mario Diacono. O artista é quase sempre citado no intuito de dar à amada um panorama sobre o andamento do projeto. Mais uma vez, é possível observar o funcionamento do

\footnotetext{
417 Carta n. ${ }^{\circ}$ 202, datada de 31 de agosto de 1967.

418 Renzo Romero (1921-1994), fundador, com a esposa Flavia Tesio (1932-) da Litografica Romero, em Roma.

${ }^{419}$ Carta n. $^{\circ} 225$, datada de 30 de setembro de 1967.

${ }^{420}$ Carta n. $^{\circ} 232$, datada de 7 de dezembro de 1967.

${ }_{421}$ Carta n. $^{\circ} 244$, datada de 27 de dezembro de 1967.

422 La Terra Promessa foi publicado pela primeira vez em 1950 (Milão: Mondadori) e depois com acréscimos em 1954); a primeira edição de Il Taccuino del Vecchio é de 1960 (Milão: Mondadori); os coros reunidos sob o título Apocalissi (I-IV) fazem parte do volume Apocalissi e sedici traduzৃoni, com duas obras originais de Lucio Fontana (Ancona: Bucciarelli, 1965); o poema "Proverbi" aparece pela primeira vez nessa edição. Todos os poemas podem ser consultados em UNGARETTI, Giuseppe. Vita d'un Uomo. Tutte le poesie. A cura di Leone Piccioni. Milão: Mondadori, 2001 (coleção "i Meridiani".
} 
que denominamos como uma escuta privilegiada, sendo essa uma das funções que parece ocupar Bruna como receptora, não apenas dos poemas e do amor de Ungaretti, mas também das informações sobre o andamento de trabalhos, delocamentos e processo de escrita: "Vou escrever ao Marco para lhe perguntar se estará em Turim. Farei em Turim uma edição de luxo da Terra Promessa e doTaccuino com desenhos de Manzù, e em Turim preciso ir por este motivo. Receberás, assim que sair, a edição de luxo". ${ }^{423}$

É um período fértil para Ungaretti, pois, além da organização de sua obra completa, há publicações especiais. E Bruna faz parte desta construção. Em julho de 1967, o poeta cita numa única carta, em poucos parágrafos, os três projetos então em andamento: os livros com Manzù, com Burri e com Dorazio:

Em setembro deveria sair o volume torinês com as gravuras e traços de Manzù. Uma cópia sera para Ti. Espero que eu possa recebê-la antes da minhap artida para o Brasil e possa levá-la a ti. São no total 30 cópias. Manzù não vende nunca por menos de 150,000 liras cada uma de suas gravuras. Ainda não as vi. Leone diz que são belas. Será difícil que antes de fevereiro saia o volume que estão preparando os Suíços em San Gallo com Dorazio. É tudo em litografia, as pinturas, os meus textos. Será o livro mais lindo e mais fino. Depois deve haver o nosso livro, e de nós dois, com as gravuras de Burri. Temos boas notícias da sua saúde. ${ }^{424}$

Dorazio é o artista que casa sua arte com a de Ungà no projeto, tão único, de La Luce. Publicado em 1968, inclui uma seleção de vinte poemas escritos entre 1914-1961, manuscritos, e treze litografias originais, sendo cada uma das página solta, em brochura, coberta por um tecido verde e couro branco, com o nome dos autores em preto, publicado na Suíça, na cidade de São Galo, pela Erker-Presse. O belo poema dedicado a Bruna, "La tua Luce", ${ }^{425}$ contido no livro Dialogo, não faz parte da seleção — "Desaparece aos poucos, amor, o sol / agora que se aproxima a longa noite. // Com igual lentidão de suplício / Afastar-se eu vi a tua luz / Ainda numa não breve separação”. Entretanto, em todas as cartas a Bruna, o motivo da luz é recorrente, tanto quando evoca a sua amada como ao refletir sobre seus artistas prediletos - a luz como o amor, é um leitmotif. O livro La Luce, por sua vez, contém uma dedicatória à amada: "Para Bruna / a mais amada / minha luz temporal / a única que saiba / me encaminhar / ainda que com sumo / lamento de ter de / perdê-la / à eterna luz / Luz!" ${ }^{426}$ No ensaio "La luce del corpo: la memoria impossibile

${ }^{423}$ Carta n. ${ }^{\circ}$ 39, datada de Paris, 23 de outubro de 1966.

${ }_{424}$ Carta n. ${ }^{\circ} 173$, datada de Roma, 27 de julho de 1967.

425 LA TUA LUCE / / Scompare a poco a poco, amore, il sole / Ora che sopraggiunge lunga sera. // Con uguale lentezza dello strazio / Farsi lontana vidi la tua luce/ Pur un non breve nostro separarci. (in UNGARETTI, Giuseppe.

Vita d'un Uomo. Tutte le Poesie. Op. cit., p. 346.

426 "Per Bruna / la più amata / mia luce temporale / l'unica che sappia / avviarmi / sebbene con sommo / rimpianto di doverla / perdere/ all'eterna luce/ Luce!', consultada a obra do acervo de Bruna Bianco, Ungaretti, Giuseppe e 
dell'ultimo Ungaretti", Tommaso Tarani ${ }^{427}$ faz uma leitura detalhada de como o tema da luz perpassa a obra do poeta, não somente na palavra em si, mas em outras que funcionam como raios de refração da mesma. Segundo Tarani, os "vínculos do conceito de memória e de luz se aprofundam desde os primórdios da obra ungarettiana", evocando também um trecho do ensaio "Invenzione della poesia moderna", ${ }^{228}$ em que o poeta afirma que, "[...] da paisagem ao amor ressuscitado há uma distância, a memória, o infinito do homem". ${ }^{429}$ A questão enfrentada em 1941, quando Ungaretti ainda vivia no Brasil, mas poderia, de alguma forma, se encaixar também nas cartas trocadas com Bruna. O amor ressuscitado pelo encontro com a jovem e a redescobera da paisagem, temperados pela distância, provocada pela memória e pelo infinito. Para Tarani, há uma divergência entre os conceitos de luz e matéria, uma falta de relação — segundo o autor, uma irrelazione — no sentido de que a luz é sempre adotada como uma interrupção concedida ao nômade que carrega o peso da guerra ${ }^{430}$, uma intensa luminosidade que se contrapõe à treva do corpo. Antes de inscrever em sua poesia a memória objetivada como fenômeno, segundo Tarani, o poeta de Allegria relacionava à memoria um gesto de cintilância. E ele continua:

$[\ldots]$ giova anche ricordare che il tema memoriale nell' Allegria, ancora lontano dagli esiti sintetici raggiunti nel Sentimento del tempo (della memoria oggettivata in fenomeno) prende spunto nel primo lavoro poetico di Ungaretti unicamente dall'attimo luminoso (anche nelle sue varianti solare-stellare-lunare), quasi suggerito dalla pausa che avversa il travaglio bellico e pone, talvolta, il nomade in contatto col passato. ${ }^{431}$

Tarani tece sua teoria de luz e sombra para poder provar uma impossibilidade de memória no Ungaretti tardio, contrapondo-se, dessa forma, a Petrucciani, ${ }^{432}$ que em $I l$ condirionale di Didone, constrói, segundo Tarani, um contínuo contraste efêmero/eterno, travando, assim, uma luta antitética e não uma fusão entre a matéria revivida e a lembrança — circunstância em que haveria uma reciprocidade entre os pólos:

Analizzando infatti i due poli della sua funzione, l'autore [Petrucciani] scrive che il primo termine [l'effimero] non viene umiliato ma -al contrario - esaltato nel secondo [l'eterno], che a sua volta viene rivitalizzato dal primo, poiché nulla di ciò che diciamo esistenza può andare perduto: "ciò che è stato è stato per sempre" [...] Il tempo trascorso, l'effimero,

\footnotetext{
Dorazio, Piero. La Luce. Sangallo: Erker-Presse, 1968. Também consta em Vita d'un uomo. Tutte le Poesie. Comentário ao livro Dialogo. Op. cit., p. 1135.

427 TARANI, Tommaso. La luce del corpo: la memoria impossibile dell'ultimo Ungaretti. Chroniques italiennes web, 12 (04/2007).

428 UNGARETTI, Giuseppe. Invenzione della Poesia Moderna: Lezioni Brasiliane di Letteratura (1937-1942).

Napoli, Edizioni Scientifiche Italiane, 1984.

429 Ibid.

430 TARANI, Tommaso. Op. cit.

431 Ibid., p. 2.

432 PETRUCCIANI, Mario. Il condizionale di Didone. Napoli: Edizioni scientifiche italiane, 1985.
} 
contribuirebbe secondo Petrucciani al riempimento del serbatoio della memoria che, manifestandosi nell'istanza immateriale (da cui il suo valore fondante, luminoso) emaciperebbe dal caduco. ${ }^{433}$

O que falta, segundo Tarani, é não discutir a realidade da recuperação da memória, perguntar-se se, “[...] para ser honesta, a memória, deve assumir um corpo, vestir uma forma?” (p. 7). Todavia, enquanto o autor justifica que o símbolo da luz no último Ungaretti casa sempre com a esfera semântica do corruptível e fenomênico - e não do incorruptível e eterno, como sustenta Petrucciani - pareceu-nos, ao transcrever e traduzir as cartas a Bruna, que estes dois aspectos convivem na relação epistolar. Se há, por um lado, o sentimento trágico da finitude, relembrado toda vez em que o poeta se diz demente d'amore, por outro lado, há a renovação da esperança que ocorre através do encontro, da escuta representada pela amada. Entretanto, vejamos alguns recortes das cartas para aproximálos do pensamento de Dorazio sobre pintura, luz, cores e memória, na tentativa, assim, de avançarmos um pouco mais tanto em nossa proposta de leitura como de aprofundarmos as questões centrais do pensamento de Giuseppe Ungaretti:

Sou de memória, lucidíssimo. E já não sonho que lembro de ti, não estás distante, e apoiando-te em meu ombro, segues o que escrevo, e não preciso sonhar-te, Te vejo, Te aperto nos braços, Te digo que te amo. E mesmo o desejo. Te envio algumas fotografias - vejas me repito é imperdoável que me esqueça de já tê-lo dito poucos momentos atrás — com Fautrier e Paulhan. ${ }^{434}$

Falo sempre com Leone sobre o nosso amor, só com ele eu falo. Digolhe — eu o trato com o Tu e ele me trata como Sr. —: "Olha, não devo parar? Não te parece que eu abuse da confiança? Sinto remorso. Este meu amor, no final dos meus dias, não pode provocar outra coisa que não seja amargura". "É belissímo — me responde ele; e, digo eu a mim mesmo, será reamente verdade que é belíssimo? - é belíssimo este seu apego, e o apego da garota pelo Sr. É uma das coisas mais comoventes, veradeiras e admiráveis que podem florescer na terra. Não pare, não deve parar. Permanecerá como a sua poesia mais inspirada na memória, permanecerá na memória como um ato sublime como raramente ocorre, dos que podem ser contados nos dedos da mão. Não cometa o delito de parar, seria uma afronta gravíssima à sua poesia". ${ }^{435}$

Se voltarmos à pergunta de Tarani — "para ser honesta, a memória, deve assumir um corpo, vestir uma forma?” — vemos Bruna ora como presença encarnada para o poeta — “não preciso sonhar-te, Te vejo, Te aperto nos braços" — ora como extensão de sua poesia: "Não cometa o delito de parar, seria uma afronta gravíssima à sua poesia". Bruna é

433 TARANI, Tommaso. "La luce del corpo: la memoria impossibile dell'ultimo Ungaretti". Chroniques italiennes web, $12(04 / 2007)$, p. 5.

${ }^{434}$ Carta n. ${ }^{\circ} 186$, datada de Roma, 10 de agosto de 1967.

435 Carta n. ${ }^{\circ} 198$, datada de Roma, 26 de agosto de 1967. 
memória recente e presença ausente, ou ausência presentificada. Quando Ungà transcreve, recria, ou inventa as palavras que atribui ao seu fiel discípulo e amigo, Leone Piccioni, o que deseja justificar a continuidade deste amor, que por um lado provoca remorso, é a certeza de que algo dele permanecerá na memória, mas também afirma que a própria substância desse amor é algo que provém e é inspirado pela memória, como diz Piccioni: "como ato sublime [...] como sua poesia". Há uma ambivalência chiaroscura nas palavras com que o poeta tenta aferir a memória. É luminosa, Bruna é a sua luce, mas é também escura, há o remorso que obscurece o presente, algo já presente na poesia juvenil, como em "Godimento" (2017), "Sinto a febre / desta /luz plena// Acolho este / dia como/ fruta que se

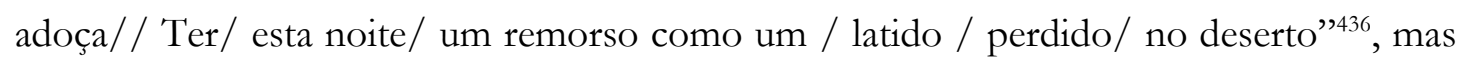
também num poema tardio, cujo título é "Rimorso", editado após sua morte: "La mia vita / è già / così colma / di morte [...] Vorrei essere / piccolo e ignaro/ avere /i sensi vergini/ godere/ senza'apprensione/ di quest'abisso/ che mi cresce/ ne cuore" ${ }^{\prime 37}$ — a presente dialética entre memória e inocência, luz e sombra.

Ao pensar sobre a memória em Ungaretti, Tarani afirma:

$[\ldots]$ vedremo come sia la memoria stessa ad assumere inaspettati esiti di tenebra qualora non risulti suggellata dall'evidenza innocente e inoppugnabile della realtà. Da qui la definizione di memoria impossibile, essendo questa sempre vincolata all'evidenza fisica dell'assente e mai all'arbitrarietà del pensiero (o memoria negativa) pensiero costituirebbe, in quest'ottica, non salvezza ma dannazione. ${ }^{438}$

A interpretação de Tarani poderia se encaixar nesse jogo de presença e ausência entre o poeta e sua amada, porém, no fundo, a treva é sempre temperada pela invocação da luz, nem toda memoria é escuridão - o poeta até conjuga, nas cartas a Bruna, os anos de grande dificuldade econômica vividos nos arredores de Roma, anos duros, mas dos mais fecundos para sua poesia. Assim, poderíamos seguir também o pensmento de Petrucciani, já que, em boa parte do diálogo, há a esperança do reencontro entre dois amantes. No poema "Di persona morta divenutami cara sentendone parlare", ${ }^{439}$ do livro La Terra Promessa, lemos:

$$
\begin{aligned}
& {[\ldots]} \\
& \text { Ma, carezzevole, la tua parola } \\
& \text { Rivivere già fa, } \\
& \text { Più a fondo, } \\
& \text { Il brevemente dolore assopito } \\
& \text { Di chi t'amò e perdutamente } \\
& \text { A solo amarti nel ricordo } \\
& \text { È ora punito. }
\end{aligned}
$$

\footnotetext{
436 UNGARETTTI, Giuseppe, tradução nossa. In CRICELLI, Francesca. Repátria. Op. cit., p. 109

437 UNGARETTT, Giuseppe. Vita d'um uomo. Tutte le poesie. Op. cit., p. 468.

438 TARANI, Tommaso. "La luce del corpo: la memoria impossibile dell'ultimo Ungaretti". Chroniques italiennes web, 12 (04/2007), p. 7.

439 UNGARETTI, Giuseppe. Vita d'um uomo. Tutte le poesie. Op. cit., p. 283.
} 
Dirige-se à pessoa morta, descrevendo a dor de quem fica, descreve a possibilidade de amar somente na lembrança como uma forma de punição — diretamente em diálogo com "Il Dolore", como se o poeta falasse em seus versos também ao filho Antonietto: há uma convergência entre os temas, um mútuo reconhecimendo da perda e do luto. Em contraste, podem ser contrapostas a estes versos as linhas dirigidas a Bruna, onde a lembrança é menos sombria e serve como ancoragem:

Não, não quero ser um pregador. Mas dizer-te que te amo, e como poderia me saciar em dizê-lo? É uma impaciência, uma ansiedade, um tremor, um escancarar improvisamente os olhos felizes, e depois fechá-los com pena pois a Tua presença é por agora somente aquela do sentimento, da fantasia, da memória, da esperança obstinada. ${ }^{440}$

Parece que nos distanciamos um tanto da relação de Ungaretti com Dorazio, porém, no fundo, o caminho foi necessário para aproximar uma leitura comum entre os dois colaboradores e amigos, ora explorada na pintura, ora na poesia. Dorazio, sobre sua arte, afirmou: "L'arte della pittura non è destinata alla fabbricazione più o meno ingegnosa di immagini, ma alla ricerca di quegli elementi chiave della percezione visiva che generano il modo di vedere e di intendere le immagini” ${ }^{\prime 41}$ — a arte da pintura não é destinada à fabricação engenhosa de imagens, mas à procura dos elementos-chave da percep̧̧ão visual que geram $\mathrm{O}$ modo de ver e compreender as imagens. A chave é a perceção, essa busca por algo que facilite e proponha um acesso, não só um esforço mimético. A obra assinada por ambos, La luce, parece compartilhar esse esforço e, na combinação deste encontro, Bruna está, de alguma forma, presente:

Esta carta foi interrompida porque D’Orazio veio me buscar em casa para me mostrar as folhas que indicam como está indo nossa edição da

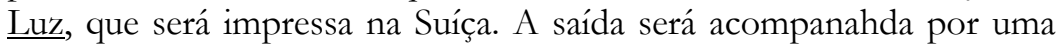
festa campestre, num velho castelo, e deverías estar com o velho Unga para dar-lhe tua luz. Minha luz, querida luz, luz única, te amo. ${ }^{442}$

Memória e a inocência, luz e escuridão, elementos que servem como balizas para o pensamento e a poesia de Ungaretti, seus elementos-chave para a percepção, elementos que geram um modo de ver e compreender o mundo, de compreender a si mesmo. Relembramos um trecho, já visitado, em que ele fala do espelho fosco que encontra, observação que o faz voltar a Mallarmé, mas também à memória: “aqui diante há um espelho embaçado com algumas rachaduras no antigo prateado. É como a minha memória, e entendo porque

\footnotetext{
${ }_{440}$ Carta n. ${ }^{\circ}$ 200, datada de Roma, 28 de agosto de 1967.

441 DORAZIO, Piero. Cui prodest, 1967 (http://archiviopierodorazio.it, consultado em 20 de dezembro de 2018).

${ }^{442}$ Carta n. ${ }^{\circ}$ 117, datada de Roma, 14 de fevereiro 1967.
} 
Mallarmé amasse tanto estes espelhos". ${ }^{443}$ A memória como algo que nunca se recupera plenamente, mas também se reconstrói a partir de uma imagem embaçada. A observação de Ungà nos lembra também como a pesquisadora Brigitte Diaz começa a desenvolver seu pensamento a respeito das missivas como escrita de si, quando escreve:

[...] por mais que a carta seja tradicionalmente considerada um espelho da alma, é um espelho que deve, na maioria das vezes, ficar sem brilho. Pode apenas refletir a imagem idealizada daquele ou daquela a quem se dirige a carta: espelho do outro, portanto, mais que de si. ${ }^{444}$

E, no equílibrio tênue entre as duas margens, podemos enfim tensionar o que que foi proposto acima, forçando uma síntese provisória entre o aspecto corruptível e fenomênico e incorruptível e eterno da dualidade "luz e sombra", "memória e inocência", tão presentes em Ungaretti. Para o poeta, "custa caro ter um coração sempre jovem, um coração sempre ingênuo, sempre inocente”, e ele diz: "custou-me anos de inferno". 445 Há cartas em que Ungà assina como Piccolino ("pequenino"), e refere-se a Bruna como Piccolina, dizendo: "não sou se não um piccolino, mesmo tendo tantos anos, e tantas terríveis lembranças. Mas se Te olho e Te vejo sempre, mesmo de longe, até as lembranças terríveis não me ferem mais, e me dizem, aquelas duras lembranças, me dizem, e é amargo ouvi-lo, que me formaram o coração que tenho, de perene piccolino" (carta datada de 27 de dezembro de 1967). A construção da inocência, com o passar dos anos, é um trabalho árduo, uma travessia dantesca — "custou-me anos de inferno" — a possibilidade de maravilhar-se e encantar-se diante da existência, sentir-se atravessado pela vida e que isso provoque um verso, uma observação. Desta forma, Ungaretti segue inspirado pela troca que tece com Bruna e também com seu irmão Marco — o poema "Soliloquio", entre os novos poemas da obra completa, foi escrito com a intenção de ser musicado pelo irmão de sua amada.

No mesmo período em que escreve seu texto sobre Vermeer, Ungaretti também escreve a apresentação do catálogo de uma importante exposição do artista plástico Corrado Cagli. Embora o texto não esteja incluído no volume de ensaios de Vita d'un uomo, o artista aparece diversas vezes nas cartas a Bruna. Prevalecem relatos sobre o andamento da escrita do texto para o catálogo, mas há também encontros e exposições, assim como um quadro que o poeta recebe como presente por sua apresentação, que ele ato contínuo doa à sua amada. Há respotas em que relata que o quadro estaria em exibição em alguma exposição, porém, sem ter acesso às cartas escritas por Bruna, não podemos inferir se o poeta

${ }^{443}$ Carta n. $^{\circ} 89$, datada de 14 de janeiro de 1967.

${ }^{444}$ DIAZ, Brigitte. Gênero epistolar O pensamento nômade. São Paulo: Editora EDUSP, 2016, p. 141.

445 Carta datada de 27 de dezembro de 1967. 
respondia a cobranças ou simplesmente discorria sobre o desenrolar dos fatos. Um dado aparentemente menor, periférico, que surge inúmeras vezes quando escreve sobre Cagli. é um pequeno relógio que deseja adquirir para presentear sua amada e a mãe dela. O pequeno relógio parece uma jóia. A busca obsessiva envolve Cagli, pois aparentemente só uma antiquário na Sicília possui o objeto que o poeta deseja. Cagli se torna o intermediário para chegar até ele. Nos últimos meses do relacionamento com Bruna, o poeta do sentimento do tempo deseja ofertar um objeto-símbolo, um amuleto, que parece carregar tanto valor material como imaterial. Quão mensurável e efêmero seria o tempo entre os dois amantes? Qual o tempo em que ocorre, de fato, o encontro entre ambos? Como possibilidade de leitura, destacamaos aqui alguns trechos para ressaltar tanto a busca pelo quadro, como a pelo relógio e. enfim, algum aspecto mais claro do distanciamento entre Bruna e Ungà:

Cagli me deu um quadro, após meu prefácio ao seu catálogo. Gostaria de oferecê-lo a ti. A casa de Ninon está cheia de quadros, alguns de grandíssimo valor comercial, e também artístico, que aos poucos lhe doei. Posso, com toda tranquilidade de consciência, oferecer algo à pessoa que mais amo no mundo, que conforta os meus últimos dias, que me permite continuar a viver. Será a única que se lembrará de mim, como de uma pessoa realmente perdida, quando Deus terá me chamado. ${ }^{446}$

No que diz respeito ao quadro de Cagli, anda pelas exposições, e Cagli ainda não se decide a entregá-lo a mim. Coloca nas monografias e catálogos, propriedade de Ungaretti, mas por enquanto faz como se fosse propriedade sua. Segura-o pois lhe parece bom aquele "propriedade de Ungaretti". De todo modo, espero tê-lo em breve.447

Hoje estive com Cagli no almoço. O quadro me me permito oferecerte será exposto, ainda uma vez, pela Rizzoli, aqui em Roma e deposi em Milão, e de cada dos dez quadros que serão expostos, que são aqueles descritos por mim no prefácio, o primeiroentre todos é o teu (...). Não poderei levar-te o quadro. O receberás chegando na Itália, e iremos juntos cumprimentar Cagli. Verás seu lindo ateliê, tem móveis e objetos escolhidos e dispostos com um gosto muito refinado. É um pintor eclético, mas um grande pintor. ${ }^{448}$

Entre os três trechos apresentados acima e os três que seguem, há um hiato que compreende a viagem de Bruna à Itália para os festejos de oitenta anos de Ungaretti, período em que viajaram juntos a diversos lugares na Itália e na Europa, sua estadia com Cagli na Sićlia e a outra viagem de Ungaretti ao Brasil, quando retorna para visitar sua amada e receber o título de doutor honoris causa concedido pela Universidade de São Paulo. Há um período de mais ou menos um ano e meio entre a preocupação com o texto de apresentação do

\footnotetext{
446 Carta n. ${ }^{\circ}$ 181, datada em Roma, 4 de agosto 1967.

${ }_{447}$ Carta n. ${ }^{\circ} 198$, datada de 26 de agosto de 1967.

448 Carta n. $^{\circ} 220$, datada de 22 de setembro de 1967.
} 
catálogo do amigo pintor e a busca pelo objeto raro, aquele amuleto do tempo. Algo começa a mudar entre os dois, ruir, talvez. Em várias cartas, Ungaretti reclama do tom com que Bruna se dirige a ele. Seguem-se algumas tentativas de certificar alguma garantia, monetária, ou de herança, sobre seus livros que já havia dito que deixaria à amada. Vale lembrar que essa preoupação surge anteriormente, quando escreve à margem da página, em julho de 1968: "[...] gostaria que as coisas do meu quarto fossem Tuas: o Fautrier, o Burri, as gravuras raras de Rembrandt; mas será possível? Terás um cheque mensal, também, é natural." Seguem os outros três trechos mencionados:

Cagli me diz descontente de ter recebido uma Tua carta estranha. O que lhe escreveste? Lia e relia as Tuas cartas. Não entendia. Não entendo. Não mudei, tenho a mesma esperança; mas me diceste que daqui seis meses virias à Itália, dizia-mo com tom maldoso, e que terías reclamado os livros prometidos. Depois diceste que não voltarías nunca mais. São os livros do meu trabalho. Imediatamente, se devo continuar a trabalhar, não será possível dá-los a ti. Mas não quer dizer que não manterei minha promessa, talvez com uma cláusula específica de testamento. De toda forma, mesmo se nossas relações tivessem de se romper, a cláusula permanecerá. Penso muito nisso, será nestes dias. É amargo ter de te escrever neste tom. Te amo de um jeito que não pode ser equiparado a nenhum outro. Te amo com uma fúria que me martiriza porque não sei se é razoável, e se te agrada que ainda esteja apaixonado por Ti, minha musa, minha luz. ${ }^{449}$

Pedi também para Cagli, o relógio, e está se ocupando disto através de um amigo relojeiro. Suspenso em todo caso, com a condição de anular a aquisição aqui se Cagli, quando terei voltado para Roma (dia 4) tivesse já encontrado ele mesmo o pequeno objeto. 450

Encontrei o relógio, tem mais de cem anos e é pontualíssimo. Caminha como a bela o seguia em seu tempo, há mais de um século. Este é para Tua mãe. Para Ti há o que encontrou Cagli e já está com ele. Ti amo B.451

Há uma rica trama de relações entre os temas tocados por Ungaretti em sua poesia e aqueles enfrentados por tantos artistas plásticos que orbitaram em sua vida, seja como pesquisa e escrita, quanto como relação pessoal cuidadosamente articulada no decorrer dos anos. Tentamos propor aqui um caminho entre tantas referências. Outros aspectos podem ser encontrados e não estão só circunscritos aos artistas mencionados e às obras citadas: é uma urdidura rica com inúmeros nós, assim como os mais preciosos tapetes de seda do Oriente. Podemos colher esses aspectos também no cinema, quando Ungaretti fala de Pasolini, ou quando se desdobra longamente sobre a figura de Salomé e enlaça o texto bíblico à obsessão literária presente ao longo do tempo em tantos autores e pintores. Seria impossível

${ }^{449}$ Carta n. $^{\circ}$ 352, datada de 6 de janeiro de 1969.

${ }^{450}$ Carta n. ${ }^{\circ} 361$, datada de 25 de janeiro de 1969.

451 Carta n. $^{\circ} 362$, datada de 28 de janeiro de 1969. 
tentar encerrar nesta discussão todos os temas discutidos pelo autor ao longo de sua vida e de sua obra. Porém, o que tentamos propor é justamente uma cartografia de leitura. Escolhemos um caminho de leitura dentro deste acervo de cartas para ressaltar algumas das preocupações recorrentes de Giuseppe Ungaretti — traçar um paralelo entre a confissão presente nas cartas, em ritmo de diário íntimo, e a organização de sua obra completa, Vita d'un nomo, em seus diversos volumes.

\subsection{ARTES, ARTISTAS E INTELECTUAIS NO BRASIL DE UNGÀ}

Talvez um dos melhores retratos sobre os anos de Ungaretti no Brasil — sua vivência em São Paulo entre os anos de 1937 e - seja aquele do escrito pelo professor Antonio Candido. ${ }^{452}$ A força com que descreve sua partida é digna de um verso ungarettiano: "quando voltou à Itália foi como se tivessem arrancado alguma coisa da cidade, que ele marcou profundamente em muitos setores, embora sem rumor" ${ }^{\prime \prime 53}$ - e para usar uma imagem contrária, mas em diálogo, com este ser arrancado de um lugar, recordamos que Ungà é também o poeta de innumerevoli innesti, foi enxertando seus afetos no Brasil com sua própria existência, com sua forma de olhar para o mundo. Assim como Candido descreve seus mais fiéis amigos e seguidores na cidade de São Paulo como uma espécie de maçonaria ungarettiana, também existem, numerosos, estudiosos de sua obra e vida que, há quase meio século da morte do poeta, se interessam por algo que pode, talvez, ainda ser revelado a partir da descoberta de um arquivo. Cândido afirma: "há mesmo uma espécie de maçonaria entre eles", e continua: “alimentada por alusões a experiências comuns, evocações de fatos pitorescos ou comoventes que [...] os lançou, como um ciclo de Ungaretti, na mitologia artística e intelectual da cidade". ${ }^{454} \mathrm{Se}$, por um lado, Ungaretti carregou para sempre a sua experiência brasileira, com a imensa dor da perda do filho, considerando o nosso país a sua quarta pátria, a sua "pátria humana", por outro, aqui deixou o seu legado.

Segundo Augusto Massi, ${ }^{455}$ o primeiro grupo de amigos foi constituído pelos alunos e fundadores da revista Clima: Lourival Gomes Machado, Ruy Coelho, Antonio Candido, Décio de Almeida Prado e Paulo Emílio Sales Gomes. Entre esses, aparecem nas cartas Lourival

\footnotetext{
452 CANDIDO, Antonio. Ungaretti em São Paulo. Estud. av. Vol. 8. N. 22. São Paulo, Sept./Dec. 1994 (http://www.scielo.br/pdf/ea/v8n22/25.pdf, consultado em 12 de agosto de 2015).

453 Ibid.

454 Ibid.

455 MASSI, Augusto. As passagens brasileiras. Folha de São Paulo, 21 de julho de 1996 (https://www1.folha.uol.com.br/fsp/1996/7/21/mais!/6.html, consultado em 12 de agosto de 2015.
} 
Machado, ${ }^{456}$ Candido $^{457}$ e Paulo Emílio, ${ }^{458}$ mas também são citados João Guimarães Rosa, ${ }^{459}$ Edoardo Bizzarri, ${ }^{460}$ o então diretor do Instituto Italiano de Cultura e tradutor de Guimarães Rosa, Eunice Catunda, ${ }^{461}$ Chico Buarque de Hollanda ${ }^{462}$ e Vinícius de Moraes, ${ }^{463}$ além de Aleijadinho ${ }^{464}$ — cujas obras Ungaretti seu sonho de conhecer de perto em 1966, acompanhado por Bruna e Celso Frederico, irmão da ensaísta Ecléa Bosi e de Alfredo Bosi ${ }^{465}$ — Di Cavalcanti, ${ }^{466}$ Lygia Fagundes Telles, ${ }^{467}$ Waldeloir Rego, ${ }^{468}$ Jorge Amado, ${ }^{469}$ Mário de Andrade, ${ }^{470}$ Oswald de Andrade, ${ }^{471}$ Carlos Chagas Filho e até Castelo Branco.

Entre tantos citados, porém, merece especial destaque o poeta Murilo Mendes, citado em uma única carta - a Carta n. ${ }^{\circ} 356^{472}$ — na qual o poeta nascido em Alexandria inclui a transcrição do poema que o mineiro lhe dedicou, pronta para publicação na revista L'Approdo. Um poema retrato de Ungà, que poderia, em alguma medida, até espelhar seu próprio poema "Manhã", como observaremos mais adiante:

\section{UNGARETTI}

Il viaggiatore non ancora stanco

di aver girato il mondo con le sue varianti

fantasticando sulle galassie

(lontanissime oppure centro dell'uomo?

that is the question)

portando gli emblemi della memoria

gli occhi alessandrini

sotto il colbacco nero

dopo aver guardato ammirato urlato ovunque

si ferma tutta la notte

e il giorno successivo

sulla dinamica delle parole

456 Cartas n. ${ }^{\circ} 115$ e 137.

${ }_{457}$ Cartas n. $^{\circ}$ 62, 285 e 290.

${ }^{458}$ Cartas n. ${ }^{\circ} 1.168,185,206,330$ e 331.

${ }^{459}$ Cartas n. ${ }^{\circ} 161$ e 285.

${ }^{460}$ Carta n. $^{\circ} 117$.

461 Cartas n. $^{\circ} 5$ e 290

${ }^{462}$ Cartas n. $^{\circ} 353,354,358,365,370,371,372,375$ e 376

463 Vinícius surge em muitas cartas, pois Ungaretti compartilha o trabalho de tradução de poemas seus com Bruna (Cartas n. $^{\circ} 305,449,350,351,352,353,354,355,358,364,364,365,366,367,368,369$, 370, 371, 372, 275 e 376). ${ }^{464}$ Cartas n. $^{\circ}$ 62, 115 e 137.

465 MASSI, Augusto. As passagens brasileiras. Folha de São Paulo, 21 de julho de 1996 (https://www1.fo-

lha.uol.com.br/fsp/1996/7/21/mais!/6.html, consultado em 12 de agosto de 2015), complementatado pela entrevista de Antonio Candido à professora Lucia Wataghin em junho de 1995 (Tratto dalla rivista Poesia Sempre, Biblioteca Nacional, Rio de Janeiro, Giugno 1995, traduzione di Julio Monteiro Martins) e reproduzida em italiano no endereço http://www.sagarana.net/rivista/numero9/saggio1.html (consultado em 12 de agosto de 2015).

${ }^{466} \mathrm{Cartan}^{\circ}{ }^{\circ} 301$.

${ }_{467}$ Cartas n. $^{\circ} 168,185,330$ e 331.

468 Cartas n. $^{\circ} 184$ e 228.

${ }^{469}$ Cartas n. $^{\circ} 228$ e 285

${ }^{470}$ Cartas n $^{\circ}{ }^{\circ} 9,10$ e 286.

${ }^{471}$ Cartas n. $^{\circ}$ 9, 10, 354 e 375.

472 Datada de 15 de janeiro de 1969. 
MALLARME'

GONGORA

WILLIAM BLAKE

MEMORLA

CRISI

CATASTROFE.

Esisterà domani

la parola domani?

Não há outra menção ao poeta, somente o datiloscrito do poema numa folha com cabeçalho "Rai - Radiotelevisione italiana Sede di Firenze - L'Approdo n. 1075", e a data 30/12/1968 - escrita à mão por Ungaretti.

Juntando alguns fios soltos de uma tessitura que seguimos até aqui, em nossa proposta de uma cartografia para a leitura desse acervo, Ungaretti se apresenta à amada com os versos e o olhar de um dos nossos grandes poetas. Ungaretti prefaciou Siciliana e foi seu tradutor em Finestra del caos. ${ }^{473}$ Em seu texto, Ungaretti observa na poesia de Murilo aquilo que em certa medida está em diálogo com sua própria obra e visão de mundo, um movimento bastante característico da crítica do poeta nascido no Egito, que diz: "com encantadora surpresa, Murilo Mendes descobre em si aquela hora antiga da história humana em que intelecto, sentimento e sentidos encontraram seu equilíbrio puro, objetivo". ${ }^{474} \mathrm{O}$ poeta mineiro chegaria a tal equilíbrio "atravessando seu mundo barroco $[. .$.$] com a angústia que$ o dilacera, como dilacera todos os contemporâneos." ${ }^{475}$

No poema-retrato, Murilo Mendes nos apresenta "Um viajante não cansado ainda / de girar o mundo com suas variantes", e nos diz do poeta que cruza o Atlântico para encontrar sua amada, mas também para lecionar em Harvard, conhecer o Japão, representar a Unesco - Ungaretti, com os seus quase quatro vezes vinte anos, é um poeta errante que carrega atentamente, em sua bagagem, as muitas variantes dos seus poemas. Ungaretti é o poeta de galáxias distantes que se espelham também por dentro, no âmago do homem, como vimos em suas observações sobre a obra de Fautrier; é o poeta de olhar alexandrino sob um gorro russo que — após viver, observar e gritar — se detém sobre o jogo de palavras-conceitos, esmiuçando suas obsessões e referências.

473 MENDES, Murilo. La finestra del caos. Tradução italiana de Giuseppe Ungaretti. Milão: All'insegna del pesce d'oro, 1961.

474 AMOROSO, Maria Betânia. Murilo Mendes o Poeta Brasileiro de Roma. São Paulo: Editora UNESP, 2013, p. 110.

475 Ibid. 
Mendes segue enumerando: "memória, crise e catástrofe" após citar: "Mallarmé, Góngora e William Blake"; mas amanhã, existirá, ainda, a palavra amanhã? Na urdidura dos temas e dos autores traduzidos, autores-referência, permanece o bordado da linguagem. Murilo Mendes e Giuseppe Ungaretti compartilham este gesto de se interrogar sempre sobre os destinos da linguagem, sobre as dimensões da língua; e, assim, o poeta que presta a homenagem também se inclui nos versos, como Velásquez aparece num pequeno detalhe, no quadro "As meninas" — uma forma de assinatura.

A meditação sobre a função da linguaguem poética não é a única que os autores compartilham: há também um pensamento que se debruça sobre a própria função do poeta. Nos aproximamos, aqui, do que Carlo Ossola ${ }^{476}$ observa como outro ponto de contato entre o poeta de Alexandria e o de Juiz de Fora. A função do poeta seria, entre outras coisas, a de dar um nome autêntico às coisas, nomear a história esvaziada de sentido. Para Murilo Mendes, “[...] a missão especial do poeta consiste em revelar o território da poesia, nomeando todas as coisas criadas e imaginadas, instalando-as no espaço da linguagem, dando a elas uma nova dimensão"; 477 já para Ungaretti, “[...] as coisas perdem a paciência, se preocupam para que o homem dê a elas o nome de cada uma, fale delas", pois "[...] mais tarde, e não muitos anos após Dante, saberemos que a natureza vazia havia sido preenchida pelo homem, humanizando-a, povoando com nomes, quase como tivesse criado ele mesmo o mundo". ${ }^{478}$ Nomear o mundo e fazê-lo existir a partir desta gênese poética é algo que se manifesta também na poesia desses autores. Murilo Marcondes de Moura cita o poema "Manhã" em "O desafio do poeta", ${ }^{479}$ um poema que, segundo o autor, só poderia ter sido escrito por Murilo Mendes na literatura brasileira, "não pela limpidez e pelo despojamento [...], mas sim pela altivez e positividade com que [...] é traçado o autorretrato de poeta e também pelo seu modo resoluto de exaltar os poderes da poesia ${ }^{480}$, .

$\mathrm{Na}$ análise de Moura do poema "Manhã", de Murilo Mendes, vemos como a experiência do mundo começa a ser plena e possível somente a partir do que é oferecido como vivência registrada em verso pelo poeta, como se a vivência do poeta fosse a baliza para sentir o mundo. Abre o poema assim: “As estátuas sem mim não pode mover os braços /

\footnotetext{
476 OSSOLA, Carlo. Ungaretti, poeta. Op. cit., p. 90, trechos traduzidos por nós e inseridos nesse fim de parágrafo. 477 Retrotadução nossa da fala de Murilo Mendes, a partir da citação de Carlo Ossola. A fala de Murilo Mendes pode ser encontrada em Murilo Mendes, a cura de R. Jacobbi, Milão: Nuova Accademia, 1961, pp.163-371.

478 UNGARETTI, Giuseppe. Commento al Canto Primo dell'Inferno. Vita d'um Uomo. Saggi e Interventi. Milão: Mondadori, 2001, p. 367, coleção “I Meridiani”" (p. 371 na edição consultada por Ossola).

479 MOURA, Murilo Marcondes de. O mundo sitiado: A poesia brasileira e a Segunda Guerra Mundial. São Paulo: Editora 34, 2016, pp. 285-290.

480 MOURA, Murilo Marcondes de. O mundo sitiado: A poesia brasileira e a Segunda Guerra Mundial. São Paulo: Editora 34, 2016, pp. 285
} 
Minhas antigas namoradas sem mim não poderão amar seus maridos", "Muitos versos sem mim não poderão existir" ${ }^{\text {481 }}$ — não são só os versos escritos mas também a experiência sentida e vivida a partir do verso, a partir da leitura do poema; por fim, Murilo Mendes diz ser poeta irrevogavelmente, "Mesmo explorado pelos outros homens", pois "É absurdo achar mais realidade na lei que nas estrelas". ${ }^{482}$ Segundo Moura, "o que soa apenas como bravata pede para ser lido [...] como profissão de fé [...] o verso quer afirmar que o poeta é um autêntico criador"; ${ }^{483}$ quando Mendes escreve "é difícil não amar a vida", parece aproximar-se das considerações finais de Ungaretti em seu ensaio "Ragioni d'una poesia". Segundo Ungà, "só a poesia [...] pode recuperar o homem", 484 aprendizado adquirido a duras penas, diz o poeta - este encontrar mais realidade nas estrelas do que na lei, versificado por Mendes, como para Ungaretti — "l'uomo è molto meno regolato dalla propria opera che non sia alla mercé dell'Elemento", ${ }^{485}$ o homem é muito menos guiado por sua obra quanto não esteja à mercê do Elemento. Poderíamos, então, juntar estrelas ao Elemento, mistério ao aspecto místico e religioso que rege a vida destes poetas para além das leis dos homens.

Se há um outro ponto em que se cruzam as poéticas de Ungaretti e Murilo Mendes, além da paixão cruzada Itália-Brasil, é onde constatamos a presença de uma manifestação de culturas em transição, mas também de uma busca pelo sentido do ofício e dos devaneios da língua, ou por compartilharem aquilo que Prisca Agustoni descreve ao falar do poeta mineiro: “[...] poéticas deslocadas do próprio ponto de origem, muitas vezes deslocadas da fonte primária de criação que é a língua materna". ${ }^{486}$ No caso de Ungaretti, como vimos anteriormente, o fato de haver nascido em Alexandria, se criado na francofonia e sido exposto à língua árabe, tendo também publicando poemas não apenas em italiano mas também em francês; no caso de Murilo Mendes, um poeta que se moveu, mais tardiamente, para o campo da criação noutra língua, adotando também a língua italiana como seu instrumento de criação poética. O poeta de Juiz de Fora afirmou-se como poeta nessa língua, obtendo reconhecimento por sua obra também na Itália, também conquistando, como Ungaretti, o prêmio Taormina. Ambos os poetas possuem "vozes poéticas que são, ao

\footnotetext{
481 Ibid.

482 Ibid.

483 Ibid.

${ }^{484}$ UNGARETTI, Giuseppe. Vita d'um Uomo. Tutta la poesia. Milão: Mondadori, 2001. p. 38, coleção "I Meridiani”. 485 Ibid.

486 AGUSTONI, Prisca. A presença da poesia italiana em Ipotesi, de Murilo Mendes. Remate de Males. 32.1, Jan./Jun. 2012. Campinas. p. 54.
} 
mesmo tempo, contaminadas pelo e agentes contaminantes do cânone literário estabelecido"487 para seguirmos o caminho apontado por Agustoni. Tomamos a observação da autora sobre Murilo Mendes com a intenção de expandí-la para incluir sob seu toldo também Ungaretti entre as vozes que são tanto contaminadas pelo quanto agentes contaminantes do cânone literário estabelecido. Ungaretti na Itália e Murilo Mendes no Brasil modificaram e ampliaram as categorias da poesia nacional. Se Mendes revindicou sua "cidadania poética" 488 na Itália, Ungaretti admitiu que sua pátria humana foi o Brasil. Há um lugar em que se inscreve a criação, para ambos, que é tanto abstrato, para seguir Agustoni, quanto concreto - temos em mente aqui a ampla vivência de Mendes na Itália e de Ungaretti no Brasil. Em alguma medida, são dimensões interpenetráveis, Brasil e Itálila, pátrias ampliadas para esses autores que, mantendo suas diferenças, escolheram preservar uma dimensão de invocação ao transcender a vida terrena em suas obras, um deslocamento que surge às vezes quase como aquele dos versos do pastor de Leopardi, que se dirige à lua: "ove tende / Questo vagar mio breve, / Il tuo corso immortale?” Mendes e Ungaretti trabalham num território que é também "um lugar poético [...] onde pudessem desembocar todos aqueles que estivessem vivendo em estado de errância, seja ela histórica, existencial ou linguística". ${ }^{489}$

Se dermos alguns passso atrás, para pensarmos a relação de Ungaretti e Mendes antes mesmo de aquele haver conhecido Bruna, conseguiremos iluminar alguns aspectos em que os dois poetas se aproximam, e isso abrirá caminho para pensar também esse espaço poético do entre. Giuseppe Ungaretti fez um breve retorno ao Brasil antes de encontrar Bruna, em 1954, conforme confirma Antonio Candido: “[...] após a guerra ele voltou em 1954, fui a Santos esperá-lo com Paulo Emílio. Fez então uma conferência extraordinária no Instituto de Cultura Ítalo-Brasileiro e leu, na faculdade, na rua Maria Antônia, suas traduções de Mário de Andrade". ${ }^{490}$ Entre 1954 e 1955, Murilo Mendes, entre suas viagens, passou por Roma, e seu período de permanência foi de 1957 a 1975, período em que foi leitor na Universidade La Sapienza, o que lhe permitiu fazer intensas viagens pelo país e quando também escreveu Siciliana, obra pubicada em 1959 numa edição bilíngue, ${ }^{491}$ prefaciada pelo próprio Ungaretti. A Sićlia é uma região que surge em muitas conversas com Bruna, pois

\footnotetext{
487 Itálico nosso para indicar o ênfase colocado pela autora usando aspas. AGUSTONI, Prisca. O diálogo hipotético de Murilo Mendes. Revista de Cultura Agulha. N. 45. Fortaleza/São Paulo. Maio 2005. http://www.jornaldepoesia.jor.br/ag45mendes.htm, consultado em 15 de janeiro de 2019.

${ }^{490}$ Entrevista de Antonio Candido à professora Lucia Wataghin em junho de 1995 (Tratto dalla rivista Poesia Sempre, Biblioteca Nacional, Rio de Janeiro, Giugno 1995, Traduzione di Julio Monteiro Martins) e reproduzida em italiano no endereço http://www.sagarana.net/rivista/numero9/saggio1.html (consultado em 12 de agosto de 2015, retrotradução nossa).

${ }^{491}$ MENDES, Murilo. Siciliana. Tradução italiana de A.A. Chiocchi. Caltanissetta (Sicília): Editore Salvatore Sciascia, 1959.
} 
o poeta deseja levar a sua amada para lá, assim como fala do desejo de visitar Minas e seguir o caminho das obras de Antônio Francisco Lisboa, o Aleijadinho — há algo comum deste topoi barroco siciliano, mas também brasileiro, que provoca tanto interesse em Ungaretti e também em Murilo Mendes. Numa carta datada de novembro, Ungaretti escreve:

Veremos Siracusa juntos, e tantas outras coisas de graça e de temor que preenchem a Sicília de signos desde sempre iningualáveis para a inspiração dos poetas. Em Siracusa há um rio que é como um mar morto, navega-se num barco infernal, e chega-se assim no meio dos campos na água dos papiros. São corredores estreitíssimos. ${ }^{492}$

A Sicilia exerce esse fascínio em Ungaretti, claro, e também em Murilo Mendes, mas historicamente em inúmeros outros poetas, como recorda Horácio Costa: "[...] a ilha triangular, a Trinácria dos gregos antigos [...] um destino fabuloso para o imaginário de gerações e gerações de poetas nela não nascidos" ${ }^{493}$ como Ovídio, Góngora, Goethe - observamos que há um elo entre o que talvez possa representar a Sicília para Murilo Mendes e o percurso mineiro de Aleijadinho para Ungaretti. O poeta nascido em Alexandria cita, noutra carta, o fascínio e o espanto pelos territórios que o inspiram, a medida e desmedida:

Se pudesse dispor de mais tempo, poderíamos descer até a Sicília. Veríamos as coisas coisas mais lindas do mundo. Talvez até a paisagem mais linda, ainda que a estejam destruindo. $\mathrm{O}$ italiano tem uma paisagem, exceto talvez a da montanha, de uma medida e altura para o homem, é uma paisagem de graça, mesmo quando é trágica. A paisagem brasileira é, ao contrário, enorme, não na medida humana, belíssima pela sua violência é um monstro belíssimo, de natureza desmedida. O Mediterrâneo, mesmo quando banha a África, e possui o deserto, dita medida, exige medida. ${ }^{494}$

Murilo Mendes publica seu primeiro livro italiano a partir desta vivência siciliana, num cenário que, segundo Costa, "se tornaria o seu”; o livro, prefaciado por Ungà, “[... .] oferece uma boa amostragem do poeta brasileiro no momento em que encara o outro do Velho Mundo num momento privilegiado em sua vida e carreira. ${ }^{.495} \mathrm{Na}$ perspectiva analítica de Horácio Costa, a palavra cosmopolita ${ }^{496}$ não é a mais adequada para descrever a poesia de Murilo Mendes a partir dessa publicação, pois, seguindo seu raciocínio, podemos traçar um paralelo entre o modus operandi do poeta mineiro e do poeta de Alexandria. Frisamos aqui tanto a disposição de confrontar-se com a tradição clássica, como por exemplo

\footnotetext{
492 Carta n. $^{\circ}$ 38, datada de 23 de novembro de 1966.

${ }^{493}$ COSTA, H. Frente ao oráculo: Murilo Mendes escreve Siciliana. Via Atlântica. N. 15, 24 jun. 2006, pp. 267-274.

${ }^{494}$ Carta n. ${ }^{\circ}$ 198, datada de 19 de agosto de 1967.

495 Ibid.

496 "Bem mais do que considerá-la simplesmente cosmopolita, pelo ranço semântico de mundanidade remanescente nessa expressão, o que sublinho aqui é que a escrita de Siciliana origina-se numa postura diferente, que se amalgama no encontro de uma certa subjetividade com um locus que possibilitou o seu exercício em nível ótimo” (Ibid., p. 271).
} 
Ungaretti em seus livros Sentimento del Tempo e Taccuino del Vecchio, como a de escolher um caminho que se trilha sobre- ou em diálogo com — um topoi barroco. Desta forma a observação de Costa sobre o livro de Mendes poderia ser sustentada também para pensar o encontro de Ungaretti com os temas e os sentimentos provocados durante as suas passagens pelo Brasil, tanto nos anos em que aqui viveu com sua família, lecionou, perdeu seu filho Antonietto, quanto na vivência tardia em companhia de Bruna Bianco. Ungaretti, num movimento de redescoberta do Brasil e do Barroco, também se insere como uma singularidade num locus em que forjou, no final dos anos de 1930 e começo dos de 1940, um pensamento crítico sobre a língua e a literatura italiana enquanto lecionava na USP, e mais tarde nos anos de 1966 a 1969, enquanto organizava a sua obra completa, escrevia para Bruna e voltava à poesia com a composição das líricas de Dialogo.

Segundo Costa, o que possibilitou a escrita de Siciliana foi o "encontro de certa subjetividade com um locus que possibilitou o seu exercício", ${ }^{997}$ e afere que:

Essa questão não vem expressada simplesmente pelo tópico de um indivíduo representativo de uma cultura nova que se defronta com outra antiga; mais ainda, ela não pode ser relacionada ao bipolar e superestimado debate modernismo versus classicismo - ou América versus Europa - , no que tange aos temas que implica. ${ }^{498}$

Para Costa, o livro de Murilo Mendes se "dirige a assuntos humanos fundamentais". ${ }^{499}$ No poema Ruinas de Selinunte, por exemplo, surgem temas caros também a Ungaretti: Mendes tangencia o sentimento barroco em que se alternam "a catástrofe como destino; beleza como tragédia; beleza e morte; dor e êxtase" 500 — como vimos anteriormente em Walter Benjamin, quando descreve "o fragmento significativo, o estilhaço" como "a matéria mais nobre da criação barroca". ${ }^{501}$ O poeta juiz-forano observa as ruínas gregas: "Correspondendo a fragmentos de astros, / A corpos transviados de gigantes, / A formas elaboradas no futuro, / Severas tombando / Sobre o mar em linha azul, as ruínas" ${ }^{\prime 502}$ — formas quase sobrenaturais do passado que tomam corpo e vida, versos que podem compartilhar a lente de observação barroca de Ungaretti quando descreve as órbitas vazias do Coliseu no poema "Defunti su montagne" que transcreve para Bruna do livro Il Dolore: "Poche cose mi restano visibili / E, per sempre, l'Aprile /Trascinante la nuvola insolubile, /Ma

\footnotetext{
497 Ibid.

498 COSTA, H. Frente ao oráculo: Murilo Mendes escreve Siciliana. Via Atlântica. N. 15, 24 jun. 2006, p. 271.

499 Ibid.

500 Ibid.

${ }^{501}$ BENJAMIN, Walter. A origem do drama barroco alemão. Tradução de Sergio Paulo Rouanet. São Paulo: Editora Brasiliense, 1984.

502 MENDES, Murilo. Siciliana + Tempos espanhóis. São Paulo: Cosac Naif, 2013.
} 
d'improvviso splendido: /Pallore, al Colosseo /Su estremi fumi emerso,/ Col precipizio alle orbite/ D’un azzurro che sorte più non desta eccita/ Né turba." ${ }^{503}$ Ungà e Mendes, com suas singularidades, se colocam diante e dentro da História, observam suas marcas, misturam-se aos objetos e sobre eles refletem; no poema "Ruinas de Selinunte": "Nossa medida de humanos/ — Medida desmesurada — /Em Selinunte se exprime: /Para a catástrofe, em busca /Da sobrevivência, nascemos",;04 e com um tom semelhante, em quase todo o livro Il Dolore, uma reinvção e reapropriação do Barroco, Ungaretti compõe "Il tempo è muto": "Protesto invanto sull'orlo dei ricordi, Cadere forse fu mercê.../ Non seppe / Ch'è la stessa illusione mondo e mente, / Che nel mistero delle proprie onde/ Ogni terrena voce fa naufragio". ${ }^{505} \mathrm{Um}$ fio condutor desde o Infinito de Leopardi, com seu dolce naufragar, surge como costura aparente, tanto em Ungaretti como em Mendes, nos dois poemas citados.

Há uma observação de Stegagno Picchio, recuperada por Maria Betânia Amoroso em seu livro "Murilo Mendes o poeta brasileiro de Roma", para uma nova leitura do poeta mineiro que poderia, em alguma medida, irmanar o fazer poético compartilhado com Ungà, ou seja "a construção de um rigoroso particular realismo que se faz pela explicitação de uma verdade pessoal, individualmente buscada"; e continua: " para constituí-la, Murilo procura novos sentidos no universo das ideias — das mais espirituais às mais concretas de um mundo prosaico e cotidiano, reconhecível enquanto choque do real, mesmo quando há disparidade entre os universos de sentido aproximados pelas palavras díspares". ${ }^{506}$

Analisamos anteriormente de que forma o Barroco surge nas cartas a Bruna, ora como referência literária, ora como comentário aos poemas da jovem, ora como lembrança dos anos passados no Brasil e elaboração de um pensamento. Ao nos debruçarmos agora com mais afinco à constelação de nomes e referências de artistas e intelectuais brasileiros que surge nas cartas à jovem aspirante a poeta, podemos caminhar, a partir do retrato em versos que Murilo Mendes oferece do poeta nascido em Alexandria, em direção aos vestígios que surgem nas missivas. Há o nome de outro mineiro se surge nas conversas com Bruna, um artista que tanto capturou a atenção de Giuseppe Ungaretti: Antonio Francisco Lisboa, o Aleijadinho. Antonio Candido relembra que:

[...] um dos seus maiores desejos [de Ungaretti] era o de ver pessoalmente as esculturas de Aleijadinho, cujas fotos tinham provocado tanto

\footnotetext{
${ }^{503}$ Carta n. ${ }^{\circ}$ 12, datada de 11 de outubro de 1966.

504 MENDES, Murilo. Siciliana + Tempos espanhóis. São Paulo: Cosac Naif, 2013.

505 UNGARETTT, Giuseppe. Vita d'un Uomo. Tute le Poesie. Op. cit. p. 253.

506 Apud AMOROSO, Maria Betânia. Murilo Mendes o Poeta Brasileiro de Roma. São Paulo: Editora UNESP, 2013, p. 108.
} 
entusiamos. Mas as comunicações, então, eram difíceis e ele acabou indo embora sem realizar este desejo, fazendo-o somente em 1966 quando voltou com Alfredo Bosi, cujo cunhado, o sociólogo Celso Frederico, os acompanhou de carro até lá. 507

Segundo Bosi, o poeta teria exclamado, quando finalmente chegaram a Congonhas: "os profetas do Aleijadinho não são barrocos, são bíblicos"; 508 nas cartas a Bruna, Ungaretti escreve sobre o seu desejo de conhecer de perto a obra do artista mineiro — "uma tão longa permanência me pemite voltar nos lugares de Aleijadinho, e ir até a Bahia e Recife". ${ }^{509}$ Em Il deserto e dopo, em nota introdutória às traduções de Tomaz Antonio Gonzaga, Ungaretti faz uma apresentação da Serra do Espinhaço, escrevendo: "un succedersi di dentacci, di un'altezza a volte di due chilometri, forma, in un mare di verde da Mezzogiorno a Settentrione risalendo da San Paolo, una muravglia rettilinea graffiata da unghie millenarie", e então, emergindo da vegetação introduz Aleijadinho e o triângulo mineiro de São João delRei, Ouro Preto e Mariana:

Quei minuscoli nuclei presto avranno l'opulenza di case graziose e di chiese e di statue dovute al genio d'uno scultore mulatto, atrocemente patetico, l'Aleijadinho che, come dice il suo nome, perdeva il corpo, morso dalla lebbra, falange per falange, arto per arto. Ma non smise mai di lavorare, e si faceva da ultimo legare ai moncherini il mazzuolo e lo scalpello. 510

Em entrevista concedida a Augusto Massi em 1996, Bruna relata a apaixão de Ungaretti pelo artista e descreve um pouco da viagem que fizeram juntos em 1966:

[...] fizemos uma viagem pelo Brasil. Fomos a Minas Gerais, onde visitamos Ouro Preto, Congonhas e Sabará. Para não cansá-lo, a cada manhã saíamos para visitar uma das cidades históricas, retornando à noite para Belo Horizonte. Numa daquelas noites, jantamos com a poeta Henriqueta Lisboa. Em todas as viagens fomos acompanhados pelo crítico Geraldo Magalhães. Durante dez dias, estudamos atentamente o barroco mineiro e vimos grande parte dos trabalhos de Aleijadinho. Como ele gostava do Aleijadinho! Achava quase impossível a ausência de uma escola ou de uma academia na sua formação, embora reconhecesse que estava acima dos artistas de seu tempo. Tinha uma teoria curiosa sobre o sensualismo do Aleijadinho, chegando a afirmar com segurança que era homossexual como Michelangelo. Dentre todas as suas obras - descartava muitas das que lhe eram atribuídas - a que mais admirava era a dos púlpitos da Igreja do Carmo, em Sabará. ${ }^{511}$

\footnotetext{
${ }^{507}$ CANDIDO, Antonio. Ungaretti em São Paulo. Estud. av. Vol. 8. N. 22. São Paulo, Sept./Dec. 1994 (http://www.scielo.br/pdf/ea/v8n22/25.pdf, consultado em 12 de agosto de 2015. 508 BOSI, Alfredo. Dialética da colonização. São Paulo: Companhia das Letras, 2001.

${ }^{509}$ Carta n. ${ }^{\circ}$ 62, datada de 18 de dezembro de 1966.

510 UNGARETTI, Giuseppe. Vita d'un uomo. Viaggi e Lezioni. A cura di Paola Montefoschi. Milão: Mondadori, 2001, p. 386.

511 MASSI, Augusto. “A paixão do mestre Ungà”. Folha de São Paulo, 21 de julho de 1966.
} 
A leitura de Ungaretti da obra de Aleijadinho, nos poucos vestígios que se encontram como citamos - é claramente informada tanto por uma apropriação romântica do artista e de sua vida, quanto pelo crivo de uma visão informada por sua fé. O mesmo olhar que destina a outros artistas, como já citamos, e para o mundo. Quando lemos a descrição de Aleijadinho escrita pelo poeta e relembramos a carta em que fala de Picasso, especificamente do retrato de Renoir desenhado por Picasso, podemos ter acesso à visão do mundo de Ungaretti. Esse tom é o que atravessa as cartas a Bruna, mas é muito mais do que simplesmente um tom professoral, muito mais do que um mestre falando com uma pupila - ainda que possamos ler as cartas a Bruna também como um manual de escrita, em certos momentos — há um espaço possível que emerge para o próprio desenvolvimento do pensamento do poeta. Sobre o arquiteto e escultor mineiro, ele escreve: "Aleijadinho que, como diz seu nome, perdia o corpo, mordido pela lepra, falange por falange, membro por membro. Mas nunca parou de trabalhar, fazia-se no final amarrar aos cotos o malho e o cinzel", ${ }^{12}$ e na Carta n. ${ }^{\circ} 41$, ao falar de Renoir:

Vejo o retrato de Renoir, com aqueles punhos fechados pela artrite nos quais se fazia atar os pincéis, para pintar aqueles nus das serviçais adolescentes, que estavam, quando łos os vi, aqui em Paris, logo após a guerra, em 1920, no Bernheim Jeune, ainda de uma cor tomate atroz. Olha os olhos de Renoir, aquele velho Renoir que pintava com luxúria insuportável as garotinhas peitudas, os olhos vazios de Renoir, já vazios, com a morte no fundo, a "volupté et la morte". E o ombro que se inclina de um lado. É a mais verdadeira obra de Picasso. ${ }^{513}$

Exalta em ambos a doença, a velhice e a obsessiva busca por uma verdade no artefato da própria arte. Leitor da obra de outros artistas, já no final de sua vida, é como se Ungaretti observasse a si mesmo através do mesmo espelho opaco, o espelho de Mallarmé, que ele mesmo cita - o poeta para quem a poesia é um segredo comunicado em segredo observa o mundo misturando-se a ele, fazendo uso de outras representações artísticas para construir o seu entendimento de mundo, para construir a sua verdade. Outra figura que surge nas cartas a Bruna, ainda quando escreve sobre Aleijadinho, é Lourival Machado. Trata-se provavelmente do período em que Machado organizava a obra Barroco Mineiro. ${ }^{514}$ O crítico de arte e historiador foi aluno de Ungaretti e um dos fundadores da revista Clima. Ungà se refere a ele em dois breves comentários, com pouca distância entre um e outro: "hoje almoço com Lourival Machado, alto funcionário da Unesco, historiador do

\footnotetext{
512 UNGARETTII, Giuseppe. Vita d'un uomo. Viaggi e Lezioni. Milano: Mondadori, 2000, p. 286.

${ }^{514}$ MACHADO, Lourival G. Barroco Mineiro. São Paulo: Perspectiva, 1969, reed. 2003.
} 
Aleijadinho, meu antigo discípulo na Faculdade de Letras da Universidade onde então se tornou professor"; ${ }^{515}$ e em seguida, dois meses mais tarde, escreve à amada dando a triste notíca da morte do jovem amigo:

Hoje ao meio-dia na capela do aeroporto, assisti, em presença do corpo, à missa para Lourival Machado. Foi um dos meus melhores alunos, nos anos em que lecionei no Brasil. Não tinha mais do que 50 anos. Escreveu o melhor livro sobre Aleijadinho. Se ocupava de história da arte com sempre maior paixão e competência. Estava na Itália devido à ajuda recolhida pela Unesco para a restauração de Florença e Veneza. Veneza está muito ameaçada. Era um dos altos funcionários da Unesco. Há poucos dias tínhamos almoçado juntos. Pobre querido amigo. Todos os meus amigos brasileiros the eram próximos, como eu. Estou muito dolorido. 516

Lourival Machado fazia parte do grupo de alunos e amigos que Ungaretti havia formado durante seus anos em São Paulo. Entre os amigos mais próximos havia Paulo Emílio Sales Gomes - que apresentou Antonio Candido ao poeta - e Italo Bettarello, que foi, naqueles anos, seu assistente. Em algumas cartas, Ungaretti pergunta para Bruna se tem notícias de Paulo Emílio e de Lygia, provavelmente se encontravam com frequência também nas viagens em que retornou para encontrar sua amada Bruna. Em sua entrevista a Augsto Massi, diz que quando entrou no hotel Ca' d'Oro para entregar seus poemas a Ungaretti, quando se viram pela primeira vez, estavam juntos: “[...] lembro que estavam com ele o Paulo Emílio Sales Gomes, a Lygia Fagundes Telles, o Di Cavalcanti, o Flávio de Carvalho e a família do Sérgio Buarque de Holanda ${ }^{517}$ Em setembro de 1967, de volta à Itália, após a viagem feita por Minas e Bahia, Ungaretti relembra com Bruna um episódio que causoulhe algum constrangimento - não fica muito claro, mas ele parece aludir a algum comentário maldoso feito em relação à diferença de idade que os separava. Não é muito claro de quem poderia se tratar, talvez Geraldo Magalhães, mas certamente alguém que lhe fora apresentado por Paulo Emílio, e como escreveu o poeta, purtroppo, sendo o professor e o cineasta "uno dei miei più cari amici". 518

Quando Ungaretti retorna em 1967, para receber o título de doutor bonoris causa, numa visita à Universidade de São Paulo, encontra amigos professores e outros intelectuais, existindo um raro e preciso registro cinematográfico desse momento, recentemente publicado no canal do IEB na plataforma YouTube, editado pelo professor Carlos Augusto Calil, com o título Encontro de Paulo Emílio com Giuseppe Ungaretti. Pudemos consultá-

\footnotetext{
515 Carta n. ${ }^{\circ} 115$, datada de 11 de fevereiro de 1967.

516 Carta n. ${ }^{\circ} 137$, datada de 21 de março de 1967.

517 MASSI, Augusto. “A paixão do mestre Ungà”. Folha de São Paulo, 21 de julho de 1966.

518 Carta n. ${ }^{\circ} 206$, datada de 4 de setembro de 1967.
} 
lo, antes de sua publicação, pela primeira vez, em 2012, com a ajuda da professora Lucia Wataghin, que nos cedeu o material durante o nosso trabalho de curadoria da exposição "Daquela estrela a outra" realizada na Casa das Rosas em São Paulo por ocasião do sesquicentenário da unificação italiana. A abertura do vídeo editado traz uma bela citação de Paulo Emílio, na qual se lê: “[...] é à Universidade que devemos um dos mais belos acontecimentos de nossas vidas, o de termos vivido aquecidos e iluminados pela presença em nossa cidade de Giuseppe Ungaretti”. ${ }^{519}$ Segundo Calil:

Paulo Emílio, que lhe devotava [a Ungaretti] afeto filial, levou-o até a entrada do IEB, situada no edifício da História e Geografia para uma entrevista filmada. Convocou David Neves, na câmera $16 \mathrm{~mm}$, e Sérgio Muniz, no gravador Nagra, para o registro. Convidou Bruna Bianco, que acabava de voltar de uma viagem a Minas e à Bahia, feita na companhia do visitante ilustre Rudá de Andrade, que havia sido noivo da filha do poeta Haroldo de Campos, Alfredo e Ecléa Bosi e Décio de Almeida Prado para recepcionarem Ungaretti e ouvi-lo declamar suas traduções do Pau-Brasil, de Oswald de Andrade. ${ }^{520}$

Muitas vezes, ao lidar com cartas e meticolosos fragmentos de informações, nos deparamos com pequenas imprecisões e estranhezas. Haroldo de Campos, citado por Calil, não teve nenhuma filha, mas teve, sim, um filho, Ivan. A partir dessa pequena nota do professor Calil, passamos a reconstruir os fatos, com vistas a entender quem teria sido a misteriosa noiva de Rudá de Andrade. Trata-se com efeito de uma noiva italiana, sim, filha de poeta, mas não de poeta brasileiro. Rudá de Andrade, ${ }^{521}$ filho de Oswald e Pagu, havia se relacionado com Anna Maria, conhecida como Ninon, filha de Giuseppe Ungaretti. Num artigo em que conta a sua trajetória, a jornalista Norma Couri escreve:

Em 1954, [Rudá] veio ao Brasil visitar o pai. Mas Oswald morreu nesse ano (aos 64 anos) e Rudá nunca mais retornou à Itália. Deixou para trás uma noiva, filha do poeta Giuseppe Ungaretti. "Ele veio passar uma temporada no Brasil e me interpelou: Perché?", lembrou Rudá. "Como eu não tinha mesmo o que dizer, apelei: La vita è cosi, maestro." A vida é assim, mestre. ${ }^{522}$

No vídeo, Paulo Emílio pergunta ao poeta se ele conhecia algo do cinema brasileiro, e Ungà então lhe responde com a mesma energia com que declama seus versos, cabendo

\footnotetext{
519 Paulo Emílio encontra Giuseppe Ungaretti, IEB, 2016 (https://www.you-

tube.com/watch?v=KeL3NKjXXN0\&t=129s, consultado em 15 de março de 2017.

520 http://www.ieb.usp.br/wp-content/uploads/sites/127/2017/04/informe-4-IEB-edi\%CC3\%A7\%C3\%A3o-4.pdf consultado em 10 de abril de 2019.

521 Rudá Galvão de Andrade (1930-2009), cineasta e escritor, estudou no Centro Experimental de Cinematografia, em Roma, onde foi assistente de direção de Vittorio de Sica.

522 COURI, Norma. La vita è così, maestro. Seção Despedida. Piauí. Ed. 30 https://piaui.folha.uol.com.br/materia/lavita-e-cosi-maestro/, consultado em 10 de abril de 2019.
} 
bem na descrição que Ruy Coelho faz do mestre: “[...] dava aula aos rugidos, ouviam-se os gritos pelo corredor [...] Foi o único homem cuja presença me fez sentir que estava diante de um gênio". ${ }^{523}$ Descreve uma cena que parece tê-lo impressionado muito, uma história passada "ao norte do país", diz, diante de uma situação de miséria um grupo começa a arrancar pedaços de uma vaca, o animal ainda vivo. Poderíamos pensar aqui na cena recordada por Antonio Candido:

[...] no começo de 1965 partecipamos juntos, por alguns dias, de um congresso em Gênoma, naquela ocasião estavam conosco também Murilo Mendes e Guimarães Rosa. Naquele encontro lhe entreguei as traduções de Corpo de Baile feitas por Edoardo Bizzarri e ele ficou muito entusiasmado. O congresso era em parte dedicado ao nosso Cinema Novo. Assistimos ao filme Deus e o Diabo na Terra do Sol, ao lado um do outro, ele ficou aterrorizado pelo sacrifício de uma criança por parte de fanáticos, exclamando: "Mais c'est affreux! C'est affreux ${ }^{524 ! " ~(C A N D I D O, ~}$ 1996, tradução nossa)

Mas observamos, no final do recorte montado pelo IEB, que se tratava provavelmente de Os fuzis, de Ruy Guerra. Basta ouvir o poeta, observar sua expressão, para compreender melhor qual a mitologia que se criara "em torno daquele homem barroco que deformava ao extremo a própria fala, mas que sabia articular elementos históricos dos mais profundos, indo da rara erudição à poderosa síntese dos conceitos". ${ }^{525}$ A vivacidade e a inteligência com que rapidamente passava do cinema à vivência na Bahia, de onde o poeta acabava de chegar com Bruna, na noite anterior. Sobre esse trecho da viagem Bruna, ele relembrou:

[...] viajamos até a Bahia, onde fomos hóspedes de Assis Chateaubriand, e Ungá pôde comparar o barroco baiano com o mineiro. Em Salvador foi uma festa. Jorge Amado nos apresentou a vários artistas plásticos baianos: Caribé, Mário Cravo, Emanuel Araújo. Zélia Gattai, mulher de Jorge, guardava num quartinho de sua casa uma série de trabalhos destes artistas que vendia para ajudá-los. Fomos ver o candomblé e visitamos a Mãe Menininha, a quem, impressionadíssimo, Ungá chamava de La Reine Victoria ${ }^{526 .}$

Bruna Bianco ainda carrega consigo a guia que the foi dada naquela ocasião em que visitaram o terreiro do Gantois, Ilê Axé Iyá Omin Iyamassê, diz que foi um presente confeccionado por Waldeloir Rego, então aclamado por Jorge Amado como o “ourives de Oxum” ou “joalheiro de Yemanjá” — o nome do ouvrives e etnólogo bahiano também surge numa carta a Bruna, na qual Ungà comunica à amada que enviaria ao amigo o livro de que

${ }^{523}$ MASSI, Augusto. O leão na sala de aula. Folha de São Paulo, 21 de julho de 1996.

524 "Mas é terrível!"

525 MASSI, Augusto. O leão na sala de aula. Folha de São Paulo, 21 de julho de 1996.

526 MASSI, Augusto. “A paixão do mestre Ungà”. Folha de São Paulo, 21 de julho de 1966. 
precisava. No vídeo, Ungaretti diz ser filho de Oxalá e Omolu, assim como havia escrito ao seu querido pupilo, Leone Piccioni:

[...] estive por uns dez dias na Bahia, visitei a região. Bruna e sua avó me acompanharam. Descobri uma infintude de coisas. Fomos, os três, iniciados aos rituais do Candomblé e agora estou sob a tutela de Oxalá, entidade ou feitiço da criação e Omolú, patrão do mundo e curandeiro. 527

É o poeta interessado pelos mitos da origem, o mesmo que selecionou as favole indie para a sua antologia de poesia brasileira. Ele repete isso - a origem do mundo - algumas vezes no vídeo, e também continua, na mesma carta para Piccioni:

[...] claro tudo isso não é nada mais do que uma brincadeira do ponto de vista da fé; mas nos permitiu entrar nos segredos, de um povo, que remontam aos primeiros momentos humanos. São claro os mitos de origem, os deles, que se encontram, num aspecto renovado segundo os tempos, em toda poesia digna deste nome. 528

$\mathrm{Na}$ filmagem, relata ter proferido uma palestra sobre Dante Alighieri na Bahia, e diz ter escolhido comentar o décimo canto do Paraíso. Paulo Emílio lhe pergunta: "falou de Dante, falou sobre justiça?" - pergunta essa que nos remete a um trecho de suas anotações de uma aula proferida no Brasil, em Lez̧ioni brasiliane, quando Ungaretti escreve: "Dante ha scritto la Commedia per mostrarci che il fine dell'uomo è la giustizia, e che l'uomo vi tende come persona, e che vi tende come società umana, e che vi tende come genere umano in tutto il suo percorso storico". ${ }^{229}$ Ungà cita com rápida desenvoltura temas presentes tanto nos cantos décimo como no décimo-primeiro do Paraíso da Comédia; fala de São Tomás de Aquino, mas fala também da exaltação da pobreza, com São Francisco (canto décimo-primeiro). Lemos no décimo canto do Paraíso uma confluência de luzes cintilantes, pois é cada vez maior a proximidade à intensa luz do sol. Há a dificuldade de descrever tamanha luminosidade em palavras, em Dante, há algo inexprimível nesse canto que Ungà escolhe comentar; em sua busca pela luz, algo reverbera de "quel nulla d'inesauribile segreto", "a manhã que o deslumbra de imenso" (em tradução de Haroldo de Campos). Com esta pequena divagação a partir da gravação em vídeo do poeta que perambula pelos corredores da universidade, caminhando e falando de forma extemporânea, é importante também recordarmos as palavras de Luciano Rebay: "Ungaretti non è né un filologo

527 UNGARETTI, Giuseppe. Carta n. ${ }^{\circ} 263$. In L'allegria è il mio elemento. Trecendo lettere con Leone Piccioni. Milão: Mondadori, 2013, p. 304-305, tradução nossa.

528 Ibid.

${ }^{529}$ UNGARETTI, Giuseppe. Lezioni Brasiliane. Organização de Paola Montefoschi. Op. cit., p. 153. 
né un critico nel senso 'professionale' del termine: è un poeta, e un'opera letteraria gli interessa per la possibilità di riconoscervi dei rapporti, delle affinità, con la propria poesia e la propria persona". ${ }^{530}$ No fundo, Ungaretti é sempre e mais do que qualquer outra coisa um poeta, um poeta que reflete e questiona, mas que está em busca de relações e refrações de si e de sua busca, seu olhar se dirige a outras obras sempre permeado pelo desejo de um diálogo íntimo com sua próprias questões.

Paulo Emílio e Lygia surgem mais uma vez, em duas cartas: Ungaretti estava em Paris e encontra-os por acaso, marcam um almoço e tudo é relatado a Bruna com atenção e carinho, por um lado, e, por outro, com o sentimento crítico que acompanha Ungaretti em todas ocasiões, até com uma pitada de rudeza - comentando exposições, mini-saias, sapatos, música, a beleza ou feiura de quem cruzava seu caminho e estava à sua mesa:

No aeroporto, enquanto esperava a mala, com o encarregado da embaixada que tinha vindo me receber, se coloca na minha frente Paulo Emílio, alto como o Colosso de Rodi, e depois também Lygia. Pegaram meu endereço, me fizeram mil festas, mas ainda não sei o que vieram fazer em Paris ou onde estão hospedados. Perguntarei esta manhã informações à delegação brasileira. ${ }^{531}$

Com Paulo Emílio e Lygia, veio almoçar conosco uma Senhora jovem, de cultura atualizada, e que me indicou o artigo de Mandiarques no Nowvelle Observateur em que a propósito do inesquecível, querido, querido, Paulhan, sou lembrado. Senhora belíssima. Estivemos com Paulo Emílio na exposição de uma pintora brasileira. Bela pintura talvez, não entendo muito. Perdoa-me, mas tirando a Senhora, que falei acima, belíssima, a aparência de todos os teus compatriotas de escolha era quase em todos impossível de olhar, entre as feias típicas. Talvez em São Paulo também se vejam outras. Tem tu, não, belíssima, amorino, e teus irmãos. ${ }^{532}$

Com um toque ferino em algumn aspectos, o poeta não mede elogios, porém, ao falar de João Guimarães Rosa:

É um ano escasso de bons livros. Não há nenhum que seja realmente extraordinário. Na Itália de romancistas de primeiríssima ordem não há se não Gadda (Moravia, se quiser). São escritores velhos. No Brasil há um grande romancista: Guimarães Rosa. É um dos 3 ou 4 primeiros do mundo. ${ }^{533}$

Relembramos anteriormente, no depoimento de Antonio Candido, que Ungaretti, Candido, Murilo Mendes e Guimarães Rosa estiveram juntos por alguns dias durante um congresso em Gênova no começo do ano de 1965. Esse encontro foi documentado por um cartão postal

\footnotetext{
${ }_{530}$ REBAY, Luciano. Le origini dela poesia di Giuseppe Ungaretti. Roma: Edizioni di Storia e Letteratura, 1962, p. 154.

531 Carta n. ${ }^{\circ} 330$, datada de 23 de outubro de 1968.

532 Carta n. ${ }^{\circ} 331$, datada de 26 de outubro de 1968.

${ }^{533}$ Carta n. $^{\circ} 161$, datada de 6 de julho de 1967.
} 
enviado ao então diretor do Instituto Italiano de Cultura e tradutor de Rosa, Edoardo Bizzarri: ${ }^{534}$ "Relembrando-o com muito afeto/ Ungaretti / A sua tradução de Corpo de Baile (Guimarães Rosa) é belíssima" ${ }^{335}$ e "Caro Bizzarri: com grande emoção vi nas vitrines das livrarias a sua admirável tradução revelando um grande homem aos italianos. Grande abraço Antonio Candido" ${ }^{536}$ Guimarães, assim como Candido, também contribuiu com um depoimento para a edição especial da revista L'Herne dedicada a Ungaretti:

Dizia-te no telegrama, que as festas seriam duas em setembro aquela em Zurique, pela publicação do meu livro ilustrado por Dorazio, e aquela de Paris, pela saída do grande volume L'Herne que me foi dedicado como homenagem com escritores do mundo inteiro. Há também os brasileiros, Jorge Amado, Candido, outros, até o saudoso Guimarães Rosa que teve tempo de mandar um texto. Querido, grande Guimarães Rosa. ${ }^{537}$

Oswald, Chico e Vinícius povoam tantas outras cartas escritas a Bruna, num movimento contínuo de aproximação de mundos — não só a Itália e o Brasil, não só de duas línguas, mas de vivências de um poeta quase octagenário e de uma jovem advogada aspirante a poeta - havento em comum, no fundo, um sentimento de desenraizamento que habitava ambos. Ungaretti permeia suas narrativas do cotidiano com planos para o futuro, com relatos minuciosos do andamento de seus trabalhos, e se mostra sempre à procura de um cadean para sua amada, relógios, pequenos objetos, perfurmes caléche, lenços hermès, quadros de Fautrier e Cagli e até Di Cavalcanti: “Comprarei para Ti em São Paulo, o Di Cavalcanti que desejas? O conheces pessoalmente? Gostarías de estarmos uma vez à mesa juntos?"538 Em janeiro de 1969, já com alguma mudança de tom nas cartas enviadas por Ungaretti, surge uma anedota interssante, ou seja, o encontro de Ungaretti com Cutolo, que viria a ser o tradutor do livro de Oswald, Memorie sentimentali di Giovanni Miramare, ${ }^{539}$ prefaciado pelo poeta e publicado pela Feltrinelli. Ungà começa a carta do dia dizendo:

Piccolina, há uma multidão de Brasileiros: Vinícius, Chico, outros, e passo frequentemente horas com eles. Hoje veio me ver um certo Cutolo que vai morar na Tailândia [...] para ser representante, como já foi no Brasil, de uma empresa farmacêutica italiana. Durante sua permanência em São Paulo se ocupou de Osvaldo de Andrade, e agora prepara a edição italiana das obras (Feltrinelli Editore), à qual, por desejo seu, vou me permitir um pequeno discurso. ${ }^{540}$

\footnotetext{
${ }^{534}$ Correspondência reunida em BIZZARRI, Edoardo. UNGARETTI, Giuseppe. Cartas Lettere 1966-7. Organizado e traduzido por Francesca Cricelli. São Paulo: Scritporium, 2013, p. 27.

535 Ibid.

536 Ibid.

537 Carta n. ${ }^{\circ} 285$, datada de 15 de maio de 1968.

538 Carta n. ${ }^{\circ} 301$, datada de 16 de junho de 1968.

539 ANDRADE, Oswald de. Memorie sentimental di Giovanni Miramare. Tradução italiana de Giovanni Cutolo.

Prefácio de Giuseppe Ungaretti. Milão: Feltrinelli, 1970.

${ }^{540}$ Carta n. $^{\circ}$ 354, datada de 9 de janeiro de 1969.
} 
Há poucos vestígios da passagem de Cutolo pelo Brasil, mas resta o fato interssante de ele haver traduzido Oswald de Andrade para o italiano e Obra aberta ${ }^{541}$ de Umberto Eco para o português. Além disso, em seu período brasileiro, entre 1965 e 1968, parece ter militado ao lado de Carlos Marighella. ${ }^{542}$ Sobre o tradutor, Ungaretti tece o seguinte simpático comentário em seu prefácio:

Agora deveria louvar o tradutor, aquele jovem audacioso que aprendeu a usar um migalhinha da sagacidade de Osvaldo, tanto que se pôs a fazer nem sei mais qual trabalho num país circunloquente, como o Siam, construído feito uma renda e no qual o clima deve ser intolerável até para a pele de elefante. Queria que o encontrasse para umas férias, e é verdade que sou capaz de qualquer coisa mesmo tendo dezesseis vezes o lustro, aquele meu lustro que, aí, nunca supera um lustro. Seria uma boa hora para que Cutolo voltasse para a Itália; por mérito seu lembramos também por aqui o nosso extraordinário amigo Osvaldo. ${ }^{53}$

Os vínculos literários de Ungaretti, no Brasil, são sempre permeados por um afeto profundo, e todo o comentário parece deixar isso muito claro. Ainda que escreva "ma dove Osvaldo è Osvaldo é nella poesia detta in versi", ${ }^{544}$ Ungà faz um retrato de Oswald permeado de uma linguagem que roça o fantástico e que não deixa para trás o elemento literário: se por um lado “[...] non ebbero più donne Abramo, né Matusalemme né Noè messi insieme, che devono averne godute moltitudini per popolare o ripopolare questio pianetaccio", por outro, cita Pignatari: "Decio [...] che le sa queste cose a menadito ci insegna che il selvaggio significò per Osvaldo ciò che Confucio significava per Pound: la visione di una nuova morale non cristiana e di un nuovo linguaggio diretto, ideogrammico". Em suas reflexões sobre a tradução e sobre o fazer da poesia, ecoa, em Ungaretti, um sentido amplo de liberdade no que diz respeito à definição da poesia: "I modi della poesia sono infiniti, come quelli della pittura, e c'è posto nel mondo per Raffaello come per Picasso". .54

Tentamos apresentar uma cartografia possível para navegar o rio caudaloso de cartas de amor que Ungaretti devota à sua amada Bruna. Há, provavelmente, muitas outras possibilidades interpretativas, mas nossa intenção foi oferecer um percurso que abrisse um caminho através

\footnotetext{
${ }^{541}$ ECO, Umberto. Obra aberta: forma e indeterminação nas poéticas contemporâneas. Tradução de Giovanni Cutolo. São Paulo: Perspectiva, 2001.

542 Biografia do tradutor, segundo sua editora Aracne Edizioni (http://www.aracneeditrice.it/index.php/autori.html?auth-id=340284, consultado em 5 de fevereiro de 2019).

543 LANCIANI, Giulia (org.). Il Brasile di Ungaretti. Roma: Istituto Poligrafico e Zecca dello Stato, 2003, p. 17.

544 Prefácio reproduzido em Il Brasile di Ungaretti. Curado por LANCIANI, Giulia. Roma: Istituto Poligrafico e Zecca dello Stato, Libri e Riviste d'Italia No. 52, 2003, p. 17.

545 UNGARETTI, Giuseppe. "Sulla Fedra di Racine”. In Vita d'Un Uomo. Saggi e Interventi. Op. cit., p. 577.
} 
dessa mata de juras de amor e descrições minuciosas do cotidiano de alguns temas que se repetem, como espiral, e voltam a se propor à interlocutora com roupagem semelhante, igual, diferente. Os temas estão presentes em todo o percurso das missivas, em suas cinco divisões, mas a maior intensidade de descrição de temas está presente na primeira parte da correspondência, ou seja, o período que vai do dia em que se separaram até o primeiro reencontro. Neste momento há uma força motriz da criação poética, começa a nascer o livro Dialogo, enviam-se as traduções de poemas, por parte de Ungaretti, na tentativa de voltar à escrita de poesia após um hiato de seis anos. Há correções meticulosas, por parte do mestre, nos versos da jovem amada, há uma espécie de laboratório de criação sobre a escrita da poesia, reflexão sobre a língua, questões de tradução. Tudo isso é o que tentamos privilegiar em nossa leitura e em nosso recorte apresentado nessa tese, com a intenção também de servir ao nosso propósito. Os temas se repetem nas outras divisões, ora com a mesma intensidade, ora com menos força, e por isso privilegiamos os primeiros meses de correspondência em nossa análise. Argumentos sobre a língua italiana e o tema da luz também percorrem nosso recorte. Entre os textos escolhidos e traduzidos, há algumas crônicas impactantes de suas viagens, como a ida a Israel e a Londres. Paris é quase uma personagem constante nestes anos, sua segunda casa, e está sempre presente nos intervalos de suas crônicas-missivas enviadas de Roma capital e das colinas circundantes.

Neste esforço, privilegiamos recortar e trazer à vista a qualidade do poeta que está sempre em diálogo com outros artistas, outros poetas, outras escritas, através dos seus textos críticos, suas apresentações de catálogos, suas traduções — todas as atividades que permeiam seu cotidiano enquanto ele escreve para Bruna - assim como o esforço analítico de rever sua obra e organizá-la para a publicação de Vita d'un nomo. As ideias de luz e sombra, como apropriação do que se manifesta no outro — texto, pintura, escultura - é algo que recorre também como uma espiral, num movimento análogo ao que Wataghin observa nas traduções de Ungaretti das Favole Indie della Genesi: "a ideia de voltar à luz, da revelação das coisas, em contraposição à noite" 546 é constante. Em sua tradução, Wataghin observa que, quando cai a noite, a fala "Nos perdemos!” se transmuta, na tradução de Ungaretti, em “Agora desaparecemos", portanto "Limitando o campo semântico de 'perder-se' em favor da dimensão sensorial de 'desaparecer' (porque as coisas desaparecem diante da vista), a tradução remete [...] ao renascer das coisas diante da vista" ${ }^{547}$ Essa mesma qualidade de deslumbramento parece acompanhar Ungaretti em cada carta que

\footnotetext{
546 Wataghin, Lucia. "Um mito tupi traduzido por Giuseppe Ungaretti: "Mai Pituna Oiuquau Ãna” ("Como a Noite Apareceu”)" Revista USP, São Paulo (37): 168-173, Março/Mario 1998 pp. 168-173

547 Ibid. p. 170
} 
escreve a Bruna, nas quais há sempre uma busca pela luz, uma forma de evocá-la — mia luce — que coincide com o teor de inspiração do livro feito com o artista Dorazio. Giulia Lanciani, a propósito das traduções de Ungaretti, observa o gesto do poeta que “[...] muove non alla traduzione, ma alla conquista del testo: lo scompone, lo studia e lo ricompone risemantizzato e trasferito nel proprio idioletto linguistico e culturale, lo assimila insomma alle immagini sostanziali della sua poetica" ${ }^{\text {5 }}$ — seja metro e no ritmo do verso, seja na forma de olhar para o mundo, Ungaretti é esfinge de si mesmo, e o diálogo com Bruna concentra, de forma apaixonada, um diálogo mais amplo e que o distingue, o desejo de estar em relação com o outro para perlaborar a própria poética e a indagação do seu ser. ${ }^{549}$

\footnotetext{
548 I1 Brasile di Ungaretti. Curado por LANCIANI, Giulia. Roma: Istituto Poligrafico e Zecca dello Stato, Libri e Riviste d'Italia no. 52, 2003, p. XI.

${ }^{549}$ Enfim, entre os outros encontros de Ungaretti na Universidade de São Paulo, há o professor Antônio Lázaro de Almeida Prado, que o encontrou quando esteve no Brasil nos anos de 1960. Após a defesa desta tese, sua filha, Fernanda de Almeida Prado, comentou que seu pai havia dedicado um poema em ocasião do falecimento de Ungaretti. Decidimos incluí-lo em nota ao texto. Antônio Lázaro, também poeta, foi autor da tradução de "Invenção da poesia moderna: lições de literatura no Brasil (1937-1942)", editado pela Ática em 1966, professor da USP e professor fundador da UNESP. Segue o poema:
}

\section{A Giuseppe Ungaretti}

Tenra luz

Nos olhos entrefechados

Na moldura de um sorriso irônico.

Hoje te acolhe a mãe severíssima.

E, discreta, festeja o filho que voltou.

E tudo é harmonia, grito festivo, paz.

Não mais a ânsia tenaz, a furiosa

Procura de palavras, não mais o gesto

De ferozes mãos, nem a cupidez

Do lobo insatisfeito.

Triunfa agora, um tempo novo:

Vôo festivo

De inocentes pássaros,

A trepida quietude da ovelha

E a paz que vai além dos últimos limites.

Acolhe-te Felicíssimo, Antonietto.

São Paulo, 4 de junho de 1970

Antônio Lázaro de Almeida Prado 


\section{TRADUÇÃO COMENTADA DAS CARTAS \\ PRIMEIRA PARTE \\ SETEMBRO DE 1966 - ABRIL DE 1967}

Este fragmento da correspondência marca seu início, a porção mais volumosa que separa a primeira despedida do primeiro reencontro. A base do livro Dialogo se dá nesses primeiros meses de missivas. É uma das questões fulcrais tratadas em nossa análise. São cento e quarenta e seis cartas que começam no dia 14 de setembro de 1966 e terminam no dia 4 de abril de 1967.

(Esta parte da tese não pode ser consultada por conter material sigiloso pendente de direitos autorais da Editora Mondadori) 


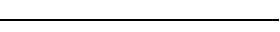

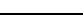




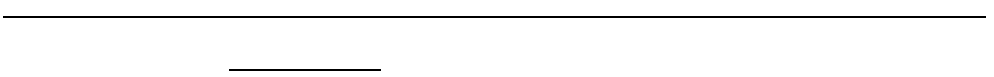


$\longrightarrow$

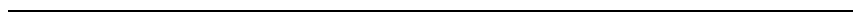

$\overline{-}$ 


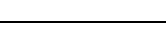

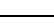

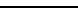




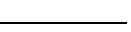

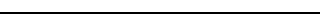


$\longrightarrow$ 


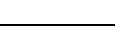

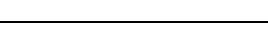




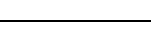



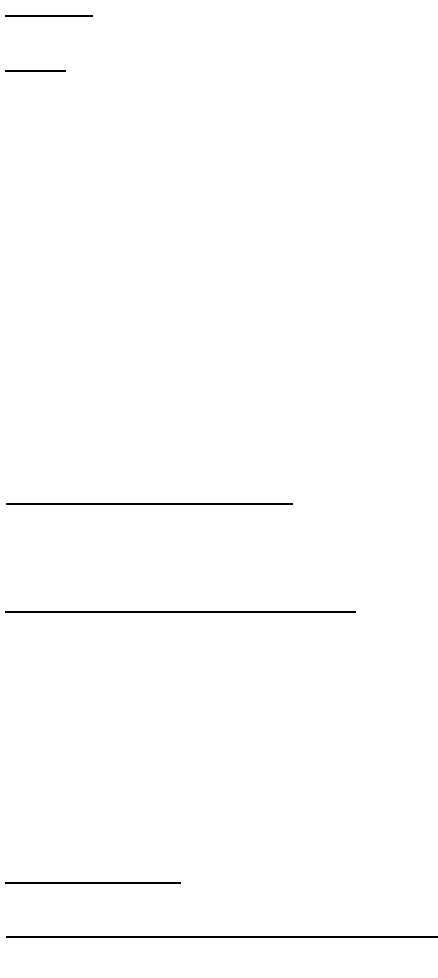
$\longrightarrow$ 


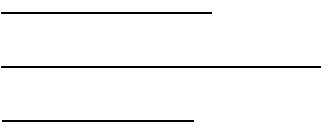

$\overline{-}$ 


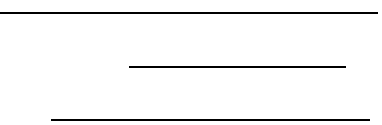




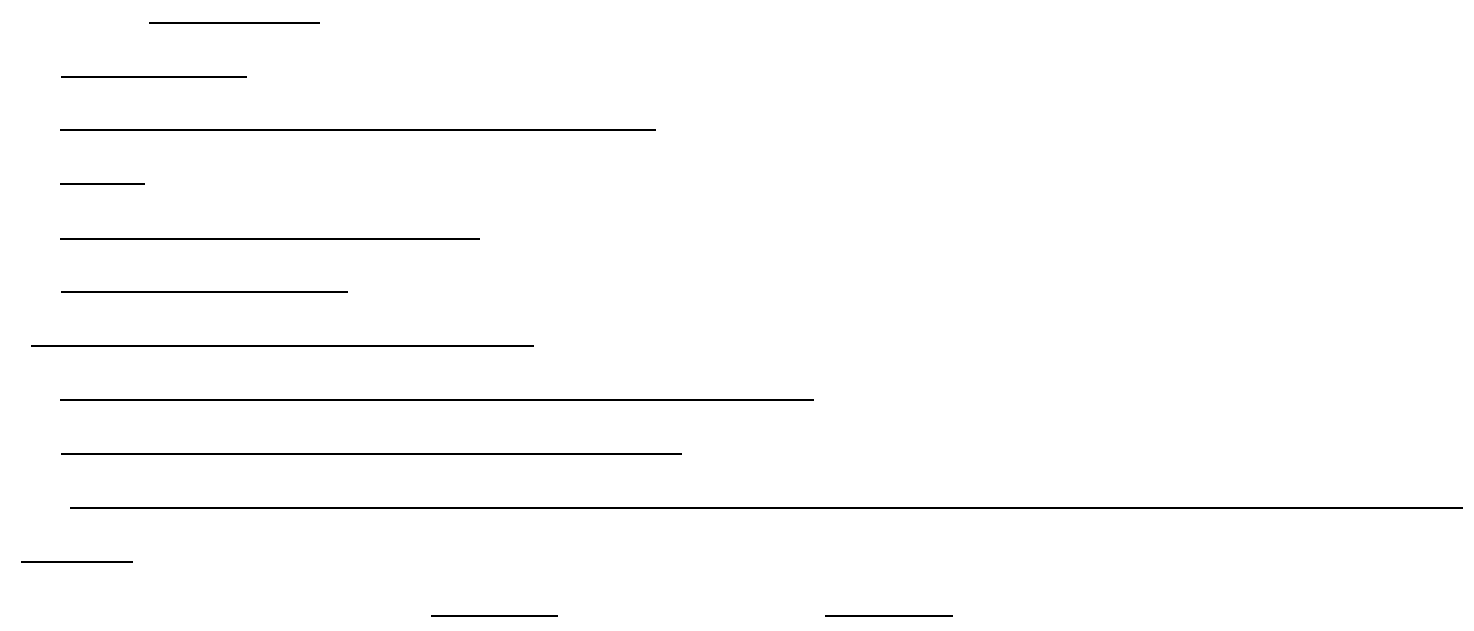




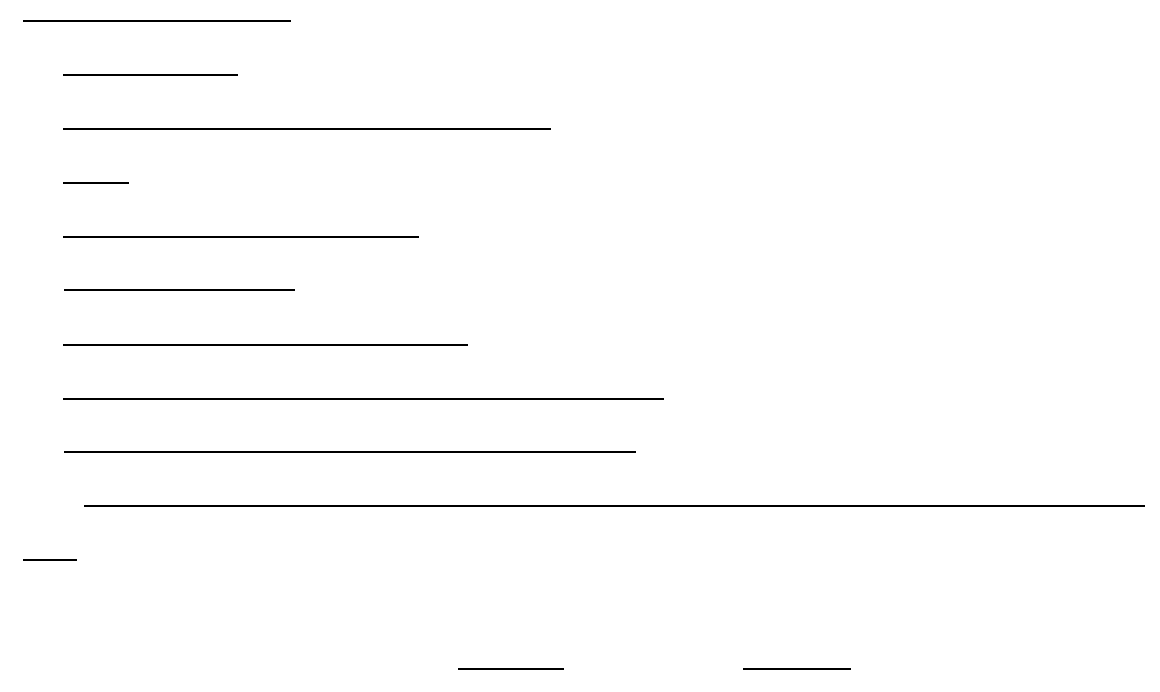

290 


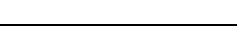

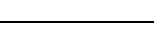




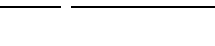



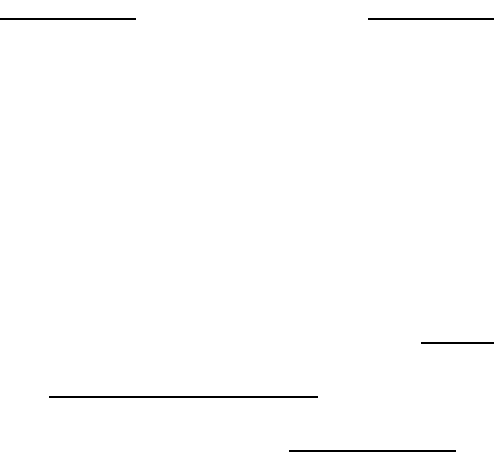

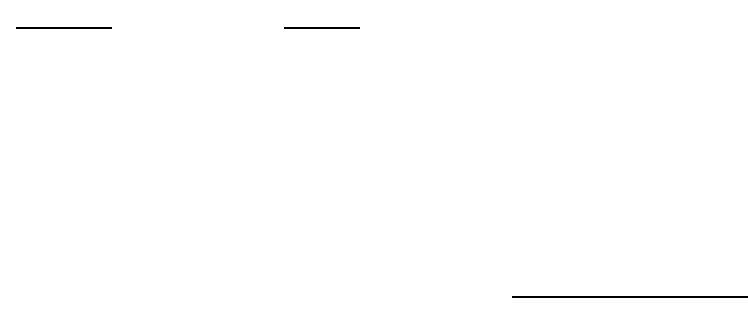

-

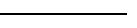




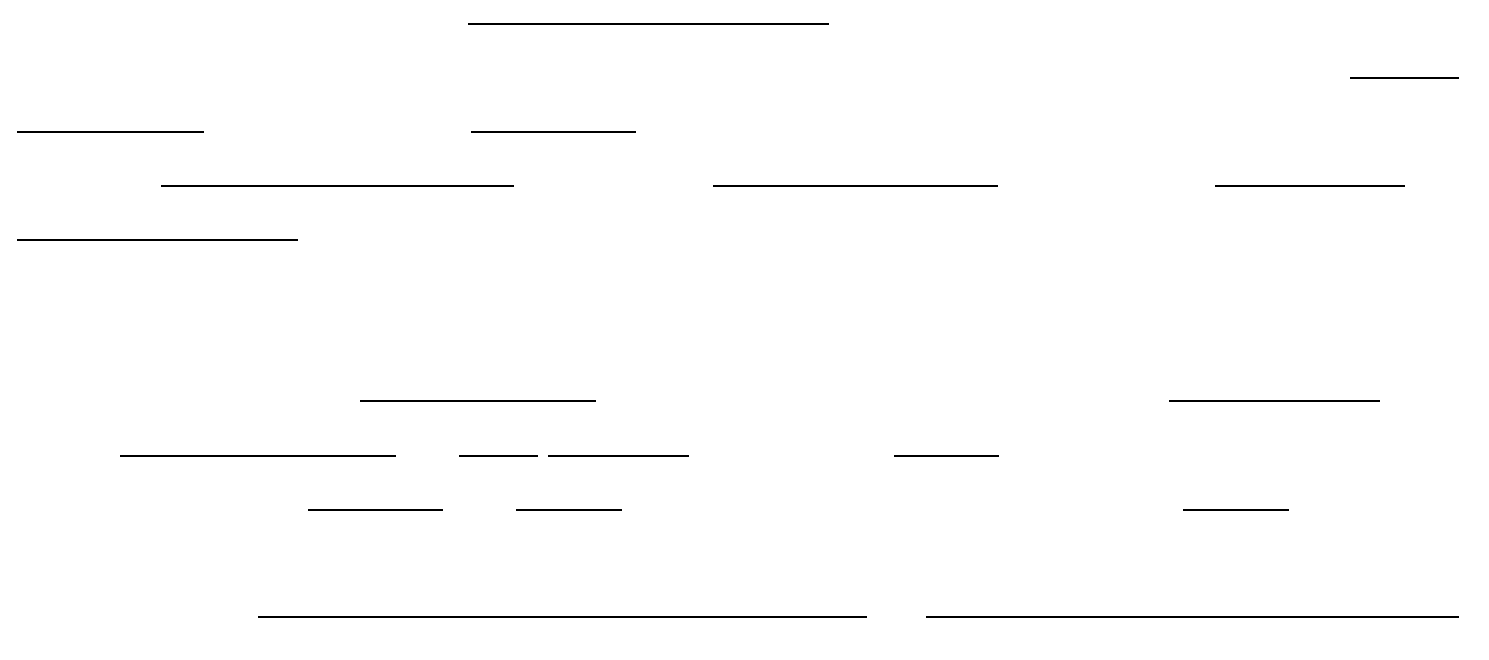




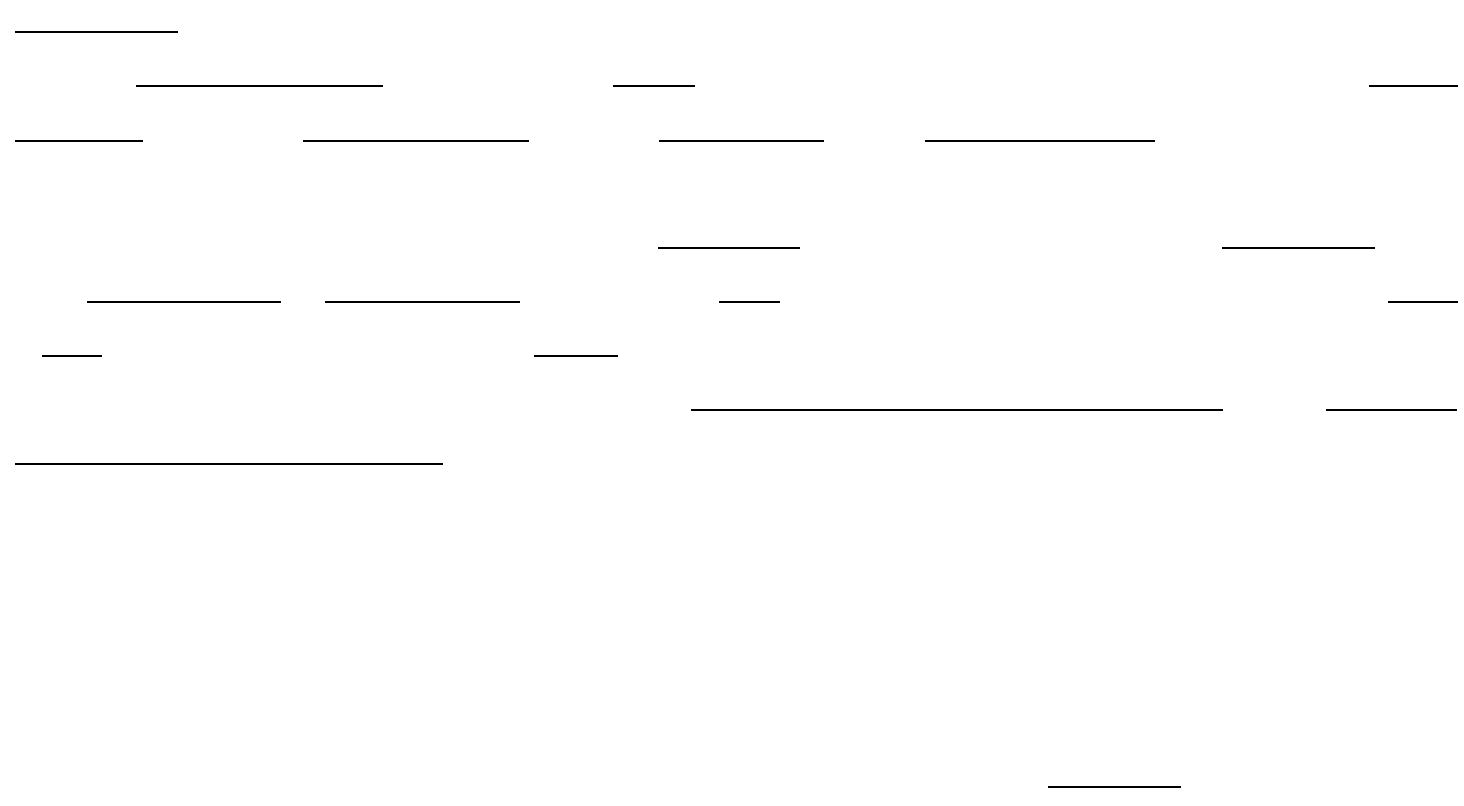


-

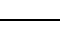


$-$

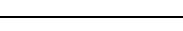




\title{
TRADUÇÃO COMENTADA DAS CARTAS
}

\author{
SEGUNDA PARTE \\ JUNHO — OUTUBRO DE 1967
}

Entre a primeira e a segunda parte das cartas, há uma pausa, devido ao encontro de Ungaretti e Bruna. Na primeira semana de abril de 1967, o poeta desembarca em Santos. Naquele período, há a entrega do título de doutor honoris causa e também a viagem a Salvador na companhia de Bruna. 
Ungaretti chega em São Paulo no dia 10 de outubro de 1967 e retorna à Itália no dia 2 de dezembro de 1967. Neste período, vai com Bruna à Argentina (Buenos Aires — para o prêmio Olivetti de literatura - e Bariloche) e depois ao Peru, onde recebe um segundo título de doutor honoris causa.

\section{TERCEIRA PARTE}

\section{DEZEMBRO DE 1967 - JANEIRO DE 1968}

A terceira parte de correspondência vai de dezembro de 1967 a janeiro de 1968.

Em janeiro de 1968, Bruna chega a Roma e permanece com Ungaretti até o final de março. Juntos, visitam a Alemanha e a Suíça, além de muitas outras cidades italianas, entre elas Trieste, Roma, algumas localidades na Sicília (junto com o pintor Cagli), Pompeia, Herculano, Capri, Nápoles, Crotone e Canelli — cidade da família de Bruna.

\section{QUARTA PARTE}

$$
\text { MARCO A AGOSTO DE } 1968
$$

A quarta parte de correspondência vai de março de 1968 a agosto de 1968.

No final de agosto de 1968, Bruna viaja à Itália acompanha Ungaretti até a Suíça e Paris, onde conhece Paulhan. Volta ao Brasil por volta do dia 10 de outubro de 1968.

Esse será o último encontro entre Ungaretti e Bruna.

\section{QUINTA PARTE}

OUTUBRO DE 1968 - ABRIL DE 1969

A quinta e última parte das cartas vai de outubro de 1968 a 14 de abril de 1969, quando Bruna recebe a última carta de Ungaretti.

No Natal de 1969, Bruna recebe um exemplar da edição de luxo do livro Il Dolore, de Ungaretti, com as seguinte dedicatória: "Para Bruna inesquecível/ Bom Natal/ Bom Ano/ Ungà", na segunda página branca do livro, continua: "Meu amor por ti / arde sempre, sob as cinzas/ Ungà/ Roma dia 6/XII/ 1969". 
Entre dezembro de 1969 e janeiro de 1970, Bruna telefona para Ungaretti perguntando por que ele não respondia às suas cartas. $O$ poeta responde perguntando quais cartas, pois não havia recebido a correspondência de Bruna. Em seguida, viajará para Nova Iorque e Oklahoma, e convida Bruna para que o acompanhe aos EUA. Ela, porém, declina o convite. 



\section{CONSIDERAÇÕES FINAIS}

QUALE PIETÀ?

\section{A Giuseppe Ungaretti}

Sono anch'io una donna ferita

esiliata tra gli nomini

come tutte le donne

\author{
Quale pietà? \\ Di te porto non la furia \\ ma le briciole di pane sulla finestra \\ distraevi dalla morte tuo figlio \\ con il volo dei passeri \\ incarnare l'occhio che sul muro \\ osserva il silenzio del gatto \\ del mondo e dell'anima \\ percorrere le periferie \\ nel verde vedere il segno \\ degli alberi di dentro \\ ingarbugliato barocco \\ di sangue e di linfa \\ essere la semantica della foresta \\ rifare il giorno \\ con una manciata d'ironia \\ e le mani sporche della poesia \\ [Francesca Cricelli, \\ 7 febbraio 2019]
}

QUAL PIEDADE?

A Giuseppe Ungaretti

Também sou uma mulher ferida

exilada entre os homens

como toda mulher

Qual piedade?

De ti levo não a fúria

mas as migalhas de pão no beiral da janela distraias da morte teu filho

com o voo dos pássaros

encarnar o olho que no muro

observa o silêncio do gato

do mundo e da alma

percorrer periferias

no verde ver o signo

das árvores de dentro

emaranhado barroco

de sangue e de seiva

ser a semântica da floresta

refazer o dia

com uma pitada de ironia

e as mãos sujas da poesia

[Francesca Cricelli,

7 de fevereiro de 2019] 

Neste estudo, procuramos oferecer a apresentação do descobrimento de um arquivo epistolar, sua descrição, seu recorte, algumas considerações sobre este gênero de escrita, tentando vincular nosso objeto de estudo a algo que se coloca no campo literário dentro da denominação do "espaço biográfico" descrito por Philippe LeJeune, com alguma tendência à natural autoficção quando se adentra o campo da escrita de si e da memória. Como observamos, guiados pelos estudos de Brigitte Diaz, a escrita de cartas é também uma manifestação da escrita de si, mesmo que num jogo de um diálogo entre ausências (Erasmo de Roterdã) - "por mais que o destinatário seja uma quimera ausente, é, apesar de tudo, estruturalmente indispensável ao aparecimento do sujeito em sua própria palavra". ${ }^{882}$ Dessa forma, tentamos observar como Ungaretti cria uma espécie de escuta privilegiada em sua interlocutora e, através dessa criação, pode tecer, amorosamente, relatos do seu cotidiano, das suas viagens, observações sobre composição poética, corrigir os poemas da jovem amada e criar, ele mesmo, novos poemas dedicados à interloucotra partindo de um estilo de tradução-apropriação de textos de outros poetas, como James Joyce, Al-Mutanabbi e Ibrahim Ibn Sahl, que decidimos, em parte, reler com a ajuda de Haroldo de Campos e seu filtro mefistofélico e plagiotrópico. Todos esses esforços caminharam no sentido de elucidar como a tradução em si é um gesto de crítica e organização, pois nossa análise nasce não só a partir da transcrição e organização das cartas cedidas por Bruna Bianco, mas também do nosso esforço em traduzi-las. Para a tradução, propomos uma cartografia para se navegar aquele amplo arquivo, com um recorte e uma leitura pessoal que privilegiaram as questões que tangenciavam a relação e a discussão a respeito da língua italiana e da linguagem, da criação poética, do vínculo com tradutores e traduções e, também, com artistas plásticos, bem com a vivência e o afeto nutrido pelos encontros com intelectuais, escritores e artistas brasileiros. Esse esforço de organização, discussão e tradução é um caminho que percorremos para observarmos nosso próprio fazer, deixando como pano de fundo - mas também como uma companhia silenciosa ao nosso lado — a pergunta sobre quais seriam as funções de um pesquisador que descobre um arquivo como esse, de certa forma, uma auto-análise: deveria o pesquisador também atuar como crítico e tradutor? É importante recordarmos aqui outra observação que guiou nosso esforço de seleção e

882 DIAZ, Brigitte. Op. cit., p. 163. 
tradução das missivas, ou seja, aquilo que Maurício Santana Dias relatou em entrevista à revista Belas Infiéis: "A tradução sempre se dá no tempo presente do tradutor" ${ }^{883}$

O pesquisador que trabalha com arquivos o faz como se respondesse a duas pulsões: uma externa, que é de busca por algum conhecimento fora de si, algo que está no mundo, alguma interpretação, alguma nova leitura de um fato ou de um texto a partir de documentos, relatos, fatos, manuscritos; outra interna, ou seja, uma pulsão que anima o desejo para a busca e a pesquisa externa. O desejo que moveu a pesquisadora para que se colocasse neste lugar. $\mathrm{O}$ trabalho com esse arquivo nasce, portanto, a partir do encontro dessas duas pulsões, desses dois estímulos. Por um lado, fomos atraídos pela curiosidade de descobrir algo novo a respeito da criação poética de Giuseppe Ungaretti, algo sobre os últimos anos de sua vida, para além daquilo que constava em suas publicações e sua ótima cronologia apresentada no volume crítico I Meridiani, da editora Mondadori; por outro, a esperança de que, nessas cartas, houvesse não só um vasto apanhado de declarações amorosas, mas algum signo daquele inexprimivel nada, daquele último segredo da poesia - daquilo que sempre nos escapa. Talvez uma das descobertas mais importantes, trazendo a público esse arquivo, é justamente - em nosso recorte — o uso da tradução para fertilizar a própria poesia, algo já observado na prática de Ungaretti, mas não com tamanha radicalidade como surge nas cartas entre o final de setembro de 1966 e o início de outubro do mesmo ano. Diálogos em tradução é um título que se inscreve justamente no sentido de pensar a dialógica ungarettiana em termos mais amplos: a partir do diálogo com Bruna, quais outros diálogos podem ser aferidos através das cartas? O arquivo agora é público, está aberto — tivemos o privilégio de trabalhar com ele quando ainda permanecia no âmbito privado da residência de Bruna Bianco — há uma publicação da transcrição completa em italiano. Portanto, o que tentamos apresentar aqui é um recorte, uma cartografia para a leitura a partir da nossa navegação. Seria possível traçar outras numerosas rotas, e tivemos que deixar para trás, por agora, algumas que ansiávamos navegar, mas tivemos de deternos diante do real e forjarmos um caminho que, de início, nos pareceu o mais apropriado: privilegiamos aprofundar a rota apontada. Ficará, para um futuro próximo, o desejo de escrever sobre as viagens de Ungaretti durante os anos dessa correspondência, tecer alguma observação entre sua descrição obsessiva de Salomé e a presença, constante, da mesma na literatura mundial.

Ao trabalharmos a seleção, tradução e organização das cartas, fomos atravessados como que por um pensamento silencioso que se deslocava, na memória, para o texto La carte postale, de Derrida, e suas perguntas — "Quem escreve? A quem? E para mandar,

883 PEREIRA, PILATI. Entrevista com Maurício Santana Dias. Belas Infiéis, v. 6, n. 2, p. 257-263, 2017. 
destinar, expedir o quê? A que endereço?" - mas também para outro texto seu, Mal de Arquivo: uma impressão freudiana. ${ }^{884}$ Nessa obra, Derrida explora tanto o duplo sentido da etimologia da palavra arquivo, arkhé, como origem e como comando, ou poder, mas também relaciona a noção de arquivo com a memória pessoal e histórica, fazendo tais considerações a partir de um episódio da vida de Freud narrado pelo historiador israelense Yosef Hayim Yerushalmi. Não vamos nos delongar muito aqui nos detalhes desse breve, porém rico e complexo, ensaio. Interessa-nos, aqui, apontar algumas ideias que surgem no texto para pensarmos nosso trabalho nesta tese. Derrida fala de impressão freudiana para pensar o arquivo no sentido de escritura e marca grafada: "Freud deixa marca a partir de uma impressão inscrita nele próprio, no sétimo dia de seu nascimento - marca de circuncisão; deixa esta impressão na história da psicanálise, na instituição Psicanálise e em suas obras, passando pela correspondência pública ou privada", 885 apontando para a dupla valência do arquivo, enquanto armazenamento preservado, mas também ao que chama de consignação, ou seja, "não basta o simples depósito em algum lugar". ${ }^{886}$ Usamos essa ideia aqui para pensar a obra de Ungaretti: por um lado, como tudo o que foi publicado e organizado pelo autor, por outro, sua extensa correspondência com outros autores; por último, este arquivo que, agora coordenado e reunido num único corpus, pede uma cartografia interpretativa. Porém, uma cartografia interpretativa para a navegação desse arquivo não significa uma única interpretação do mesmo, pelo contrário: aqui, apoiando-nos na ideia descontrutivista de Derrida, para afastar-nos desse mal de arquivo, não devemos nos deixar seduzir por uma pulsão de morte que "tende assim a destruir o arquivo hipomnésico, quando não disfarçálo, maquiá-lo, pintá-lo, imprimi-lo, representá-lo no ídolo de sua verdade em pintura" ${ }^{887}$ Assim como a tradução foi veículo de organização e estudo das missivas — o recorte surgiu enquanto traduzíamos, com uma preparação anterior, e, a priori, foi se delineando com o tempo a partir da própria tradução - e esta, como nos lembra novamente Maurício Santana Dias, “sempre se dá no tempo presente do tradutor”. Da mesma forma, nossa análise e nosso recorte, privilegiando uma interpretação do espaço biográfico e incursões autoficcionais, deslocando para a própria tese a ideia de arquivo, pois, além das

\footnotetext{
${ }^{884}$ Publicado na França, Mal d'Archive (DERRIDA, 1995) tem origem numa conferência pronunciada por Derrida em junho de 1994, em Londres, com um título distinto: "O conceito de arquivo. Uma impressão freudiana". Consultamos a edição brasileira (DERRIDA, Jaques. Mal de Arquivo. Uma impressão freudiana. [Traduzido por Claudia de Moraes Rego]. Rio de Janeiro: Relume Dumará, 2001.

885 SOLIS, Dirce Eleonora Nigro. Tela desconstrucionista: arquivo e mal de arquivo a partir de Jacques Derrida. Rev. Filos., Aurora, Curitiba, v. 26, n. 38, jan./jun. 2014, p. 379.

886 Ibid.

887 DERRIDA, Jaques. Mal de Arquivo. Uma impressão freudiana. Rio de Janeiro: Relume Dumará, 2001, p. 23.
} 
cartas de Ungaretti, anexamos dois documentos redigidios por Bruna Bianco e um testemunho, também dela.

Como nos ocupamos nessa tese não só da questão do papel do pesquisador que descobre um arquivo e como deveria mover-se a partir desse fato, mas também nos dedicamos a questões ligadas à prática da tradução, é importante retomarmos o que tentamos apresentar como tradução enquanto forma de crítica e organização do conhecimento, (na esteira de Campos, Berman e Levefere). No que diz respeito à organização do arquivo e sua tradução parcial, tentamos seguir o caminho apontado por Dias:

$[\ldots]$ ler minuciosamente esse texto buscando reconhecer nele suas estratégias retóricas para, em seguida a essa experiência, refletir sobre o melhor modo - melhor segundo minhas coordenadas culturais, minhas referências, meu contexto, minha subjetividade de leitor — de reescrevê-lo em minha língua. ${ }^{888}$

Cientes, ainda com Dias, de que "toda boa tradução parte necessariamente de um 'projeto" e de que o mesmo não deveria "se submeter a universais ou a conceitos apriorísticos sobre o que deva ser a tradução", ${ }^{889}$ tentamos abrir algumas perspectivas a partir de um recorte da bibliografia dos Estudos da Tradução, deixando-nos um amplo espaço para um embate com o texto selecionado e traduzido, tentando manter o próprio texto no centro do esforço da tradução e lançando mão de referências, dentro da própria obra do autor — seja poesia ou prosa crítica — para iluminar a intertextualidade presente no arquivo epistolar.

De alguma forma, também gostaríamos de pensar a questão levantada por Berman sobre a tradução enquanto albergue do longínquo em outros termos, ou seja, um albergue para o longínquo para além da palavra, para além de uma acomodação linguística do outro em nossa língua. É importante pensarmos essa questão para além do que seria um estranhamento literário em termos de uma obra traduzida, algo que vá ainda mais além de elementos intraduzíveis. Um arquivo epistolar já carrega em si algum estranhamento na própria natureza da sua escrita, mas há também uma postura de albergar o distante como uma

888 PEREIRA, Germana Henriques. PILATI, Alexandre. Entrevista com Maurício Santana Dias. Belas Infiéis, v. 6, n. 2, p. 257-263, 2017.

${ }^{889}$ Nos referimos aqui à resposta de Maurício Santana Dias na entrevista citada: "Penso que toda boa tradução parte necessariamente de um 'projeto'. Mas esse projeto, a meu ver, não pode de modo nenhum Não acho possível nem desejável que, durante o processo de tradução, se apliquem modelos teóricos, esta ou aquela abordagem. Dizendo de outro modo, a leitura da enorme bibliografia dos Estudos de Tradução é relevante para abrir as perspectivas do tradutor sobre sua experiência tradutória, mas seria deletéria caso restringisse seu campo de atuação e suas escolhas. O processo decisório deve ser o mais amplo e livre possível, e informado no embate do tradutor com o texto. Então os estudos no nosso campo, que tem autonomia própria e não deveria ser pensado como instrumental para tradutores, pode ampliar e afiar a reflexão do tradutor sobre seu ofício, e não servir como 'parâmetros regulares'. A consequência disso é que o projeto de tradução de cada texto irá se beneficiar de todas as referências culturais do tradutor, mas suas balizas serão dadas pelo próprio texto a ser traduzido.” (PEREIRA, Germana Henriques. PILATI, Alexandre. Entrevista com Maurício Santana Dias. Belas Infiéis, v. 6, n. 2, p. 257-263, 2017). 
ética. No caso dessas cartas, estamos tratando de um autor que sempre alimentou sua escrita no atravessamento biográfico, e aqui pudemos ver de perto outras nuances de seu processo criativo a partir de um encontro de amor. Porém, pensar o longíquo é também abrir a possiblidade de uma discussão sobre o destino e o devir dessa pesquisa, como também de outras: de que forma as instituições Universidade e Pesquisa podem aproximar-se de um exterior social, de um público leitor, de editoras, revisores e preparadores de texto; de que forma, em tempos tão graves, em que se teme, em nosso país, quanto à própria continuidade do ensino superior, podemos lançar uma ponte para cruzar o abismo — para usar a metáfora de Gauti Kristmannsson ${ }^{890}$ sobre o trabalho do tradutor — para nos aproximarmo de tal alteridade. A continuidade da pesquisa e do ensino depende também de apoio popular para que não sejamos tão longínquos em tempos de obscurantismo e retrocesso. Nesse sentido, a tradução é um dos mais importantes veículos que um povo pode ter em suas mãos como forma de resistência, tanto ao trazer para si o que é o Outro, quanto ao preparar o seu próprio repertório para ser lançado ao mundo. Ungaretti sempre teve plena consciência desse poder, e por isso traduziu e manteve laços estreitos com seus tradutores. Um amor demente, talvez, seja a ponte necessária para iluminar as trevas, atravessar abismos.

${ }^{890}$ KRISTMANNSSON, Gauti. Tradução, teorização e traição. Traduzido do islandês por Luciano Dutra, ainda inédito no Brasil (https://www.academia.edu/1933494/Gauti_Kristmannsson_Tradução_teorização_traição_Teor\%C3\%ADa_tryggð_og_túlkun_traduzido_do_islandês, consultado em 14 de abril de 2019). 



\section{APÊNDICE I}

Depoimento de Bruna Bianco enviado a mim por correio eletrônico com data de 2 de agosto de 2013

\section{LA MLA VTTA CON UNGÁ}

Stavo leggendo il giornale di mia abitudine "O ESTADO DE S.PAULO" e incontrai nel quaderno, dedicato alla letteratura, la foto di Ungaretti, con la notizia della sua visitazione alla città di S.Paulo. Il suo volto era aperto con un sorriso felice, bensí le spalle un pó curve al peso della saggezza. Da quell'istante fui posseduta d'una impazienza irrazionale, legando il mio pensiero al poeta per tutta la giornata. Avevo letto che si era ospitato al vecchio Cá d'Oro, alla Basilio da Gama, quando il centro della città di S.Paulo era ancora ospitale e in quel quartiere si erano fissati alcuni alberghi e negozi eleganti e tradizionali. Tra le migliori gioiellerie c'era H.Stern; delle calzolerie la Clark; pasticcerie Il Cristallo e la Dulca; sartorie di lusso e liberi profissionisti famosi. Siccome frequentavo il Cá d’Oro mi fu facilissimo sapere quando avrei trovato il Maestro: verso il mezzogiorno.

Alle undici del giorno seguente, venerdí del settembre 1966, bloccato il mio eccessivo pudore, e con in mano alcune poesie (a quell'età tutte le signorine un po' sciocche scrivevono poesia) mi diressi verso l'albergo. Quando arrivai Ungaretti non era ancora rientrato dai suoi impegni. Lo attesi impaziente, seduta su un sofá color chermesino, imbottito nel corridoio dell'unica entrata, potendo ovviamente controllare tutte le persone che arrivavano. L'amministratore dell'albergo, Edvino Prieth, che aveva un grande affetto per me, veniva ogni tanto a fare due chiacchere per calmare la mia ansia, che si faceva col fluire del tempo sempre più palese. Infine verso la mezza lo vidi arrivare. Varcò la soglia con l'impeto d'un ragazzino. L'accompagnava un apostolo con la pelle color panna, ancora più sbiadita dovuto all'abito colore blu cupo, il Prof.Italo Bettarello. Mi presentai. Si sedette con me sul divano. Gli misi tra le mani la busta con le poesie e balbettai qualcosa a riguardo, che già non aveva peso. Importante era quello che mi stava raccontando, con l'impeto di una cascata, seduto al mio fianco. Il contatto era caldo. Dopo alcuni istanti tutto il mio essere era in fiamma; sentivo il mio volto febbricitante. Ero euforica giacché Unga', così si era giá presentato e desiderava essere chiamato, mi parlava di cose bellisime, come se ci conoscessimo da tantissimo tempo, come se fosse sempre stato presente nella mia vita. Poi mi invitò a colazione. Siccome cominciavo a sentirmi a disagio per l'emozione rifiutai. Mi chiese il mio numero telefonico, informandomi che era di partenza per Rio all'incontro di amici, e anche di Vinicius de Moraes. Dopo una settimana circa, di ritorno a S.Paulo mi avrebbe cercata per parlare delle mie poesie. Gli diedi il telefono del mio ufficio. 
Mi accompagnò alla porta e nel salutarmi mi cinse la vita, che svettò come un giunco liberato dalla stretta di dita chiuse a tenaglia. Unga' percepì la frustata del mio corpo. Me lo confermò tempo dopo, liberi ormai da ogni soggezzione.

Scappai via : ebbra, in stato di grazia. E, per la prima volta in vita mia, una persona era riuscita a incidersi nella mia memoria, rimanendo presente sempre. Ogni altro pensiero era sovrapposto a quello di pensarlo. Ero assente, nessuno mai aveva sconvolto la mia emozione. Stavo bene e allo stesso tempo stavo male. Sentivo in me una gioia di ricchezza infinita e la sua non piú presenza mi faceva provare per la prima volta la solitudine. In ufficio, e poi piú tardi a casa, ero lontana, ritornavo ripetutamente alla scena, seduta sul divano del Cá d'Oro, vicinissima a lui e, tutte le volte che pensavo sentivo lo stesso piacere, intensissimo, tanto fisico come emozionale. E lo stesso piacere lo sento ora mentre lo stó per l'infinitesima volta rammentando.

Portavo con me un grande segreto : l'aver sentito, per la prima volta, quel dolce piacere dell'amore, che veste tutto il corpo di gioia che solo l'innamoramento permette. Finalmente provavo quel rapimento d'amore, le cui dimensioni mi erano state trasmesse solo da racconti d'amore o da film.

Ora anch'io lo provavo e per la prima volta mi sono sentita donna, femmina. E tutta presa a quel momento presente non pensavo a null'altro; non ero in condizione di pensare alla possibilitá futura che quell'incantesimo potesse continuare. Ero stregata, ero felice e in questo stato di alienazione continuavo a spingere il tempo, dal momento presente, verso il dopo, senza pronosticare da durata di questo sogno, che per me aveva già le dimensioni dell'eterno.

Era l'epoca dei capelli lughi, lisci e cotonati. I miei, essendo ricci, dovevano ricevere certe attenzioni dalla parrucchiera. Dopo lavati erano pettinati, girando tutt'attorno al capo, appiccicandoli con della lacca giapponese. Si doveva poi restare durante ore con la testa a uovo, e per evitare il ridicolo estetico si usava un foulard a turbante. Ero andata quel martedì mattina, come d'abitudine, dalla mia parrucchiera per il rituale indicato e per la manicure.

Arrivai in ufficio verso le 9,30. La mia segretaria mi venne incontro informandomi che dal Cá d'Oro mi avevano telefonato con insistenza. Mentre ricevevo questo messaggio mi stavano di nuovo richiamando al telefono dall'Albergo.

Al telefono c'era Ungá, che mi spiegava, che aveva antecipato il suo rientro a S.Paulo, giacché aveva urgenza di parlarmi, che stava aspettandomi e che voleva vedermi subito.

Durante i lunghissimi 15 minuti di taxí per arrivare all'albergo, strappai il turbante e sciolsi i capelli. Dentro di me la gioia mi stava ubriacando, ma invece di abbioccarmi, il mio corpo acquistava il vigore di un "mustang". 


\section{APÊNDICE II}

Carta de comprometimento e cessão das cartas para fins de estudo assinada por Bruna Bianco

(documento suprimido por conter material sigiloso) 



\section{APÊNDICE III}

Carta de Telavive

(imagens suprimidas por conter material sigiloso - fotografias de alguns manuscritos) 



\section{BIBLIOGRAFIA}

(a) Obras de e sobre Giuseppe Ungaretti

BARONCINI, Daniela. Ungaretti barocco. Roma: Carocci Editore, 2008.

BIZZARRI, Edoardo. UNGARETTI, Giuseppe. Cartas/Lettere 1966/67. Org. e trad. Cricelli, Francesca. São Paulo: Scriptorium, 2013.

CANDIDO, Antonio. Ungaretti em São Paulo. Estud. av. Vol. 8. N. 22. São

Paulo, Sept./Dec. 1994 (http://www.scielo.br/pdf/ea/v8n22/25.pdf, consultado em 12 de agosto de 2015).

CARBONCINI, Anna. Il carteggio Ungaretti-Bruna Bianco. In Quaderni. Nuova serie, n. 8, maggio 1999, Istituto Italiano di Cultura, São Paulo.

DAL BO, Federico. Tradurione come poesia: Bachmann e Celan interpreti di Ungaretti. In Traduzione e poesia nell'Europa del Novecento. A cura di Anna Dolfi. Roma: Bulzoni, 2004, p. 447-470.

DAMIANO, Enza. Due lingue in una voce sola. Ingeborg Bachmann traduce Giuseppe Ungaretti (https://www.academia.edu/5688154/Due_lingue_in_una_voce_sola_Ingeborg_Bachmann_traduce_Giuseppe_Ungaretti, consultado em novembro de 2018).

DELLA GIOVANNA, Ettore. Incontro con Giuseppe Ungaretti . Rai, 1961. https://www.youtube.com/watch?v=4qbNPMT915A [visitado em 14/04/2019].

GARAMPI, Silvia. Varianti d'autore negli epistolari: il caso Ungaretti. I cantieri dell'italianistica. Ricerca, didattica e organizzazione agli inizi del XXI secolo. Atti del XVII congresso dell'ADI - Associazione degli Italianisti (Roma Sapienza, 18-21 settembre 2013). A cura di B. Alfonzetti, G. Baldassarri e F. Tomasi. Roma: Adi editore, 2014 $<$ http:/ / www.italianisti.it/Atti-di- Congresso?pg $=$ cms\&ext $=$ p\&cms_cod$\mathrm{sec}=14 \& \mathrm{cms} \_$codcms $=581>$ [consultado em 20/06/2018].

GRASSO, Sebastiano. Ungaretti e Bruna Bianco: M'illumino d'amore. Pen Club Italia, setembro de 2013.

IEB. Paulo Emílio encontra Giuseppe Ungaretti, IEB, $2016<$ https://www.you-

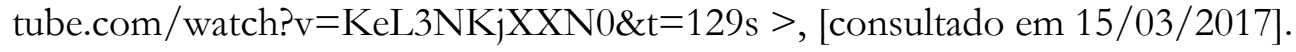

LANCIANI, Giulia. Org. Il Brasile di Ungaretti. Roma: Istituto Poligrafico e Zecca dello Stato, 2003.

LISBOA, Herniqueta. Vigília Poética. Belo Horizonte: Imprensa Publicações, 1968.

MADESANI, Angela. Ungà. Giuseppe Ungaretti e l'arte del XX secolo. Busto Arsizio: Nomos Edizioni, 2014. 
MARIANNI, Ariodante. Modelli arabi e joyciani di Ungaretti. Belfagor. Vol. 35, No. 2 (31 MARZO 1980), p. 198-202.

MASSI, Augusto. As passagens brasileiras. Folha de São Paulo, 21 de julho de 1996. , Augusto. O leão na sala de aula. Folha de São Paulo, 21 de julho de 1996. , Augusto. A paixão do mestre Ungà. Folha de São Paulo, 21 de julho de 1966.

MONTEFOSCHI, Paola. Ungaretti Le Eclissi della Memoria. Napoli/Roma: Edizioni Schientifiche Italiane, 1988.

OSSOLA, Carlo. Ungaretti, Poeta. Venezia: Marsilio, 2016.

PETRUCCIANI, Mario. Il condizionale di Didone. Napoli: Edizioni scientifiche italiane, 1985.

PICCIONI, Leone. Vita di Ungaretti. Milão: Rizzoli, 1979.

RAMAT, Silvio. Prefazione. In UNGARETTI, Giuseppe. Lettere a Bruna. Milão: Mondadori, 2017.

REBAY, Luciano. Le origini dela poesia di Giuseppe Ungaretti. Roma: Edizioni di Storia e Letteratura, 1962.

Luciano. Ungaretti lettere a Jone, Prima poesia per Jone, Canto a due voci per Jone. Revue des Études Italiennes. Nouvelle série. Tome 49. No. 1-2, Gen.-Giu. 2003.

, Luciano. Ungaretti: Lettere a Jone, Prima poesia per Jone, Canto a due voci per Jone. Forum Italicum, Anno 2004 - N. 1 - Pag. 45-65.

SANAVIO, Piero. Sulla lettera di Giuseppe Ungaretti. Reti di Dedalus, rivista del sindicato degli scrittori. http://www.retididedalus.it/Archivi/2014/dicembre/LUOGO_COMUNE/4_querelle/querelle.pdf. [consultado em 5/01/2015 e 8/11/2018].

Una corrisponden₹a: Dialogo Ungaretti- Bianco. Revista Malacoda.

https://malacoda4.webnode.it/una-corrispondenza-dialogo-ungaretti-bianco/ [consultado em 14/04/2019].

SIELO, Francesco. Ungaretti e l'arte informale: l'ossessione apocalittica della materia. La letteratura italiana e le arti. Atti del XX Congresso dell'ADI - Associazione degli Italianisti (Napoli, 7-10 settembre 2016). A cura di L. Battistini, V. Caputo, M. De Blasi, G. A. Liberti, P. Palomba, V. Panarella e A. Stabile. Roma: Adi editore, 2018 (http:/ /www.italianisti.it/Atti-diCongresso?pg $=$ cms\&ext=p\&cms_cod$\mathrm{sec}=14 \& \mathrm{cms} \_$codcms $=1039$ [consultado em 10/12/18].

UNGARETTI, Giuseppe. Invenzione della Poesia Moderna: Lezioni Brasiliane di Letteratura (1937-1942). Napoli: Edizioni Scientifiche Italiane, 1984. 
Giuseppe. Invenção da poesia moderna: lições de literatura no Brasil, 1937-1942. Estab. text. Paola Montefoschi. Trad. Antônio Lázaro de Almeida Prado. São Paulo: Ática, 1996.

, Giuseppe. Vita d'un uomo. Tutte le poesie. Milano: Mondadori, 2009.

Mondadori, 2010.

Giuseppe. Vita d'un uomo. Traduzioni poetiche. Milano:

(1974) 2001.

Giuseppe. Vita d'un uomo. Saggi e Interventi. Milano: Mondadori,

, Giuseppe. Vita d'un uomo. Viaggi e Lezioni. Milano: Mondadori,

2000.

Giuseppe. Daquela estrela à outra. Org. Lucia Wataghin. Trad. Haroldo de Campos e Aurora Fornoni Bernardini. São Paulo: Ateliê Editorial, 2003.

Giuseppe. La Luce. Artphilein Artist's Book: La Luce < https://vi-

meo.com/53155658 > [consultado em 14/04/2019].

Giuseppe. Lettere a Bruna. Milão: Mondadori, 2017.

Giuseppe. L'allegria è il mio elemento. Org. Silvia Zoppi Garampi.

Milano: Mondadori, 2013.

, Giuseppe. Invenzione della poesia moderna: Lezioni Brasiliane

(1937-1942). A cura di MONTEFOSCHI, Paola. Napoli: Edizioni Scientifiche Italiane, 1984.

WATAGHIN, Lucia. Ungaretti entre Oswald de Andrade, Blaise Cendrars, Haroldo de Campos: afinidades e assimetrias. Remate de Males. Campinas-SP, v. 37, n. 2, p. 971-984, jul./dez. 2017.

Giuseppe Ungaretti: Idee su poesia e tradurione. Libri e Riviste d'Italia.

La traduzione Saggi e Documenti II. Supplemento al N. ${ }^{\circ}$ 535-538 (settembre-dicembre 1994). Ministero per i beni culturali e ambientali: Roma.

Um mito tupi tradurido por Giuseppe Ungaretti: "Mai Pituna Oinquau

Ana" (“Como a Noite Apareceu”). Revista USP. São Paulo, no 37: 168- Março/Maio, 1998.

\section{(b) Epistolografia}

ANGELIDES, Sophia. Carta e Literatura: correspondência entre Tchekhov e Gorki. São Paulo: Edusp, 2001.

BACHMANN, Ingeborg. CELAN, Paul. Troviamo le parole. Lettere 1948-1973. Roma: Nottetempo, 2010.

DIAZ, Brigitte. Gênero epistolar O pensamento nômade. São Paulo: Edusp, 2016. 
EDITOR, O. Sobrescrito. Teresa, n. 8-9, p. xi-xi, 18 dez. 2008.

GUIMARÃES, Julio Castañon. Contrapontos: notas sobre correspondência no modernismo. Rio de Janeiro: Fundação Casa de Rui Barbosa, 2004.

KAUFMANN, Vincent. L'equivoque epistolaire. Paris: Les éditions de minuit, 1990. Post Scripts: The Writer's Workshop. Trad. ing. Deborah

Treisman. Cambridge (Massachusetts)/Londres: Harvard University Press, 1994.

LEJEUNE, Philippe. O pacto autobiográfico de Rousseau à Internet. Belo Horizonte: Editora UFMG, 2008.

MONTALE, Eugenio. Lettere a Clizia. Milano: Arnoldo Mondadori, 2009.

MORAES, M.A. NEVES, R.J. Apresentação do Dossiê Artífices da correspondência. Revista do Instituto de Estudos Brasileiros, n. 67, p. 103-105, 31 ago. 2017.

PAGÈS, A. A materialidade epistolar. O que nos dizem os manuscritos autógrafos. Revista do Instituto de Estudos Brasileiros, n. 67, p. 106-123, 31 ago. 2017.

PIRANDELLO, Luigi. Lettere a Marta Abba. A cura di Benito Ortolani. Milano: Mondadori, 2013, col "Meridiani".

SANTIAGO, Silviano. Suas cartas, nossas cartas. In: Ora (direis) puxar conversa! Belo Horizonte: Ed. UFMG, 2006.

TIN, Emerson (org.) A arte de escrever cartas. Campinas: Editora da Unicamp, 2005.

\section{(c) Estudos da tradução}

ARROJO, Rosemary. Tradução, Desconstrução e Psicanálise. Rio de Janeiro: Imago, 1993.

AUBERT, Francis. As (in)fidelidades da tradução: servidões e autonomia do tradutor. Campinas: Editora da Unicamp, 1986.

A tradução e a letra, ou, $O$ albergue do longínquo.

Trad. Marie-Heléne Catherine Torres, Mauri Furlan e Andréia Guerini. Rio de Janeiro: 7Letras/PGET, 2007.

BENJAMIN, Walter. Il compito del traduttore. In: Angelus Novus. Torino: Einaudi, p. 39-52, 1995.

rino: Einaudi, 1995, p. 53-70.

Sulla lingua in generale e sulla lingua dell'nomo. In: Angelus Novus. To-

BERMAN, Antoine. A Prova do Estrangeiro. Trad. Maria Emília Pereira Chanut.

Bauru/São Paulo: Edusc, 2002. 
CAMPOS, Haroldo de. Da tradução como criação e como crítica. In: Metalinguagem e outras metas. São Paulo: Perspectiva, 1992.

. Transcriação. São Paulo: Perspectiva, 2013.

. Da tradução como criação e como crítica. In Haroldo de Campos

Transcriação. Org. Marcelo Tápia e Thelma Médici Nóbrega. São Paulo: Perspectiva, 2015, p. 1-18.

. Transluciferação Mefistofáustica. In Deus e o Diabo no Fausto de

Goethe. São Paulo: Perspectiva, 1981.

CASSIN, Barbara. Après Babel, traduire. Actes Sud Beaux Arts Hors collection. Paris: Décembre 2016. < https://www.actes-sud.fr/catalogue/musees-collections-expositions/apres-babel-traduire $>$ [consultado em 14/04/2019.]

Dictionary of Untranslatables: A Philosophical Lexicon. Trad.

ing. Steven Rendall, Christian Hubert, Jeffrey Mehlman e Nathanael Stein. Princeton: Princeton University Press, 2014.

Éloge de la traduction: compliquer l'universel. Paris: Fayed, 2016.

GALVÃO, Walnice Nogueira. GOTLIB, Nádia Batella (orgs.). Prezado senhor, Prezada Senhora. Estudo sobre cartas. São Paulo: Cia. das Letras, 2000.

- A margem da Carta. São Paulo, Universidade de São

Paulo, Revista manuscrita, n. 7, 1998, p. 50 (http://revistas.fflch.usp.br/manuscritica/article/view/882/799, consultado em 20 de dezembro de 2016).

GAUTI KRISTMANNSSON. Tradução, teorização e traição. Trad. do isl. Luciano Dutra (ainda inédito no Brasil) https://www.academia.edu/1933494/Gauti_Kristmanns-

son_Tradução_teorização_traição_Teor $\%$ C3\%ADa_tryggð_og_túlkun_traduzido_do_islandês> [consultado em 14/04/2019].

LAGES, Susana Kampff. Walter Benjamin: Tradução e Melancolia. 1. ed. São Paulo: Edusp, 2007.

LARANJEIRA, Mário. Poética da Tradução. São Paulo: Edusp, 2003.

LEFEVERE, André. Beyond the process: Literary translation in literature and literary theory. In Gaddis Rose, M. Translation Spectrum: Essays in Theory and Practice, Albany, NY: State University of New York Press, p. 52-59. 1981.

Translation, Rewriting and the Manipulation of Literary

Fame. Londres/Nova Iorque: Routledge, 1992.

EDUSC, 2007.

. Tradução e manipulação da fama literária. Bauru: Editora

MESCHONNIC, Henri. Poética do Traduzir. São Paulo: Perspectiva, 2010. 
MITTMANN, Solange. Notas do Tradutor e Processo Tradutório - Análise e Reflexão sob uma Perspectiva Discursiva. Porto Alegre: Editora da UFRGS, 2003.

MUNDAY, Jeremy. Introducing Translation Studies: theories and applications. Londres: 2001.

PEREIRA, PILATI. Entrevista com Maurício Santana Dias. Belas Infiéis, v. 6, n. 2, p. 257-263, 2017.

PESSOA, Davi. Terceira margem: testemunha, tradução. Florianópolis: Editora da Casa, 2008.

Experiência e reflexão: o discuso ambíguo em Grande Sertão: veredas e sua tradução italiana. Dissertação de mestrado. Universidade Federal de Santa Catarina. <http://bdtd.ibict.br/vufind/Re-

cord/UFSC_478f8cf87aca181962f17ed54866e73d > [consultado em 20 de junho de 2015].

STEINER, George. After Babel: Aspects of Language and Translation.

Londres/Oxford: Oxford University Press, 1998.

TÁPIA, Marcelo. O Eco Antropofágico: reflexões sobre a trasncriação e a metáfora sanguineo-canibalesca. In CAMPOS, Haroldo de. Transcriação. São Paulo: Perspectiva, 2015, p. 215-232.

VENUTI, Lawrence. The Translation Studies Reader. Londres/Nova Iorque: Routledge, 2004.

L'invisibilità del traduttore: una storia della traduzione.

Trad. it. M. Guglielmi, Roma: Armando Editore, 1999.

(d) Outros

AGAMBEN, Giorgio. O que é o contemporâneo? e outros ensaios. Trad. Vinícius Nicastro Honesko. Chapecó: Argos, 2009.

AGUSTONI, Prisca. A presença da poesia italiana em Ipotesi, de Murilo Mendes. Remate de Males. 32.1, Jan./Jun. 2012. Campinas.

. O diálogo hipotético de Murilo Mendes. Revista de Cultura Agulha.

N. 45. Fortaleza/São Paulo. Maio 2005.

AMOroso, Maria Betânia. Murilo Mendes o Poeta Brasileiro de Roma. São Paulo: Editora UNESP, 2013.

ANDRADE, Oswald de. Memorie sentimental di Giovanni Miramare. Tr. it. Giovanni Cutolo. Prefácio de Giuseppe Ungaretti. Milano: Feltrinelli, 1970.

BARTHES Roland. Frammenti di un discorso amoroso. Torino: Einaudi, 2001. 
Fragmentos de um discurso amoroso. Trad. Maria Valeria

Martinez de Aguiar. São Paulo: Martins Fontes, 2003.

BENJAMIN, Walter. A origem do drama barroco alemão. Trad. Sergio Paulo Rouanet. São Paulo: Brasiliense, 1984.

BLANCHOT, Maurice. O espaço literário. Rio de Janeiro: Rocco, 1987.

BONAMINIO, Vincenzo. Nas margens de mundos infinitos. Org. Ana Rita Nuti Pontes. Trad. Francesca Cricelli et. al. Rio de Janeiro: Imago, 2010.

BORGOGNO, Franco. Psicanálise como percurso. Trad. Marina Rossi. Rio de Janeiro: Imago, 2004.

BOSI, Alfredo. Dialética da colonização. São Paulo: Cia. das Letras, 2001.

BUCARELLI, Palma. Jean Fautrier: pittura e materia. Milão: Il Saggiatore, 1960.

BUTLER, Judith. Uma poética de não chegada. Trad. Tomaz Amorim Izabel. São Paulo, Cult, ed. 194 (http://revistacult.uol.com.br/home/2014/11/uma-poetica-da-nao-chegada/ [consultado em 7 de dezembro de 2016].

CAMPOS, Haroldo de. O sequestro do barroco. São Paulo: Iluminuras, 2011.

CICALINI, Giorgia. Palma Bucarelli e la Biennale di Venezia (1948-68): acquisizioni, prestiti e interventi critici della Direttrice della Galleria Nazionale d'Arte Moderna di Roma. 2015/2016. 156 pp. Tesi di Laurea — Università Ca'Foscari, Veneza, [s.d.] (http://dspace.unive.it/bitstream/handle/10579/9773/855482-1201030.pdf?sequence $=2$, [consultado em 10/01/2019].

COSTA, Horácio. Frente ao oráculo: Murilo Mendes escreve "Siciliana". Via Atlântica.

N. 15, 24 jun. 2006, p. 267-274.

COURI, Norma. La vita è così, maestro. Seção Despedida. Piauí. Ed. 30 (https://piaui.folha.uol.com.br/materia/la-vita-e-cosi-maestro/, consultado em 10/04/2019).

CRICELLI, Francesca. Repátria. São Paulo: Selo Demônio Negro, 2015.

DERRIDA, Jaques. Mal de Arquivo: uma impressão freudiana. Trad. Claudia de Moraes Rego. Rio de Janeiro: Relume Dumará, 2001.

DORAN, Michael. Cézanne Documenti e Interpretazioni. Bernard, Borély, Denis, Geffroy, Jourdain, Languier, Osthaus, Riviére, Schnerb, Vollard. Roma: Universale Donizzelli, 1998.

ECO, Umberto. Obra aberta: forma e indeterminação nas poéticas contemporâneas. Trad. Giovanni Cutolo. São Paulo: Perspectiva, 2001.

FREITAS NETO, Alípio Correia de. Uma nota irônica à terminologia feudal em James Joyce. Em Música de Câmara. Trad. e introd. Alípio Correia de Freitas Neto. São Paulo: Iluminuras, 1998. 
FUKS, Julian. História abstrata do romance, Tese de doutorado, FFLCH , USP: 2016 p. 132. < https://www.teses.usp.br/teses/disponiveis/8/8151/tde-14032017-

160249/publico/2016_JulianMiguelBarberoFuks_VOrig.pdf> [consultado em 14 de abril de 2019].

GROTSTEIN, James S. Quem é o sonhador que sonha o sonho? Um estudo de presenças psíquicas. Rio de Janeiro: Imago, 2003.

HANSEN, J. A. Barroco, neobarroco e outras ruínas. Teresa, n. 2, p. 10-67, 8 dez. 2001.

JEAN ABES, Gilles. Uma tradução de "crise de verso" de Mallarmé: a ótica do enigma como símbolo do texto literário. São Paulo, Universidade de São Paulo, TradTerm, n. 6, 2010, p. 149174.

LAGO, Eduardo. Anne Carson: "La gran paradoja es escribir con placer sobre algo trágico". EL PAÍS. 3 de maio de 2019 < https://elpais.com/cultura/2019/05/03/babelia/1556899710_745273.amp.html?_twitter_impression=true\&fbclid $=\mathrm{IwAR} 0 \mathrm{Z} 0 \mathrm{qcMcCriUbgERFr} 1 \mathrm{cv} 4 \mathrm{gF} 0 \mathrm{ImH} 2 \mathrm{~S} 0 \mathrm{CAvIBwYW}-$ msgwBBhFjhdKUW11NbQ> [consultado em 03/05/2019].

MACHADO, Lourival G. Barroco Mineiro. São Paulo: Perspectiva, 1969 (reed. 2003).

MENDES, Murilo. La finestra del caos. Trad. it. Giuseppe Ungaretti. Milano: All'insegna del pesce d'oro, 1961.

vatore Sciascia, 1959.

Siciliana. Trad. it. A.A. Chiocchi. Caltanissetta (Sicília): Editore Sal-

MIŁOSZ, Czesław. O testemunho da poesia: seis conferências sobre as aflições do nosso tempo. Curitiba: Editora UFPR, 2012.

MOURA, Murilo Marcondes de. O Mundo sitiado. A poesia brasileira e a Segunda Guerra Mundial. São Paulo: Editora 34, 2016.

MOLLOY, Sylvia. Viver entre línguas. Trad. Julia Tomasini e Mariana Sanchez. Editora Belo Horizonte: Relicários, 2018.

PETERLE, Patricia. No limite da palavra percursos pela poesia italiana. Rio de Janeiro: 7Letras, 2015.

POUND, Ezra. Ars Poetica: saggi letterari. Torino: Nino Aragno Editore, 2009.

Paulo: Cultrix, 2006.

O Abc da Literatura. Trad. Augusto de Campos e José Paulo Paes. São

RONDONI, Davide. Ungaretti e la verità in amore. Avvenire. (https:/ /www.avvenire.it/agora/pagine/ungaretti, [consultado em 17/09/2017].

L'amore non è giusto, Forlì: Carta Canta Editore, 2013.

SEBALD, W.G. Os emigrantes, São Paulo: Cia. das Letras : 1992. 
SOLIS, Dirce Eleonora Nigro. Tela desconstrucionista: arquivo e mal de arquivo a partir de Jacques Derrida. Rev. Filos., Aurora, Curitiba, v. 26, n. 38, p. 373-389, jan./jun. 2014.

WINNICOTT, D.W. Transitional objects and transitional phenomena. International Journal of Psychoanalysis, 34:89-97, (1953).

. Clinical varieties of transference. International Journal of Psycho-Analysis, 37, 386, (1955-6 
